\title{
Exogén SA kezelések fényben és sötétben történő hatásának összehasonlító elemzése vad típusú és etilén receptor mutáns, Never-ripe paradicsom növények leveleiben
}

\author{
Doktori (Ph.D.) értekezés
}

\section{Takács Zoltán}

Témavezetők:

Dr. Görgényi Miklósné Dr. Tari Irma

egyetemi docens

Dr. Poór Péter

egyetemi adjunktus

Biológia Doktori Iskola

Növénybiológiai Tanszék

SZTE TTIK

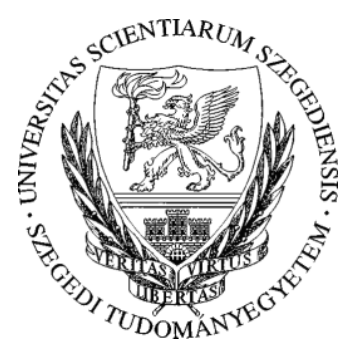

Szeged 


\section{Tartalomjegyzék}

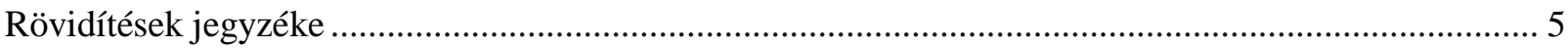

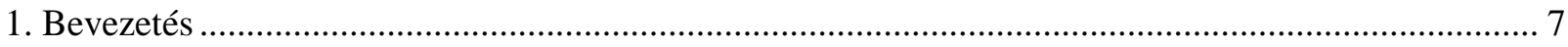

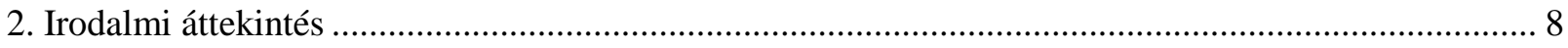

2.1. A biotikus stresszben szerepet játszó jelátviteli molekulák és enzimek ……................................ 8

2.1.1. A szalicilsav élettani hatása, bioszintézise és konjugációja...................................................... 8

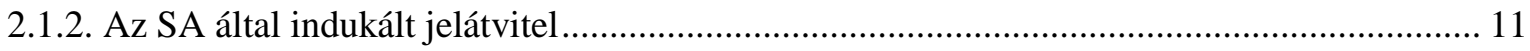

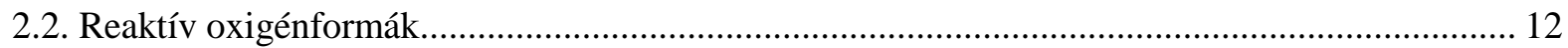

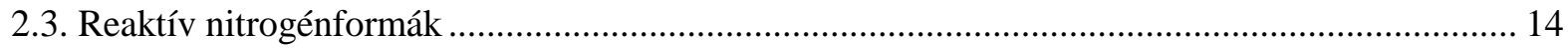

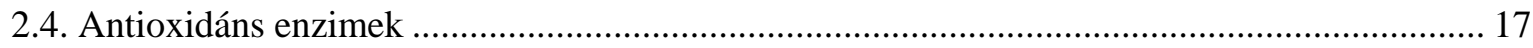

2.5. A poliaminok

2.5.1. A poliaminok szintézise és bioszintézisük szabályozódása növényekben.............................. 20

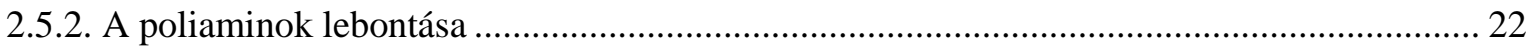

2.5.3. A poliaminok oxidatív és nitrozatív stresszben betöltött szerepe ………………................... 25

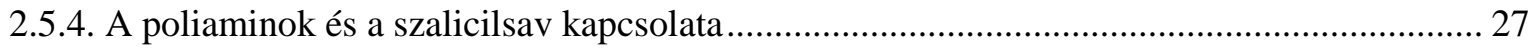

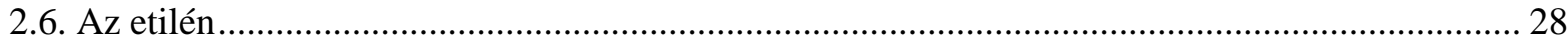

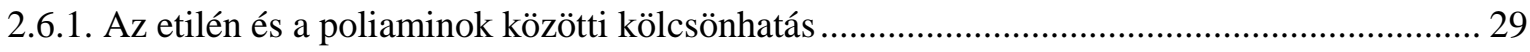

2.7. A fény és sötétség hatása a növények stresszfolyamatában szerepet játszó molekulákra ............ 30

2.7.1. Az SA és a fény/sötét kezelés kapcsolata ............................................................................. 31

2.7.2. A ROS, NO és a fény/sötét kezelés kapcsolata.................................................................... 31

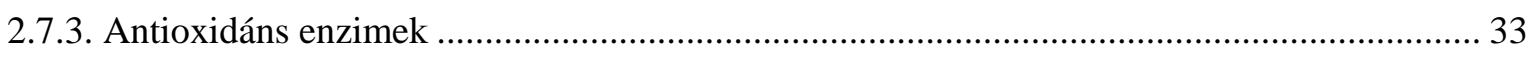

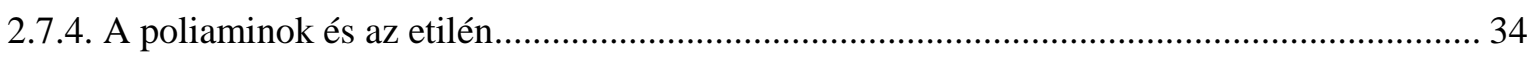

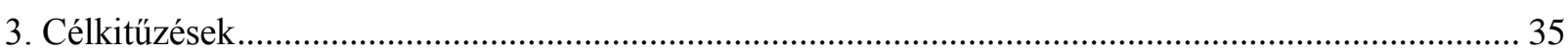

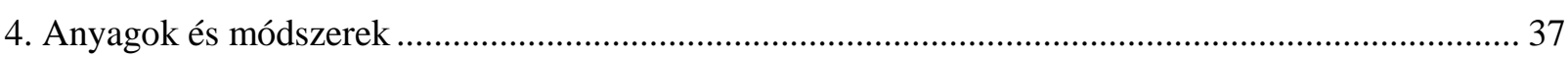

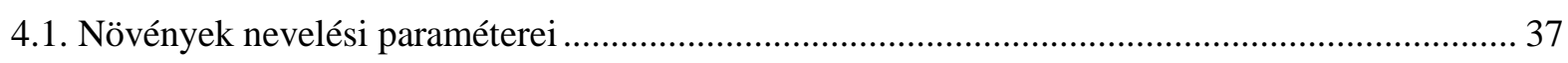

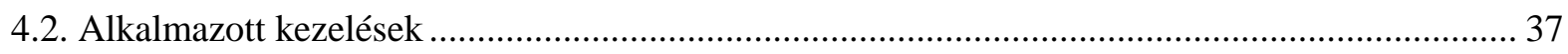

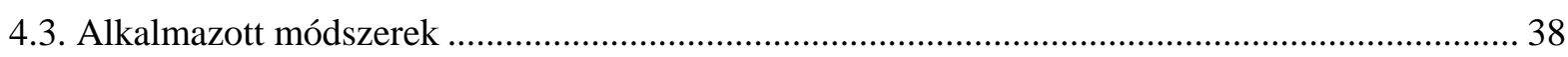

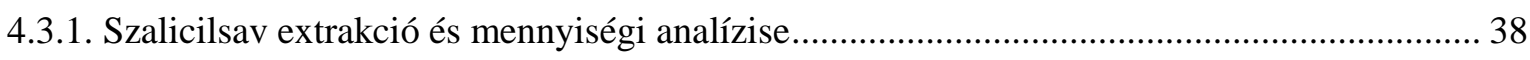

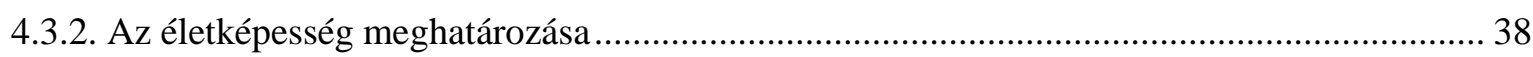

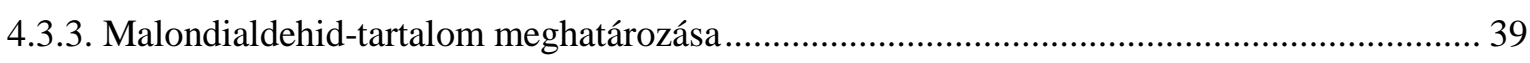

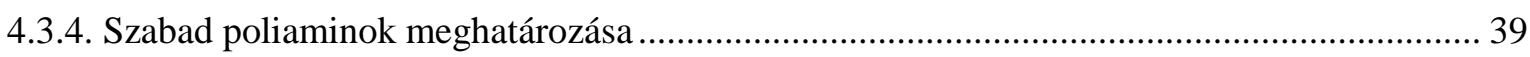

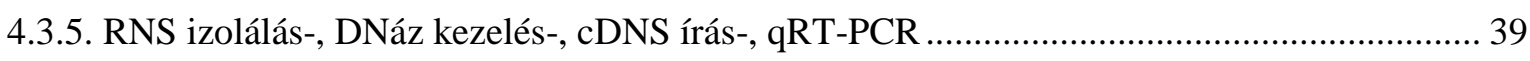

4.3.6. A poliaminok lebontásában szerepet játszó enzimek aktivitásának meghatározása ............... 41

4.3.7. A szuperoxid gyökanion kvalitatív meghatározása ................................................................. 41

4.3.8. Hidrogén-peroxid kvantitatív és kvalitatív meghatározása.................................................... 41

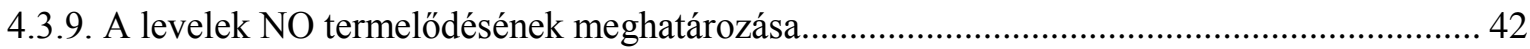


4.3.10. Az etilén termelődés meghatározása.

4.3.11. Antioxidáns enzimek és a NADPH-oxidáz aktivitásának vizsgálata.................................... 43

4.3.11.1. NADPH-oxidáz izoenzimek meghatározása............................................................... 43

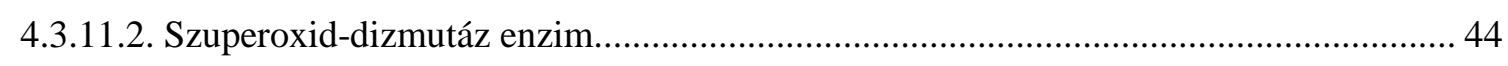

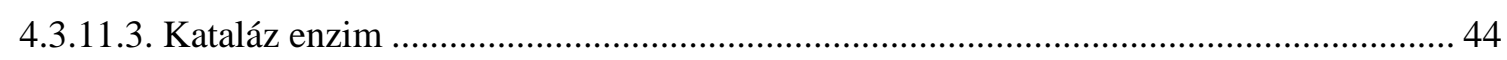

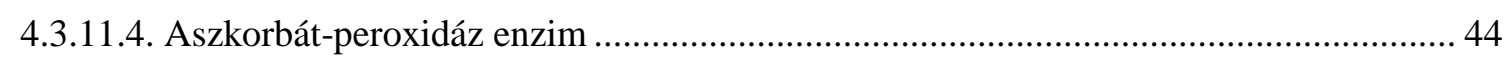

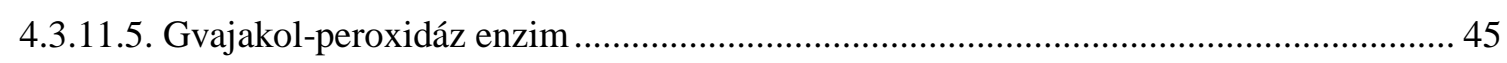

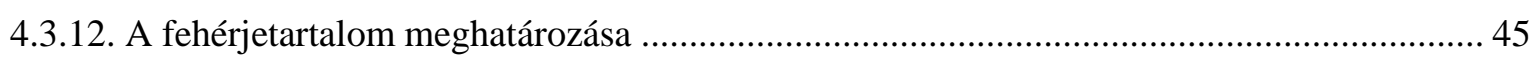

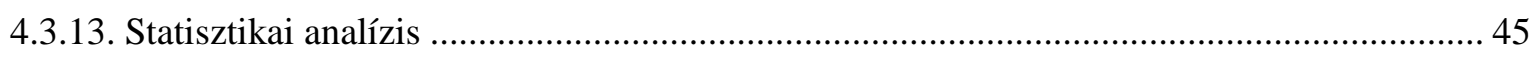

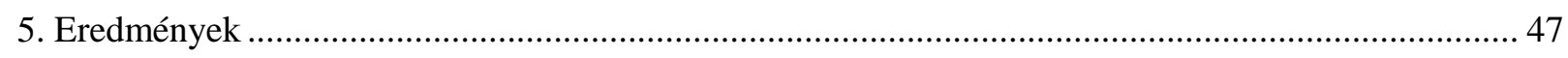

5.1. A különböző SA kezelések által indukált oxidatív stressz vizsgálata normál fotoperióduson, valamint sötétben kezelt vad típusú Ailsa Craig paradicsom növények leveleiben............................. 47

5.1.1. Az endogén szabad, kötött és összes SA tartalmak változásai ............................................ 47

5.1.2. A plazmamembrán integritásának és stabilitásának változása............................................. 48

5.1.3. A szabad poliaminok koncentrációjának változásai ........................................................... 50

5.1.4. A PA-ok bioszintézisében szerepet játszó enzimeket kódoló gének expressziójának

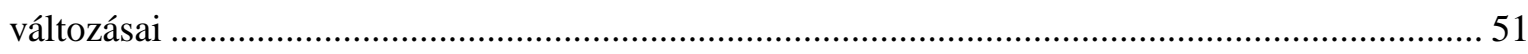

5.1.5. A PA-ok terminális lebontásában szerepet játszó enzimek aktivitásának és expressziójának

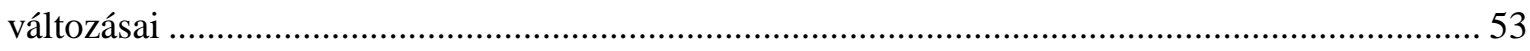

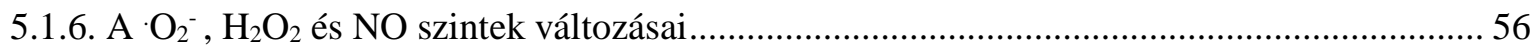

5.1.7. A NOX enzim aktivitása és az SIRBOH1 gén expressziója .................................................... 59

5.1.8. A szuperoxid-dizmutáz aktivitása és a különböző izoenzimeket kódoló gének expressziója 60

5.1.9. A kataláz aktivitása és a különböző izoenzimeket kódoló gének expressziója ....................... 62

5.1.10. Az aszkorbát-peroxidáz enzim aktivitása és a különböző izoenzimeket kódoló gének

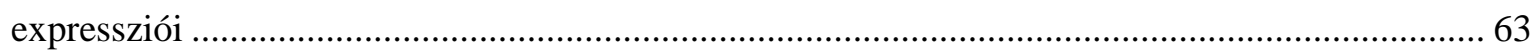

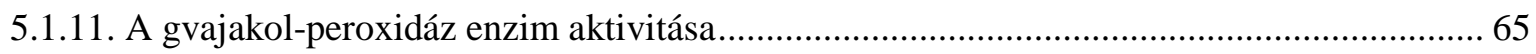

5.2. A különböző SA kezelések által indukált oxidatív stressz vizsgálata normál fotoperióduson, valamint sötétben kezelt etilén receptor mutáns, Never-ripe paradicsom növények leveleiben........... 66

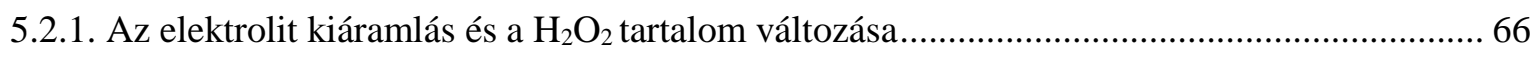

5.2.2. Az endogén szabad, kötött és összes SA tartalom változásai VT és $\mathrm{Nr}$ növények leveleiben68

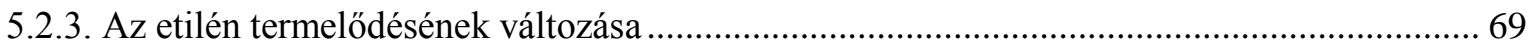

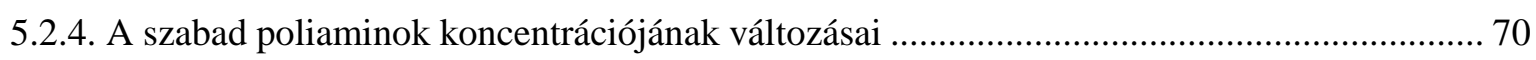

5.2.5. A PA-ok bioszintézisében szerepet játszó enzimeket kódoló gének expresszójának változásai

5.2.6. A PA-ok lebontásában szerepet játszó enzimek aktivitásának és gén expressziójának

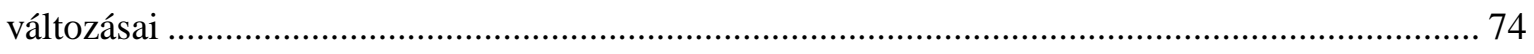

5.2.7. A szuperoxid-dizmutáz enzim aktivitása és az izoenzimeket kódoló gének expressziója..... 78

5.2.8. A kataláz enzim aktivitása és az izoenzimeket kódoló gének expressziója ............................ 81

5.2.9. Az aszkorbát-peroxidáz enzim aktivitása és az izoenzimeket kódoló gének expressziója .... 82 


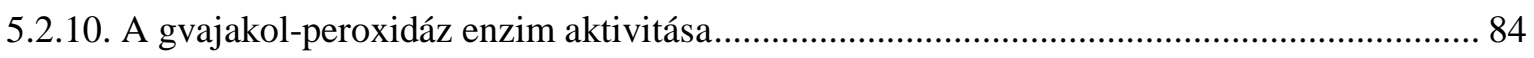

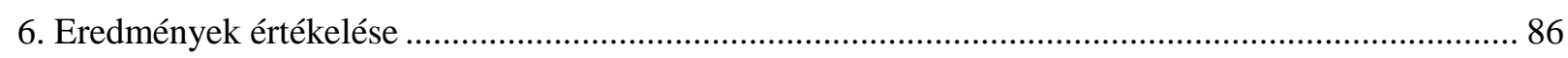

6.1. A normál fotoperióduson és sötétben történő SA kezelések hatása a vad típusú AC növények

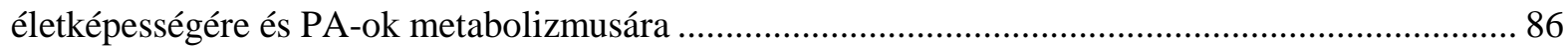

6.2. A normál fotoperióduson és sötétben történő SA kezelések hatása a vad típusú AC növények

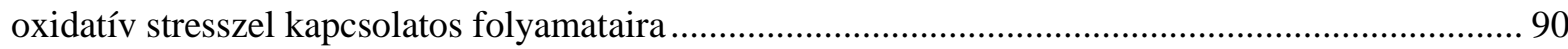

6.3. A normál fotoperióduson és sötétben történő SA kezelések hatása az etilén receptor mutáns, Never-ripe növények oxidatív stresszel kapcsolatos folyamataira .................................................... 95

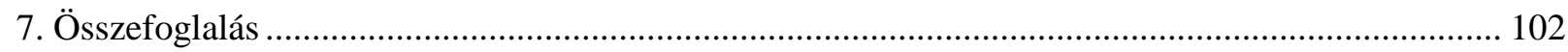

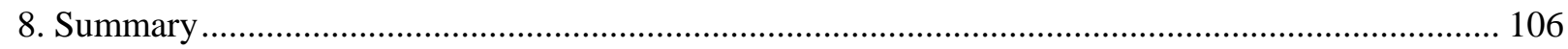

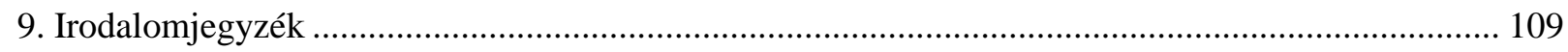

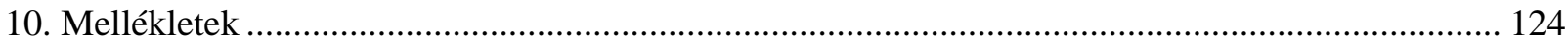

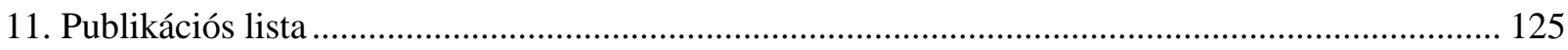

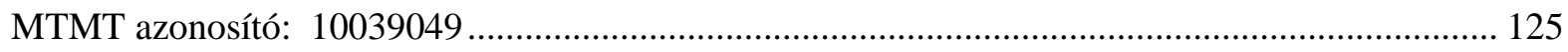

11.1. Tudományos közlemények referált folyóiratokban ................................................................ 125

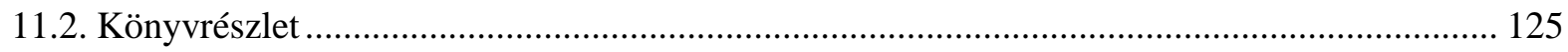

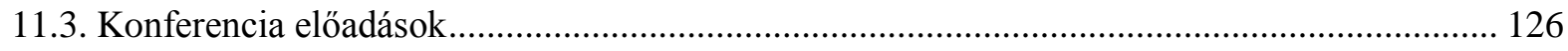

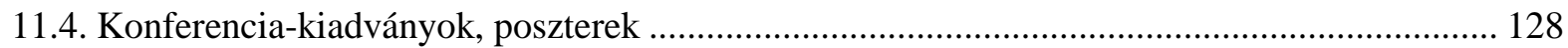

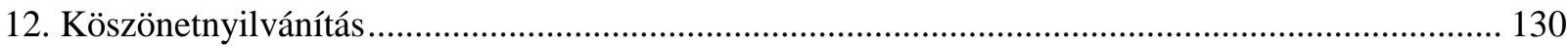

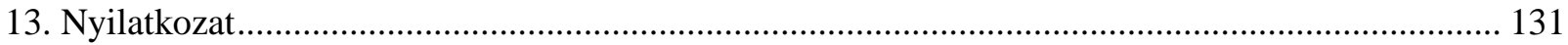




\section{Rövidítések jegyzéke}

\begin{tabular}{|c|c|}
\hline $\mathrm{AC}$ & Ailsa Craig paradicsom \\
\hline $\mathrm{ACC}$ & 1-aminociklopropán-1-karbonsav \\
\hline ACS & ACC szintáz (EC 4.4.1.14) \\
\hline $\mathrm{ACO}$ & ACC oxidáz (EC 1.14.17.4) \\
\hline $\mathrm{ADC}$ & Arginin-dekarboxiláz (EC 4.1.1.19) \\
\hline AGM & Agmatin \\
\hline $\mathrm{AIH}$ & Agmatin-iminohidroláz (EC 3.5.3.12) \\
\hline ASC & Aszkorbát (redukált) \\
\hline APX & Aszkorbát-peroxidáz (EC 1.11.1.11) \\
\hline ARG & Argináz (EC 3.5.3.1) \\
\hline BA & Benzoesav \\
\hline $\mathrm{Cu} / \mathrm{ZnSOD}$ & Réz/cink-szuperoxid-dizmutáz \\
\hline $\mathrm{DAB}$ & 3'3-diamino-benzidin \\
\hline DAF-FM-DA & 4-amino-5-metilamino-2',7'-difluorofluoreszcein-diacetát \\
\hline $\mathrm{DAO}$ & Diamin-oxidáz (EC 1.4.3.6) \\
\hline DAP & 1,3-diaminopropán \\
\hline dcSAM & Dekarboxilált S-adenozil-L-metionin \\
\hline EL & Ionkieresztés (electrolyte leakage) \\
\hline ER & Endoplazmatikus retikulum \\
\hline FeSOD & Vas-szuperoxid-dizmutáz \\
\hline FT & Friss tömeg \\
\hline $\mathrm{H}_{2}$ DCFDA & 2',7'-dikloro-dihidro-fluoreszcein-diacetát \\
\hline HPLC & $\begin{array}{l}\text { Nagy nyomású folyadékkromatográfia (High Pressure Liquid } \\
\text { Chromatography) }\end{array}$ \\
\hline HR & Hiperszenzitív reakció \\
\hline KAT & Kataláz (EC 1.11.1.6) \\
\hline MAPK & Mitogén-aktivált protein kináz \\
\hline MDA & Malondialdehid \\
\hline MeSA & Metil-szalicilsav \\
\hline MeSAG & MeSA $2-O-\beta$-D-glükozid \\
\hline $\mathrm{MES} / \mathrm{KCl}$ & 2-(N-morfolin)-etánszulfonsav/kálium-klorid \\
\hline MnSOD & Mangán-szuperoxid-dizmutáz \\
\hline NADPH-oxidáz & $\begin{array}{l}\text { Nikotinamid-dinukleotid-foszfát oxidáz } \\
\text { (plazmamembrán kötött) }\end{array}$ \\
\hline NBT & Nitrotetrazólium-kék \\
\hline NCPAH & N-karbomilputreszcin-amidohidroláz (EC 3.5.1.53) \\
\hline NO & Nitrogén-monoxid \\
\hline NOX & Plazmamembrán kötött NADPH-oxidáz \\
\hline NPR1 & Non-expressor of pathogenesis-related genes 1 \\
\hline $\mathrm{Nr}$ & Never-ripe (etilén receptor) paradicsom mutáns \\
\hline ODC & Ornitin-dekarboxiláz (EC 4.1.1.17) \\
\hline PA & Poliamin \\
\hline PAGE & Poliakrilamid-gélelektroforézis \\
\hline PAO & Poliamin-oxidáz (EC 1.5.3.3) \\
\hline PCD & Programozott sejthalál (Programmed Cell Death) \\
\hline PM & Plazmamembrán \\
\hline PMSF & Fenil-metil-szulfonil-fluorid \\
\hline POD & Gvajakol-peroxidáz (EC 1.111.7) \\
\hline
\end{tabular}


PR

PSI

PSII

Put

PVPP

qRT-PCR

Rboh

ROS

SA

SAG

SAM

SAMDC

SAMS

SAMT

SAR

SGE

SMO

SNP

SNAP

SOD

Spd

SPDS

Spm

SPMS

TCA

TMV

VT

Patogén kapcsolt gének/fehérjék (Pathogene related genes/protein)

Az első fotokémiai rendszer

A második fotokémiai rendszer

Putreszcin

Polivinil-polipirrolidon

Kvantitatív valós idejü polimeráz láncreakció

Respiratory burst oxidase homolog: növényi NOX

Reaktív oxigénformák (Reactive oxygen species)

Szalicilsav (Salicylic acid)

SA 2-O- $\beta$-D-glükozid

S-adenozil-L-metionin

S-adenozil-L-metionin-dekarboxiláz (EC 4.1.1.50)

S-adenozil-L-metionin-szintáz (EC 2.5.1.6)

SA karboxil-metiltranszferáz

Szisztemikus szerzett rezisztencia (Systemic acquired resistance)

SA-glükóz-észter

Spermin-oxidáz (állati)

Nátrium-nitroprusszid

S-nitrozo-N-acetil-DL-penicillamin

Szuperoxid-dizmutáz (EC 1.15.1.1)

Spermidin

Spermidin-szintáz (EC 2.5.1.16)

Spermin

Spermin-szintáz (EC 2.5.1.22)

Triklórecetsav (Trichloroacetic acid)

Dohány mozaik vírus (Tobacco Mosaic Virus)

Vad típus 


\section{Bevezetés}

A növényeket érintő stressztényezők közül az egyik legfontosabb a biotikus stressz, amelyet különböző élőlények úgy, mint baktériumok, gombák és fertőző ágensek (vírusok) válthatnak ki, megnövelve a sejten belüli reaktív oxigénformák (ROS) és nitrogén-monoxid (NO) mennyiségét. A szalicilsav (SA) endogén jelátvivő molekula többek között a növényi kórokozók elleni védekezési mechanizmusokban, ugyanakkor fontos szerepe van az oxidatív és nitrozatív stresszel kapcsolatos folyamatokban a különböző antioxidáns enzimek aktivitásának szabályozásán keresztül is. A poliaminok (PA) kis molekulatömegü, biológiailag aktív molekulák, melyek szignálmolekulaként közvetlenül vagy a katabolizmusuk által közvetett módon kulcsfontosságú szereppel bírnak a biotikus stresszfolyamatokban. A PA-ok mennyiségét és metabolizmusát azonban nemcsak az SA, hanem a biotikus stresszfolyamatokban ugyancsak fontos szerepet játszó, gáz halmazállapotú hormon, az etilén (ET) is nagymértékben befolyásolja. A PA-ok és az ET között ugyanis kompetitív kapcsolat áll fenn, mivel mindkét molekula bioszintézisének közös prekurzora az S-adenozil-L-metionin (SAM). Emellett azonban a növények védekezési reakciója a patogénekkel szemben nagyban függ a környezeti faktoroktól is, mint például a fénytől. A fénynek ugyanis fontos szerepe van a növényi immunválasz kiváltásában.

Munkánk egyik felében célul tüztük ki, hogy megvizsgáljuk, milyen különbségek figyelhetők meg az idő függvényében az akklimatizációt segítő szubletális SA koncentrációval történő kezelés, valamint a magasabb koncentrációjú, programozott sejthalált (PCD) indukáló SA hatásai között, normál fotoperióduson és sötétben. Mivel a PA-ok metabolizmusa és az ET közötti kapcsolat az irodalom alapján ellentmondásos, ezért munkánk második felében megvizsgáltuk, hogyan változnak exogén SA kezelés hatására ezen fontos molekulák mennyiségei, valamint a PA-ok bioszintézisében és lebontásában szereplő különböző enzimek expressziója és/vagy aktivitása. Vizsgáltuk a ROS generálásában és kioltásában szereplő legfontosabb enzimeket egy ET receptor mutáns, Never-ripe paradicsom leveleiben, 24 óráig tartó szubletális és letális SA koncentrációval történő kezelés hatására, valamint azt, hogy ezeket a változásokat milyen mértékben befolyásolja a fény jelenléte vagy annak hiánya. 


\section{Irodalmi áttekintés}

\subsection{A biotikus stresszben szerepet játszó jelátviteli molekulák és enzimek}

\subsubsection{A szalicilsav élettani hatása, bioszintézise és konjugációja}

A növényeket érintő stressztényezők közül az egyik legfontosabb a biotikus stressz, amelyet különböző élőlények úgy, mint baktériumok, gombák és fertőző ágensek (vírusok) válthatnak ki, ebben játszik szerepet az SA, mely egy másodlagos anyagcseretermék, a növényi fenolvegyületek csoportjába tartozó hormonszerü benzoesav származék.

Az SA élettani hatásai nagymértékben függnek a növényi fajtól, az adott szervtől és növény fejlődési állapotától, az alkalmazott exogén kezelés koncentrációjától, módjától és időtartamától (Horváth és mtsai., 2015). Megállapítható, hogy az SA magas koncentrációban történő alkalmazása gátolja a csírázást, a növekedést és a fotoszintetikus aktivitást, aminek egyik oka, hogy az SA szabályozza a növények vízháztartását csökkentve a vízpotenciált és a sztómakonduktanciát, míg alacsony koncentrációban serkenti azokat. Továbbá indukálja a szeneszcenciát, valamint a sejtek redox állapotát az antioxidáns enzimek aktivitásának szabályozásán keresztül (Poór és mtsai., 2011; Janda és mtsai., 2012; Sahu 2013). Ugyanakkor az SA élettani hatásai az irodalom alapján sok esetben ellentmondásosnak, ismereteink pedig még hiányosnak mondhatóak. Ennek egyik oka lehet, hogy kontroll körülmények között az SA endogén mennyisége növényfajonként is jelentős eltérést mutat. A dohány (Nicotiana tabacum) levelében alacsony, $[<100 \mathrm{ng} / \mathrm{g}$ friss tömeg (FT)] SA koncentrációk figyelhetők meg, a burgonya (Solanum tuberosum) $10 \mu \mathrm{g} / \mathrm{g}$ FT, míg a rizs (Oriza sativa) akár $40 \mu \mathrm{g} / \mathrm{g}$ FT SA-at is tartalmazhat (Takatsuji 2014). Ezzel szemben a modellnövénynek számító lúdfüben (Arabidopsis thaliana) átlagosan 0,25-1 $\mu \mathrm{g} / \mathrm{g}$ FT SA fordul elö, míg az árpában (Hordeum vulgare), szójában (Glycine max) az SA szint körülbelül $1 \mu \mathrm{g} / \mathrm{g}$ FT (Hayat és mtsai., 2010). Legnagyobb mennyiségben hőtermelő növények virágzásakor, illetve patogénfertőzés után mutatható ki a növényekben (Raskin 1992).

Mivel a növényeknek az állatokkal szemben nincsenek speciális immunsejtjeik (pl. makrofágok), amelyek megtámadnák, legyengítenék és elpusztítanák a különböző patogéneket, ezért általános szöveti válasz, úgynevezett hiperszenzitív reakció (HR) alakul ki avirulens, biotróf kórokozók hatására, amiben az SA-nak fontos szerepe van. Ezáltal az ellenálló növények a fertőzés helye körül a sejtek „elhalásával” nekrotikus léziókat alakítanak ki úgy, hogy ezekben az elhalt foltokban és annak környékén jelentősen megnő az endogén SA, ROS- és nitrogénformák szintje. A membránlipidek peroxidációját, a proteinek oxidációját, különböző 
enzimgátlást, valamint a DNS és az RNS károsodását okozó, a kioltó mechanizmusokat túllépő oxidatív stressz végül PCD-hez vezethet (De Pinto és mtsai., 2012). Kontroll paradicsom (Solanum lycopersicum) növények gyökerében $0,2 \mu \mathrm{g} / \mathrm{g}$ FT az endogén SA mennyisége, ami gombás (Fusarium oxysporum f. sp. lycopersici) fertőzést követően tízszeresére emelkedett (Mandal és mtsai., 2009). Enyedi és mtsai. (1992) kimutatták, hogy dohány mozaik vírus (Tobacco Mosaic Virus, TMV) hatására akár ötvenszeresére is emelkedhet az endogén SA szintje dohányban.

Az SA bioszintézise során a fenilalanin elöször transz-fahéjsavvá alakul a fenilalaninammónia-liáz (PAL) enzim katalizálta reakcióval. Ezután az SA kétféleképpen keletkezhet a transz-fahéjsav aromás gyürüjének hidroxilációs és az oldallánc oxidációs reakciójának sorrendje során (1. ábra). Az első útvonalon a fahéjsav orto-hidroxi-fahéjsavvá (o-HCA, okumársav) alakul egy hidroxilációs lépés során, majd az $o$-HCA az oldalláncon tovább oxidálódik SA-vá. A másik lehetőség során az oldallánc oxidációja következtében benzoesav (BA), majd ezután az aromás gyürü hidroxilációja során SA keletkezik, mely reakciót a benzoesav-2-hidroxiláz (BA2H) enzim katalizálja (Dempsey és Klessig 2017).

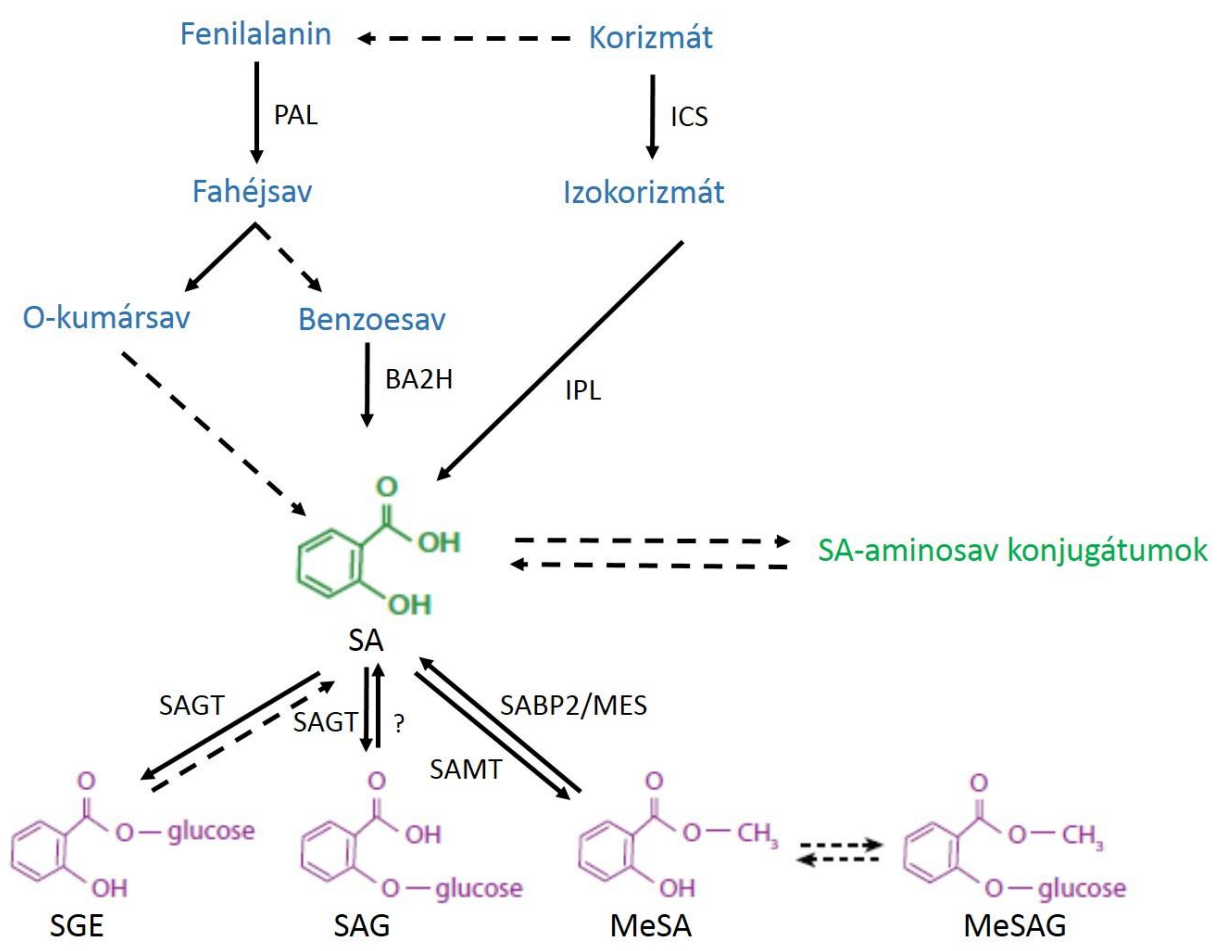

1. ábra: Az SA bioszintézisének és metabolizmusának egyszerüsített, sematikus ábrázolása [Garcion és Métraux (2006) alapján módosítva].

BA2H: Benzoesav-2-hidroxiláz; ICS: Izokorizmát-szintáz; IPL: Izokorizmát-piruvát-liáz; PAL: Fenilalaninammónia-liáz; SA: Szalicilsav; SABP2: SA-kötő fehérje; SAG: SA 2-O- $\beta$-D-glükozid; SAGT: SA-glükoziltranszferáz; SAMT: SA-karboxil-metiltranszferáz; SGE: SA-glükozil-észter; MES: metil-transzferáz; MeSA: metil-szalicilsav; MeSAG: MeSA 2-O- $\beta$-D-glükozid 
Izotópos vizsgálatok kimutatták, hogy dohányban, rizsben, burgonyában, uborkában (Cucumis sativus), napraforgóban (Helianthus anuus) és borsóban (Pisum sativum) az SA bioszintézise főleg a BA útvonalon keresztül történik, míg más növényekre inkább az $o$-kumársavból történő útvonal a jellemzőbb (Chen és mtsai., 2009). Azonban szártalan kankalinban (Primula acaulis) és kúszó fajdbogyóban (Gaultheria procumbens) mindkét útvonal jelentősége kimutatható. Paradicsom növényekben az SA legtöbbször a BA útvonalon keresztül szintetizálódik, azonban Agrobacterium tumefaciens fertőzést követően a transz-fehéjsav o-kumársavvá történö hidroxilációja a jellemzőbb (Chen és mtsai., 2009). Egy harmadik SA bioszintézis útvonal a korizmát izokorizmát átalakulása lehet, melyet elöszőr baktériumokban, később pedig lúdfü kloroplasztiszaiban is kimutattak, ahol az SA szintéziséért az izokorizmát-szintáz (ICS) enzim a felelős (1. ábra).

Az SA a citoplazmában csak kis mennyiségben található szabad formában, nagyobb része glikozilált, metilált, glükóz-észter vagy aminosav konjugátum formájában fordulhat elö (Lee és mtsai., 1995) (1. ábra). Ha a glükóz az SA hidroxil csoportjához kapcsolódik, akkor SA glükozidok (SAG, SA 2-O- $\beta$-D-glükozid), ha viszont a karboxil csoportjához, akkor SAglükozil-észterek (SGE) keletkeznek. Mindkét reakciót a citoszolikus SA-glükozil-transzferáz (SAGT) enzim katalizálja, amely indukciót mutat exogén SA kezelés, valamint patogén fertőzés során is (Song 2006). Szója és dohány sejtekben a SAG a citoszolból a vakuólumba transzportálódik, ahol inaktívan raktározódik és egy könnyen mobilizálható SA raktárat képez (Dean és mtsai., 2005). Az SA ezen felül metil-szalicicilsavvá (MeSA) is alakulhat, ami transzlokálódhat és átalakulhat aktív SA-vá. Egyes szövetek hömérséklete a környezet hőmérsékleténél akár $10-15^{\circ} \mathrm{C}$-kal is magasabbra emelkedhet, amely során a MeSA légnemüvé is válhat (volatilizáció), amely fontos szerepet játszik a hosszú távú szignáltranszdukcióban, ezáltal pedig a fertőzéstől távolabbi szervekben a szisztemikus szerzett rezisztencia (SAR) kialakításában (Vlot és mtsai., 2008). Irodalmi adatokból tudjuk, hogy az SA a kromatin átrendeződésével, valamint hiszton módosításokkal alakítja ki a SAR-t, továbbá a HR és a SAR alapja, hogy a fertőzés hatására úgynevezett patogenezissel kapcsolatos $(P R)$ gének expressziója induljon meg (Jaskiewicz és mtsai., 2011). Az SA átalakulását MeSA-vá az SA karboxil-metiltranszferáz (SAMT) enzim végzi, míg az SA-kötő fehérje 2 észteráz aktivitása révén képes a MeSA-ból SA-at felszabadítani (Park és mtsai., 2007). A MeSA a hidroxil csoportján keresztuil képes tovább glikozilálódni, miközben MeSA 2-O- $\beta$-D-glükozid (MeSAG) keletkezik, mely a SAG-al ellentétben nem tárolódik a vakuólumban. Az SA aminosavakhoz történő konjugációja befolyásolja az SA hatását is, valamint az ellenállóságot a betegségekkel szemben, ugyanis képes növelni egy acil-adenilát/tioésztert-képző enzim 
(GH3.5) expresszióját, amely az SA aminosavakhoz történő konjugációjában játszik szerepet (Zhang és mtsai., 2007). Továbbá a GH3.5 túlexpresszáltatása növeli az SA felhalmozódását is (Park és mtsai., 2007).

\subsubsection{Az SA által indukált jelátvitel}

Az SA válasz kialakításában kulcsfontosságú szereppel bírnak a másodlagos jelátvivő molekulák, úgymint a ROS, azon belül is a hidrogén-peroxid $\left(\mathrm{H}_{2} \mathrm{O}_{2}\right)$, valamint az $\mathrm{NO}$ (Gémes és mtsai., 2011; Li és mtsai., 2015a). Az SA alacsony koncentrációban kismértékủ oxidatív stresszt generál, amely hozzájárulhat a növények stresszrezisztenciájának fokozásához az antioxidáns enzimek aktivitásának szabalyozásán keresztül, míg magas koncentrációban az erőteljes oxidatív stresszt indukaló hatása miatt PCD-t indukálhat (Németh és mtsai., 2002; Szepesi és mtsai., 2009).

Az SA-indukált jelátvitel kezdeti szakaszán egy oxidatív fázist figyelhetünk meg, amelyet a ROS szintek átmeneti növekedése, valamint a glutation redukált arányának csökkenése jellemez. Az oxidatív fázis során az SA-függő primer válaszgének, így a különböző antioxidáns enzimek expressziója figyelhető meg (Han és mtsai., 2012). Az oxidatív szakaszt egy későbbi, reduktív szakasz követ, amely redox szabályozás alatt áll (Herrera-Vásquez és mtsai., 2015). Az SA-indukálta védelmi gének aktiválásában az egyik legjelentősebb szabályzó fehérje a citoplazmában található non-expressor of pathogenesis-related 1 (NPR1), amit diszulfid hidak stabilizálnak. Az SA hatására a sejt redox állapota megváltozik, az NPR1 molekulák közötti diszulfid hidak redukálódnak, majd a keletkező aktív monomerek a sejtmagba transzlokálódva aktiválják a TGA1 és TGA4 transzkripciós faktorokat, aminek hatására $P R$ gének íródnak át (Mou és mtsai., 2003; Fobert és Despres 2005). A $P R$ gének peroxidázokat, kitinázokat, defenzineket, proteáz inhibitorokat és számos antifungális hatású proteint kódolnak, amelyek meghatározzák a növények védekezését (van Loon és van Strien 1999). Lu és mtsai. (2013) kimutattak, hogy a $P R-1$ (PR-1-1 és $P R-1-5)$ gének humán kaszpázszerü doménnal rendelkeznek és így szabályozhatják a PCD folyamatát a növényekben is.

Az SA szinteket koncentrációtól függően a kis affinitású, nagy SA koncentrációkra érzékeny NPR3, valamint a nagy affinitású, kis SA koncentrációnál szerepet játszó NPR4 receptor érzekeli (Gust és Nürnberger 2012). Az NPR3 az SA kötődése után az NPR1-et az E3 ubiquitin ligázhoz kapcsolja, amely ubiquitinálódás után lebomlik, majd PCD indukálodik. Ezzel szemben az NPR4 megakadályozza az NPR1 lebomlását, ezáltal fokozva a SAR kialakulását. Azonban az SA az NPR1 521/529-es ciszteinen található $\mathrm{Cu}^{2+}$ ionon keresztül 
képes kötődni és konformáció változást indukálni, bizonyítva, hogy maga az NPR1 fehérje is SA receptor (Wu és mtsai., 2012).

Az NPR1-függő útvonal mellett ismert az SA mitogén-aktivált protein kináz (MAPK) kaszkádon keresztüli jelátvitele is (Miura és Tada 2014). Lúdfüben az SA-indukálta védelmi válaszok, valamint a $P R$ gének expressziójának pozitív szabályozói a MAPK kaszkád részét kepző AtMPK3/AtMPK6, míg az AtMPK4 jelátvitel gátolja azokat. Emellett a MAP kináz foszfát 1 (AtMKP1) egyrészt gátolja az SA bioszintézist, másrészt pedig az AtMPK3/AtMPK6 kaszkád represszora is (Bartels és mtsai., 2009).

\subsection{Reaktív oxigénformák}

A növényi sejteken belüli ROS-kat három különálló csoportra oszthatjuk, melyek kémiai tulajdonságai nagyban eltérnek egymástól (Foyer és Noctor 2009). Az első csoportba tartoznak a párosítatlan elektronnal rendelkező oxigén szabadgyökök, úgy mint a szuperoxid gyökanion $\left(\cdot \mathrm{O}_{2}{ }^{-}\right)$, hidroperoxil gyök $\left(\mathrm{OH}_{2}{ }^{-}\right)$, valamint a hidroxil gyök $(\mathrm{OH})$. A második csoportba tartozik a további szabadgyök képzésre képes $\mathrm{H}_{2} \mathrm{O}_{2}$, míg a harmadik csoportba a rendkívül reakcióképes szinglet oxigén $\left({ }^{1} \mathrm{O}_{2}\right)$ tartozik, amely további szabadgyököket nem képez (Das és Roychoudhury 2014).

Egy elektron felvételével a molekuláris oxigenből $\left(\mathrm{O}_{2}\right) \cdot \mathrm{O}_{2}^{-}$keletkezik, amely rövid életidejü (féléletideje 2-4 $\mu$ s), mérsékelten reakcióképes oxigénforma és csak korlátozottan képes a membránokon keresztüli diffúzióra. Csaknem minden sejtkompartmentumban, így a mitokondriumban, kloroplasztiszban, az endoplazmatikus retikulumban (ER), a glioxiszómákban, a peroxiszómákban, az apoplasztban és a citoszolban is keletkezhet. $\mathrm{A} \mathrm{OH}_{2}{ }^{-}$a $\cdot \mathrm{O}_{2}{ }^{-}$protonált formája, amely ezáltal lipidoldékonyabb. $\mathrm{A} \cdot \mathrm{O}_{2}{ }^{-}$további elektronfelvétellel a Haber-Weiss ciklus során $\mathrm{H}_{2} \mathrm{O}_{2}$-vé alakulhat, amelyből a Fenton-reakciót képző fém katalizátorok jelenléte mellett egy újabb elektron felvételével $\mathrm{OH}$ keletkezik. $\mathrm{A} \mathrm{OH}$ féléletideje 1 ns, a legreaktívabb oxigénforma, így a sejten belüli makromolekulákat és sejtorganellumokat irreverzibilis módon károsíthatja, túlzott termelődése pedig végső soron sejthalálhoz vezethet (Vranová és mtsai., 2002; Foyer és Noctor 2009) (2. ábra). 


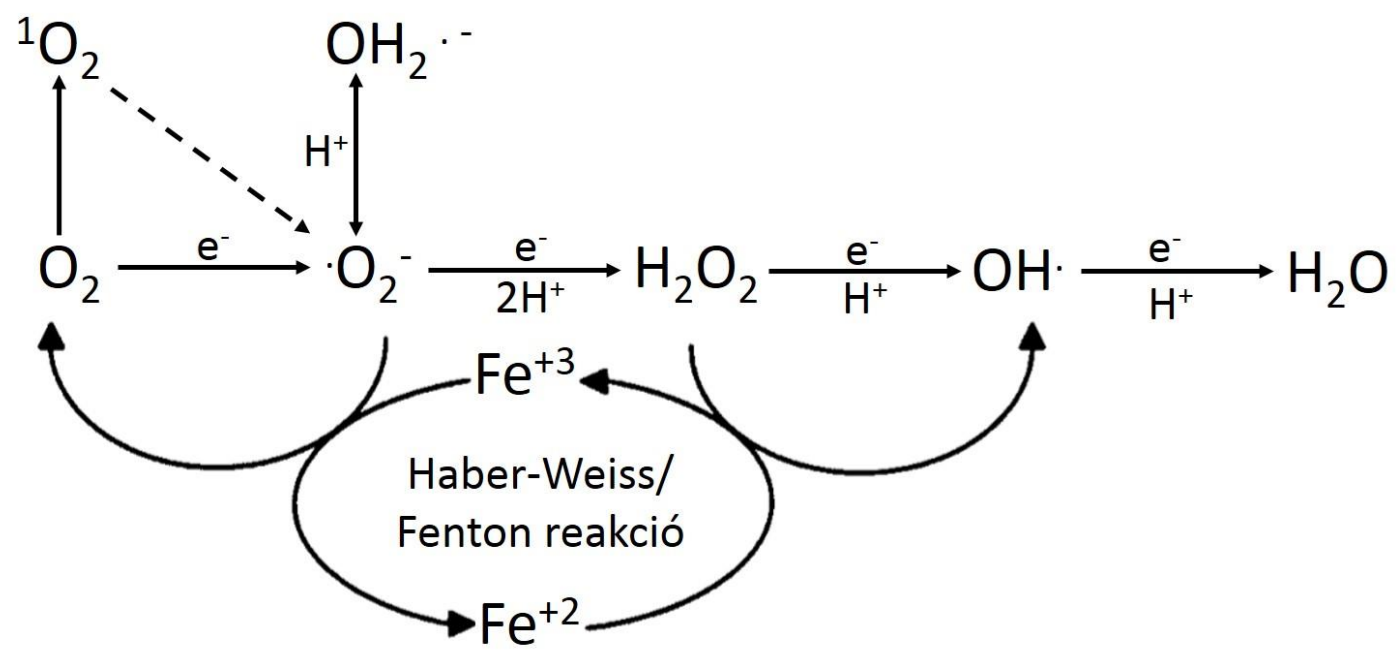

2. ábra: A molekuláris oxigén sorozatos redukciójának egyszerüsített, sematikus ábrázolása [Vranová és mtsai., (2002) alapján módosítva].

A molekuláris oxigén $\left(\mathbf{O}_{2}\right)$ aktivációja történhet ellentétes spinű szinglet állapotra gerjesztődéssel vagy az $\mathrm{O}_{2}$ négy elektronos redukciójával. A szuperoxid gyökanion $\left(\mathbf{O}^{-} \mathbf{2}^{-}\right)$egy proton felvételével hidroperoxil gyökké $\left(\mathbf{O H}^{\cdot-)}\right.$ alakulhat spontán módon. A $\mathrm{O}_{2}^{-}$és a $\mathrm{OH}_{2}{ }^{-}$vizes közegben hidrogén-peroxiddá $\left(\mathbf{H}_{2} \mathbf{O}_{2}\right)$ alakulhat. $\mathrm{A} \mathrm{H}_{2} \mathrm{O}_{2}$ átalakulhat hidroxil gyökké (OH·) a $\mathrm{O}_{2}^{-}$katalizálta Haber-Weiss reakció, valamint a fém-katalizált Fenton-reakció során, ahol a $\mathrm{O}_{2}{ }^{-}$segíti az oxidált fémionok visszaredukálását $\left(\mathbf{F e}^{3+}\right.$ redukálódik $\left.\mathbf{F e}^{2+}\right)$.

A ROS-ok közül az egyik legjobban tanulmányozott a közepes reakcióképességü $\mathrm{H}_{2} \mathrm{O}_{2}$, amely a legstabilabb ROS (féléletideje $1 \mathrm{~ms}$ ), és a membránokon és az akvaporinokon keresztül is képes átdiffundálni (Moller és Sweetlove 2010). Ezáltal másodlagos jelátviteli molekulaként elösegítheti az antioxidáns védekezési válaszok aktivációját, ily módon szabályozva a stresszadaptációt, az egyedfejlődés egyes lépéseit és a sejthalált is (van Aken és van Breusegem 2015). Alacsony koncentrációban védelmi szignálmolekulaként, magas koncentrációban pedig citotoxikus prooxidánsként viselkedik. $\mathrm{A}_{2} \mathrm{O}_{2}$ változásokat idézhet elő a redox jelátvitelben, melynek következtében a sejt vagy osztódik vagy elpusztul (De Pinto és mtsai., 2012). Továbbá a ${ }^{\circ} \mathrm{O}_{2}{ }^{-}$és a $\mathrm{H}_{2} \mathrm{O}_{2}$ sejten belüli aránya döntő fontosságú a transzkripcionális szabályozásban is (Andronis és mtsai., 2014).

A különböző ROS-ok számos módon keletkezhetnek, többek között a fotoszintetikus és mitokondriális elektrontranszportlánc túlterheltsége során bekövetkező elektron kiáramlás következtében. A különböző oxidázok és peroxidázok például a plazmamembránhoz (PM) kötött NADPH-oxidáz (NOX, Rboh) és a sejtfalhoz vagy a peroxiszómákhoz kötött peroxidázok, amin-oxidázok [főleg a diamin-oxidáz (DAO), poliamin-oxidáz (PAO)] és a sejtfali oxalát-oxidázok reakciótermékeként is képződhet $\mathrm{H}_{2} \mathrm{O}_{2}$ (Mittler és mtsai., 2011; Sierla és mtsai., 2013). 
A mitokondriális elektrontranszportlánc müködése során az I-es és III-as komplex, valamint az alternatív oxidáz katalizálja a molekuláris oxigénre történő elektronáramlást, mely során $\cdot \mathrm{O}_{2}^{-}$keletkezhet. Ez tovább dizmutálódhat $\mathrm{H}_{2} \mathrm{O}_{2}$-vé (Noctor és mtsai., 2007), amely hatással lehet az apoplasztikus ROS metabolizmusára is (Podgórska és mtsai., 2015).

A kloroplasztiszokban a fotoszintetikus elektrontranszportlánc II-es fotokémiai rendszerének (PSII) müködése közben ${ }^{1} \mathrm{O}_{2}$, míg az I-es fotokémiai rendszer (PSI) működése során $\cdot \mathrm{O}_{2}^{-}$keletkezhet, mely gyorsan $\mathrm{H}_{2} \mathrm{O}_{2}$-vé alakulhat (Sierla és mtsai., 2013). A C3-as növényekben a fotoszintetikus eletrontranszportlánc végső elektron akceptorának, a NADPH pool túlredukáltságának elkerülése érdekében kialakulhat a fotorespiráció jelensége, amely során a peroxiszómákban is keletkezhet $\mathrm{H}_{2} \mathrm{O}_{2}$ (Del Río és mtsai., 2006).

A PM lokalizált NOX, amelyre az SA serkentő hatással bír, szintén jelentős az oxidatív stressz kialakításában, ugyanis müködése közben $\mathrm{O}_{2}{ }^{-}$-ot generál az apoplaszt felé, amely tovább alakulhat $\mathrm{H}_{2} \mathrm{O}_{2}$-vé (Podgórska és mtsai., 2017). Ezzel a NOX döntő szerepet játszik a sejtről sejtre történő ROS hullám kialakításában is (Mittler és mtsai., 2011), melynek sebessége körülbelül $8 \mathrm{~cm} \cdot \min ^{-1}$ (Miller és mtsai., 2009). A sejtfal-kötött peroxidázok, valamint az apoplasztikus lokalizáltságú oxalát oxidázok és amin oxidázok (DAO és PAO) a $\mathrm{H}_{2} \mathrm{O}_{2}$ termelődésének növelésével ugyancsak hozzájárulnak a HR kialakításához (Kärkönen és Kuchitsu 2015).

A biotróf kórokozók elleni védekezésben az SA-nak, míg a jázmonsavnak (JA) és az ET a nekrotróf patogénekkel szembeni védekezésben van meghatározó szerepük (Glazebrook 2005). Biotróf patogén fertőzés következtében bekövetkező gyors sejthalál során egy korai oxidatív robbanás figyelhető meg az apoplasztban, amely a $\mathrm{O}_{2}{ }^{-}$és a $\mathrm{H}_{2} \mathrm{O}_{2}$ gyors, náhány perc alatti emelkedésével jár (De Pinto és mtsai., 2012). Néhány órával később egy második, hosszabb ideig tartó ROS maximum figyelhető meg. A megemelkedett ROS azon belül is a $\mathrm{H}_{2} \mathrm{O}_{2} \mathrm{HR}$ független módon, a sejtfal megerösítésével, citoplazmatikus $\mathrm{Ca}^{2+}$ koncentrációjának megemelésével, MAPK kaszkád aktivációjával és génexpressziós változtatással is képes PCD-t indukálni és növelni a patogénekkel szembeni ellenállóságot (Nanda és mtsai., 2010). Érdekesség, hogy egy öngerjesztő SA- $\mathrm{H}_{2} \mathrm{O}_{2}$ ciklus során nemcsak az SA hatására nőhet meg a ROS mennyisége, hanem maga a ROS is fokozhatja az SA felhalmozódását a növényi sejtekben (Wi és mtsai., 2010).

\subsection{Reaktív nitrogénformák}

A ROS mellett egy másik jelentős szignálmolekula, a színtelen, gáz halmazállapotú, erőteljesen reaktív NO, amely a biológiai rendszerekben egy $\mathrm{e}^{-}$felvételével vagy leadásával három 
formában létezik: nitrogén-monoxid gyökként (NO), nitrozónium kationként $\left(\mathrm{NO}^{+}\right)$és nitroxil anionként $\left(\mathrm{NO}^{-}\right)$. Könnyen képes reakcióba lépni $\mathrm{O}_{2}$-el, ezáltal nitrogén-dioxid $\left(\mathrm{NO}_{2}\right)$ keletkezik, amely vízfelvétellel tovább alakulhat nitráttá $\left(\mathrm{NO}_{3}{ }^{-}\right)$vagy nitritté $\left(\mathrm{NO}_{2}^{-}\right) . \mathrm{Az} \mathrm{NO}$ bioszintézisében a növényekben elsősorban a citoplazmatikus- és PM-kötött nitrát-reduktáz (cNR, PM-NR), valamint a nitrit:NO reduktáz (NI-NOR) enzim játszik fontos szerepet (Cohen és mtsai., 2014). Az állatihoz hasonló NO-szintáz (NOS, EC 1.14.14.39) enzim növényekben való létezése egészen 2016-ig kérdéses volt. Ekkor több mint 1000 különbözö növényfaj transzkriptum elemzése során az emberi neuronális NOS-al (nNOS) homológiát mutató gént is azonosítottak, azonban a szerzők csak csekély esélyét látják annak, hogy a növényekben az NO szintézis jelentős részét NOS-szerü enzimek végeznék (Jeandroz és mtsai., 2016). $\mathrm{Az} \mathrm{NO}_{2}{ }^{-}$ tovább redukálódhat NO-á a mitokondriális elektrontranszportláncon keresztül is (Gupta és Igamberdiev 2016). Az NO aerob körülmények között ${ }^{\circ} \mathrm{O}_{2}{ }^{-}$-al vagy $\mathrm{H}_{2} \mathrm{O}_{2}$-vel is képes reakcióba lépni, mely során peroxinitrit $\left(\mathrm{ONOO}^{-}\right)$keletkezhet (Podgórska és mtsai., 2017), amely károsíthatja a DNS-t, RNS-t, fehérjéket és lipideket, ezzel PCD-t indukálva (Astier és Lindermayr 2012). Az NO-nak a ROS-hoz képest hosszú, perces féléletideje is lehet, továbbá hidrofóbb tulajdonsága révén képes a biologiai membránokon átdiffundálni, ezáltal hosszabb távolságokra is eljutni (Arasimowicz-Jelonek és mtsai., 2014). Kulcsszerepet játszik a biotikus stresszválaszokban (Bellin és mtsai., 2013), valamint az adaptív válaszgének, úgymint az ET bioszintézisében és jelátvitelében szerepet játszó enzimek és fehérjék, valamint antioxidáns enzimeket kódoló génjeik bekapcsolásában is (Mur és mtsai., 2013). Az NO kulcsfontosságú intermedier molekula az SA, ET és a PA-ok szignalizációjában (Freschi 2013) és bioszintézisében is (Montilla-Bascón és mtsai., 2017). Közremüködik a szeneszcencia és a PCD folyamatában (Wojciechowska és mtsai., 2017) ugyanis koncentrációtól függő módon lehet védelmi szignálmolekula vagy citotoxikus hatású is (Locato és mtsai., 2016). Az NO magas szintje azonban önmagában ROS nélkül nem okoz HR-t (Scheler és mtsai., 2013). Exogén $\mathrm{H}_{2} \mathrm{O}_{2}$ kezelés során gyors NO szintézis volt megfigyelhető lúdfü növények zárósejtjeiben, ami sztómazáródást indukált (Bright és mtsai., 2006). Patogéntámadást követő HR során a sejtekben az egyidejü $\mathrm{H}_{2} \mathrm{O}_{2}$ és $\mathrm{NO}$ termelődése, valamint az $\mathrm{NO}: \mathrm{O}_{2}{ }^{-}$aránya nagymértékben meghatározza a PCD mértékét (Locato és mtsai., 2016). A peroxiszomákból származó ROS és NO együttesen vesz részt borsó levelek szeneszcenciájának indukciójaban is (Corpas és mtsai., 2004). Biotikus stressz során az NO és az SA között pozitív kapcsolat figyelhető meg ugyanis az NO, valamint az NO donorok, úgymint a nátrium-nitroprusszid (SNP) és S-nitrozo-N-acetil-DL-penicillamin (SNAP) indukálják az SA felhalmozódását. Az SA jelenléte is szükséges az NO indukálta védelmi folyamatokhoz, mint például a $P R$ és az oxidatív stresszel kapcsolatos gének aktivációjához (Grün és mtsai., 2006). Az SA koncentrációtól függő módon képes az NO 
indukciójára lúdfü csíranövényekben, amely szintén hozzájárulhat a PCD kialakulásához (Zottini és mtsai., 2007). Ugyanakkor az SA felhalmozódására képtelen transzgénikus dohány növények, melyek a bakteriális eredetü (Pseudomonas putida) szalicilát-hidroxiláz enzim génjét (nahG) hordozzák, képtelenek a SAR kialakítására (Gaffney és mtsai., 1993). A nahG expressziója gátolta az NO által indukálható helyi és szisztemikus rezisztenciát TMV fertőzött dohányban, míg az SA indukálta SAR kialakulása nem történt meg az NO bioszintézisét gátló $\mathrm{N}^{\mathrm{G}}$-monometil-L-arginin (L-NMMA) vagy az NO-t közvetlenül kioltó 2-(4-karboxifenil)4,4,5,5-tetrametilimidazolin-1-oxil-3-oxid kálium só (cPTIO) használata után (Song és mtsai., 2001).

Az NO jelátvitelben betöltött szerepe a fehérjék tirozin nitrációján vagy S-nitrolizációján keresztuil valósulhat meg. A tirozin nitráció során a fehérjék specifikus pozícióban lévő tirozin aminosavának orto helyzetű szénatomjára egy nitrocsoport $\left(-\mathrm{NO}_{2}\right)$ kapcsolódik, mely során a fehérje szerkezete megváltozik, ezáltal aktivitása a legtöbb esetben gátlódik, azonban elöfordulhat, hogy aktivitása fokozódik vagy a protein müködése nem változik (Corpas és mtsai., 2013).

Az S-nitroziláció során az NO reverzibilis módon kölcsönhatásba lép a célfehérjék cisztein aminosavának tiol (SH) csoportjaival és S-nitrozotiollá (RSNO) alakítja azokat (Astier és mtsa, 2012). Nem az összes cisztein nitrozilálódik egy fehérjén belül, mivel az, hogy mely fehérje szenved S-nitrozilációt függ az adott fehérje sejten belüli lokalizációjától és az NO koncentrációjától is (Lamotte és mtsai., 2015). Ezidáig több mint 100 S-nitrozilációra hajlamos fehérjét azonosítottak (Astier és mtsai., 2012). Az S-nitroziláció többek között képes például a NOX aktivitását gátolni a fehérje 890-es ciszteinjének (Yun és mtsai., 2011), valamint az NPR1 fehérje oligomerizációját fenntartani a 156-os ciszteinjének S-nitrozilációján keresztül (Tada és mtsai., 2008; Lindermayr és mtsai., 2010). Emellett képes számos egyéb fehérjét, úgymint a redox folyamatban résztvevő kataláz (KAT), szuperoxid-dizmutáz (SOD) és aszkorbátperoxidáz (APX) enzimeket S-nitrozilálni és azok funkcióját poszt-transzlációs módon megváltoztatni (Lindermayr és mtsai., 2005; Kato és mtsai., 2012; Begara-Morales és mtsai., 2014). Nemcsak fehérjékkel, hanem alacsony molekulasúlyú tiolokkal, például a glutationnal is képes reakcióba lépni létrehozva az S-nitrozoglutationt (GSNO), amely fontos szerepet játszik az NO transzportjában és raktározásában (Yun és mtsai., 2016). A GSNO szerepet játszik az NPR1 sejtmagi transzlokációjának aktiválásában is (Lindermayer és mtsai., 2010). A GSNO-t a GSNO reduktáz (GSNOR) aktivitással rendelkező enzimek, mint például a lúdfüben megtalálható alkohol-dehidrogenáz-3 (AtGSNOR1) oxidált glutationná és ammóniává alakítja, ezáltal csökkentve az endogén NO szintjét (Wilson és mtsai., 2008). 


\subsection{Antioxidáns enzimek}

Az oxidatív stressz mértéke nagyban függ a sejt típusától, a stressz mértékétől és az adott sejt védelmi mechanizmusaitól, többek között a különböző antioxidáns enzimek és a FoyerHalliwell-Asada ciklusban részt vevő enzimek aktivitásától (Foyer és Noctor 2009; Kocsy és mtsai., 2013).

A ROS elleni védelemben három kulcsfontosságú enzim játszik szerepet. Az enzimatikus inaktiváló mechanizmusok első védelmi vonalaként emlegetett SOD (EC 1.15.1.1.) enzim a $\cdot \mathrm{O}_{2}{ }^{-}$-t protonfelvétellel $\mathrm{H}_{2} \mathrm{O}_{2}$-vé és molekuláris oxigénné alakítja (Podgórska és mtsai., 2017). A SOD izoformái csaknem minden sejtkompartmentumban megtalálhatóak, ugyanakkor a növényvilágban három fö izoformáját különíthetjük el annak megfelelően milyen fém iont tartalmaz. Megkülönböztetünk mitokondriális és peroxiszómális lokalizáltságot mutató mangánSOD-ot (MnSOD), kloroplasztikus lokalizáltságú vas-SOD-ot (FeSOD), valamint kloroplasztikus, citoszólikus és apoplasztikus lokalizáltságú réz/cink SOD-ot (Cu/ZnSOD) (Alscher és mtsai., 2002). A paradicsom legalább nyolc SOD gént tartalmaz, négy $C u / Z n S O D-$

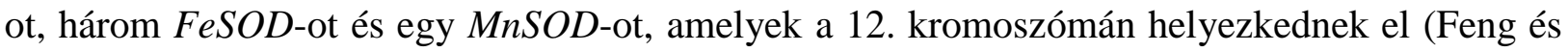
mtsai. 2016). A mangán iont tartalmazó MnSOD alegységekből épül fel és minden alegységet két domén képez, mely a fémet megkötő helyet alakítja ki, így homodimer vagy homotetramer formában fordul elö. A MnSOD aktivitása sem kálium-cianiddal $(\mathrm{KCN})$, sem pedig $\mathrm{H}_{2} \mathrm{O}_{2}$ nem gátolható (Kuo és mtsai., 2013). Az FeSOD izoenzimek a MnSOD-hoz hasonlóan dimer és tetramer szerkezetben is előfordulnak. A dimer FeSOD monomer egységei $20 \mathrm{kDa}$ molekulatömegüek. A monomer részeket két domén alkotja, mely az aktív centrumot és a fémiont tartalmazza. $\mathrm{A}_{2} \mathrm{O}_{2}$ gátolja, míg a $\mathrm{KCN}$ nincs hatással az aktivitására (Kuo és mtsai., 2013). A Cu/ZnSOD izoenzimek hasonlóan az előző izoenzimekhez homodimer és homotetramer formában is előfordulnak. Aktív centrumuk két központi iont is tartalmaz, továbbá aktivitásuk mind $\mathrm{KCN}$-dal, mind pedig $\mathrm{H}_{2} \mathrm{O}_{2}$-vel gátolható (Kuo és mtsai., 2013).

A keletkezett $\mathrm{H}_{2} \mathrm{O}_{2}$-ot vízzé és molekuláris oxigénné bontó KAT (EC 1.11.1.6.) enzim négy alegységből álló, hem prosztetikus csoportot tartalmazó, 220 kDa molekultömegü enzim, azonban előfordulhat dimer vagy nem hem prosztetikus csoportot tartalmazó KAT is (Podgórska és mtsai., 2017). Az egyik legjelentősebb $\mathrm{H}_{2} \mathrm{O}_{2}$ semlegesítő enzim, amelyet a legtöbb növényi genom három izoformában (KAT1, KAT2 es KAT3) kódol. Megtalálhatóak a peroxiszómákban, a glioxiszómákban (KAT1 es KAT2), azonban a KAT1 (Bayer és mtsai., 2006) és KAT3 (O'Brien és mtsai., 2012) sejtfal lokalizáltságot is mutat. Továbbá kukorica és spenót esetében a KAT3 mitokondriumokban is előfordulnak (Mhamdi és mtsai., 2010). A KAT enzimeket expressziójuk alapján három osztályba sorolják: az I. osztályba tartozó KAT enzimek leginkább fotoszintetikus 
szövetekben expresszálódnak, szintézisük fényfüggö, ilyen például a KAT2 lúdfüben vagy kukoricában. A II. osztályba tartozó KAT-ok leginkább a vaszkuláris szövetekben fejeződnek ki, úgy mint a KAT1 lúdfüben, KATA rizsben vagy a TOMKAT1 paradicsomban. A III. osztályba tartoznak a glioxiszómális KAT-ok, amelyek relatív transzkript szintjei a magvakban és fiatal növényekben mutatnak nagyobb mennyiséget (Racchi 2013). A lúdfü KAT1 és KAT3 gének az egyes kromoszómán, míg a KAT2 gén a négyes kromoszómán található.

A következő, $\mathrm{H}_{2} \mathrm{O}_{2}$ eliminálásában ugyancsak fontos szerepet játszó enzim a FoyerHalliwell-Asada ciklus részét képző APX (EC 1.11.1.11.), amely protohem prosztetikus csoportot tartalmaz (Caverzan és mtsai., 2012). Az enzim elektrondonorként redukált aszkorbátot (ASC) használ. Bár az APX és a KAT egyaránt képes a $\mathrm{H}_{2} \mathrm{O}_{2}$ eliminálására, funkciójuk nem teljesen azonos, mivel az APX sokkal nagyobb affinitást mutat a $\mathrm{H}_{2} \mathrm{O}_{2}$-höz ( $\mu \mathrm{M}$-os nagyságrend), míg a KAT, amely mM-os szubsztrát koncentrációnál müködik hatékonyan és inkább a stresszfolyamatokban válik jelentőssé aktivitása (Podgórska és mtsai. 2017). Lúdfüben ezidáig nyolc APX izoformát különítettek el, amelyeknek eltérő lokalizáltságuk van: három citoszólikus (APX1, APX2, APX6), kettő kloroplasztikus (sztróma: sAPX és tilakoid: tAPX), három pedig mikroszómális (APX3, APX4, APX5) lokalizáltságot mutat (Shigeoka és mtsai., 2002). Paradicsomban három citoszólikus, kettő kloroplasztikus és kettő peroxiszómális APX fehérjét kódoló gént találtak (Najami és mtsai. 2008). Az APX1 feltételezhetően képes az apoplasztba is transzportálódni (O'Brien és mtsai., 2012). A mikroszómális APX izoenzimek elsősorban a zsírsavak $\beta$ oxidációja során keletkező $\mathrm{H}_{2} \mathrm{O}_{2}$ eliminálásában játszanak szerepet. Míg a kloroplasztikus lokalizáltságú APX izoenzimek a fotoszintetikus apparátus oxidatív stressz elleni védelmében, addig a citoszolikus enzimek általános, különböző stresszekkel szembeni védelemben játszanak szerepet (Panchuk és mtsai., 2005).

A növényi peroxidázok (POD, EC, 1.11.1.7.) protohem prosztetikus csoportot tartalmazó, glükoprotein enzimek, amelyek a KAT és az APX enzimek mellett ugyancsak a $\mathrm{H}_{2} \mathrm{O}_{2}$ eliminálásában játszanak szerepet, melyhez aromás komponenseket, főleg gvajakolt vagy pirogallolt használhatnak elektron donorként (Podgórska és mtsai., 2017). Megtalálhatóak a citoszolban, vakuolumban, sejtfalban, azonban a sejtszervecskékben így például a kloroplasztiszban nem.

Irodalmi adatok alapján, külső kezelésként alkalmazva az SA 0,5 es 1 mM közötti koncentrációban fokozta az antioxidáns védekezési rendszer hatékonyságát a KAT és POD aktiválásán keresztül szója és kukorica növényekben (Knörzer és mtsai., 1999; Janda és mtsai., 1999; Mika és mtsai., 2010). Ezzel szemben hosszantartó SA kezelés serkentette a SOD és csökkentette a KAT és APX enzimek aktivitását, ezáltal megemelve a $\mathrm{H}_{2} \mathrm{O}_{2}$ koncentrációját, 
tovább fokozva a lipidperoxidáció mértékét és a fehérjék oxidatív károsodását, amely végső soron sejthalálhoz vezetett (Wang és mtsai., 2015). Choudhury és Panda (2004) is hasonló eredményt kaptak miszerint a KAT és POD enzimek aktivitásai csökkentek, mikor a rizsszemeket csírázás előtt SA tartalmú oldatban áztatták. Az SA az APX aktivitásának csökkentésén keresztül növelte a $\mathrm{H}_{2} \mathrm{O}_{2}$ mennyiségét Astragalus adsurgens Pall. kalluszkultúrákban is (Luo és mtsai., 2001). Az SA KAT és APX gátló hatása részben magyarázatul szolgál a $\mathrm{H}_{2} \mathrm{O}_{2}$ mennyiségének megemelkedésére és az oxidatív stresszt indukáló hatására, amely a biotikus stresszfolyamatokban HR-hez vezet. Ezzel ellentétben Krantev és mtsai. (2008) azt kapták, hogy az exogén SA hatására megnövekedett a SOD és az APX enzimek aktivitása, miközben a KAT aktivitása lecsökkent kukorica növényekben. Az SA alacsony koncentrációban alkalmazva a KAT enzim átmeneti aktivitáscsökkenését okozta gabonafélékben is, ezzel megemelve a $\mathrm{H}_{2} \mathrm{O}_{2}$ koncentrációját (Janda és mtsai., 2003) és ezáltal kismértékü oxidatív stresszt generálva, ami feltehetően fontos szerepet játszik a HR és SAR kialakításában is (Shapiguzov és mtsai., 2012). Az SA tehát az antioxidáns rendszerek aktiválásával vagy bizonyos stresszvédő anyagok (PA) szintézisének fokozásával (Hussain és mtsai., 2011) hozzájárulhat a növények általános stresszrezisztenciájának kialakításához (Karpiński és mtsai., 2013).

\subsection{A poliaminok}

A PA-ok kis molekulatömegü, N-tartalmú biológiailag aktív molekulák, amelyeknek szerepük van a növények biotikus- és abiotikus stresszrezisztenciájában (Pál és mtsai., 2015). A növényekben a legnagyobb mennyiségben előforduló PA-ok a diamin putreszcin (Put), amely obligát prekurzora a triamin spermidinnek (Spd) és a tetraamin sperminnek (Spm) (Alcázar és mtsai., 2010). A növényekben a három fő formán kívül egyéb PA-ok is megtalálhatóak, mint például az 1,3-diaminopropán (DAP), a kadaverin (Cad), valamint a thermospermin (ThermSpm) is (Lutts és mtsai., 2013). Előfordulnak a természetben ritka, nem szokványos PA-ok is, amelyek az Spd és Spm molekulák származékai úgy, mint a nor-Spd, nor-Spm, homo-Spd, homo-Spm, valamint hosszabb penta- és hexaaminok is (Sagor és mtsai., 2013). A PA-ok mennyisége függ a növény fajtól, fejlődési állapotától, valamint az adott növényi szervtől is. Mennyiségük a növekedő növényi szövetekben, valamint biotikus és abiotikus stressz hatásokra általában megemelkedik (Hussain és mtsai., 2011; Gupta és mtsai., 2013). A sejten belüli PA-koncentráció függ a PA-ok bioszintézisében és lebontásában szerepet játszó fehérjék génjeinek transzkripciójától és transzlációjától, a vakuoláris és extracelluláris transzportjuktól, illetve fenolos származékokkal történő konjugációjuktól is (Kusano és Suzuki 2015). 
A PA-ok fiziológiai pH-n pozitív töltéssel rendelkeznek, ami lehetővé teszi, hogy kölcsönhatásba lépjenek és védelmet biztosítsanak olyan negatív töltésű makromolekuláknak, mint a DNS, RNS, fehérjék és foszfolipidek, ily módon részt vegyenek a membránok fizikai és kémiai tulajdonságainak, a nukleinsavak szerkezetének és az enzimek aktivitásának szabályozásában (Tiburcio és mtsai., 2014). Részt vesznek a növekedés, sejtosztódás, DNS replikáció, sejtdifferenciáció, organogenezis, embriógenezis, viráginiciáció és fejlődés, levélöregedés, biotikus és abiotikus növényi stresszválaszok folyamataiban is (Wimalasekera és mtsai., 2011a). Kölcsönhatásba léphetnek antibiotikumokkal, fenolos vegyületekkel, leginkább hidroxifahéjsavval is (Martin-Tanguy 2008).

Exogén Put, Spd vagy Spm kezelések képesek növelni a növények abiotikus és biotikus stresszel szembeni rezisztenciáját (Zhang és mtsai., 2015; Harindra Champa és mtsai., 2015). Esszenciális szerepük van a sejt túlélésében, mivel a kémiailag vagy genetikailag előidézett Put- és/vagy Spd-szintek hiánya letálisnak bizonyult élesztőben, egysejtüekben és növényekben is (Urano és mtsai., 2005). Az Spm hiányos organizmusok életképesek, de különböző mértékü rendellenességeket mutatnak, mely azt jelzi, hogy habár az Spm nem esszenciális az élethez, mégis nagyon fontos szerepet játszik a fejlődésben és növekedésben (Minguet és mtsai., 2008). A PA-oknak három formáját különíthetjük el: szabad szolubilis (Put, Spd, Spm), makromolekulákhoz kötött (például hemicellulózhoz, ligninhez), illetve kis molekulatömegü fehérjékhez konjugált formákat (Li és mtsai., 2016).

\subsubsection{A poliaminok szintézise és bioszintézisük szabályozódása növényekben}

A Put mindamellett, hogy nélkülözhetetlen szubsztrát a hosszabb szénláncú PA-ok szintéziséhez, fontos szignálmolekula a különböző stresszfolyamatokban. Növényekben a Put bioszintézise L-argininből kiindulva két útvonalon keresztuil történhet (Pegg és Casero 2011). $\mathrm{Az}$ első metabolikus útvonal során az arginin-dekarboxiláz enzim (ADC, EC 4.1.1.19) az argininből agmatint (AGM) szintetizál. Az ADC enzim fotoszintetizáló sejtek kloroplasztiszában, nem fotoszintetizáló sejteknél pedig a sejtmagban található (Bortolotti és mtsai., 2004). A keletkezett AGM-t az agmatin-iminohidroláz enzim (AIH, EC 3.5.3.12) N-karbamoilputreszcinné majd az N-karbamoilputreszcin-amidohidroláz enzim (NCPAH, EC 3.5.1.53) Put-né alakítja (3. ábra). A második metabolikus útvonalnál az argininből az argináz enzim (ARG, EC 3.5.3.1) katalizálta reakció során ornitin keletkezik, melyet a citoplazmatikus lokalizáltságú ornitin-dekarboxiláz enzim (ODC, EC 4.1.1.17) alakít Put-né (Fuell és mtsai., 2010). A Put-hoz az Spd-szintáz enzim (SPDS, EC 2.5.1.16) egy aminopropil csoportot kapcsol és így létrejön a triamin Spd. A továbbiakban az Spd-hez az Spm-szintáz enzim (SPMS, EC 
2.5.1.22) újabb aminopropil csoportot kapcsolva alakítja ki a tetraamin Spm-et. Az aminopropil csoportokat a SAM dekarboxilációja (dcSAM) biztosítja. Ezt a folyamatot a SAM-dekarboxiláz enzim (SAMDC, EC 4.1.1.50) katalizálja (Moschou és mtsai., 2012) (3. ábra).

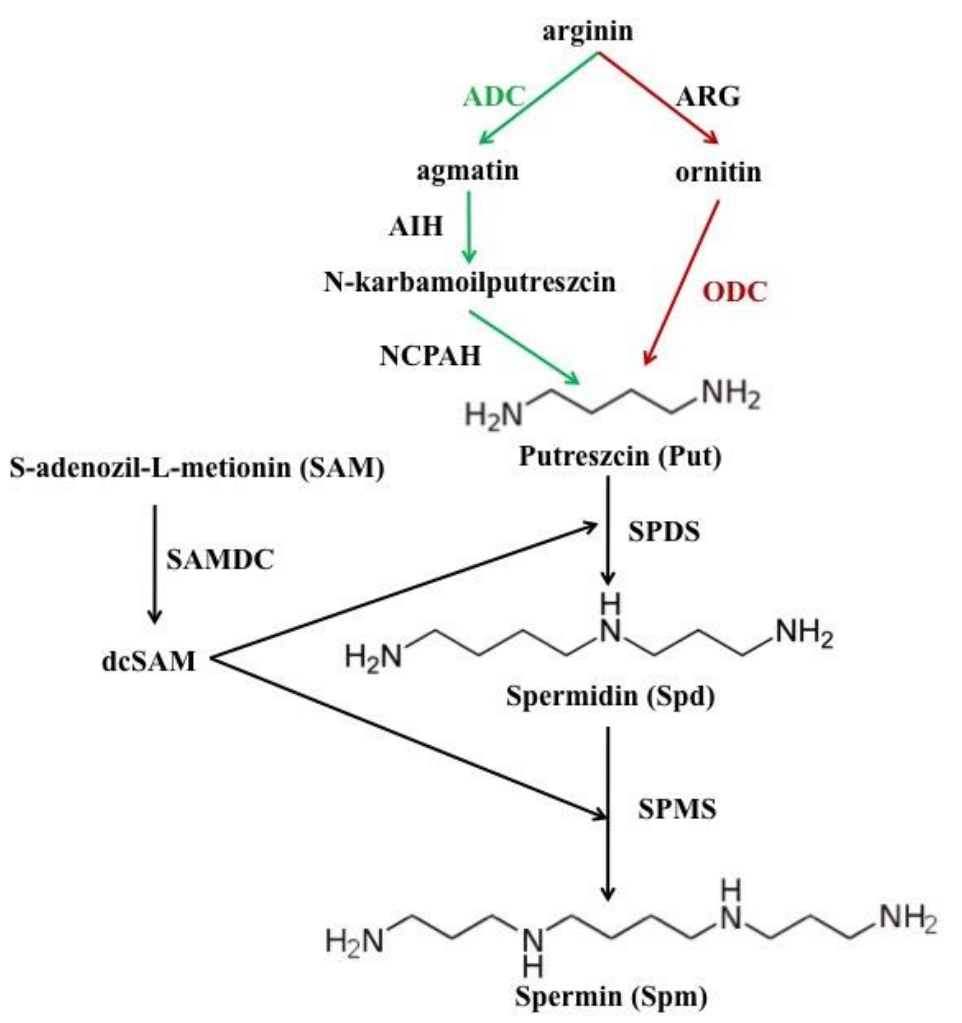

3. ábra: Poliaminok (Put, Spd, Spm) bioszintézisének sematikus ábrázolása [Kusano és Suzuki (2015) alapján módosítva].

ADC: arginin-dekarboxiláz; AIH: agmatin-iminohidroláz; ARG: argináz; dcSAM: dekarboxilált S-adenozil-Lmetionin; NCPAH: N-karbamoilputreszcin-amidohidroláz; ODC: ornitin-dekarboxiláz; SAMDC: S-adenozil-Lmetionin-dekarboxiláz; SPDS: spermidin-szintáz; SPMS: spermin-szintáz

Az ODC és ADC enzimeket kódoló gének növényfajonként változnak. Lúdfü növényekben az ODC gén hiányzik (Fuell és mtsai., 2010). Habár a legtöbb növényben az ADC enzimet egy gén kódolja, a keresztesvirágúak (Brassicaceae) családján belül két paralóg gén ( $A D C l$ és $A D C 2)$ található eltérő expressziós mintázattal (Hummel és mtsai., 2001). Lúdfüben az egyik $A D C$ gén kiütése nem jár jelentős fenotípusos változással, azonban mindkettő gén lecsendesítése letálisnak bizonyult embrió korban, ami az ADC és ezáltal a Put nélkülözhetetlen szerepét mutatja a növények túlélésében (Urano és mtsai., 2005; Liu és mtsai., 2006). A lúdfü genom négy $S A M D C$, két $S P D S$ és egy $S P M S$ gént kódol (Fuell és mtsai., 2010). Az SPDS és SPMS enzimek citoplazmatikus és sejtmagi lokalizáltságot mutatnak, míg a SAMDC enzim a legtöbb esetben a citoplazmában található (Belda-Palazón és mtsai., 2012). Csak az egyik SPDS gén elcsendesítése nem járt jelentős fenotípusos változással, míg mindkét gén kiütése szintén letálisnak bizonyult embrió korban, ami az Spd Put-hoz hasonló fontosságát mutatja (Imai és mtsai., 2004a). Ezzel szemben, ha kiütötték az SPMS gént lúdfüben, kontroll 
körülmények között nem mutatott fenotípusos változást, ami azt bizonyítja, hogy az Spm nem esszenciális az élethez (Imai és mtsai., 2004b).

A sejt túlélését vagy halálát azonban nemcsak a PA-ok mennyisége, hanem a lebontásukat végző enzimek aktivitása, valamint az általuk katalizált reakciótermékek mennyisége is befolyásolhatja. A PA-ok ugyanis könnyen képesek kijutni az apoplasztba (stressz hatására vagy a HR során), ahol degradációjuk következtében melléktermékként olyan fontos szignálmolekula keletkezhet, mint a $\mathrm{H}_{2} \mathrm{O}_{2}$ (Moschou és mtsai., 2008a).

\subsubsection{A poliaminok lebontása}

A PA-ok lebontásában a DAO (EC 1.4.3.6) és a PAO (EC 1.5.3.3) enzimek vesznek részt (Tavladoraki és mtsai., 2012). A DAO enzimek réztartalmú prosztetikus csoportot tartalmazó, 80-90 kDa molekulatömegü homodimerek, melyek elsősorban a diaminok (Put és a Cad) lebontását végzik, de egyes izoenzimeik kis mennyiségben egyes fajokban elfogadhatják az Spd-t és Spm-et is (Moschou és mtsai., 2012; Planas-Portell és mtsai., 2013). A DAO enzim a Put-ot a primer aminocsoportjánál oxidálja, ezáltal 4-aminobutanallá alakítja, amely spontán módon tovább alakulhat $\Delta^{1}$-pirrolinná. Melléktermékként ammóniumion $\left(\mathrm{NH}_{4}{ }^{+}\right)$és $\mathrm{H}_{2} \mathrm{O}_{2}$ keletkezik (4. ábra) (Kusano és Suzuki 2015).

A flavin-adenin-dinukleotid (FAD) tartalmú PAO enzimek az Spd és az Spm lebontását végzik. A növényekben a PAO enzimek által katalizált reakció szerint két típust különítünk el: az első típus a PA-ok terminális katabolizmusát, míg a másik a PA-ok egymásba történő visszaalakítását katalizáló "back conversion" reakciót látják el. Az első csoportba tartozó PAO enzimek az Spd és Spm N5 pozíciójú nitrogénjének endo oldalán található szénatomot oxidálják, melyhez elektron donorként molekuláris oxigént használnak, mely reakció során 4-aminobutanol vagy (3-aminopropil)-4-aminobutanol, 1,3 diaminopropán (DAP), melléktermékként pedig $\mathrm{H}_{2} \mathrm{O}_{2}$ keletkezik (Moschou és mtsai., 2012; Liu és mtsai., 2014) (4. ábra). Ezzel szemben a második csoportba tartozó PAO enzimek az Spd és Spm N5 pozíciójú nitrogénjének exo oldalán található szénatomon oxidálnak, mely reakció során az Spm-ből Spd vagy az Spd-ből Put, valamint 3-aminopropanol és melléktermékként szintén $\mathrm{H}_{2} \mathrm{O}_{2}$ keletkezik. Ezek a PAO enzimek föleg a PA-ok visszaalakítását "back conversion" és nem a terminális lebontásukat katalizálják (Moschou és mtsai., 2012; Mo és mtsai., 2015) (4. ábra). 

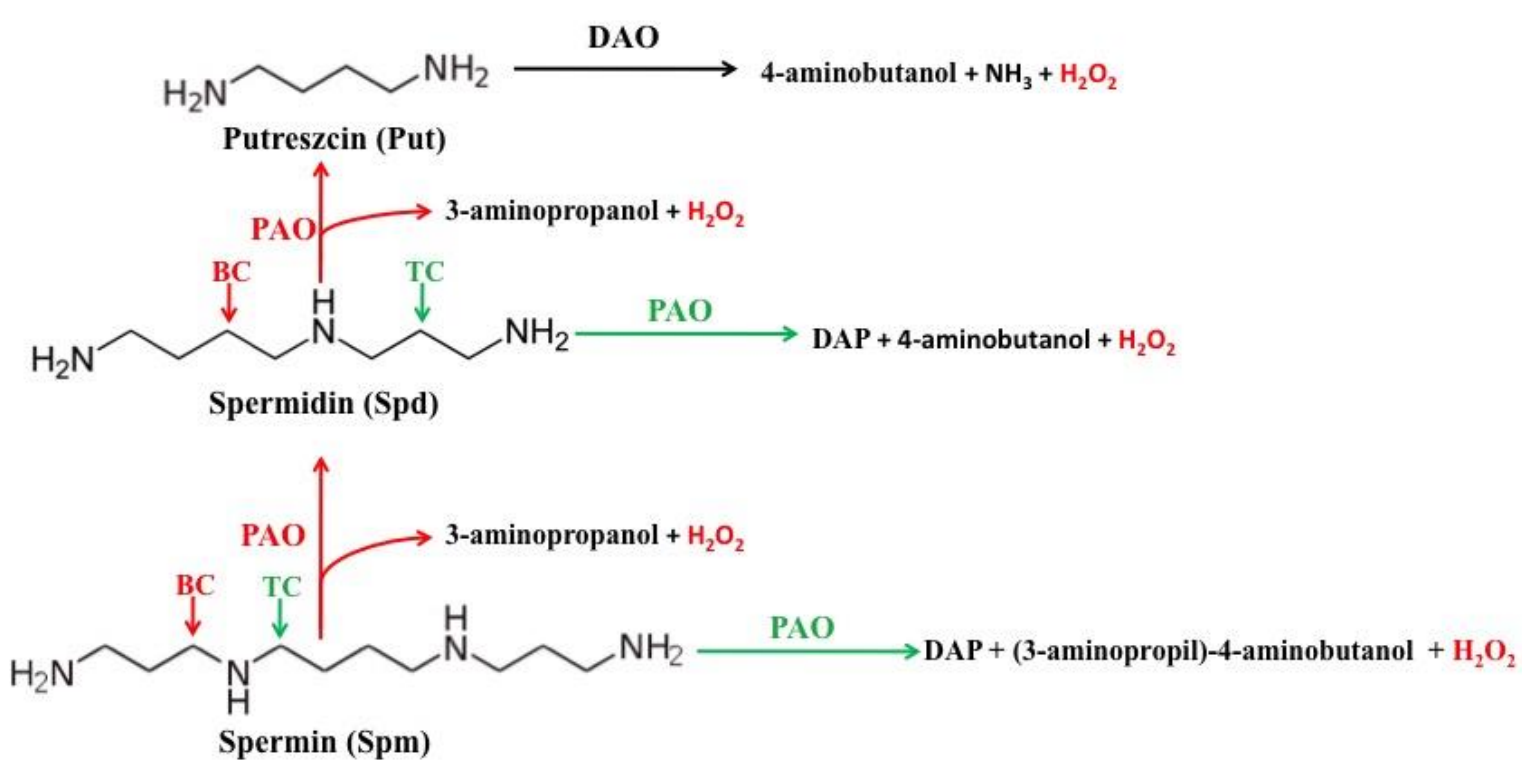

4. ábra: A putreszcin, spermidin, spermin katabolizmusának sematikus ábrázolása [Kusano és Suzuki (2015) alapján módosítva].

BC: Back conversion (piros vonallal jelölt); TC: végoxidáció (terminális katabolizmus, zöld vonallal jelölt). DAO: diamin-oxidáz; DAP: 1,3 diaminopropán; PAO: poliamin-oxidáz.

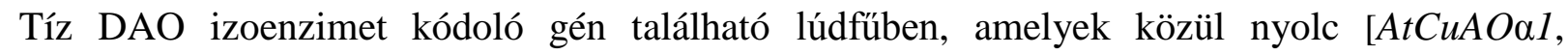

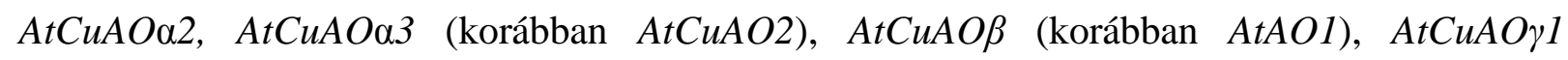

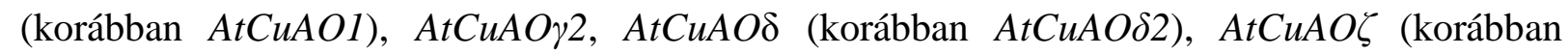
AtCuAO3 vagy AtCuAO1)] kódol funkcionális DAO-t (Tavladoraki és mtsai., 2016), azonban ezek közül ezidáig csak 4 izoenzimet jellemeztek: $A t C u A O \gamma 1$ és $A t C u A O \beta$ apoplasztikus, míg az $A t C u A O \alpha 3$ és $A t C u A O \zeta$ peroxiszómális lokalizáltságú fehérjéket kódol (Planas-Portell és mtsai., 2013; Naconsie és mtsai., 2014; Tavladoraki és mtsai., 2016). Az AtCuAO $\beta$ izoenzim csak a Put, míg az $A t C u A O \gamma 1, A t C u A O \alpha 3, A t C u A O \zeta$ a Put és Spd oxidációjában játszik szerepet (Planas-Portell és mtsai., 2013). Az izoenzimeket kódoló gének eltérő expressziós

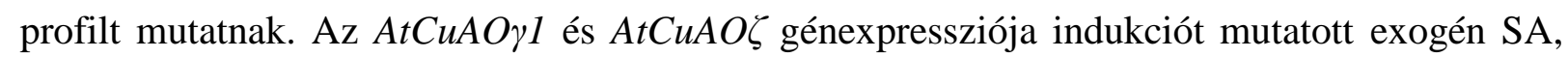
metil-jázmonát (MeJA), flagellin (patogén elicitor a növényi általános védekezési rendszer beindítására) kezelés hatására, míg az ET bioszintézisében fontos 1-aminociklopropán-1karbonsav (ACC) nem okozott szignifikáns változást. Ezzel szemben az AtCuAO 3 expressziója csak a MeJA kezelés hatására indukálódott (Planas-Portell és mtsai., 2013).

Öt PAO izoenzimet kódoló gén található a lúdfü genomban (AtPAO1-AtPAO5) (Takahashi és mtsai., 2010). Ezek közül ezidáig 4 fehérjét (AtPAO1-AtPAO4) jellemeztek (Moschou és mtsai. 2008b; Takahashi és mtsai. 2010; Fincato és mtsai. 2011). Az AtPAO1, AtPAO3 és AtPAO4 a katalizált reakciót tekintve is a PA-ok visszaalakítását katalizálja (Tavladoraki és mtsai. 2006; Moschou és mtsai. 2008b; Moschou és mtsai. 2012). Az AtPAO1 és AtPAO5 citoszolikus, AtPAO2, AtPAO3 és AtPAO4 peroxiszómális lokalizáltságot mutat 
(Tavladoraki és mtsai., 2016). Ezzel szemben apoplasztikus lokalizáltságot mutat az árpában és a kukoricában megtalálható PAO (Cervelli és mtsai., 2001; Cona és mtsai., 2006). Kimutatták, hogy az AtPAO1 az Spm-et oxidálja Spd-vé, továbbá, hogy kis mértékben, de előállít DAP-ot az Spm oxidációja során, amely azt bizonyítja, hogy ez az enzim a visszaalakító aktivitása mellett az Spm terminális katabolizmusában is részt vesz (Tavladoraki és mtsai., 2006). Az AtPAO5 enzimet kódoló génben hiányos lúdfü mutánsok megemelkedett Therm-Spm és Spm szinteket mutatnak, amelyek az enzim szubsztrátjaként szolgálhatnak (Zarza és mtsai., 2017). $\mathrm{Az}$ összes peroxiszomális lokalizáltságú PAO enzim "back conversion" aktivitással rendelkezik, azonban különböző a PA-okhoz való specifitásuk. Az AtPAO2 és AtPAO3 az Spm-et oxidálja Put-ra Spd intermedieren keresztül, míg az AtPAO4 kevesebb Put-ot állít elő az Spm oxidációja során (Sequera-Mutiozabal és mtsai., 2016). Növényekben csak az AtPAO3 mutat konstitutív expressziót, míg az AtPAO1 alacsony szinten expresszálódik (Tavladoraki és mtsai., 2006; Moschou és mtsai., 2008b). Az AtPAO2 a Put, Spd és Spm által negatívan szabályozott egy 5'-UTR szekvenciában található uORF-en keresztül. A PAO transzkriptum összehasonlító elemzése kimutatta, hogy az uORF szekvencia konzervált régió (GuerreroGonzález és mtsai., 2014).

A lebontást végző enzimek közül a PAO enzim az egyik kulcseleme az oxidatív robbanásnak, ami PCD-t indukálhat (Kim és mtsai., 2013). A meglehetősen magas PAO enzim aktivitás a differenciálódó trachea elemekben és a gyökérsüvegben megerösítheti azt az elképzelést, hogy a PAO enzimeknek közvetlenül van szerepük a PCD-ben (Tisi és mtsai., 2011). A PAO enzim kontroll körülmények közötti indukciója kismértékű $\mathrm{H}_{2} \mathrm{O}_{2}$ koncentráció emelkedést okozott transzgénikus dohány növényekben, amely a KAT, SOD, APX és POD enzimek indukcióját eredményezte, hozzájárulva a sejtek túléléséhez és a növények normális növekedéséhez. Azonban stressz körülmények között ez az aktivációs mechanizmus nem bizonyult elegendőnek a növények túléléséhez (Moschou és mtsai., 2008c). Patogén támadás során a PA-ok katabolizmusában szerepet játszó enzimek aktivitásának emelkedése különösen fontos az ellenálló fajtákban, továbbá azok a transzgénikus növények, amelyek folyamatosan expresszálják a PAO enzimeket kódoló géneket nagyobb toleranciát mutatnak a patogénekkel szemben (Yoda és mtsai., 2006; Moschou és mtsai., 2008b; 2009). Az apoplasztikus lokalizáltságú DAO és $\mathrm{PAO}$ enzimek, mint például a lúdfüben található AtCuAO1 és a kukorica ZmPAO1 hozzájárulnak az apoplasztikus oxidatív robbanás, valamint a HR kialakításához, amely végső soron a kórokozokkal szembeni rezisztencia kialakításában játszik fontos szerepet (Planas-Portell és mtsai., 2013). A PA-ok szintjének fenntartásában tehát fontos szabályozó szerepe van a bioszintézis és a lebontásuk egyensúlyának. Mindemelett a DAO és PAO enzimek aktivitásai kulcsfontosságú szereppel bírhatnak a különböző stresszválaszok 
kialakításában, így különösen a biotikus stresszfolyamatokban, mivel szerepük lehet az oxidatív és nitrozatív stressz során is (Pottosin és mtsai., 2014).

\subsubsection{A poliaminok oxidatív és nitrozatív stresszben betöltött szerepe}

A PA-ok antioxidánsként is fontos szerepet játszhatnak, ugyanis javíthatják az életképességet, csökkenthetik a $\mathrm{H}_{2} \mathrm{O}_{2}$ indukálta PCD kialakulását, valamint oxidatív stressz alatt indukálhatják az antioxidáns enzimek, ugy mint a SOD, KAT, POD aktivitását is a különböző növényekben (Xu és mtsai., 2011; Shu és mtsai., 2013; Mostofa és mtsai., 2014). Exogén PA kezelések és például az Spd vagy a PA-ok bioszintézisét kódoló gének túlexpresszáltatása képes antioxidáns enzimeket kódoló gének expresszióját is indukálni (Tanou és mtsai., 2014; Zhang és mtsai., 2015). A szabad PA-ok a $\cdot \mathrm{O}_{2}{ }^{-}$és a $\mathrm{H}_{2} \mathrm{O}_{2}$, míg a kötött formák az egyéb ROS-ok eliminálásában játszanak szerepet, ami elsősorban az anionkötési képességükre vezethető vissza (Kubi és mtsai., 2005; Groppa és Benavides 2008). A PA-ok apoplasztba történő transzportja és lebontódása által keletkezett $\mathrm{H}_{2} \mathrm{O}_{2}$ kiváltja a MAPK aktivációját is (Kusano és mtsai., 2008), továbbá a keletkezett $\mathrm{H}_{2} \mathrm{O}_{2}$ a Fenton reakción keresztül átalakulhat $\mathrm{OH}$ gyökké is, amelynek sejtkárosító hatása lehet (Pottosin és mtsai., 2014). A szabad PA-ok, köztük az Spd koncentrációtól függő módon aktiválhatja a NOX enzim müködését, ily módon befolyásolva a $\mathrm{O}_{2}{ }^{-}$keletkezését, míg a Put kivédheti a PAO által generált $\mathrm{H}_{2} \mathrm{O}_{2}$ indukálta PCD kialakulását (Andronis és mtsai., 2014; Moschou és mtsai., 2014). Ugyanakkor az endogén Spd és Spm/Put szintek egymáshoz viszonyított sejten belüli aránya is kritikus fontosságú a növények stressztürésének a javításában (Hu és mtsai., 2012). A megnövekedett Spd és Spm szintek ugyanis hatékonyak a $\mathrm{ROS}$, különösen a ${ }^{\circ} \mathrm{O}_{2}{ }^{-}$eltávolításában, valamint fontos szerepet játszanak a PM integritásának fenntartásában azáltal, hogy megakadályozzák a $\cdot \mathrm{O}_{2}{ }^{-}$generációját (Roussos és Pontikis 2007), továbbá gátolják proteázok és RNázok aktivitását is (Wallace és mtsai., 2003). A PA-ok képesek depolarizálni a PM-et, ezáltal növelik a PM vezetőképességét és az ionok kiáramlását a sejtekből (Pottosin és Shabala 2014).

A PA-ok képesek kölcsönhatásba lépni fontos szabályozó fehérjékkel, például a 14-3-3 fehérjével (Garufi és mtsai., 2007). Képesek csökkenteni a nitrátasszimilációt és ezáltal az NO nitritből történő termelődését is a 14-3-3 fehérjével történő kölcsönhatásuk révén (Athwal és Huber 2002). A Put 14-3-3 fehérjéhez való kötődése következtében az NR inaktivációja következhet be (Rosales és mtsai., 2012). A PA-ok indukálhatják az NO termelödését is, aminek fontos szerepe lehet a stresszválaszok és más stresszközvetítök közötti kapcsolat megteremtésében (Arasimowicz-Jelonek és mtsai., 2009; Scheler és mtsai., 2013). Az Spd és az Spm például gyors, néhány percen belüli NO képződést indukál lúdfü gyökércsúcsok 
elongációs zónájában, valamint az alsó levelekben, különösképpen az erekben és a trichómákban (Tun és mtsai., 2006; Pál és mtsai., 2015), amely hatás nem jelentkezik, ha a növényeket az állati NOS enzimre ható gátlószerrel, a 2-aminoetil-2-tiopszeudoureával (AET) vagy cPTIO-val kezelik. Gémes és mtsai. (2011) kimutatták, hogy exogén Spd és Spm kezelés növelte az NO termelődését paradicsom levél protoplasztokban. Exogén Put kezelés is képes növelni az NO mennyiségét szója sejtszuszpenzióban (Yang és mtsai., 2014). Az NO hatása elősegítheti vagy gátolhatja a PCD-t többek között a fehérjék S-nitrozilációján keresztül, amely nagyban függ számos faktortól, mint például a sejt típusától, a celluláris redox állapottól, valamint az NO helyi koncentrációjától (Wang és mtsai., 2010a). Ezidáig 271 PA-ok által indukált S-nitrozilációra hajlamos fehérjét (Tanou és mtsai., 2014), köztük az FeSOD-ot sikerült azonosítani (Wimalasekera és mtsai., 2011a).

Az argininből ornitint előállító ARG enzimet kódoló gén kiütése szignifikánsan növelte a PA-ok és az NO mennyiségét, amely növelte a lúdfü növények só-stresszel szembeni toleranciáját, valamint indukálta a hajtás és gyökér fejlődését. Ezzel szemben, ha az ARG enzimet túlexpresszáltatták, csökkent PA felhalmozódást és NO termelődést tapasztaltak, bizonyítva az arginin metabolizmus PA-ok és NO szintekben és a növényi stresszválaszok kialakításában betöltött fontosságát (Shi és mtsai., 2013; Meng és mtsai., 2015).

Nemcsak a PA-ok bioszintézisében szerepet játszó enzimek, de a lebontást végző enzimek is képesek befolyásolni a ROS és az NO mennyiségét. Az AtPAO3 és a NOX aktivitása között átfedő kapcsolat figyelhető meg, amely hatással lehet a ROS mennyiségére és a respirációra is lúdfü növényekben (Andronis és mtsai., 2014). Lúdfü AtCuAO1 és az AtPAO2 részt vesz a PA- és/vagy az abszcizinsav (ABA)-indukálta NO termelődésében is (Wimalasekera és mtsai., 2011b; Wimalasekera és mtsai., 2015). Ezzel párhuzamosan a lúdfüben megtalálható $\mathrm{CuAO} 8$ enzim hiánya csökkent $\mathrm{NO}$ mennyiséget és megemelkedett ARG enzim aktivitást okozott (Groß és mtsai., 2017). A lebontás során keletkezett $\mathrm{H}_{2} \mathrm{O}_{2}$ termelődéssel párhuzamosan az NO szintézise is kapcsolódhat a PA-ok DAO és PAO enzimek általi lebontásához (Wimalasekera és mtsai., 2011a). A $\mathrm{H}_{2} \mathrm{O}_{2}$ vagy az SNP kezelés képes indukálni antioxidáns enzimek, úgy mint a SOD, KAT, APX aktivitását, csökkentve a karbonilált és növelve az S-nitrozilált fehérjék mennyiségét, amely a különböző jelátviteli utak az NO és a $\mathrm{H}_{2} \mathrm{O}_{2}$ által közvetített kölcsönhatását mutathatja (Tanou és mtsai., 2009a; b). 


\subsubsection{A poliaminok és a szalicilsav kapcsolata}

A PA-ok metabolizmusa fitohormonok, mint például az SA által szabályozott (JiménezBremont és mtsai., 2014). Habár az SA szerepe a növények biotróf patogénekkel szembeni rezisztencia kialakításában már jól ismert (Hayat és mtsai., 2010), jelenlegi információink az SA és a PA-ok metabolizmusa közötti kapcsolatról még csak részben felderített. Exogén SA kezelés hatására PA-ok felhalmozódása figyelhető meg kukoricában (Németh és mtsai., 2002) és paradicsomban (Szepesi és mtsai., 2009), míg exogén Spd vagy Spm elökezelés növelte az SA endogén mennyiségét búza (Triticum aestivum L.) szemekben (Iqbal és Ashraf 2006). Továbbá exogén Spm kezelés képes növelni az SA-indukált protein kinázok (SIPK) és a sérülés indukált protein kinázok (WIPK) relatív trasnzkript szintjét, ami mitokondriális disszfunkciót okoz dohány növényekben (Takahashi és mtsai., 2003). Másrészről az SIPK és WIPK képes a PA-ok, különösen a Put mennyiségét növelni a bioszintézisében szerepet játszó gének transzkripcionális szabályozásán keresztül (Jang és mtsai., 2009). Exogén SA kezelés képes a PA-ok bioszintézisében és lebontásában szerepet játszó enzimek gén expresszióját és aktivitását koncentrációtól függő módon szabályozni (Wang és mtsai., 2012; Pál és mtsai., 2015). Az SA többek között indukálhatja az $A D C$ és $O D C$ gének expresszióját paradicsom növényekben (Zhang és mtsai., 2011). A lebontásban szerepet játszó AtCuAOl gén SA, az AtCuAO2 MeJA, míg az AtCuAO3 gén expressziója mindkét hormon által szabályozott (Planas-Portell és mtsai., 2013). A biotikus stressz során az SA-nak fontos szerepe van a DAO és PAO enzimeket kódoló gének expressziójának szabályozásában is. A patogénekkel szembeni ellenállóság ugyanis függ a $\mathrm{HR}$ aktiválásától, mivel a $\mathrm{HR}$ egyik kulcslépése a $\mathrm{H}_{2} \mathrm{O}_{2}$ koncentrációjának emelkedése, melyhez feltételezhetően a PA-ok lebontásában szerepet játszó enzimek aktivitásának emelkedése is nagymértékben hozzájárulhat (Jimenez-Bremont és mtsai., 2014). Mind a terminális katabolizmus, mind pedig a "back conversion" mellékterméke a $\mathrm{H}_{2} \mathrm{O}_{2}$, mely esszenciális szerepet játszik biotikus stressz során, azonban a citoplazmatikus $\mathrm{H}_{2} \mathrm{O}_{2}$ mennyiségének emelkedése gátolhatja az NPR1 sejtmagba történő transzlokációját, ezáltal pedig a $P R$ gének expresszióját is (Peleg-Grossman és mtsai., 2010). A PAO enzim túlexpresszáltatása a MAPK kaszkád aktivációját okozta biotikus stressz során (Moschou és mtsai., 2009). Prabhavathi és Rajam (2007) a PA-ok bioszintézisének és katabolizmusának együttes emelkedését feltételezi biotikus stressz során, mivel zab (Avena sativa) ADC gént túlexpresszáló padlizsán (Solanum melongena) növényekben a megnövekedett ADC enzim aktivitás megnövekedett DAO enzim aktivitással járt, mely egy összefüggő rendszer meglétét mutatja. 
Ugyanakkor a PA-ok mennyiségét és metabolizmusát nemcsak az SA, hanem a növények növekedésében és fejlődésében, valamint a biotikus stresszfolyamatokban ugyancsak fontos szerepet játszó hormon, az ET is nagymértékben befolyásolhatja (Agudelo-Romero és mtsai., 2013).

\subsection{Az etilén}

Az ET a növények növekedését és fejlődését befolyásoló, az öregedést és a levelek leválását serkentő, gáz halmazállapotú hormon, amely mint szignálmolekula fontos szerepet játszik a növények stresszfolyamataiban is (van de Poel és van Der Straeten 2014; Yang és mtsai., 2015a).

Az ET bioszintézis prekurzora a metionin, ami a SAM szintáz (EC 2.5.1.6), más néven metionil-adenozil transzferáz (MAT, EC 2.5.1.6) enzim katalitikus aktivitásának következtében SAM-á alakul. A citoplazmában, a SAM ACC-vé történő átalakulását az ACC szintáz (ACS, EC 4.4.1.14) enzim katalizálja. Az ACC-ből történő etilénképződést az ACC oxidáz (ACO, EC 1.14.17.4) enzim végzi (Bulens és mtsai., 2014). Az ET szintézisét a különböző hormonok eltérő módon szabályozzák. Az ACS gének indukcióján keresztül az ET szintézisét serkenti a JA, míg az SA képes gátolni az ACC ET-vé történő átalakulását azáltal, hogy az ACO enzim müködését gátolja (Bali és mtsai., 2017). Más rendszerekben az SA serkentheti az ET szintézisét. Fan és mtsai. (2010) leírták, hogy az NO mind az ACS mind pedig az ACO enzimek aktivitásán keresztül gátolja a SAM átalakulását ACC-vé, szabályozva ezzel az ET mennyiségét. Ezzel szemben, Magalhaes és mtsai. (2000) megnövekedett ET termelődést tapasztaltak, ha a lúdfü növényeket NO-val kezelték bizonyítva, hogy az NO eltérő módon hat az ET bioszintézisére.

Az ET receptorok, az "ethylene receptor" 1 és 2 (ETR1, ETR2), az "ethylene insensitive" 4 (EIN4) és "ethylene response sensors" 1 és 2 (ERS1, 2) ER lokalizáltságot mutatnak lúdfü növényekben. A receptorok $\mathrm{Cu}$ (I) iont tartalmazó dimerizálódott proteinek, amelyek a bakteriális kétkomponensü hisztidin kinázokhoz hasonlóak. A paradicsomban található ETR3 (NEVER-RIPE, NR) génje jelfogó domén nélküli ET receptort kódol, amely a lúdfü ETR1 génjével mutat homológiát. Irodalmi adatokból tudjuk, hogy az ET indukálta válaszok az ER lokalizált receptorok által negatív szabályozás alatt állnak (Wang és mtsai., 2013). Az ET kötődése után a receptorok deaktiválódnak, aminek hatására az ETR1-gyel kapcsolatban lévő, a jelátvitel újabb negatív regulátora a "constitutive triple response" 1 (CTR1) Ser/Thre kináz konformációja megváltozik, majd inaktiválódik (Zhong és mtsai., 2008). A CTR1 az emlős Raf Ser/Thre protein kinázokkal mutat homológiát, amely aktív 
állapotban transzkripciós faktorokat és effektor fehérjéket dezaktivál. A lúdfü genomban öt ET receptort és egy CTR1-gyet, míg paradicsomban hat ET receptort és három CTR1-gyet azonosítottak (Klee és Tieman 2002; Chen és mtsai., 2010). A CTR1 inaktiválódása során az ET jelátvitel további komponensei felszabadulnak a gátlás alól, ezek az EIN2 transzmembrán fehérje (Ju és mtsai., 2012), valamint az őt követő, primer ET válaszgéneket aktiváló EIN3 és EIN-like 3 (EILs) transzkripciós faktorok (Ji és Guo 2013). Az EIN3 transzkripciós faktor dimer formában kötődik az "ethylene response factor" 1 (például ERF1) ET válaszgének és az ET válaszban szerepet játszó transzkripciós faktorok promoteréhez, majd az újonnan szintetizálódó ERF1 transzkripciós faktor a szekunder válaszgének ET-specifikus GCC elemeihez kötődik és transzkripciót indukál (Cheng és mtsai., 2013). Az ET válaszgének (pl. PLANT DEFENSIN1,2) kódolják azokat a fehérjéket, amelyek az ET által indukált különböző védelmi reakciókban vesznek részt (Müller és Munné-Bosch 2015).

Az ET emelheti a ROS termelödését is (Wang és mtsai., 2010b), amely koncentrációtól függő módon DNS fragmentációhoz és sejthalálhoz vezethet (De Jong és mtsai., 2002). Ezzel párhuzamosan az ET bioszintézisében mutáns transzgénikus dohány, valamint az ET inszenzitív (ein2-5) és ET szenzitív (ctr1-1) lúdfü növények csökkent ROS felhalmozódást mutattak az antioxidáns enzimek expressziójának és aktivitásának (MnSOD, Cu/ZnSOD és KAT) növekedése miatt (Wi és mtsai., 2010; Lin és mtsai., 2012).

\subsubsection{Az etilén és a poliaminok közötti kölcsönhatás}

Az ET és a PA-ok szeneszcenciában, valamint PCD-ben betöltött szerepe között ellentétes hatás figyelhető meg (Müller és Munné-Bosch 2015), ugyanis míg a PA-ok gátolhatják, addig az ET indukálhatja a szeneszcenciát (Pál és mtsai., 2015). A sejthalál a PA-ok keletkezésének és lebontásának arányától is függ: amikor a PA-ok szintézise gyorsabb, mint a lebontása, akkor a sejthalál kivédhető, ellenkező esetben azonban PCD alakulhat ki (Moschou és mtsai., 2008a). A szabad PA-ok közül az Spd/Spm és az ET között kompetitív kapcsolat állhat fent, mivel mindkét molekula bioszintézisének közös prekurzora a SAM. A PA-ok képesek gátolni az ACC szintáz transzkript szintjének felhalmozódását (Harpaz-Saad és mtsai., 2012), továbbá gátolják az ACS enzim aktivitását is (Cassol és Mattao 2003). Ugyanakkor az ET is képes gátolni az ADC és SAMDC aktivitását (Anwar és mtsai., 2015). Az ET-indukálta $\mathrm{H}_{2} \mathrm{O}_{2}$ termelődésében a PAO enzim is részt vehet az AtPAO2 és AtPAO4 transzkript szintjének és ezáltal a PAO enzim aktivitásának emelkedésén keresztül lúdfü zárósejtekben (Hou és mtsai., 2013). Azonban az ET és a PA-ok metabolizmusa közötti kapcsolat vizsgálata az irodalom alapján még hiányosnak és ellentmondásosnak mondható. Ugyanis exogén PA kezelés a PA-ok 
bioszintézisében szerepet játszó enzimek aktivációján keresztuil számos növényi szövetben gátolta az ET termelődését (Cassol és Mattoo 2003; Harpaz-Saad és mtsai., 2012). Az ET termelődése és az Spd/Spm-hez viszonyított aránya egy érés specifikus E8 promóterrel kapcsolt élesztő $S A M D C$ gént (E8:ySAMDC) túlexpresszáló paradicsom növényben magasabb volt (Mehta és mtsai., 2002), melynek hátterében a megnövekedett ACS transzkript szintje állt (Mattoo és mtsai., 2007). Megnövekedett Spd tartalmakat és ET termelődést kaptak paradicsomban, ha az élesztő SPDS génjét expresszáltatták túl hasonló érés specifikus promoterrel (Nambeesan és mtsai., 2010), ami azt bizonyítja, hogy in vivo a SAM elérhető mennyisége nem sebességkorlátozó az ET vagy az Spd/Spm bioszintézisében, továbbá, hogy mindkét útvonal egyidejüleg is müködhet. Hasonló eredményt kaptak sötét indukálta szeneszcencia folyamatában árpa levél sejtekben is (Sobieszczuk-Nowicka és mtsai., 2016). Megnövekedett ACS transzkript szintet mértek SPMS gént túlexpresszáló (35S:AtSPMS-9) transzgénikus lúdfü növényekben is (Gonzalez és mtsai., 2011), azonban, ha a Put-ot akkumuláltatták túl 35S:AtADC2 transzgénikus növényekben, csökkent ACS6 transzkript szintet kaptak (Alcázar és mtsai., 2005). Azonban további ET és PA mutánsokkal végzett kísérletekre van még szükség az ET és a PA-ok metabolizmusa közötti összes kapcsolat feltérképezésére.

\subsection{A fény és sötétség hatása a növények stresszfolyamatában szerepet játszó molekulákra}

A növények védekezési reakciója a patogénekkel szemben nagyban függ a környezeti faktoroktól, a hőmérséklettől, a vízellátottságtól, a páratartalomtól, valamint a fénytől (Roden és mtsai., 2009; Suzuki és mtsai., 2014). A fénynek, mint elsődleges energiaforrásnak fontos szerepe van a növényi immunválasz kiváltásában, de a patogénekkel szembeni védekezési válaszok aktivációja is fényfüggő folyamat (Karpiński és mtsai., 2003; Kangasjarvi és mtsai., 2012). A növények képesek érzékelni a fény mennyiségét, minőségét, a besugárzás időtartamát és irányát, valamint a fény/sötét ciklusok változását is (Delprato és mtsai., 2015). A fény hiánya, azaz az éjszakai periódus vagy a hosszabb ideig tartó sötétség megváltoztathatja a növények fényfüggő védelmi mechanizmusait, hiszen új, fitohormonok és egyéb szabályozó molekulák által regulált jelátviteli utakat aktivál (Ballaré 2014). Ennek következtében a különböző környezeti ingerekre adott növényi válaszok eltérőek lehetnek fényben és sötétben. 


\subsubsection{Az SA és a fény/sötét kezelés kapcsolata}

A fény kulcsszerepet játszik az SA-indukálta folyamatokban, a HR és a SAR kialakításában (Karpiński és mtsai., 2003). A megvilágítás hossza döntő jelentőségü lehet a növények védekezési folyamataiban (Hua 2013). Pseudomonas syringae pv.maculicola-val történő nappali fertőzés során a kórokozó elicitor molekulájához (AvrRpm1) kapcsolt effektor védelmi válaszok kialakulása, az SA felhalmozódása és a HR erőteljesebbek, mint ha a fertőzés éjszaka történne (Griebel és Zeier 2008). Ha azonban a növényeket sötét periódusban fertőzték nem gazda és avirulens patogénekkel, akkor a HR szignifikáns csökkenést mutatott, mely eredményeképpen csökkent méretü foltok alakultak ki a növények levelén, feltételezhetően az SA fényfüggő felhalmozódása miatt (Mateo és mtsai., 2004; Chandra-Shekara és mtsai., 2006). A megvilágítási időtartamának hatását a SAR-ra a MeSA mennyiségében való eltéréssel magyarázzák (Liu és mtsai., 2011). A MeSA ugyanis szükséges a SAR kialakításához, amikor a növények kevés vagy semennyi fényt nem kapnak avirulens patogén fertőzés után. A $P R$ gének is fényfüggő expressziót mutattak lúdfü növények Pseudomonas syringae pv. maculicola fertőzése során (Zeier és mtsai., 2004). A fertőzést követő első órákban a fénynek ugyanis fontos szerepe van, hiánya negatívan befolyásolhatja a rezisztencia kialakulását (Griebel és Zeier 2008). Ugyanakkor Pseudomonas syringae-vel szembeni fogékonysága az esti órákban volt nagyobb a paradicsom növényeknek (Yang és mtsai., 2015b). A növények fényfüggő védekezése fotoreceptorok, úgy mint fitokrómok (PHYA-PHYE), kriptokrómok (CRY) és fototropinok indukálta jelátviteli folyamatok által is szabályozottak (Christie és mtsai., 2014).

Az irodalomból már ismert a fény abiotikus stresszekre gyakorolt hatása. Többek között képes gátolni a levelek légzését megemelkedett $\mathrm{CO}_{2}$ és szárazság stressz során (Crous és mtsai., 2012), valamint képes felgyorsítani a növényi válaszokat hőstressz alatt (De Frenne és mtsai., 2015). Azonban ezidáig még kevés tanulmány vizsgálta a fény és sötétség hatását az SA indukálta folyamatokra, különös tekintettel a ROS és az NO termelődésére és a PA-ok metabolizmusára.

\subsubsection{A ROS, NO és a fény/sötét kezelés kapcsolata}

A növények fényfüggő védekezése nemcsak a fotoreceptorok, hanem a fotoszintézis által is szabályozott (Roden és mtsai., 2009). A fény inztenzításának és lokálisan elérhető mennyiségének ugyanis meghatározó szerepe van a kloroplasztiszokra és a fotoszintetikus apparátus aktivitására, ezáltal közvetve a növényi immunitás kialakítására (Delprato és mtsai., 2015). Fény jelenlétében a kloroplasztisz és a peroxiszóma, míg sötétben a mitokondrium a fö 
forrása a ROS termelődésének (Choudhury és mtsai., 2013). A kloroplasztisz szerepet játszik a ROS és az NO termelődésében, valamint fontos szintézis helye az SA-nak (Kangasjärvi és mtsai., 2012). A kloroplasztiszhoz kapcsolt válaszok fényfüggő hatásának legalább három formáját különíthetjük el: (1) a fotoszintetikus elektrontranszportlánc redox státuszában bekövetkező változások, (2) ${ }^{1} \mathrm{O}_{2}$ (3) és egyéb ROS-ok úgy mint a $\mathrm{O}_{2}{ }^{-}$és $\mathrm{H}_{2} \mathrm{O}_{2}$ termelődésének növekedése (Delprato és mtsai., 2015). Fénystressz esetén a plasztokinon pool szabályozza a sejt redox állapotát, ezáltal a ROS mennyiségét, amely fontos szerepet játszik a sejthalál kiváltásában lúdfü növényekben (Mühlenbock és mtsai., 2008). Az SA fontos szabályozó hormon a kloroplasztikus ROS azon belül is a $\mathrm{H}_{2} \mathrm{O}_{2}$ mennyiségének meghatározásában (Mateo és mtsai., 2006). Azonban a HR okozta apoplasztikus oxidatív robbanás mellett a kloroplasztiszok is nagymértékben hozzájárulhatnak stressz során a ROS generáláshoz a fotoszintetikus elektrontranszportlác müködése közben. A fotoszintézis II. fotokémiai reakcióit követő töltésrekombináció után a triplet állapotú *P680 a gerjesztési energiát átadhatja ugyanis az oxigén molekulának, ami az igen reaktív ${ }^{1} \mathrm{O}_{2}$ keletkezéséhez vezethet. A fotoszintetikus elektrontranszport során a PSII fotokémiai rendszerben keletkező ${ }^{1} \mathrm{O}_{2}$ mellett a PSI is hozzájárul a ROS kialakulásához. A PSI közvetlenül elektronokat adhat át a molekuláris oxigénnek, ezáltal $\mathrm{O}_{2}^{-}$-t , majd ebből $\mathrm{H}_{2} \mathrm{O}_{2}$-ot generálva a kloroplasztiszban (Hideg és mtsai., 2002; Aro és mtsai., 2005). A ${ }^{1} \mathrm{O}_{2}$ és $\mathrm{H}_{2} \mathrm{O}_{2}$ fontos szerepet játszik a kloroplasztisz-sejtmag retrográd szignalizációban, ezáltal pedig a védelmi gének expressziójának szabályozásában (Karpiňski és mtsai., 2013), valamint szerepük van a HR kialakításában is (Cheng és mtsai., 2016).

A fotoszintézis patogénekkel szembeni védekezésben betöltött fontosságát mutatja a PSII felépítésében fontos szerepet játszó $\mathrm{S}$ alegységet (PsbS) és a violaxantin de-epoxidáz (VDE1) enzimet nem tartalmazó, nem fotokémiai kioltásban mutáns lúdfü növény ( $p s b S$ vel), mely csökkent választ mutatott a patogénekhez kapcsolható molekuláris mintázatok (PAMP) által kiváltott immunitásban (PTI - PAMP-triggered immunity) (Gohre és mtsai., 2012). Hasonló változások figyelhetők meg, ha a PSII fotokémiai rendszer öt különálló komponensét (PsbO, PsbQ, RuBisCO, FtsH, PDS) csendesítették el dohány növényekben. A fotoszintézis normális müködésének hiánya növelte a mutáns növények fogékonyságát a TMV fertőzéssel szemben (Manfre és mtsai., 2011).

A ROS termelődésében a NOX aktivitása is fontos szerepet játszik, ugyanis a NOX által generált apoplasztikus oxidatív robbanás előidézheti a kloroplasztikus ROS termelődését is (Joo és mtsai., 2005). Erős fény esetén a kloroplasztiszok a PM közelébe kerülnek, amely elősegíti a kompartmentek közötti jelátvitelt is (Shapiguzov és mtsai., 2012). 
Nemcsak a ROS termelődése, hanem az NO bioszintézisében is fontos szerepet játszó NR enzimet kódoló gének expressziója is fényfüggő aktivitást mutat. A fény jelenléte nemcsak a gének transzkripcióján keresztül indukálhatja az NR enzim aktivitását, hanem hatással van a transzláció szabályozásán keresztül a fehérje képződésére is (Melo és mtsai., 2016). Azonban ezidáig nem ismert, hogy exogén SA kezelés hogyan változtatja meg az NO termelődését fényben és sötétben. Összességében elmondható, hogy a megvilágítás minősége és időtartama képes megváltoztatni a különböző védelmi útvonalak és molekulák növényi immunitásban betöltött szerepét.

\subsubsection{Antioxidáns enzimek}

Az antioxidáns enzimek aktivitásában bekövetkező változások függnek a növényi szervtől, annak fejlődési állapotától, valamint a környezeti stresszorok fajtájától és azok intenzitásától (Das és Roychoudhury 2014). A különböző antioxidáns enzimek aktivitásának védelmi mechanizmusokban betöltött szerepét már több száz kutatási eredmény támasztja alá (Caverzan és mtsai., 2016), azonban ezidáig csak néhány tanulmány vizsgálta meg ezen enzimek aktivitásának és expressziójának változását sötétben vagy az éjszakai periódusban (LuschinEbengreuth és Zechmann 2016). Sötét periódusban a dohány FeSOD génjének kismértékü represszióját, míg a $M n S O D$ konstans transzkript szintjét mutatták ki (Dutilleul és mtsai., 2003). A totál SOD enzim aktivitása magasabb volt a késői órákban, míg az éjszaka folyamán aktivitása csökkent paradicsom növények leveleiben (Kerdnaimongkol és mtsai., 1997). Összeségében elmondható, hogy a SOD aktivitása nagymértékben függ az egyes izoenzimek aktivitásától, amelyek eltérő szabályozódást mutathatnak sötétben.

A $\mathrm{H}_{2} \mathrm{O}_{2}$ eliminálásában fontos szerepet játszó KAT enzimröl bebizonyosodott, hogy az enzim erősen fényérzékeny (Mhamdi és mtsai., 2012). A KAT izonezimeket kódoló gének expressziói nagymértékben függnek a növény fejlettségi állapotától, a környezeti tényezőktől és a fotoperiódustól, ugyanis transzkript szintjük cirkadián ritmust mutat (Mhamdi és mtsai., 2010). Lúdfüben a KAT2 expressziója a reggeli órákban, a KAT3 gén expressziója pedig az esti órákban mutatott indukciót (Michael és McClung 2002). Búzában a KAT2 expressziója fényben, míg a KAT1 expressziója sötétben indukálódott (Luna és mtsai., 2005). Rizsben a KATA génexpresszója a fény szakasz végén, míg a KATC génexpressziója sötétben mutatott szignifikáns indukciót (Joo és mtsai., 2014). A nap folyamán a dohány KAT1 relatív transzkript szintje folyamatosan csökkent, míg expressziója szignifikánsan növekedett a sötét periódus során. Ezzel szemben a KAT2 és KAT3 gének expressziói ellentétes indukciót és repressziót mutattak (Dutilleul és mtsai., 2003). Összességében megállapítható, hogy a KAT izoenzimeket 
kódoló gének expressziója és aktivitása nagymértékben függ a cirkadián ritmustól és az adott növényfajtól

A SOD és a KAT aktivitása mellett a fény az APX enzim aktivitását és expresszióját is befolyásolja. A citoszolban lokalizálódó dohány $c A P X 1$ mRNS szintje 16 órát követő sötétkezelés után szignifikánsan csökkent, míg mennyisége fényben szignifikánsan megemelkedett (Pignocchi és mtsai., 2003). Hasonlóan a dohányhoz a cAPX1 expressziója fényben indukciót, míg sötétben repressziót mutatott lúdfü növényekben (Kubo és mtsai., 1995). A dohány citoszolikus APX enzimhez hasonlóan a kloroplasztikus lokalizáltságú tAPX és sAPX izoenzimek aktivitása és relatív transzkript szintje is szignifikánsan csökkent sötétben (Dutilleul és mtsai., 2003). Összességében elmondható, hogy az APX enzim aktivitása a fényperiódusban mutat szignifikáns emelkedést, míg sötétben csökken (Cheng és Ma 2004).

\subsubsection{A poliaminok és az etilén}

Nemcsak az SA felhalmozódása és az általa indukált folyamatok, de a PA-ok és az ET metabolizmusa is fényfüggő aktivitást mutatnak. Lúdfüben az ET kifejeződése napszakos ingadozást mutat. Az ET termelődését befolyásolja a cirkadián óra, azonban az ET bioszintézis és jelátviteli mutánsok esetében a cirkadián rendszer zavara nem figyelhető meg (Thain és mtsai., 2004). A fény növényfajtól, szövettípustól és fejlődési állapottól függően indukálhatja vagy gátolhatja az ET termelődését (Bassi és Spencer 1983). Vörös fénnyel történő megvilágítás után a Pfr aktív forma negatívan szabályozza az ET bioszintézisét számos növényi fajban (Finlayson és mtsai., 1998). Az irodalomból ismert, hogy a levelek sötétben történő inkubációja ET felhalmozódást, valamint sötét-indukálta szeneszcenciát okoz (Lim és mtsai., 2007).

$\mathrm{Az}$ endogén PAO transzkriptum szintek szabályozása dohányban és kukorica mezokotilban a fény által szabályozottak, ugyanis a fény fokozza a PAO expresszióját (Cona és mtsai., 2003; Paschalidis és Roubelakis-Angelakis 2005). A kukoricában található két PAO enzimet ( $Z m P A O 1$ és ZmPAO2) kódoló gén promoter szekvenciájának elemzése során kiderítették, hogy expressziójuk a fényregulált promóter elemek megléte következtében fény általi szabályozást is mutathat (Cervelli és mtsai., 2000). Bár az SA, PA-ok és az ET metabolizmusára gyakorolt hatását vizsgálták már (Gharbi és mtsai., 2016), a PA-ok metabolizmusának idő függvényében történő összehasonlítása fényben és sötétben különböző SA koncentrációkkal történő kezelés során ezidáig még nem történt meg. Továbbá az még nem ismert az irodalomban, hogy az SA indukálta PA változások hogyan történnek aktív ET jelátvitel hiányában. 


\section{Célkitűzések}

Munkánk során célul tüztük ki, hogy megvizsgáljuk, milyen különbségek figyelhetők meg az akklimatizációt segítő szubletális $(0,1 \mathrm{mM})$ SA koncentrációval történő kezelés hatása, valamint a magasabb $(1 \mathrm{mM})$ SA-koncentráció sejthalált indukáló folyamatai között vad típusú Ailsa Craig (VT) paradicsom növények leveleiben? Milyen fiziológiai, biokémiai és génexpressziós különbségek figyelhetök meg a két koncentráció között, és ezeket milyen mértékben befolyásolja a 24 óráig tartó sötétkezelés? Továbbá miben különbözik az SAindukált stresszfolyamatban fontos molekulák mennyisége és enzimek aktivitása egy ET receptor mutáns (Never-ripe) paradicsom növény leveleiben 24 óráig tartó szubletális és letális SA koncentrációval történő kezelés hatására. Ezeket a változásokat milyen mértékben befolyásolják a normál fotoperióduson és a sötétben történő kezelések?

Kutatásaink során az alábbi kérdésekre kerestük a választ:

1. Munkacsoportunk által már előzetesen kiválasztott szubletális és letális SA koncentrációk, hogyan hatnak az idö függvényében, fényben és sötétben, VT paradicsom növények leveleinek a membrán integritásáról információt adó ionkieresztésre, valamint a lipidperoxidáció mértékét jelző malondialdehid (MDA) mennyiségére?

2. Hogyan változik a PA-ok metabolizmusában szerepet játszó enzimek génexpressziója és aktivitása, valamint a szabad PA-ok tartalma, fényben és sötétben töténő szubletális és letális SA kezelés hatására a paradicsom növények leveleiben? Hozzájárulhat-e a PA-ok metabolizmusa az akklimatizációhoz vagy a sejthalál indukciójához?

3. Mivel az SA-nak, valamint a PA-ok terminális lebontása során melléktermékként keletkező $\mathrm{H}_{2} \mathrm{O}_{2}$-nak fontos szerepe van az oxidatív stresszel kapcsolatos folyamatokban, ezért megvizsgáljuk, hogyan hatnak a fényben és a sötétben történő SA kezelések a $\mathrm{O}_{2}{ }^{--}, \mathrm{H}_{2} \mathrm{O}_{2}$ és $\mathrm{NO}$ mennyiségére, valamint a különböző antioxidáns enzimek aktivitására és génexpressziójára? Továbbá kapcsolatban van-e a $\mathrm{H}_{2} \mathrm{O}_{2}$ koncentrációjában bekövetkezett változások a PA-ok terminális lebontását végző enzimek és/vagy az antioxidáns enzimek aktivitásával?

4. Munkánk második felében célunk felderíteni, hogy rövidtávú kezelésben alkalmazott alacsony és magas SA koncentrációk, hogyan hatnak egy ET receptor mutáns (Never-ripe), ezáltal aktív ET jelátvitelt nem tartalmazó paradicsom növény leveleinek $\mathrm{H}_{2} \mathrm{O}_{2}$ tartalmára, fényben és sötétben? 
5. Mivel az ET és a PA-ok metabolizmusa közötti kapcsolat vizsgálata az irodalom alapján hiányosnak, ugyanakkor az adatok sok esetben ellentmondásosnak mondhatóak, ezért célunk megvizsgálni hogyan és milyen mértékben befolyásolja az SA, ET és PA tartalmakat, valamint a PA-ok metabolizmusában szerepet játszó enzimek aktivitását és génexpresszióját az ET jelátvitelének hiánya, fényben és sötétben történő szubletális és letális SA kezeléseket követően?

6. Hogyan befolyásolja az ET jelátvitelének hiánya a különböző antioxidáns enzimek aktivitását és génexpresszióját a két általunk választott SA kezelést követően? Milyen mértékben változnak ezek a folyamatok, ha a 24 óráig tartó kezelések normál fotoperióduson vagy sötétben történnek?

7. Hozzájárulhat-e az ET jelátvitel az SA-indukálta védelmi mechanizmusokhoz, a PA-ok metabolizmusán és az oxidatív stressz kivédésében fontos szerepet játszó antioxidáns enzimek aktivációján keresztül? 


\section{Anyagok és módszerek}

\subsection{Növények nevelési paraméterei}

Kísérleteink során Solanum lycopersicum Mill. L. cvar Ailsa Craig vad típusú (VT), valamint Never-ripe $(\mathrm{Nr})$ paradicsom növényeket használtunk fel. A paradicsom Never-ripe $(N R)$ génje a lúdfü ETR1 génjével homológ, ami jelfogó domén nélküli ET receptort kódol. Az $N r$, ET receptor mutáns, az ET-t érzékelni nem tudó paradicsom növény, melynek termése sosem érik meg teljesen. Az Nr mutáns nemcsak a gyümölcsérésben, hanem a vegetatív szövetekben, az ET indukálta hármas válaszban, epinasztiában, valamint a levél- és termésleválásban is érzéketlenséget mutat az ET-vel szemben (Lanahan és mtsai., 1994). A magokat három napig, sötétben csíráztattuk $26^{\circ} \mathrm{C}$-on. Csírázás után a növények kéthetes korukig perlitben nevelkedtek, majd hidropónikus körülmények között, tápoldatban fejlödtek nyolchetes korukig. A tápoldat a következő makro- és mikorelemeket tartalmazta: $2 \mathrm{mM} \mathrm{Ca}\left(\mathrm{NO}_{3}\right)_{2}, 1 \mathrm{mM} \mathrm{MgSO}$, 0,5 mM KCl, 0,5 mM KH $2 \mathrm{PO}_{4}, 0,5 \mathrm{mM} \mathrm{Na}_{2} \mathrm{HPO}_{4}, 10^{-6} \mathrm{M} \mathrm{MnSO}_{4}, 5 \cdot 10^{-7} \mathrm{M} \mathrm{ZnSO}_{4}, 10^{-7} \mathrm{M}$ $\mathrm{CuSO}_{4}, 10^{-7} \mathrm{M}\left(\mathrm{NH}_{4}\right)_{6} \mathrm{Mo}_{7} \mathrm{O}_{24}, 10^{-5} \mathrm{M} \mathrm{H}_{3} \mathrm{BO}_{4}, 2 \cdot 10^{-5} \mathrm{M}$ Fe-EDTA. A tápoldat pH-ja 5,8 volt. A tápoldatot hetente kétszer cseréltük. A növények a következő nevelési paraméterek mellett fejlődtek: 12 órás nappali és 12 órás éjszakai periódus, $200 \mu \mathrm{mol} \mathrm{m} \mathrm{m}^{-2} \mathrm{~s}^{-1}$ fényintenzitás (F36W/GRO fénycsövek, Osram Sylvania, Danvers, MA, USA) 24/22 ${ }^{\circ} \mathrm{C}$ nappali/éjszakai hőmérséklet és 55-60\%-os relatív páratartalom (Takács és mtsai., 2017).

\subsection{Alkalmazott kezelések}

A SA kezelést a növények 8 hetes korukban 24 óráig a tápoldattal kapták két általunk előzetesen alkalmazott koncentrációban, ahol a $0,1 \mathrm{mM}$ SA szubletálisnak, míg az $1 \mathrm{mM} \mathrm{SA}$ letálisnak bizonyult (Poór és mtsai., 2011). A növények felének fényen történő kezelése a már elözetesen leírt nevelési paraméterek mellett történt, másik fele pedig sötétbe került ahol a páratartalom és a hőmérséklet megegyezett a fényen kezelt körülményekkel. A mintavétel a kezelést követő 1, 3, 6, 12, 24 órában történt a VT Ailsa Craig fajták esetében, míg az $N r$ és VT genotípusok összehasonlításakkor a kezelést követő 24. órában. Méréseinket a csúcstól számított második, harmadik és negyedik levélemeleten lévő, de már teljesen kifejlett levelekből végeztük. A kísérleteket reggel 9 és másnap reggel 9 óra között végeztük és legalább 3 alkalommal ismételtük. 


\subsection{Alkalmazott módszerek}

\subsubsection{Szalicilsav extrakció és mennyiségi analízise}

A SA nagy nyomású folyadékkromatográfiás (High Pressure Liquid Chromatography, HPLC) analízisét Pál és mtsai. (2005) módszere szerint végeztük. 500 mg növényi mintát folyékony nitrogénben, kvarchomok hozzáadásával dörzsmozsárban eldörzsöltünk. A mintákat centrifugacsövekbe öntöttük és $2 \mathrm{ml} 70 \%$-os metanolt adtunk hozzá, mely 250 ng ortoanizinsavat ( $o$-ANI: belső standardként használva) és $25 \mu \mathrm{g}$ para-hidroxi-benzoesavat ( $p$-HBA: extrakciós karrierként használva) tartalmazott. Az extraktumot 10000 g-vel 20 percig centrifugáltuk. A felülúszót félretettük, $2 \mathrm{ml} \mathrm{90 \% -os} \mathrm{metanollal} \mathrm{a} \mathrm{csapadékot} \mathrm{újra} \mathrm{extraháltuk,}$ majd 10000 g-vel 20 percig centrifugáltuk. Az így képződött felülúszót az előzőekben félretetthez öntöttük. Ezzel az eljárással a növényben lévő szabad vegyületeket, illetve a kötöttek közül a metanolban oldódókat lehet kinyerni. Az összegyűjtött felúszókat vákuumbepárlóban vizes fázisig bepároltunk, majd $1 \mathrm{ml}$ 5\%-os (w/v) TCA-t mértünk hozzájuk. Vortexelést követően 13000 g-vel 10 percig centrifugáltuk. A felülúszókat kétszer 2,5 ml ciklohexán: etilacetát $=1: 1(\mathrm{v} / \mathrm{v})$ elegyével ráztuk ki. A felső szerves fázis a szabad fenolos vegyületeket, míg az alsó vizes fázis a metanolban oldódó kötött fenolos vegyületeket tartalmazta. A kötött fenolos vegyületek savas hidrolízise a következőképpen történt: az alsó vizes fázishoz $250 \mu \mathrm{l} 0,1 \mathrm{mg} / \mathrm{ml} p$-HBA-t, $5 \mu \mathrm{l}$ 0,05 mg/ml $o$-ANI-t és 1,3 ml 8N HCl-t adtunk és $80^{\circ} \mathrm{C}$-on 60 percig inkubáltuk. Majd a fent leírt módon kétszer particionáltuk. A HPLC analízis előtt a képződött mintákat vákuumbepárlóban bepároltuk, majd az „A” szolvens $900 \mu$ l-ében visszaoldottuk. A folyadékkromatográfiás méréshez Waters típusú HPLC-t (WATERS, Milford, MA, USA), valamint analitikai oszlopot (Supelcosil ABZ Plus, $5 \mu ; 150 x 4,6 \mathrm{~mm}$ ) használtunk. A mérés során A [25 mM Na-acetát (pH 2,6), 15\% ACN] és B (100\% ACN) szolvenseket használtunk. Detektáláshoz a diódasoros UV/VIS detektorral 230 és 300 nm között teljes spektrumot vettünk fel, melynek egyik célja az, hogy minden vegyületet a maximális abszorbanciánál tudjunk kiértékelni, másrészt a jellemző UV spektrum alapján is lehet azonosítani a csúcsot a retenciós idő mellett (benzoesav, orto-hidroxi-fahéjsav, SA és transz-fahéjsav). A vizsgált vegyületek közül az orto-hidroxi-fahéjsav és az SA fluoreszkál is. Detektálásuk 317 nm gerjesztési és 436 nm kisugárzási (o-HCA), illetve 305 nm gerjesztési és 407 nm kisugárzási hullámhosszon (SA) történt.

\subsubsection{Az életképesség meghatározása}

Az életképességet az elektrolit-kieresztés (EL) alapján határoztuk meg (Poór és mtsai., 2013). $1 \mathrm{~cm}$ átmérőjü, kezelésenként három darab levélkorongot tettünk $25 \mathrm{ml}$ ioncserélt desztillált 
vízbe 2 órára, $25^{\circ} \mathrm{C}$-on, sötétbe. Az inkubáció után meghatároztuk az oldat vezetőképességét (C1) konduktivitásmérővel (OK-102/1 Radelkis, Budapest, Magyarország). A mintákat ezután 40 percig $95^{\circ} \mathrm{C}$-on forraltuk, majd lehütés után ismét meghatároztuk az oldat konduktivitását (C2). A relatív elektrolit kieresztést a következő képlettel számoltuk: Rel. ionkieresztés (EL)= $(\mathrm{C} 1 / \mathrm{C} 2) \mathrm{X} 100$.

\subsubsection{Malondialdehid-tartalom meghatározása}

Az MDA a lipidek peroxidációjának terméke, melynek mennyiségét tiobarbitursavval való reakciója alapján lehet meghatározni. Az MDA tartalom meghatározásához 100 mg levélmintát homogenizáltunk $1 \mathrm{ml} \quad 0,1 \%$ triklórecetsavval (TCA); a további lipidperoxidáció megakadályozására $100 \mu \mathrm{l} \%$ butilált hidroxitoluolt (BHT) adtunk az extraktumhoz. A mintákat 10000 g-n, 20 percig, $4^{\circ} \mathrm{C}$-on centrifugáltuk utána a felülúszó 0,25 ml-éhez $1 \mathrm{ml}$ 0,5\% tiobarbitursavat adtunk, amelyet 20\% TCA-ban oldottunk fel. A reakcióelegyet 30 percig inkubáltuk $96^{\circ} \mathrm{C}$-os vízfürdőben. Az abszorbanciát 532 nm-nél mértük, amit a 600 nm-nél mért nem-specifikus értékkel korrigáltunk. Az MDA koncentrációt $155 \mathrm{mM}^{-1} \mathrm{~cm}^{-1}$ extinkciós koefficienssel számoltuk ki (Horváth és mtsai., 2015).

\subsubsection{Szabad poliaminok meghatározása}

A PA-okat Szepesi és mtsai. (2009) által leírtak szerint határoztuk meg. A növények leveleit $5 \%$-os perklórsavban homogenizáltuk $4^{\circ} \mathrm{C}$-on. Centrifugálás után $\left(12000 \mathrm{~g}, 20\right.$ perc, $\left.4^{\circ} \mathrm{C}\right)$, a felülúszót $2 \mathrm{ml} 2 \mathrm{M} \mathrm{NaOH}$-dal közömbösítettük. A PA-okat benzoil-kloriddal származékká alakítottuk, majd a benzoil-PA-okat $3 \mathrm{ml}$ dietil-éterrel extraháltuk. A szerves fázist szárazra bepároltuk. A benzoil-PA-okat HPLC-n (JASCO HPLC System, Japán) reverz fázisú kolonnán (Apex octadecyl $5 \mu ; 250 x 4,6 \mathrm{~mm}$ ), acetonitril:víz 45:55 (v:v) elegyével választottuk el, és UV detektor segítségével $254 \mathrm{~nm}$-en azonosítottuk.

\subsubsection{RNS izolálás-, DNáz kezelés-, cDNS írás-, qRT-PCR}

A növényekből származó összes RNS kinyeréséhez körülbelül $100 \mathrm{mg}$ mintát folyékony nitrogénben, dörzscsészében homogenizáltunk, majd $1 \mathrm{ml}$ TRI reagenst (1,822 M guanidium izotiocianát, 11,36 mM nátrium-citrát, $200 \mathrm{mM}$ kálium-acetát $\mathrm{pH}$ 4,0, 0,7341 mM $\mathrm{N}$-laurilszarkozin, $45,45 \%$ fenol) adtunk hozzá. A mintákat $65^{\circ} \mathrm{C}$-on 3 percig inkubáltuk, majd $200 \mu \mathrm{l}$ kloroformot adtunk hozzá. Centrifugálás után $\left(10000\right.$ g, 15 perc, $\left.4^{\circ} \mathrm{C}\right)$ a felülúszót $375 \mu$ l kloroform:izoamilalkoholba (24:1) pipettáztuk. Újabb centrifugálást követően (10 000 g, 
15 perc, $4^{\circ} \mathrm{C}$ ) a mintákat $500 \mu$ izopropanolba pipettáztuk és 10 percig szobahőmérsékleten állni hagytuk. Centrifugálás után a pelletet $500 \mu 1$ 70\%-os etanollal tisztítottuk, majd $30 \mu 1$ dietil-pirokarbonátot (DEP) tartalmazó steril desztillált vízben feloldottuk. Az esetleges degradációt agaróz gélelektroforézissel (1\%) ellenőriztük (Gallé 2010).

A mintákat DNáz enzimmel kezeltük. Mintánként $4 \mu \mathrm{l}$ DNáz puffert, $17 \mu \mathrm{l}$ DEP-es vízet és $0,2 \mu \mathrm{l}$ RNáz inhibitort adtunk, valamint $4 \mu$ DNáz enzimet (Fermentas Fermentas UAB, Vilnius, Litvánia). Az elegyet $37^{\circ} \mathrm{C}$-on 30 percig, majd $65^{\circ} \mathrm{C}$-on 10 percig inkubáltuk. A fehérjéket $150 \mu \mathrm{l}$ kloroformmal és $150 \mu \mathrm{l}$ fenollal elimináltuk, majd a mintákat 10000 g-n, 15 percig, $4^{\circ} \mathrm{C}$-on centrifugáltuk. A felülúszót tovább tisztítottuk $200 \mu \mathrm{l}$ kloroformmal, centrifugáltuk (12000 g, 15 perc, $4^{\circ} \mathrm{C}$ ), majd $550 \mu \mathrm{l}$ hideg 96\%-os etanol és $20 \mu \mathrm{l} 3 \mathrm{M}$-os Na-acetát elegyében egy éjszakán át inkubáltuk. Centrifugálás után $\left(12000\right.$ g, 15 perc, $\left.4^{\circ} \mathrm{C}\right)$ $500 \mu \mathrm{l} 70 \%$-os hideg etanollal mostuk, majd a csapadékot $30 \mu \mathrm{l}$ DEP-es vízben feloldottuk. Az esetleges degradációt agaróz gélelektroforézissel (1\%) ellenőriztük (Gallé 2010).

A tisztított RNS-t 200 Unit reverz transzkriptáz (RT) enzim (Fermentas Fermentas UAB, Vilnius, Litvánia) segítségével cDNS-sé írtuk át, $4 \mu$ reverz transzkriptáz reakció puffert, $0,5 \mu \mathrm{l}$ random hexamert, $1 \mu \mathrm{l} 25 \mathrm{mM}$-os dNTP keveréket, 0,5 $\mu 1$ RNáz inhibitort és $13 \mu \mathrm{l}$ DEP-es vizet tartalmazó reakcióelegyben. A reakció $37^{\circ} \mathrm{C}$-on 1 órán át tartott.

A vizsgálni kívánt gének expresszióját kvantitatív valós-idejü PCR segítségével detektáltuk. Az NCBI (http://www.ncbi.nlm.nih.gov/) és a Sol Genomics (http://solgenomics.net/) adatbázisból beazonosított szekvenciákra a Primer 3 szoftver (Rozen és mtsai. 2000) segítségével primereket terveztünk (1. melléklet). A tervezett primer szekvenciák génspecifitását az NCBI BLAST segítségével ellenőriztük vissza (http://blast.ncbi.nlm.nih.gov/Blast.cgi). A $19 \mu 1$ cDNS-t $361 \mu l$ nukleázmentes vízzel kihígítottunk, majd ebböl 1,6 $\mu$ l hígított cDNS-t összekevertünk 0,4 $\mu$ l primerpárral, $5 \mu 1$ SYBRGreen mixxel (Fermentas Fermentas UAB, Vilnius, Litvánia) és $3 \mu l$ steril vízzel. A kvantitatív PCR-t (qRT-PCR) PikoReal-Time PCR készülékkel (Thermo Scientific) végeztük. A reakció során 7 perces $95^{\circ} \mathrm{C}$-on történő hevítést, 40 ciklusból álló sorozat követett (15 másodpercig $95^{\circ} \mathrm{C}, 1$ percig $60^{\circ} \mathrm{C}$ ). A PCR lefutása után a termékek specifikusságát az olvadási görbék nyomonkövetésével ellenöriztük $\left(55^{\circ} \mathrm{C}\right.$-tól $\left.90^{\circ} \mathrm{C}-\mathrm{ig}, 0,2^{\circ} \mathrm{C} / \mathrm{ms}\right)$. Az adatokat a PikoReal szoftver 2.2 (Thermo Scientific) segítségével értékeltuik ki. Az adatok analízisekor a $2^{-\Delta \Delta \mathrm{Ct}}$ módszert alkalmaztuk (Livak és Schmittgen 2001). Referencia génként a paradicsom elongációs faktor 1 alfa (SlEF1) (Lovdal és Lillo 2009), valamint a 18S rRNS (Leclercq és mtsai., 2002) génjét választottuk (1. melléklet). Referencia gének mindvégig konstans expressziós szintet mutatattak a levelekben. A kapott eredményeket a kezdeti kontroll értékeire 
normalizáltuk. Egyes esetekben a kezeléseket követő expressziós gátlás jobb szemléltetése céljából logaritmikus ábrázolást választottunk.

\subsubsection{A poliaminok lebontásában szerepet játszó enzimek aktivitásának meghatározása}

A DAO (EC 1.4.3.6) és a PAO (EC 1.5.3.11) enzimek aktivitásait spektrofotometriásan határoztuk meg (Quinet és mtsai., 2010). A módszer a $\Delta^{-1}$-pirrolin kolorimetriás meghatározásán alapszik. A növényi mintákat folyékony nitrogénben porítottuk, majd extrakciós puffert mértünk rá. Az extrakciós puffer összetétele a következő volt: $1 \mathrm{M}$ Tris $\mathrm{pH}=8.0,50 \%$ glicerol, 20\% Triton-X 100, 100 mM fenil-metil-szulfonil-fluorid (PMSF), $1 \mathrm{mM}$ leupeptin. A mintákat 20 percig jégen inkubáltuk, majd 12000 g-n 10 percig $4^{\circ} \mathrm{C}$-on centrifugáltuk. A reakcióelegy enzimkivonatot, $100 \mathrm{mM}$ kálium-foszfát puffert (pH 6,6), 20 mM Put-ot a DAO enzim aktivitás meghatározásához vagy 20 mM Spd-t a PAO enzim aktivitás meghatározásához, 2-aminobenzaldehidet $(10 \mathrm{mg} / \mathrm{ml}$ törzsoldatból), valamint 50 U kataláz enzimet tartalmazott $1 \mathrm{ml}$ össztérfogatban. A mintákat ezután $37^{\circ} \mathrm{C}$-on 1,5 óráig inkubáltuk. Inkubáció után 20\%-os TCA-t adtunk a mintákhoz, majd 12000 g-n 10 percig $4^{\circ} \mathrm{C}$-on centrifugáltuk. A $\Delta^{-1}$-pirrolin termék keletkezését $430 \mathrm{~nm}$-en az abszorbancia leolvasásával detektáltuk.

\subsubsection{A szuperoxid gyökanion kvalitatív meghatározása}

A $\mathrm{O}_{2}{ }^{-}$detektálására a nitrotetrazólium-kék (NBT) festéket használtuk, ami kék színt adva jelzi a $\mathrm{O}_{2}{ }^{-}$jelenlétét a szövetekben (Wohlgemuth és mtsai., 2002). A mintákat $3 \mathrm{mg} / \mathrm{ml}$ koncentrációjú festékoldatban áztattuk 1 órán keresztül. Ezután leszívtuk az NBT festékoldatot és $25 \mathrm{ml} \mathrm{96 \% -os} \mathrm{etanolt} \mathrm{pipettáztunk} \mathrm{a} \mathrm{helyére,} \mathrm{majd} \mathrm{a} \mathrm{mintákat} 15$ percen keresztül $90^{\circ} \mathrm{C}$-on főztük. A fözést követően az etanolt eltávolítottuk és a leveleket 50\%-os glicerines oldatba helyeztük, amiket ezután lefényképeztünk (Sony Cyber-shot DSC-H9) digitális fényképezőgép segítségével (Sony Co., Tokyo, Japán).

\subsubsection{Hidrogén-peroxid kvantitatív és kvalitatív meghatározása}

A $\mathrm{H}_{2} \mathrm{O}_{2}$ tartalom meghatározásánál Horváth és mtsai. (2015) módszerét használtuk fel. 100 mg friss növényi mintát $0,5 \mathrm{ml}$ hideg $0,1 \%$-os TCA-val eldörzsöltünk, majd lecentrifugáltuk (12 $000 \mathrm{~g}, 20$ perc, $4^{\circ} \mathrm{C}$ ). 0,25 ml felülúszóhoz hozzáadtunk 0,25 ml $50 \mathrm{mM} \mathrm{K}$-foszfátpuffert (pH 7) és 0,5 ml 1 M-os KI oldatot, majd összekevertük és 10 perc után, 390 nm-en 
fotometráltuk (KONTRON kétsugaras spektrofotométer, Milano, Olaszország). A $\mathrm{H}_{2} \mathrm{O}_{2}$ mennyiségeket nmol $\mathrm{g}^{-1}$ friss tömegre (FT) vonatkoztatva adtuk meg. A kalibrációt $\mathrm{H}_{2} \mathrm{O}_{2}$ hígítási sorozatával készítettük.

A $\mathrm{H}_{2} \mathrm{O}_{2}$ in situ detektálására a levelekben 3'3-diamino-benzidin (DAB) festéket használtunk, ami sötétbarnás színt adva jelzi a $\mathrm{H}_{2} \mathrm{O}_{2}$ jelenlétét a szövetekben (ThordalChristensen és mtsai., 1997). A mintákat $25 \mathrm{ml} 2 \mathrm{mg} / \mathrm{ml}$ koncentrációjú festékoldatban áztattuk 2 órán keresztül. A DAB-festékoldat eltávolítása után a mintákat 15 percen keresztül $90{ }^{\circ} \mathrm{C}$-on főztük 96\%-os etanolban. A fözést követően az etanolt eltávolítottuk és a leveleket 50\%-os glicerines oldatba helyeztük, amiket ezután lefényképeztünk (Sony Cyber-shot DSC-H9) digitális fényképezőgép segítségével (Sony Co., Tokyo, Japán).

\subsubsection{A levelek NO termelődésének meghatározása}

A különböző koncentrációjú kezelések hatására bekövetkező NO termelődést a 4-amino-5metilamino-2',7'-difluorofluoreszcein-diacetát (DAF-FM-DA) fluoreszcens festékkel detektáltuk (Poór és mtsai., 2015). A festék zöld fluoreszcenciát mutató formája az NO jelenlétét jelzi a mintákban. A festés 3,5 $\mathrm{ml} 10 \mu \mathrm{M}$ koncentrációjú festékkel, 30 percig történt szobahőmérsékleten. Ezután a mintákat 4-szer MES/KCl pufferrel $(10 \mathrm{mM} / 50 \mathrm{mM}$, pH 6,15) mostuk, majd Zeiss Axiovert 200M típusú mikroszkóp alatt (Carl Zeiss Inc., Jena, Németország), a 10-es filterszett segítségével vizsgáltuk (excitáció 450-495nm, emisszió 515$565 \mathrm{~nm})$. Az expozíciós idő 2,42 s volt. A felvételek elkészítésénél ötszörös objektívet alkalmaztunk. A mintákról nagy felbontású digitális kamera segítségével fotókat készítettünk (Axicam HR), majd a képeket az Axiovision 4.8 szoftver (Carl Zeiss Inc., München, Németország) segítségével dolgoztuk fel. Az NO-t jelző festék zöld fluoreszcenciájának alapján megmértük a levelek pixelintenzitását, $600 \mu \mathrm{m}$ átmérőjü körben ami az NO mennyiségével arányos. Az eredményeket kontroll százalékban fejeztük ki.

\subsubsection{Az etilén termelődés meghatározása}

A növényi szövetek 1 g-ját gázgyüjtő üvegekbe helyeztük, melyeket szilikongumival ellátott kupakkal zártunk le. A mérés megkezdése előtt a mintákat 1 órán keresztül inkubáltuk sötétben. Az ET termelődést gázkromatográf segítségével (Hewlett-Packard 5890 Series II, Avondale PA, USA), lángionizációs detektorral, alumínium-oxiddal töltött oszlopon határoztuk meg. A hélium vivőgáz áramlási sebessége $35 \mathrm{~cm}^{3}$ perc ${ }^{-1}$, a hidrogéné $30 \mathrm{~cm}^{3}$ perc ${ }^{-1}$, a levegóé $350 \mathrm{~cm}^{3}$ perc ${ }^{-1}$ volt. $\mathrm{Az}$ injektor hőmérséklete $120^{\circ} \mathrm{C}$, a kolonnáé $100^{\circ} \mathrm{C}$, a lángionizációs detektoré 
$160^{\circ} \mathrm{C}$ volt. Az ET mennyiségét standard állapotú, ismert koncentrációjú ET-vel készített kalibráció alapján nmol g ${ }^{-1} \mathrm{FT}_{\text {óra }}{ }^{-1}$ értékben adtuk meg (Tari és mtsai. 2006).

\subsubsection{Antioxidáns enzimek és a NADPH-oxidáz aktivitásának vizsgálata}

Az antioxidáns enzimek aktivitásának meghatározásához minden esetben $200 \mathrm{mg}$ levelet homogenizáltunk jégen $1 \mathrm{ml} 100 \mathrm{mM}$ kálium-foszfát pufferben (pH 7,0), amely $1 \mathrm{mM}$ PMSF és $1 \%$ polivinil-polipirrolidont (PVPP) tartalmazott. Az APX enzim aktivitásának meghatározásához az extrakciós puffer $1 \mathrm{mM}$ ASC-t is tartalmazott. A NADPH-oxidáz és a különböző antioxidáns izoenzimek natív poliakrilamid gélelektroforézissel (PAGE) történő elválasztásához $500 \mathrm{mg}$ levelet folyékony nitrogénben, dörzscsészében homogenizáltunk, majd a NADPH-oxidáz izoenzimek elválasztásához $1 \mathrm{ml} 50 \mathrm{mM}$ Na-foszfát puffert (pH 6,8) és 0,5\% Triton X-100 oldatot adtunk hozzá. A SOD, APX, POD meghatározásához $1 \mathrm{ml}$ extrakciós puffert (50 mM kálium-foszfát puffer pH 7,0 és $1 \mathrm{mM} \mathrm{PMSF}$ ) használtunk. Az APX enzim aktivitásának meghatározásához az extrakciós puffer $2 \mathrm{mM}$ ASC-ot is tartalmazott. A mintákat 20 percig $12000 \mathrm{~g}-\mathrm{n} 4^{\circ} \mathrm{C}$-on centrifugáltuk és a továbbiakban a felülúszót használtuk.

Az elektroforézist a NADPH-oxidáz, SOD, APX meghatározásához 10\%-os, míg a POD meghatározásához 6\%-os, 2 mm vastagságú és $120 \mathrm{~mm}$ hosszúságú lapgélen, natív körülmények között, $4^{\circ} \mathrm{C}$-on végeztük függőleges állású omniPAGE elektroforézis rendszerrel (Cleaver Scientific Ltd., Rugby, Warwickshire, UK). Szeparáló gélünk 5 ml (30\% akrilamidból és $0,8 \%$ biszakrilamidból álló) akrilamid oldatot, 3,75 ml 1,5 M-os (pH 8,8) TRIS-HCl oldatot, 6,1 ml desztillált vizet, $150 \mu 1$ 10\%-os ammónium-peroxi-diszulfátot (APS) és $15 \mu$ tetrametiletilén-diamint (TEMED) tartalmazott. A gyüjtő gél 1,27 ml akrilamid oldatból, 0,937 ml 1 M-os (pH 6,8) TRIS-HCl oldatból, $5,17 \mathrm{ml}$ desztillált vízből, $75 \mu \mathrm{l}$ APS-ből és 7,5 $\mu 1$ TEMED-ből állt. A gyüjtő gél a NADPH-oxidáz, SOD, APX esetében 4\%-os, míg a POD esetében 3\%-os koncentrációjú volt.

A gélre mintánként $30 \mu \mathrm{g}$ fehérjét tartalmazó enzimkivonatot vittünk fel. A futtató puffer 14,4 g glicint és 3,0 g TRIS-t tartalmazott ( $\mathrm{pH} \mathrm{8,3)} \mathrm{literenként.} \mathrm{A} \mathrm{futtatást} 3$ órán keresztül 20 mA áramerősséggel végeztük.

\subsubsection{NADPH-oxidáz izoenzimek meghatározása}

A futtatást követően a gélen található NADPH-oxidáz izoenzimeket Carter és mtsai. (2007) festési módszerével tettük láthatóvá. $50 \mathrm{ml} 50 \mathrm{mM}(\mathrm{pH}$ 7,4) Tris- $\mathrm{HCl}$ pufferben feloldottunk

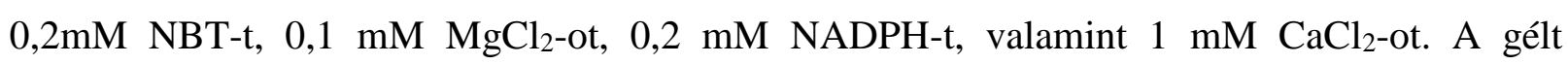
20 percig ráztuk sötétben az izoenzimek megjelenéséig. 


\subsubsection{Szuperoxid-dizmutáz enzim}

A SOD (EC 1.15.1.1) aktivitást az NBT riboflavin jelenlétében történő fotokémiai redukciójának gátlása alapján határoztuk meg (Tari és mtsai., 2015). A reakcióelegy enzimkivonatot, $50 \mathrm{mM}$-os NBT és $0,2 \mathrm{mM}$-os riboflavint tartalmazott. A 15 perc után keletkezett formazán extinkcióját 560 nm-en mértük. Egy enzimegység (U) azt az enzimmennyiséget jelenti, amely az NBT redukciójának 50\%-os gátlását okozza fény jelenlétében. Az enzim aktivitását $\mathrm{U} \mathrm{mg}^{-1}$ fehérje egységben adtuk meg.

A futtatást követően a gélen található SOD izoenzimeket Feigl és mtsai. (2014) negatív festési módszerével tettük láthatóvá. $50 \mathrm{ml} 50 \mathrm{mM}(\mathrm{pH}$ 7,8) Na-foszfát pufferben feloldottunk 2,45 mM NBT-t és 20 percig ráztuk a gélt sötétben. Ezt követően $50 \mathrm{ml} 50 \mathrm{mM}(\mathrm{pH} 7,8)$ Na-foszfát pufferben feloldottunk $28 \mu \mathrm{M}$ riboflavint és $28 \mathrm{mM}$ TEMED-et, majd újabb 20 percig ráztuk a gélt sötétben. Átmosást követőn az elöhívást a gél 15 percig történő megvilágításával végeztük. A megvilágítás hatására a gél lila lett, kivéve a SOD-ot tartalmazó részeket.

\subsubsection{Kataláz enzim}

A KAT (EC 1.11.1.6) enzim meghatározása Tari és mtsai. (2015) alapján történt. A reakcióelegy $50 \mathrm{mM}$-os kálium-foszfát puffert $(\mathrm{pH} 7,0), 1 \%$-os $\mathrm{H}_{2} \mathrm{O}_{2}$-ot és enzimkivonatot tartalmazott. A KAT aktivitását a $\mathrm{H}_{2} \mathrm{O}_{2}$ lebontásának nyomon követésével határoztuk meg $240 \mathrm{~nm}$ hullámhosszon spektrofotométerrel, az 1. és 2. perc között mért extinkcióváltozás alapján. Egy enzimegység (U) az az enzimmennyiség, mely $1 \mu \mathrm{mol} \mathrm{H}_{2} \mathrm{O}_{2}$ elbontását katalizálja 1 perc alatt. A specifikus aktivitás számítása extinkciós koefficiens $\left(\varepsilon_{240}=39,4 \mathrm{mM}^{-1} \mathrm{~cm}^{-1}\right)$ használatával történt.

\subsubsection{Aszkorbát-peroxidáz enzim}

Az APX (EC 1.11.1.11) enzim meghatározása Tari és mtsai. (2015) protokollja szerint történt. A reakcióelegy 50 mM-os kálium-foszfát puffert (pH 7,0), $5 \mathrm{mM}$ redukált ASC-ot és enzimkivonatot tartalmazott. A reakciót $10 \mathrm{mM}$-os $\mathrm{H}_{2} \mathrm{O}_{2}$ hozzáadásával indítottuk. A mérés kvarcküvettában $290 \mathrm{~nm}$ hullámhosszon történt 1,5 percig. Egy enzimegység (U) az az enzimmennyiség, amely $1 \mu$ mol ASC oxidációját katalizálja egy perc alatt. A specifikus aktivitás számítása extinkciós koefficiens $\left(\varepsilon_{290}=2,8 \mathrm{mM}^{-1} \mathrm{~cm}^{-1}\right)$ használatával történt. 
A futtatást követően a gélen található APX izoenzimeket Kim és mtsai. (2015) negatív festési módszerével tettük láthatóvá. $50 \mathrm{ml} 50 \mathrm{mM}(\mathrm{pH}$ 7,0) kálium-foszfát pufferben feloldottunk $2 \mathrm{mM}$ ASC-ot és 30 percig ráztuk a gélt sötétben (minden 10. percben lecseréltük az oldatot). Ezt követően $50 \mathrm{ml} 50 \mathrm{mM}$ (pH 7,0) kálium-foszfát pufferben feloldottunk $4 \mathrm{mM}$ ASC-ot és hozzáadtunk $2 \mathrm{mM} \mathrm{H}_{2} \mathrm{O}_{2}$-ot, majd újabb 20 percig ráztuk a gélt sötétben. A gélt átmostuk $50 \mathrm{mM-os}(\mathrm{pH}$ 7,8) foszfát pufferben, majd újabb $50 \mathrm{mM-os}(\mathrm{pH} 7,8)$ káliumfoszfát pufferbe helyeztük, ami $28 \mathrm{mM}$ TEMED-et és $2 \mathrm{mM}$ NBT-t tartalmazott és 2-3 percig inkubáltuk. A reakció során a gél lila lett az NBT ASC általi redukciója miatt, kivéve az APX izoenzimeket tartalmazó részeket.

\subsubsection{Gvajakol-peroxidáz enzim}

A POD (EC 1.111.7) enzim meghatározása Horváth és mtsai. (2015) alapján történt. A reakcióelegy $50 \mathrm{mM-os} \mathrm{kálium-foszfát} \mathrm{puffert} \mathrm{(pH} \mathrm{7,0),} \mathrm{1 \% -os} \mathrm{gvajakolt} \mathrm{és} \mathrm{enzimkivonatot}$ tartalmazott. A reakciót 1\%-os $\mathrm{H}_{2} \mathrm{O}_{2}$ oldat hozzáadásával indítottuk. A POD aktivitásának meghatározására $470 \mathrm{~nm}$ hullámhosszon, a gvajakol oxidációja során történő abszorbancia növekedés detektálásával történt. Egy U-nak azt az enzimmennyiséget tekintettük, amely 1 $\mu$ mol tetragvajakol képződését katalizálta 1 perc alatt. A specifikus aktivitás számítása extinkciós koefficiens $\left(\varepsilon_{470}=26,6 \mathrm{mM}^{-1} \mathrm{~cm}^{-1}\right)$ használatával történt.

A futtatást követően a gélen található POD izoenzimeket Limones és mtsai. (2002) festési módszerével tettuik láthatóvá. $50 \mathrm{ml} 100 \mathrm{mM}(\mathrm{pH} \mathrm{6,5)} \mathrm{kálium-foszfát} \mathrm{pufferben}$ inkubáltuk a gélt, majd $50 \mathrm{ml} 100 \mathrm{mM}$ (pH 6,5) kálium-foszfát pufferben feloldottunk 12,5 mM gvajakolt, $1,7 \mathrm{mM}$ benzidint és $12 \mathrm{mM} \mathrm{H}_{2} \mathrm{O}_{2}$-t és a barnás narancssárgás izoenzimeket jelző sávok megjelenéséig ráztuk benne a gélt.

\subsubsection{A fehérjetartalom meghatározása}

A fehérjetartalom meghatározását Bradford (1976) módszere alapján végeztük. Kezelésenként $2 \mu 1$ mintát adtunk $900 \mu 1$ desztillált vízhez és $100 \mu 1$ Bradford festékhez (Biorad, Hercules CA, USA), majd alapos keverést követően, legalább 10 perces inkubációt követően 595 nm-en fotometráltuk őket.

\subsubsection{Statisztikai analízis}

A mikroszkópos felvételek értékelése minden esetben az Axiovision 4.8 program segítségével történt. Az eredmények átlag \pm standard hiba (SE) formátumban kerültek ábrázolásra. A mért 
adatokat SigmaStat 12 program segítségével dolgoztuk fel és értékeltük ki. A kontrolltól való szignifikáns különbségeket a varianciaanalízist követően Duncan-féle teszttel állapítottuk meg, ahol a különböző betűvel jelölt átlagok $P \leq 0,05$ valószínűségi szinten különböznek egymástól szignifikánsan. 


\section{Eredmények}

\subsection{A különböző SA kezelések által indukált oxidatív stressz vizsgálata normál fotoperióduson, valamint sötétben kezelt vad típusú Ailsa Craig paradicsom növények leveleiben}

\subsubsection{Az endogén szabad, kötött és összes SA tartalmak változásai}

Mivel a fény fontos szerepet játszik a növények transzport folyamataiban, ezért kíváncsiak voltunk, hogy az exogén SA kezelések hogyan hatnak az endogén szabad, kötött és összes SA tartalomra fényben és sötétben vad típusú Ailsa Craig (VT) paradicsom növények leveleiben (5. ábra). A jelátvitelt a szabad SA indukálja, míg a kötött formákból a szabad SA felszabadulhat.

Normál fotoperióduson tartott kontroll levelek szabad SA tartalma $0,06 \pm 0.01 \mu \mathrm{g} \mathrm{g}^{-1}$ FT volt, amely nem mutatott szignifikáns változást a sötét kezelés hatására, kivéve a 24. óra végére, ahol kismértékü csökkenés volt tapasztalható (5. ábra A). Ezzel szemben a kötött SA tartalom kontroll körülmények között már alacsonyabb volt a 6 . órától a sötétben, mint a fényben (5. ábra D). Az összes SA tartalom kontroll körülmények között $0.06 \pm 0.20 \mu \mathrm{g} \mathrm{g}^{-1} \mathrm{FT}$ volt, amely megfelel az irodalomban megtalálható adatoknak (5. ábra G). 0,1 mM SA kezelés hatására a szabad és az összes SA mennyisége 80 szorosára emelkedett a normál fotoperióduson tartott paradicsom növények leveleiben (5. ábra B, H), amelynek koncentrációja a kezelést követő 6. órában már elérte a felhalmozódás maximumát. Exogén $0,1 \mathrm{mM} \mathrm{SA}$ kezelés sötétben történő alkalmazása később és kisebb mértékben emelte meg az endogén szabad, kötött és összes SA koncentrációját a normál fotoperióduson kezelt körülményekhez képest (5. ábra B, E, H). A letális, 1 mM SA kezelés hatására a szabad SA tartalom 1200 szorosára növekedett mindkét körülmény esetén, ugyanakkor az SA koncentrációja már a kezelést követő 3. órában elérte a maximumát (5. ábra $\mathrm{C}$ ). A kötött SA mennyisége a letális koncentráció hatására szignifikánsan magasabb volt fényben, mint sötétben, míg az összes SA mennyisége a kezelést követő 12. óránál mutatott szignifikáns különbséget (5. ábra F, I). Érdekesség, hogy a szubletális és letális SA kezelést követően a kezelések 24. órájában már nem tapasztalható szignifikáns különbség az endogén szabad és összes SA mennyisége között, normál fotoperióduson és sötétben sem. 

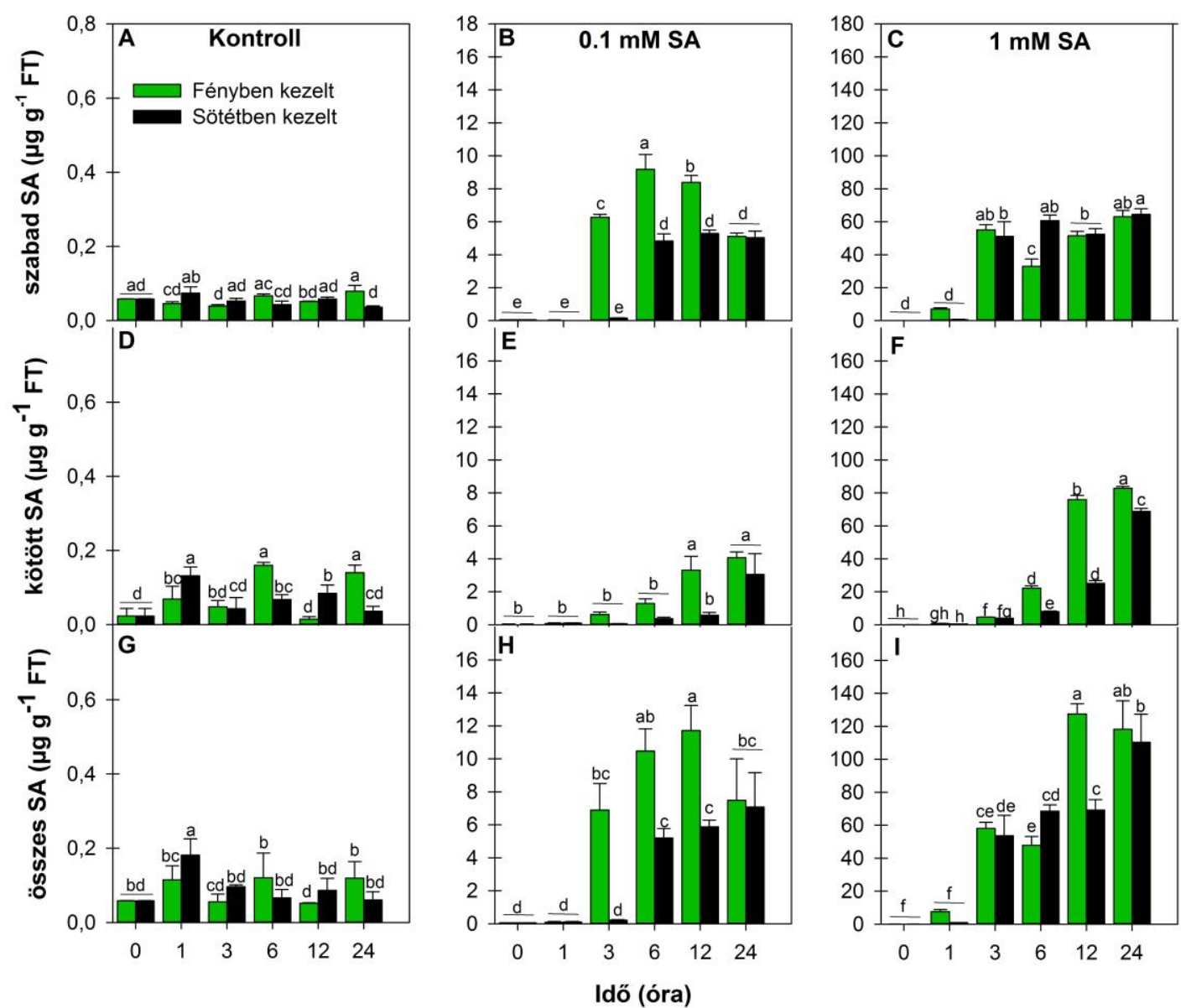

5. ábra: Az endogén szabad (A, B, C), kötött (D, E, F) és összes (G, H, I) szalicilsav (SA) tartalom változása $\left(\mu \mathrm{g} \mathrm{g}^{-1} \mathrm{FT}\right)$ vad típusú VT paradicsom növények leveleiben kontroll körülmények között (A, D, G), valamint 24 óráig tartó $0,1 \mathrm{mM}(\mathrm{B}, \mathrm{E}, \mathrm{H})$ és $1 \mathrm{mM}(\mathrm{C}, \mathrm{F}, \mathrm{I})$ SA kezelést követően fényben ( $\square$ ) és sötétben (ם) (Átlag $\pm \mathrm{SE}, \mathrm{n}=3$ ). A különböző betüvel jelzett oszlopok $P \leq 0,05$ valószínüségi szinteken szignifikánsan különböznek egymástól a Duncan teszt alapján.

\subsubsection{A plazmamembrán integritásának és stabilitásának változása}

További kísérleteink során megvizsgáltuk a 24 óráig tartó $0,1 \mathrm{mM}$ és $1 \mathrm{mM}$ koncentrációjú SA-val történő kezelést követően, hogyan változik az idő függvényében a VT paradicsom növények leveleinek életképessége az EL, valamint a lipidperoxidáció mértékéről információt adó MDA koncentrációja alapján, normál fotoperióduson, valamint sötétben, ugyanis a lipidperoxidáció következtében fellépő membránkárosodás végső soron sejthalálhoz vezethet (Biswas és Mano 2015).

Amennyiben az EL értéke magas, a sejtek PM-je károsodott, mely egy kezdeti jele a sejt halálának. A levelek életképessége az EL alapján az alkalmazott két SA koncentráció esetén szignifikánsan csak az $1 \mathrm{mM}$ SA kezelést követően csökken, míg a 0,1 mM SA kezelés nem okozott szignifikáns változást a kontrollhoz képest a 24 órás kezelés alatt, fényben és sötétben (6. ábra A, B, C). Továbbá megállapítható, hogy az 1 mM SA kezelés erőteljesebb EL-t, ezáltal 
nagyobb mértékű pusztulást a fényben történő kezelés során okozott az VT paradicsom növények leveleiben (6. ábra C).

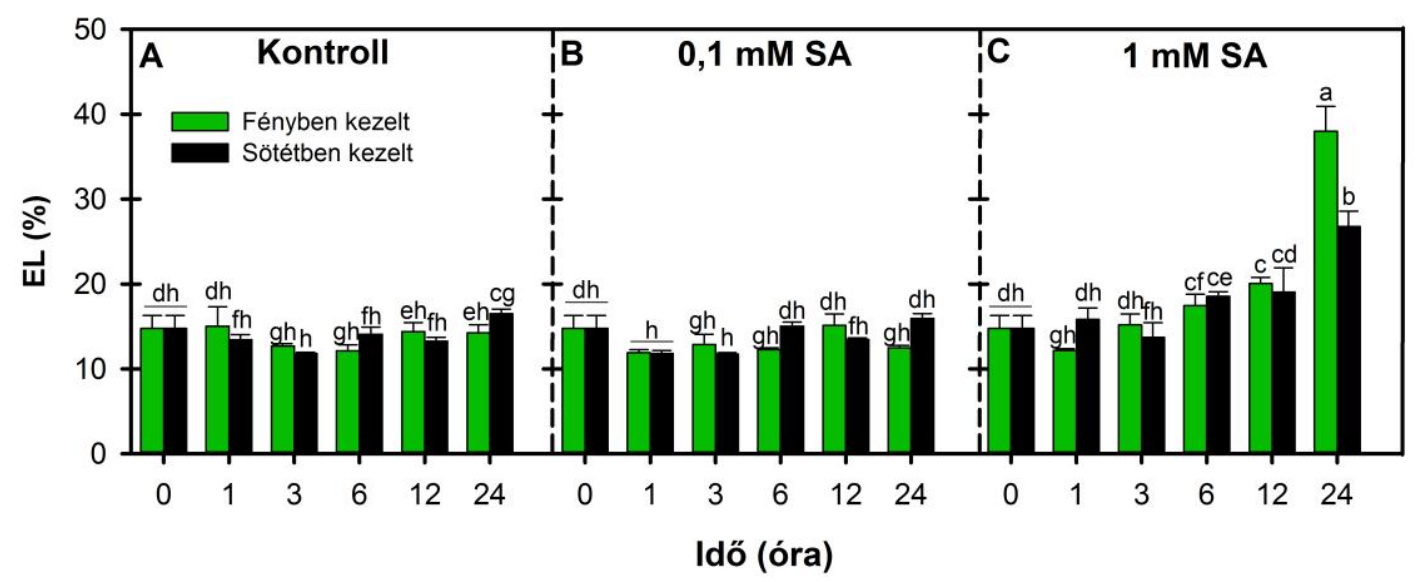

6. ábra: Az EL \%-os változása VT paradicsom növények leveleiben kontroll körülmények között (A), valamint 24 óráig tartó $0,1 \mathrm{mM}$ (B) és $1 \mathrm{mM}(\mathrm{C})$ SA kezelést követően fényben ( $\square$ ) és sötétben ( $\square$ ) (Átlag $\pm \mathrm{SE}, \mathrm{n}=6, P \leq 0,05$ ).

Megvizsgáltuk a paradicsom növények levelében a lipidperoxidáció mértékét jelző, MDA tartalom alakulását is. A $0,1 \mathrm{mM}$ SA-val kezelt növények MDA tartalma fényben és sötétben nem különbözött szignifikánsan a kontrollhoz képest (7. ábra A, B). 1 mM SA kezelést követően a levelek MDA tartalma már a kezelést követő 6. órában szignifikáns emelkedést mutatott a fényben, ami az idő függvényében folyamatosan nőtt. Ez az emelkedés a sötétben kezelt növények levelében is megfigyelhető volt a kezelést követő 6. órában, azonban a fényhez képest szignifikánsan alacsonyabb volt az MDA mennyisége (7. ábra C).

A kapott eredmények alapján megállapíthatjuk, hogy a PM stabilitása és integritása szignifikánsan az 1 mM SA kezelést követően csökkent, melynek mértéke a normál fotoperióduson történő kezelés során nagyobb volt, mint amikor a növényeket meghosszabbított sötét perióduson tartottuk. 


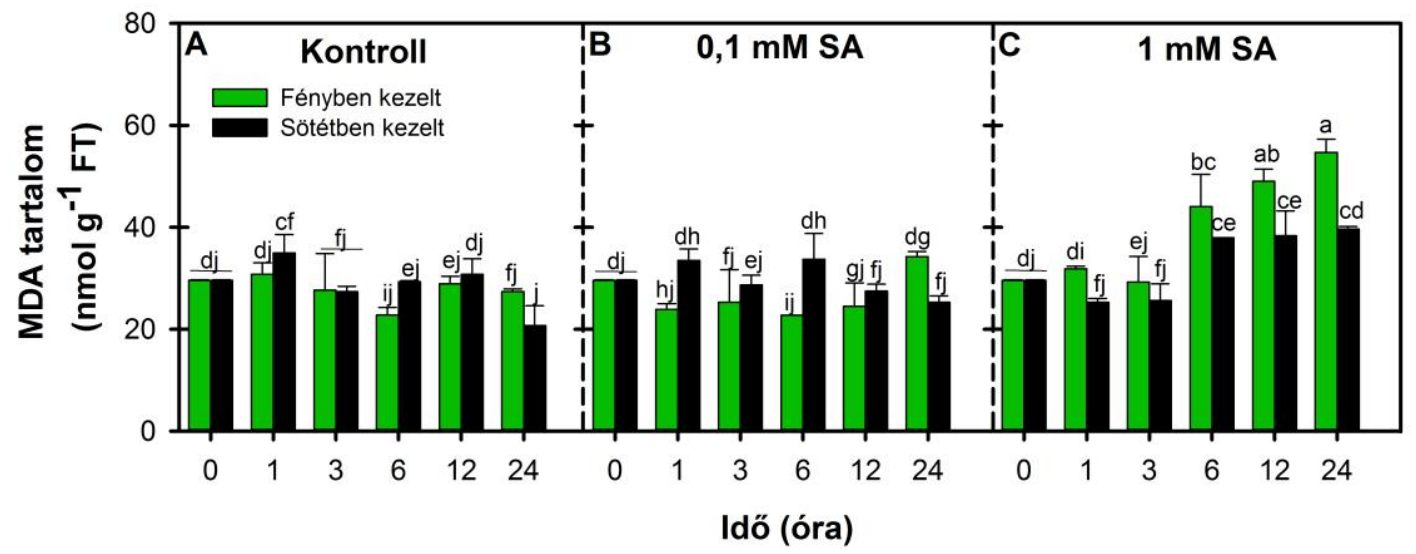

7. ábra: Az MDA tartalom változása VT paradicsom növények leveleiben kontroll körülmények között (A), valamint 24 óráig tartó $0,1 \mathrm{mM}$ (B) és $1 \mathrm{mM}$ (C) SA kezelést követően fényben ( $\square$ ) és sötétben (ם) (Átlag $\pm \mathrm{SE}, \mathrm{n}=3, P \leq 0,05$ ).

\subsubsection{A szabad poliaminok koncentrációjának változásai}

Fiziológiai körülmények között fiatal hajtásban a Put és Spd sejten belüli koncentrációja az Spm mennyiségéhez képest magasabb volt fényben és sötétben egyaránt. A megvilágított kontroll növények szabad PA mennyiségei napi ritmust mutattak, melyek koncentrációi késő délután érték el a maximumukat (8. ábra A, D, G). Ezzel szemben a sötétben tartott növények leveleiben mérhető Put és Spd mennyisége már az első órákban szignifikáns emelkedést mutatott (8. ábra A, D). A 24 óráig tartó szubletális és letális SA kezelések különböző módon hatottak a szabad PA-ok mennyiségére, mind normál fotoperióduson, mind pedig a sötétben történő kezelések során. 0,1 mM SA normál fotoperióduson nem változtatta meg szignifikánsan a Put mennyiségét, míg a sötétben kezelt növényeknél már a kezelést követő első órában szignifikáns emelkedés volt tapasztalható a kontrollhoz képest (8. ábra B). Ezzel szemben az Spd koncentrációja csak kismértékben emelkedett meg a 0,1 mM SA kezelés hatására a kontrollhoz képest, valamint nem mutatott szignifikáns különbséget fényben és sötétben (8. ábra $\mathrm{E})$. Az Spm mennyisége fényben a $0,1 \mathrm{mM}$ SA kezelést követő 6 . órától mutatott szignifikáns emelkedést, míg ha a növényeket sötétben kezeltük az Spm mennyisége ellentétesen, a kezelés első 6 órájában emelkedett meg szignifikánsan (8. ábra H). 1 mM SA kezelés hatására a Put mennyisége szignifikánsan nőtt fényben és sötétben is, mely a kezelést követő 12. órától nagyobb emelkedést mutatott sötétben, mint a normál fotoperióduson (8. ábra C). Az Spd mennyisége a letális SA koncentrációval történő kezelést követő 6. órától mutatott szignifikáns emelkedést a sötétben (8. ábra F). Az 1 mM SA kezelést követően a legnagyobb változást az Spm koncentrációjában tapasztaltuk, továbbá mennyisége a sötétben kezelt növények levelében hamarabb elérte maximumát, mint a fényben kezelt növényeknél (8. ábra I). 
Összefoglalásképpen elmondható, hogy a 24 óráig tartó letális SA koncentráció hatására normál fotoperióduson az Spm, míg sötétben a Put és Spm együttes emelkedése volt döntő jelentőségü, amely a PA-ok fényben és sötétben betöltött eltérő funkcióját feltételezi az SA indukálta reakciókban.

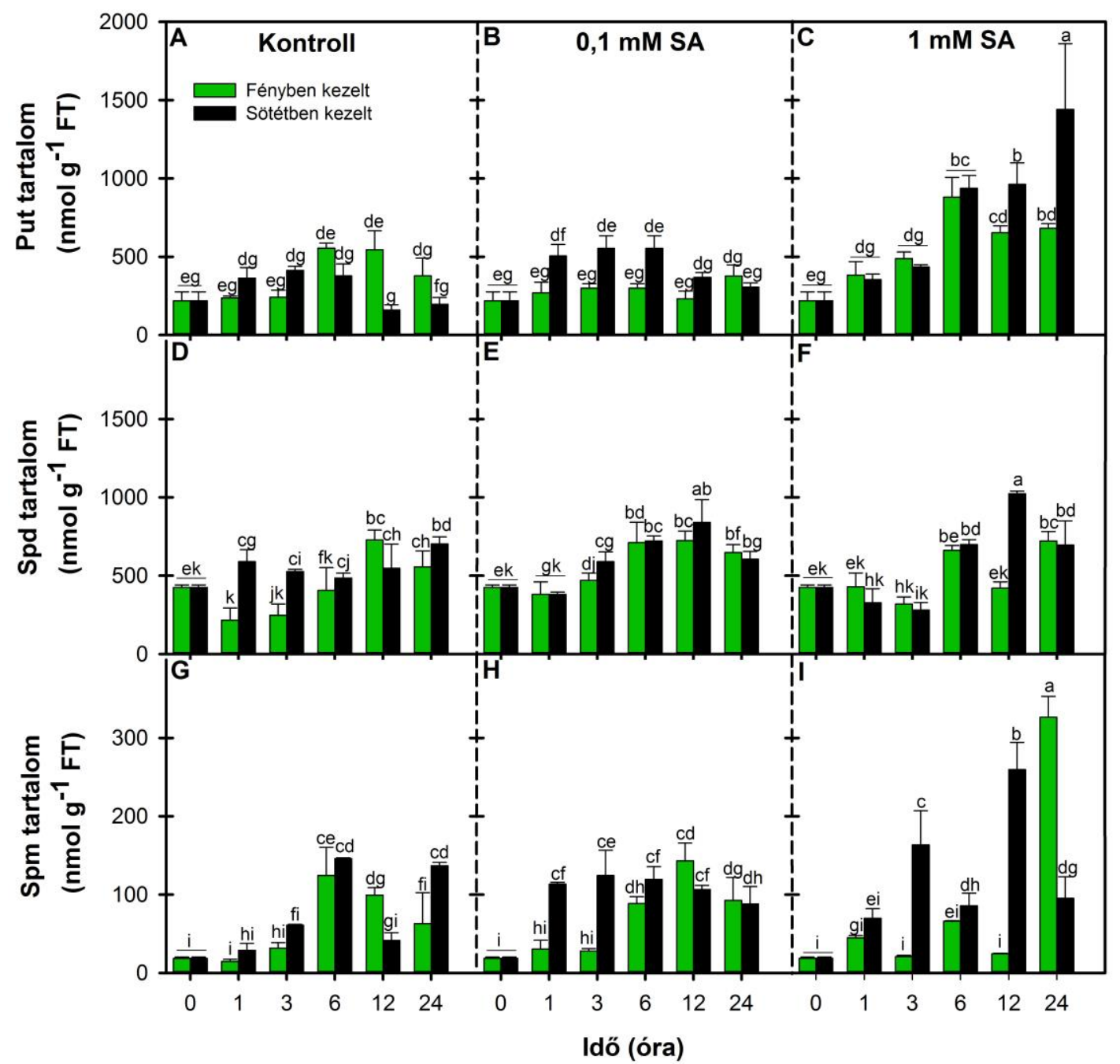

8. ábra: A szabad PA [Put (A, B, C); Spd (D, E, F); Spm (G, H, I)] mennyiségének változása VT paradicsom növények levelében kontroll körülmények között (A, D, G), valamint 24 óráig tartó $0,1 \mathrm{mM}$ $(\mathrm{B}, \mathrm{E}, \mathrm{H})$ és $1 \mathrm{mM}(\mathrm{C}, \mathrm{F}, \mathrm{I}) \mathrm{SA}$ kezelést követően fényben ( $\square$ ) és sötétben (ם) (Átlag $\pm \mathrm{SE}, \mathrm{n}=3$, $P \leq 0,05)$.

\subsubsection{A PA-ok bioszintézisében szerepet játszó enzimeket kódoló gének expressziójának változásai}

A PA-ok bioszintézisében szerepet játszó bioszintetikus gének, úgy mint az $S l A D C, S l O D C$, SISPDS és SISPMS relatív transzkript szintjének változását is megvizsgáltuk qRT-PCR segítségével.

Kontroll körülmények között a Put bioszintézisében szerepet játszó SIADC és SIODC gének expressziós szintjei kismértékben csökkentek a nap folyamán, azonban ez a csökkenés a sötétben tartott növények leveleiben a 24. órában is megmaradt (9. ábra A, D). Kontroll 
körülmények között az SISPDS gén relatív transzkript szintje fényben kismértékü szignifikáns emelkedést mutatott a 12. és 24. órában, míg az SISPMS gén expressziója nem adott szignifikáns különbséget a fényben és a sötétben tartott növények leveleiben sem (9. ábra G, J).

0,1 mM SA kezelés hatására az SIADC gén expressziója növekedést mutatott mindkét körülmény során, azonban sötétben korábban és nagyobb mértékben emelkedett meg a fényben kezelt növények leveleihez képest (9. ábra B). Ezzel szemben a 0,1 mM SA kezelés hatására az SIODC gén expressziója nem mutatott szignifikáns változást egyik környezetben sem (9. ábra E). 0,1 mM SA kezelés indukálta az SISPDS gén expresszóját a kezelést követö 3. órában, azonban indukciója nem mutatott szignifikáns különbséget a fényben és sötétben kezelt növények között (9. ábra H). Az SlSPMS gén expressziója sötében a 0,1 mM SA kezelést követő első és 3. órában indukálódott, míg a fényben kezelt növények esetében nem mutatott szignifikáns különbséget (9. ábra K).

A szubletális koncentrációval ellentétben, a letális SA koncentráció nagyobb mértékben és mindkét, a Put bioszintézisében szerepet játszó $S I A D C$ és $S I O D C$ gének expresszióját indukálta, fényben és sötétben egyaránt. Azonban ez a fényben hamarabb történt, mint a sötétben kezelt növényeknél (9. ábra C, F). Az SISPDS és SISPMS gén expressziója 1 mM SA kezelést követő 6. és 24. órában indukálódott, mely indukció a sötétben kezelt növények leveleiben elmaradt (9. ábra I, L). Továbbá az is megállapítható, hogy az SISPMS gén relatív transzkript szintje koraibb és nagyobb mértékü indukciót mutatott már a kezelést követő 3. órától (9. ábra L). 


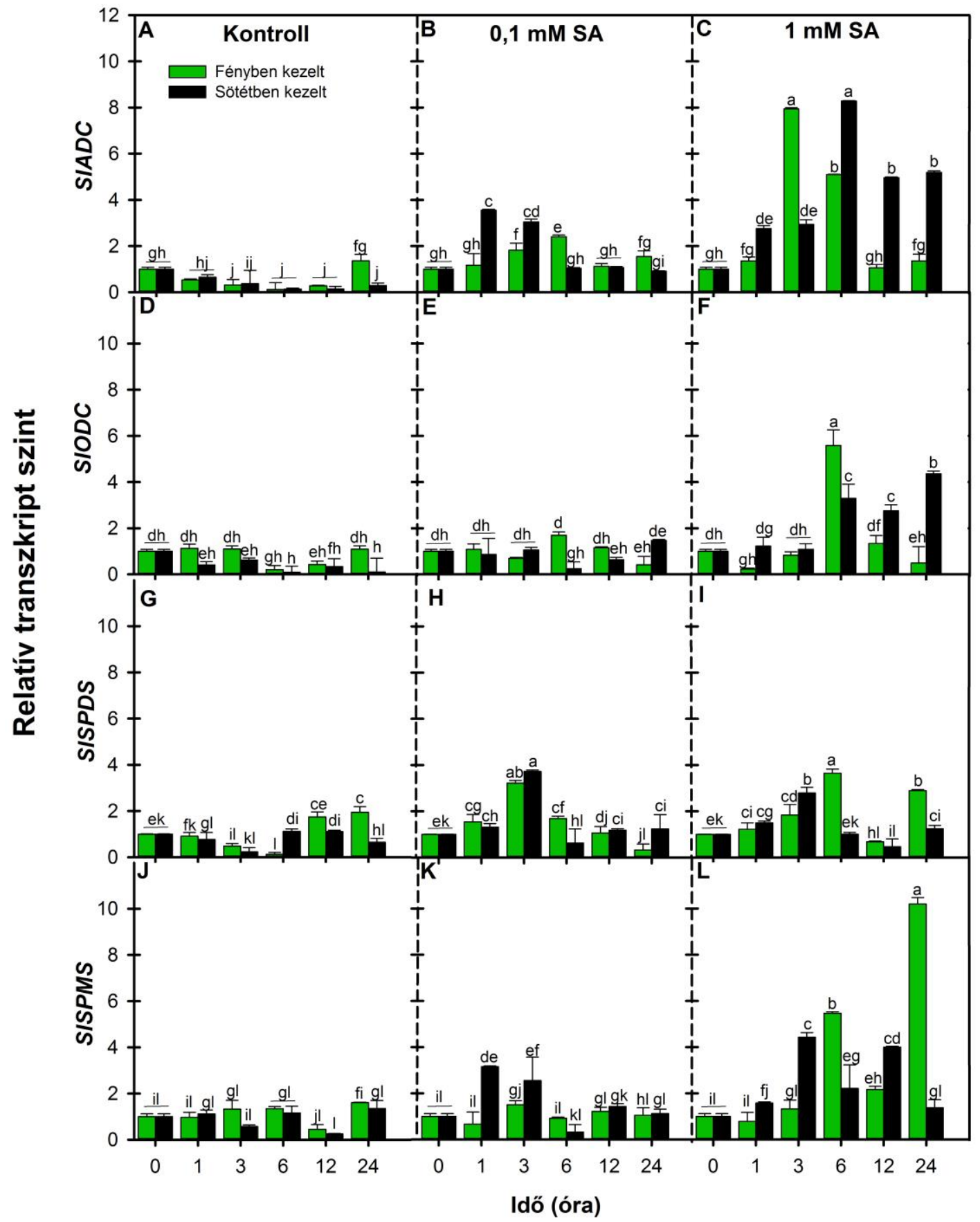

9. ábra: A PA-ok bioszintézisében szerepet játszó gének [SIADC (A, B, C); SlODC (D, E, F); SlSPDS (G, H, I); SISPMS (J, K, L)] expressziójának változásai VT paradicsom növények leveleiben kontroll körülmények között (A, D, G, J), valamint 24 óráig tartó $0,1 \mathrm{mM}(\mathrm{B}, \mathrm{E}, \mathrm{H}, \mathrm{K})$ és $1 \mathrm{mM}(\mathrm{C}, \mathrm{F}, \mathrm{I}, \mathrm{L}) \mathrm{SA}$ kezelést követően fényben $(\square)$ és sötétben ( $\square$ ) (Átlag $\pm \mathrm{SE}, \mathrm{n}=3, P \leq 0,05$ ).

\subsubsection{A PA-ok terminális lebontásában szerepet játszó enzimek aktivitásának és expressziójának változásai}

A PA-ok terminális lebontásában szerepet játszó DAO, illetve PAO enzimek aktivitása fontos szerepet játszhat a PA-ok oxidációja során fellépő apoplasztikus oxidatív robbanás kialakításában azáltal, hogy a lebontó folyamatok során melléktermékként $\mathrm{H}_{2} \mathrm{O}_{2}$ keletkezik, melynek mennyiségében bekövetkező változások hozzájárulhatnak a stressztolerancia vagy a 
sejthalál kiváltásához (Moschou és Roubelakis 2014). Ezért megvizsgáltuk a PA-ok katabolizmusban szerepet játszó két legfontosabb enzim, a DAO és a PAO aktivitásának és expressziójának változását a két általunk alkalmazott SA kezelést követően, fényben és sötétben.

Kontroll körülmények között a DAO aktivitása az első órákban csökkent, majd a 6. és 12. órára aktivitása megemelkedett. Azonban, ha a növényeket sötétben kezeltük, akkor aktivitása nagyobb mértékü csökkenést mutatott a normál fotoperióduson tartott kontroll növényekhez képest (10. ábra A). 0,1 mM SA kezelést követő 3. órában a DAO aktivitása mindkét kezelés során indukálódott, de ez a sötétben szignifikánsan magasabb volt (10. ábra B). Ezzel szemben a normál fotoperióduson történő $1 \mathrm{mM}$ SA kezelés szignifikánsan gátolta a DAO aktivitását, míg ha a növényeket sötétben kezeltük, akkor az enzim aktivitás a kezelést követő első és 24. órában mutatott szignifikáns emelkedést (10. ábra C).

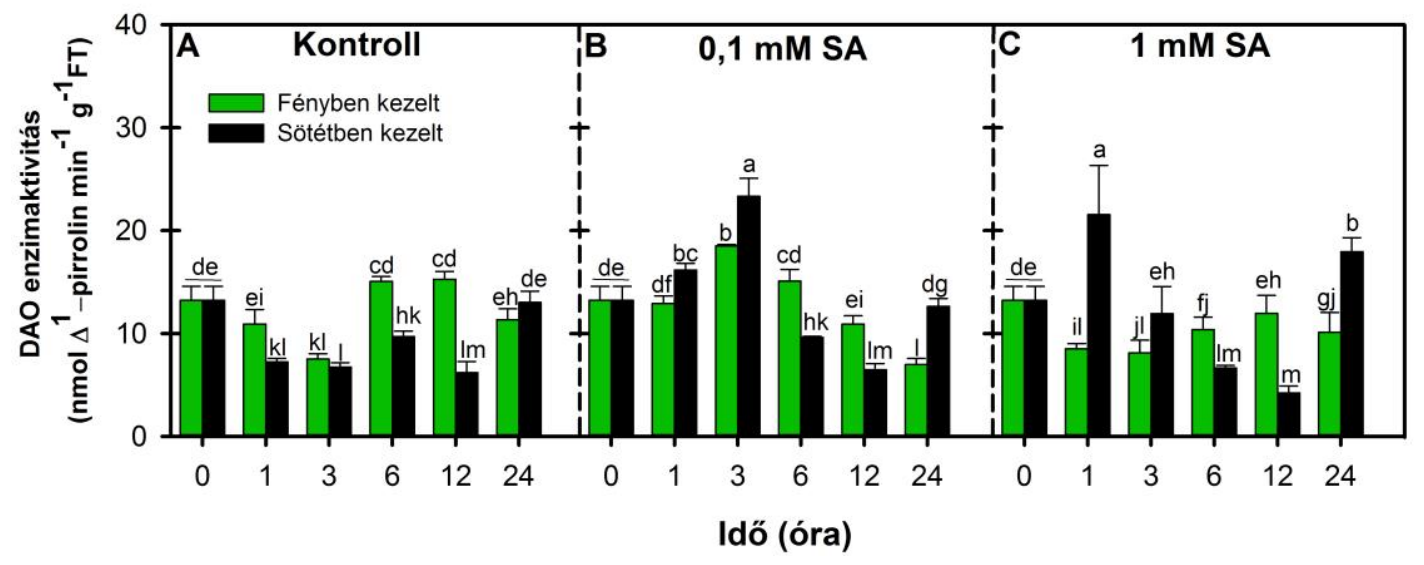

10. ábra: A DAO enzim aktivitásának változása (nmol $\Delta^{1}$-pirrolin $\min ^{-1} \mathrm{~g}^{-1} \mathrm{FT}$ ) VT paradicsom növények leveleiben kontroll körülmények között (A), valamint 24 óráig tartó $0,1 \mathrm{mM}$ (B) és $1 \mathrm{mM}$ (C) SA kezelést követően fényben ( $\square$ ) és sötétben ( $\square$ ) (Átlag $\pm \mathrm{SE}, \mathrm{n}=3, P \leq 0,05$ ).

A DAO izoenzimeket kódoló gének expressziójának változásában megfigyelhető tendencia hasonló volt az enzimaktivitásban tapasztaltakhoz. Kontroll körülmények között, az SIDAO1 és SIDAO2 gének konstans értéket mutattak, míg sötétben expressziójuk gátlódott (11. ábra A, D). Koraibb és szignifikánsan magasabb SIDAO1 és SIDAO2 expresszió volt megfigyelhető a 0,1 mM SA kezelést követő 3. órában, ha a növényeket sötétben kezeltük, míg ez az indukció normál fotoperióduson később, csak a kezelést követő 6. órában jelentkezett (11. ábra B, E). 1 mM SA kezelés hatására az izoenzimek expressziója csak a sötétben kezelt paradicsom növények leveleiben indukálódott a kezelést követő első és 24. órában (11. ábra C, F), mely indukció egybeesik az enzimaktivitásban mért maximum értékekkel. 


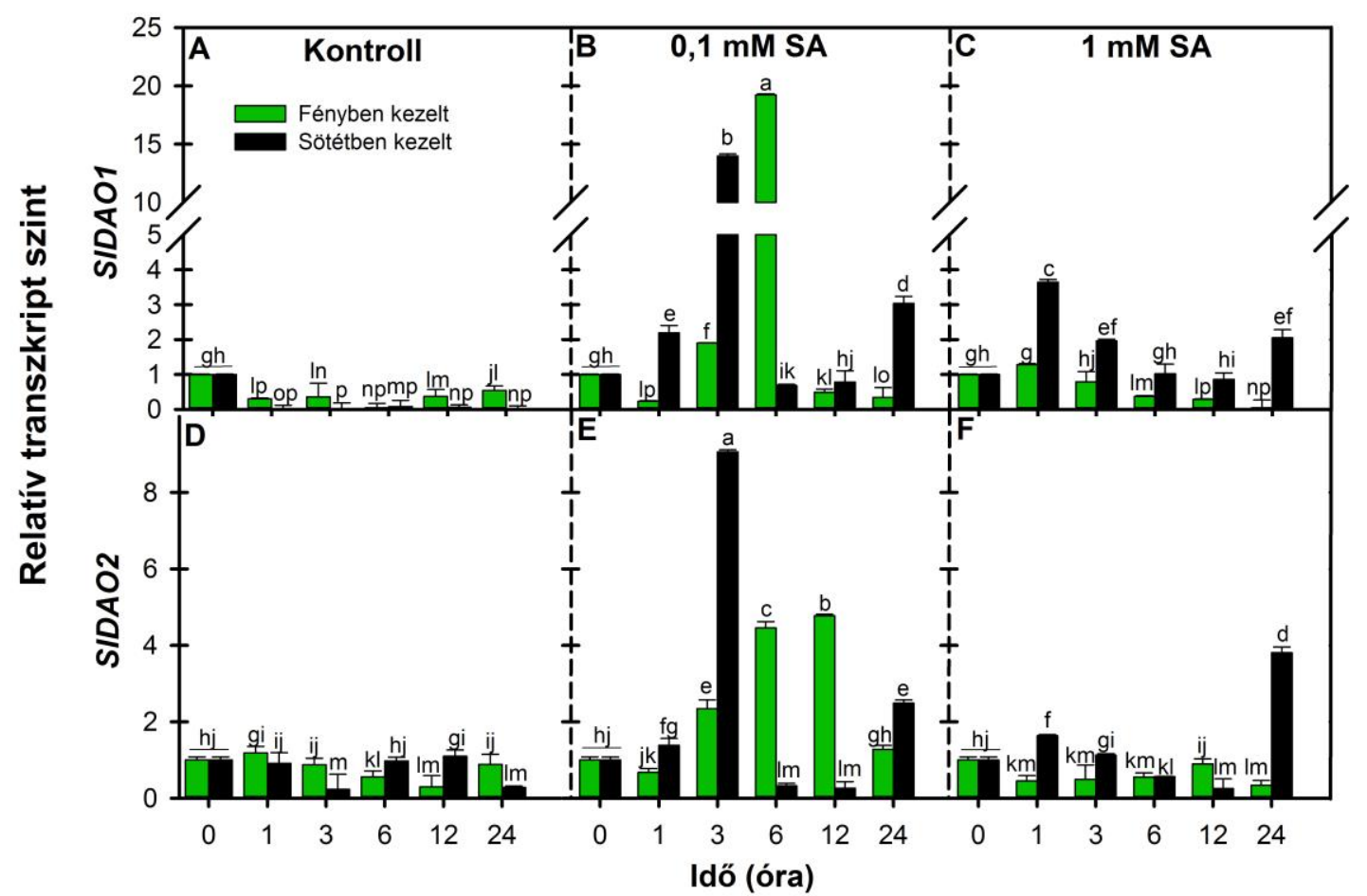

11. ábra: A PA-ok katabolizmusában szerepet játszó DAO izoenzimeket kódoló gének [SIDAO1 (A,B,C); SIDAO2 (D,E,F)] expressziójának változása VT paradicsom növények leveleiben kontroll körülmények között (A, D), valamint 24 óráig tartó $0,1 \mathrm{mM}(\mathrm{B}, \mathrm{E})$ és $1 \mathrm{mM}(\mathrm{C}, \mathrm{F}) \mathrm{SA}$ kezelést követöen fényben ( $\square$ ) és sötétben ( $\mathbf{\square})$ (Átlag $\pm \mathrm{SE}, \mathrm{n}=3, P \leq 0,05$ ).

A PAO aktivitása kontroll körülmények között a 6. órától mutatott szignifikáns emelkedést, mely emelkedés a sötétben tartott növények levelében később, a 12. órától jelentkezett (12. ábra A). Normál fotoperióduson mindkét SA kezelés indukálta a PAO aktivitását a kezelést követő 3. órában, míg sötétben csak az $1 \mathrm{mM}$ SA kezelés hatására tapasztaltunk szignifikáns emelkedést a vizsgált enzimaktivitásában (12. ábra B, C).

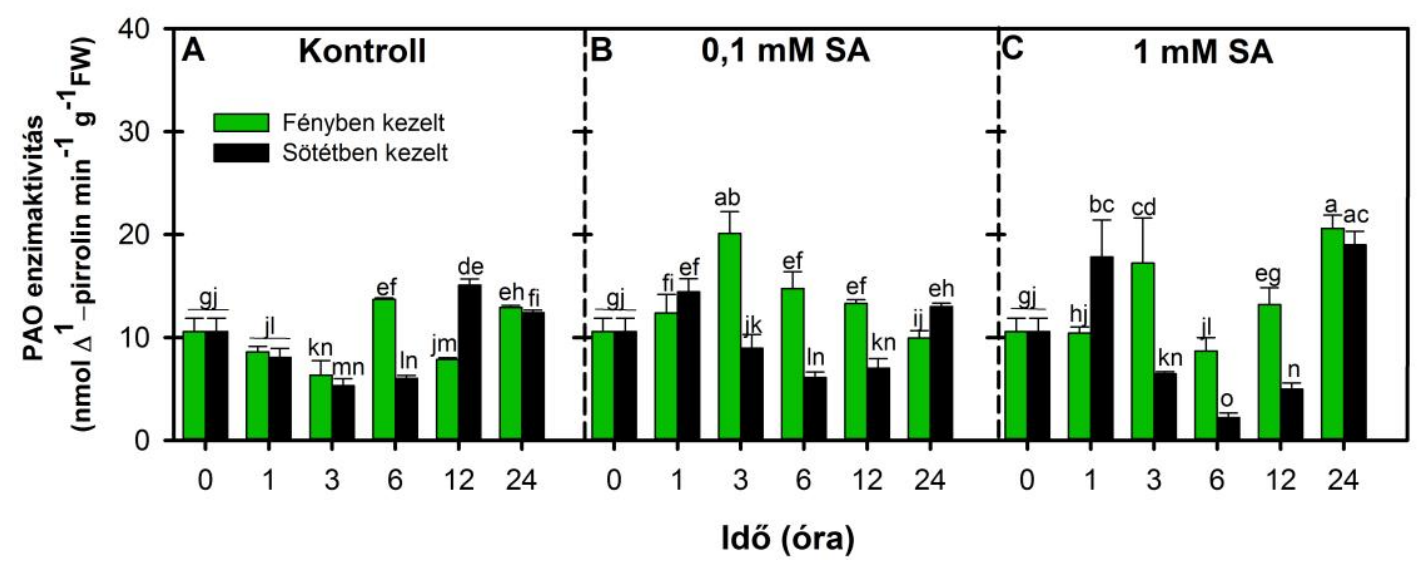

12. ábra: A PAO enzim aktivitásának változása (nmol $\Delta^{1}$-pirrolin $\min ^{-1} \mathrm{~g}^{-1} \mathrm{FT}$ ) VT paradicsom növények leveleiben kontroll körülmények között (A), valamint 24 óráig tartó $0,1 \mathrm{mM}$ (B) és $1 \mathrm{mM}(\mathrm{C})$ SA kezelést követően fényben ( $\square$ ) és sötétben ( $\square$ ) (Átlag $\pm \mathrm{SE}, \mathrm{n}=3, P \leq 0,05$ ).

A továbbiakban azt is megvizsgáltuk, hogyan változik a PAO izoenzimeket kódoló gének közül az SIPAO1 és SIPAO2 relatív transzkript szintje exogén SA kezelés hatására, fényben és 
sötétben. Kontroll körülmények között az SIPAO1 relatív transzkript szintje a 6. és 24. órában mutatott szignifikans emelkedést, míg sötétben mindkét általunk vizsgált gén expressziójában szignifikáns csökkenés volt kimutatható az idő függvényében (12. ábra A, D). Mindkét SA kezelés hatására az SIPAO1 gén expressziója mutatott szignifikánsan magasabb indukciót fényben és sötétben (13. ábra B, C, E, F). Megállapítható, hogy az idő függvényében a szubletális SA koncentráció sötétben egy késői, míg a letális koncentráció fényben egy korai relatív transzkript szint emelkedést okozott az SIPAOl gén expressziójában (13. ábra $\mathrm{B}, \mathrm{C})$. Ezzel szemben, a szubletális és a letális SA koncentrációk kismértékü, de nem szignifikáns változást okoztak az SIPAO2 gén expressziójában (13. ábra E, F).

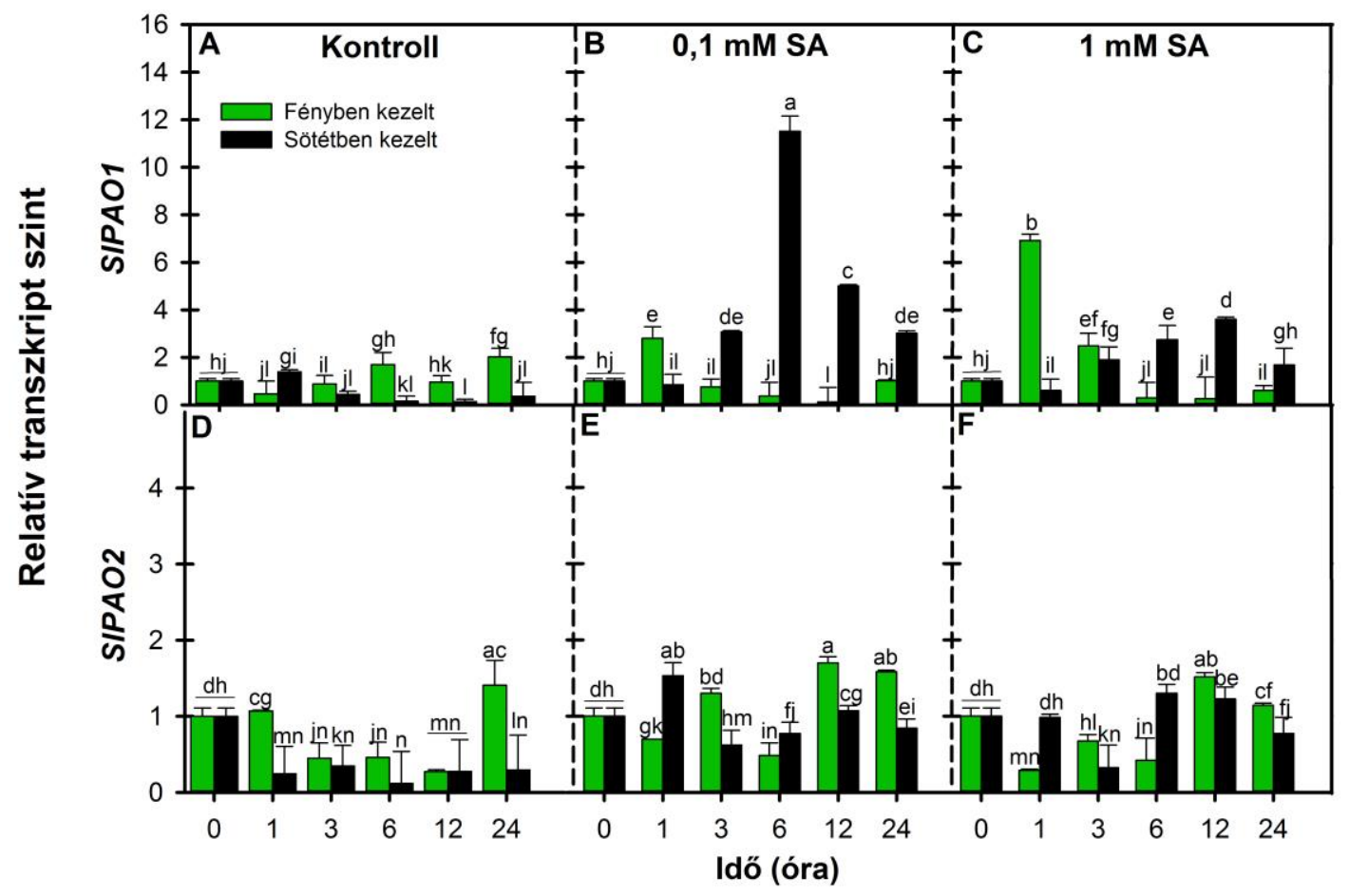

13. ábra: A PA-ok terminális katabolizmusában szerepet játszó PAO izoenzimeket kódoló gének [SlPAO1 (A,B,C); SlPAO2 (D,E,F)] expressziójának változásai VT paradicsom növények leveleiben kontroll körülmények között (A, D), valamint 24 óráig tartó $0,1 \mathrm{mM}(\mathrm{B}, \mathrm{E})$ és $1 \mathrm{mM}(\mathrm{C}, \mathrm{F})$ SA kezelést követöen fényben ( $\square$ ) és sötétben ( $\square$ ) (Átlag $\pm \mathrm{SE}, \mathrm{n}=3, P \leq 0,05$ ).

\subsubsection{A $\cdot \mathrm{O}_{2}^{-}, \mathrm{H}_{2} \mathrm{O}_{2}$ és $\mathrm{NO}$ szintek változásai}

A $\mathrm{O}_{2}{ }^{-}, \mathrm{H}_{2} \mathrm{O}_{2}$ és $\mathrm{NO}$ fontos jelátviteli komponensek az SA indukálta fiziológiai válaszokban, ugyanis az SA-ról ismert, hogy az oxidatív stressz generálásán keresztül HR-t, ezáltal pedig a sejtek halálát indukálhatja. Továbbá a PA-ok végoxidációja során keletkező $\mathrm{H}_{2} \mathrm{O}_{2}$ is hozzájárulhat az SA indukálta oxidatív stresszhez, valamint metabolizmusuk kapcsolatban állhat az NO bioszintézisével is. Mennyiségüket a fény is nagymértékben befolyásolhatja, ezért megvizsgáltuk, hogyan változik az idő függvényében a ROS, azok közül is különösen a $\mathrm{O}_{2}{ }^{-}$, 
$\mathrm{H}_{2} \mathrm{O}_{2}$, valamint az NO szintje a különböző SA kezelések fényben és sötétben történő alkalmazása során.

Az intakt levelek NBT oldatban történő inkubációja után, magasabb $\mathrm{O}_{2}{ }^{-}$mennyiséget csak a fényben történő $1 \mathrm{mM}$ SA kezelést követő első órákban figyelhettünk meg, míg ha a növényeket sötétben kezeltük kisebb mértékü $\mathrm{O}_{2}{ }^{-}$termelödést tapasztaltunk (14. ábra).

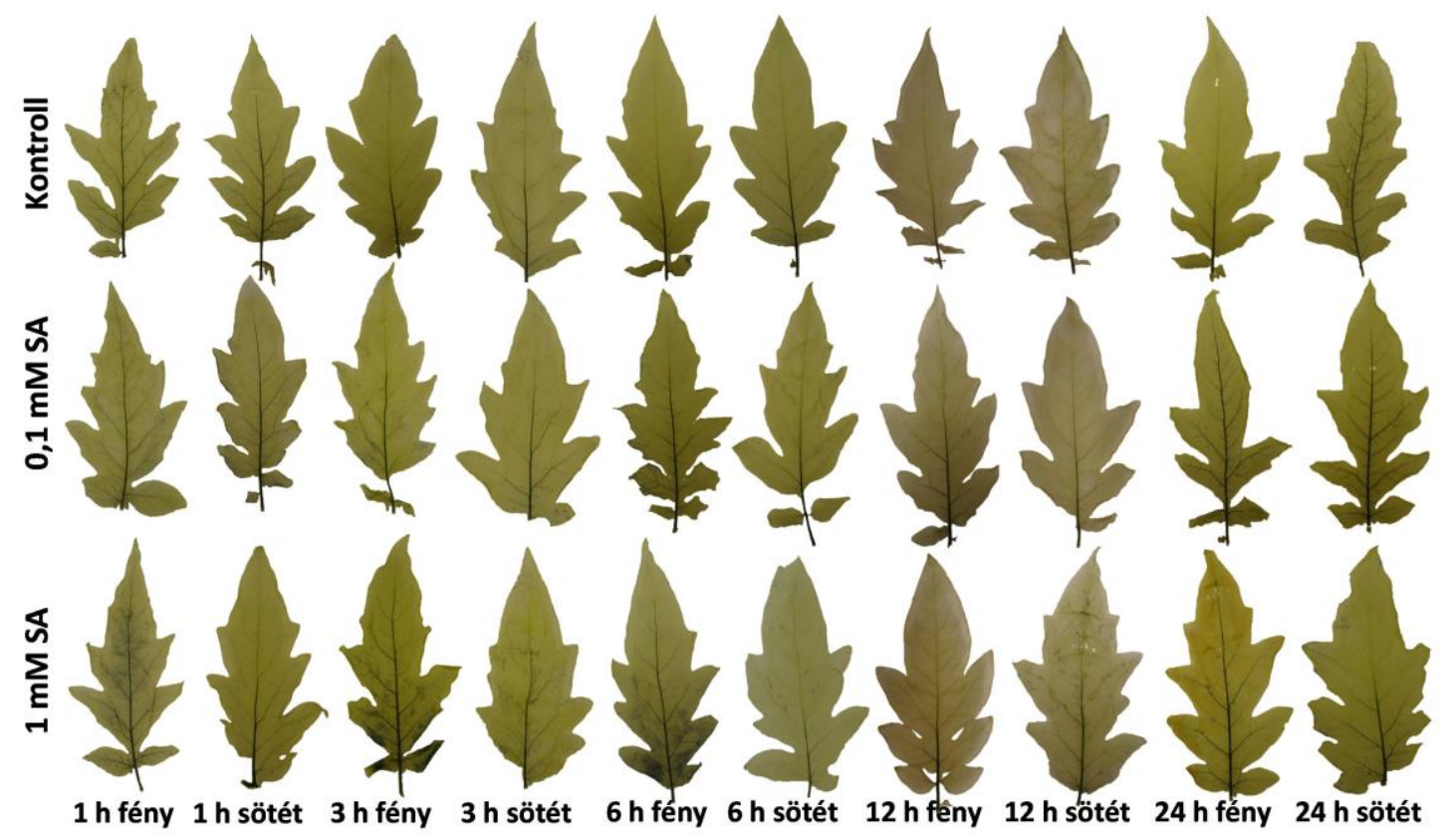

14 ábra: $\mathrm{A} \cdot \mathrm{O}_{2}{ }^{-}$termelődése NBT festés alapján VT paradicsom növények leveleiben kontroll körülmények között, valamint 24 óráig tartó $0,1 \mathrm{mM}$ és $1 \mathrm{mM}$ SA kezelést követően, fényben és sötétben. A kékes szín a $\cdot \mathrm{O}_{2}{ }^{-}$jelenlétét jelzi.

A $\mathrm{H}_{2} \mathrm{O}_{2}$ mennyisége kontroll körülmények között kismértékben emelkedett a nap folyamán, mely emelkedés a sötétben történő kezelés során kisebb mértékü volt (15. ábra A). Mindkét, általunk vizsgált SA koncentráció idő- és koncentráció-függő módon növelte meg a $\mathrm{H}_{2} \mathrm{O}_{2}$ mennyiségét, mely hatás a sötétben kezelt növények leveleiben alacsonyabb volt (15. ábra B, C). Normál fotoperióduson történő $1 \mathrm{mM}$ SA a 0,1 mM SA kezeléshez hasonlóan fokozta a $\mathrm{H}_{2} \mathrm{O}_{2}$ mennyiségét az idő függvényében, azonban ez az emelkedés már a kezelést követő első órától jelentkezett, és jóval nagyobb értékeket ért el, mint a kisebb SA koncentrációnál. Ezzel szemben a sötétben kezelt növények levelében a $\mathrm{H}_{2} \mathrm{O}_{2}$ mennyisége később, a kezelést követő 6. órától mutatott szignifikáns emelkedést. Továbbá megfigyelhető, hogy fényben a $\mathrm{H}_{2} \mathrm{O}_{2}$ mennyisége a letális $\mathrm{SA}$ kezelés hatására kettős csúcsot mutatott a kezelést követő 3. és 24. órában, mely kettős csúcs a sötétben kezelt növények leveleiben elmaradt (15. ábra C). 


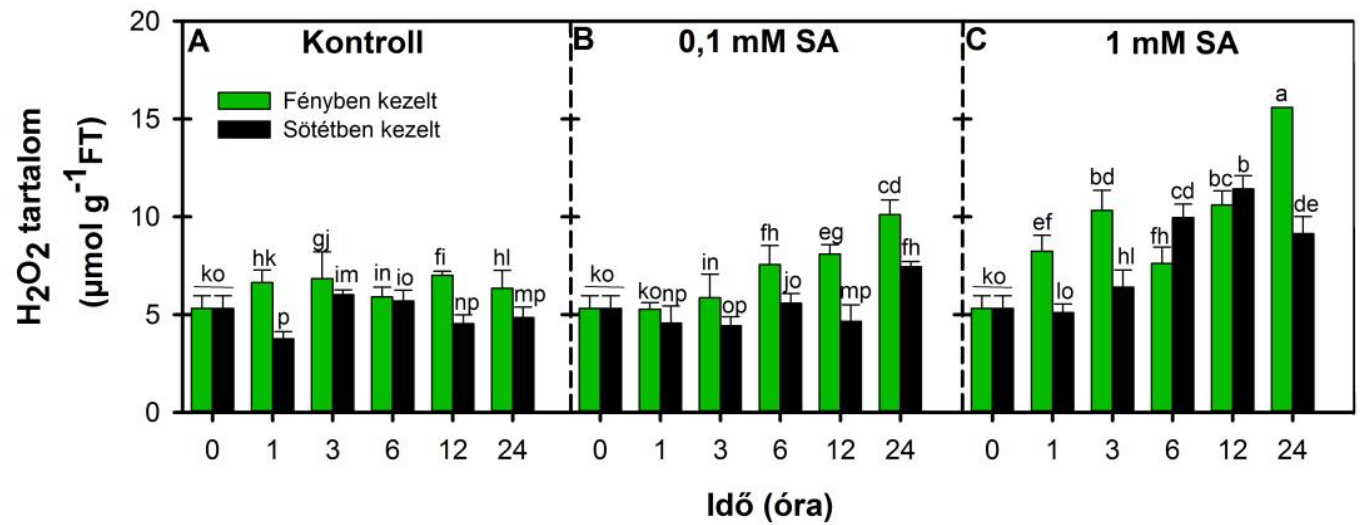

15. ábra: $A \mathrm{H}_{2} \mathrm{O}_{2}$ tartalom változása $\left(\mu \mathrm{mol} \mathrm{g}^{-1} \mathrm{FT}\right)$ VT paradicsom növények leveleiben kontroll körülmények között (A), valamint 24 óráig tartó $0,1 \mathrm{mM}$ (B) és $1 \mathrm{mM}$ (C) SA kezelést követően fényben ( $\square$ ) és sötétben ( $\square$ ) (Átlag $\pm \mathrm{SE}, \mathrm{n}=3, P \leq 0,05$ ).

Az NO termelődése kontroll, valamint 0,1 mM SA-val kezelt VT növények leveleiben kismértékü csökkenést mutatott a nap folyamán mindkét külső környezetben (16. ábra A, B). Ezzel szemben az 1 mM SA kezelés hatására a 6. órától szignifikánsan nőtt az NO termelődése fényben, míg ez az emelkedés a sötétben kezelt növények leveleiben nem volt tapasztalható (16. ábra C).

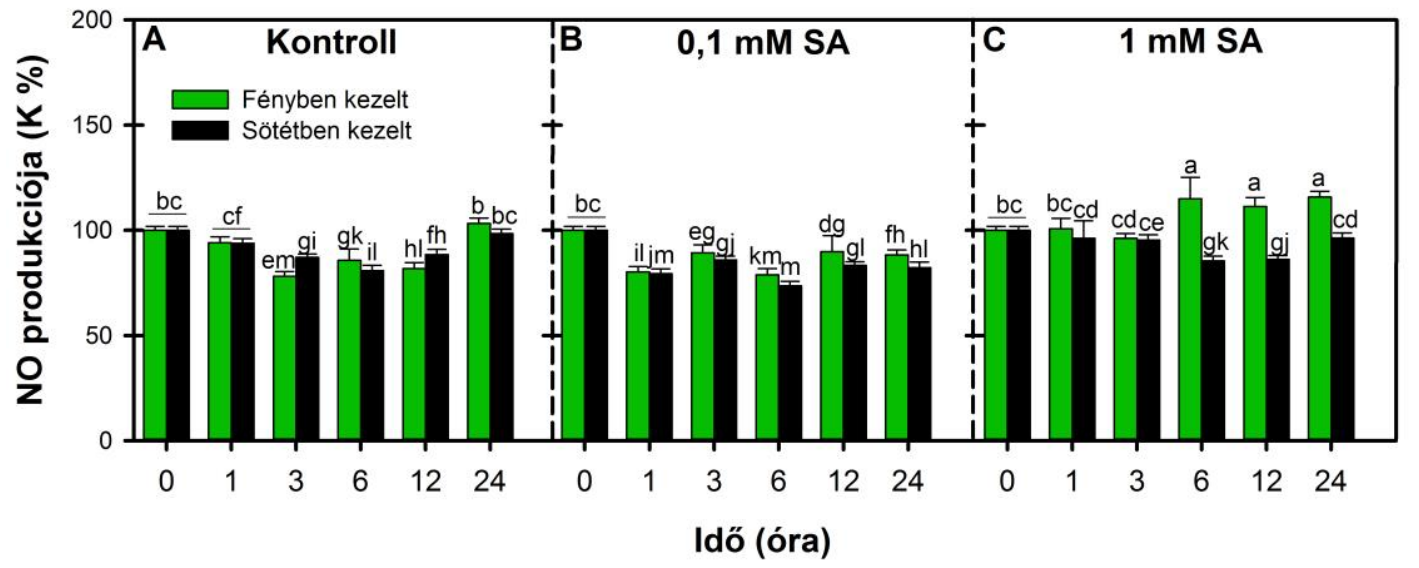

16. ábra: $\mathrm{Az} N \mathrm{NO}$ termelődésének változása $(\mathrm{K} \%)$ VT paradicsom növények leveleiben kontroll körülmények között (A), valamint 24 óráig tartó $0,1 \mathrm{mM}$ (B) és $1 \mathrm{mM}$ (C) SA kezelést követően fényben ( $\square$ ) és sötétben ( $\square$ ) (Átlag $\pm \mathrm{SE}, \mathrm{n}=10, P \leq 0,05$ ).

A kapott eredmények alapján elmondható, hogy a letális SA normál fotoperióduson nevelt növényekben egyidejü $\mathrm{H}_{2} \mathrm{O}_{2}$ és $\mathrm{NO}$ felhalmozódást eredményez a kezelést követő 6 . óra után. Ezt az egyidejü oxidatív és nitrozatív stresszt egy korábbi $\cdot^{-}{ }^{-}$képződés elözi meg a kezelést követő első órákban, mely változások sötétben kisebb mértékben $\left(\mathrm{H}_{2} \mathrm{O}_{2}, \mathrm{O}_{2}{ }^{-}\right)$vagy nem $(\mathrm{NO})$ jelentkeznek késleltetve ezáltal az SA indukálta sejthalált a VT paradicsom növények leveleiben. 


\subsubsection{A NOX enzim aktivitása és az SIRBOH1 gén expressziója}

A biotikus stresszben kulcsfontosságú NOX enzimet és az öt kódoló paradicsom gént, az SIRBOHI relatív transzkript szintjének változását is megvizsgáltuk az idő függvényében az SA kezeléseket követően. Mindkét általunk alkalmazott SA koncetráció a kezelés kezdeti szakaszában már indukálta a NOX aktivitását, azonban a letális SA koncentráció hamarabb és nagyobb mértékben tette azt (17. ábra B, C). Megállapítható továbbá, hogy normál fotoperióduson történő $1 \mathrm{mM}$ SA kezelés hatására a NOX enzim az első hat órában, majd egy átmeneti csökkenést követően, a 24. órában mutatott szignifikánsan magasabb aktivitást a kezeletlen kontrollhoz és a megfelelő sötétben történő kezeléshez képest (17. ábra C). A kapott eredmények alapján megállapítható, hogy a letális $\mathrm{SA}$ indukálta korai $\cdot \mathrm{O}_{2}{ }^{-}$termelödésében fontos szerepe lehet a PM lokalizált NOX aktivitásának.

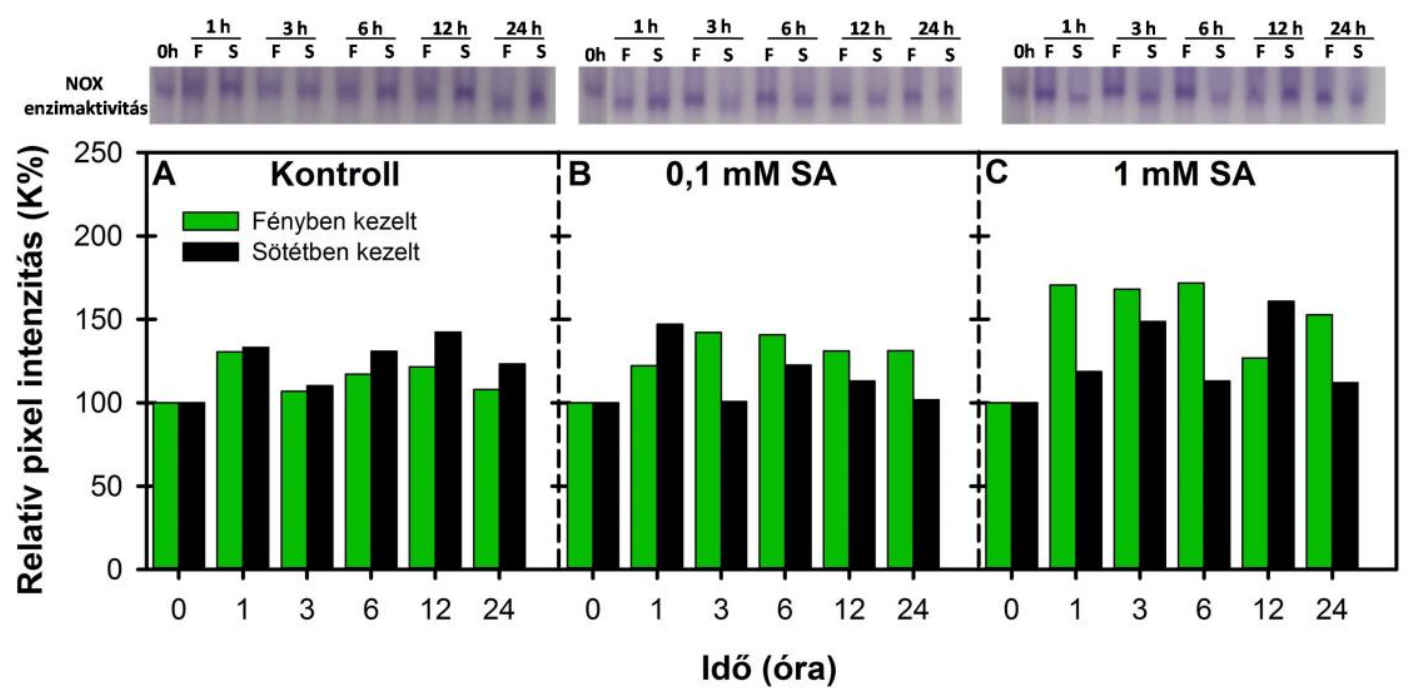

17. ábra: NOX aktivitásának változása natív gélben vizsgálva (relatív pixel intenzitás) VT paradicsom növények leveleiben kontroll körülmények között (A), valamint 24 óráig tartó $0,1 \mathrm{mM}$ (B) és $1 \mathrm{mM}(\mathrm{C})$ SA kezelést követően fényben $(\square)$ és sötétben $(\boldsymbol{\square})$. Az itt látható adatok egy reprezentatív kísérlet eredményei, melyet három alkalommal ismételtünk meg.

Az SIRBOH1 gén expressziójának vizsgálata során megállapítható, hogy fényben mindkét SA kezelés hatására a vizsgált gén transzkript szintje a kezelést követő első órákban és egy átmeneti csökkenést követően a 24. órában mutatott szinifikáns emelkedést (18. ábra B, C). Továbbá az is, hogy a növények letális SA-val történő kezelése a sötétben az első és 12. órában mutatott szignifikáns indukciót (18. ábra C). 


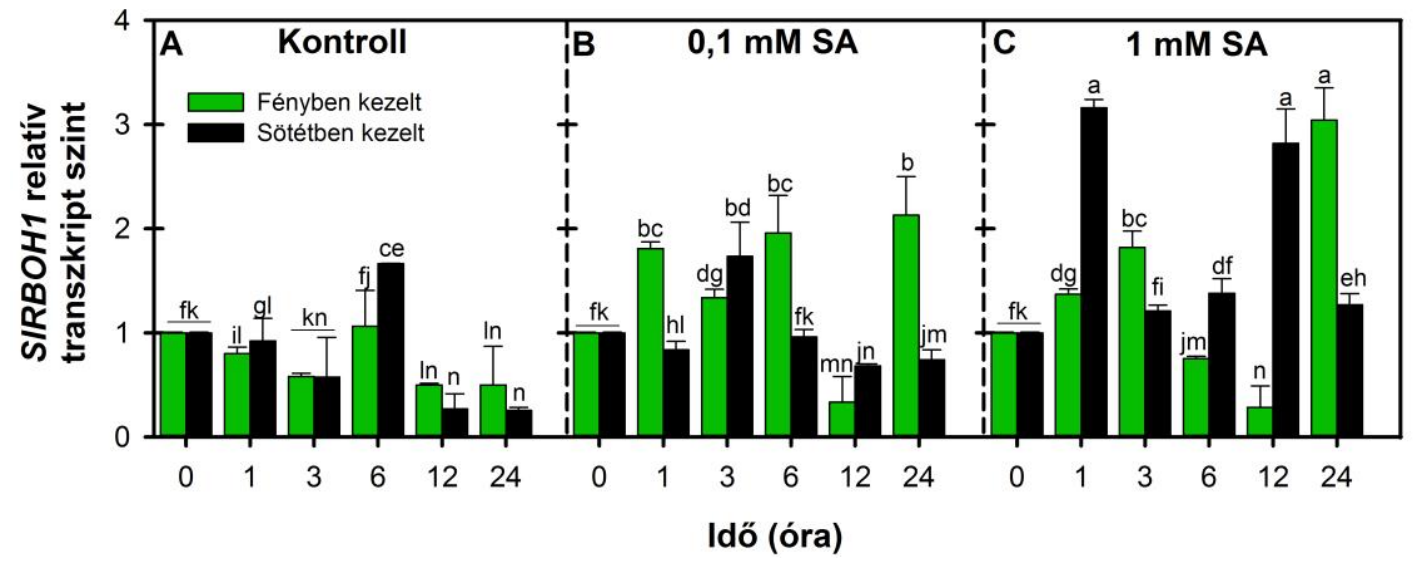

18. ábra: Az apoplasztikus oxidatív robbanásban szerepet játszó NADPH-oxidáz enzimet kódoló gén (SlRBOH1) expressziójának változása VT paradicsom növények leveleiben kontroll körülmények között (A), valamint 24 óráig tartó $0,1 \mathrm{mM}$ (B) és $1 \mathrm{mM}(\mathrm{C})$ SA kezelést követően fényben $\square$ ) és sötétben ( $\mathbf{\square})$ (Átlag $\pm \mathrm{SE}, \mathrm{n}=3, P \leq 0,05$ ).

\subsubsection{A szuperoxid-dizmutáz aktivitása és a különböző izoenzimeket kódoló gének expressziója}

A $\cdot \mathrm{O}_{2}{ }^{-}$és a $\mathrm{H}_{2} \mathrm{O}_{2}$ hatékony eliminálásához az antioxidáns enzimek összehangolt müködése szükséges. A különböző kompartmentumokban képződött $\mathrm{O}_{2}{ }^{-}$a $\mathrm{SOD}$ enzim müködése révén gyorsan átalakul $\mathrm{H}_{2} \mathrm{O}_{2}$-dá. Ezért megvizsgáltuk, hogyan hatnak a különböző SA koncentrációk a SOD aktivitására és a SOD izoenzimeket kódoló gének (SIMnSOD, SlFeSOD és $S l C u / Z n S O D)$ expressziójára, normál fotoperióduson és sötétben történő kezelések során.

A kapott eredmények alapján elmondható, hogy mindkét SA kezelés kismértékben, de szignifikánsan emelte a levelek SOD aktivitását a fényben a 24 órás mintákban (19. ábra B, C). Ezzel szemben, ha a növényeket sötétben kezeltük, a sötétben lévő kontrollhoz képest csak minimális változásokat tapasztaltunk mindkét SA kezelés esetén (19. ábra A, B, C).

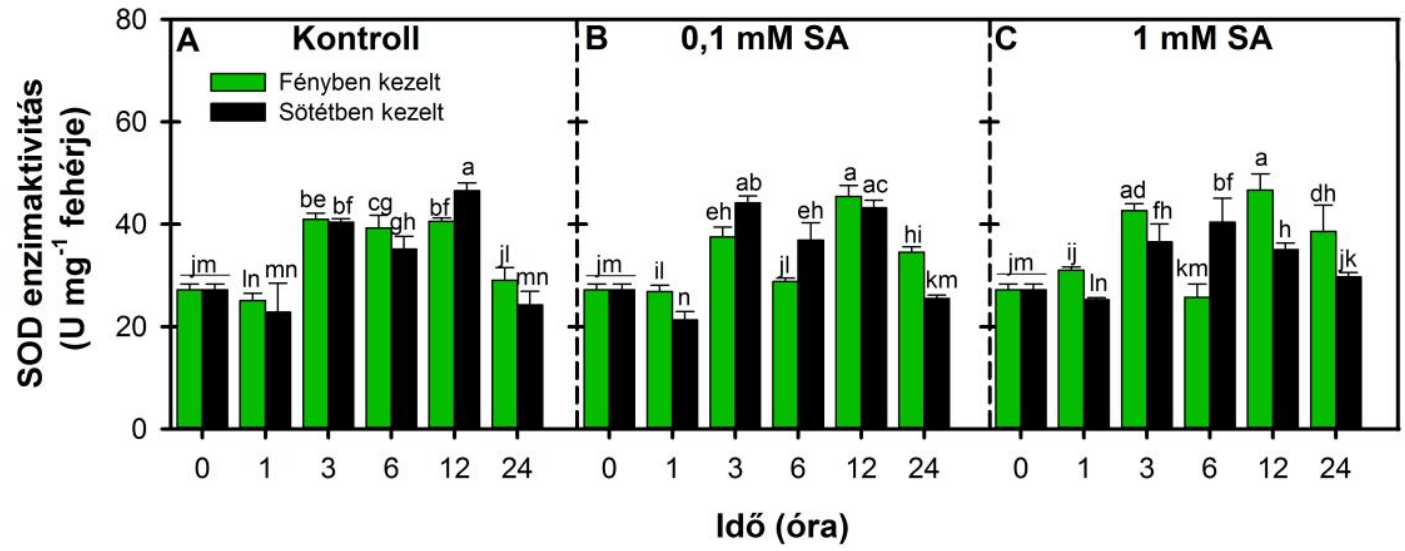

19. ábra: A SOD aktivitásának változása $\left(\mathrm{U} \mathrm{mg}^{-1}\right.$ fehérje) VT paradicsom növények leveleiben kontroll körülmények között (A), valamint 24 óráig tartó $0,1 \mathrm{mM}$ (B) és $1 \mathrm{mM}$ (C) SA kezelést követően fényben ( $\square$ ) és sötétben ( $\square$ ) (Átlag $\pm \mathrm{SE}, \mathrm{n}=3, P \leq 0,05$ ). 
Mivel a SOD izoformái csaknem minden sejtkompartmentumban előfordulnak, így az adott kompartmentumban kulcsfontosságúak a $\mathrm{H}_{2} \mathrm{O}_{2}$ mennyiségének szabályozásában is. Kísérleteink során a mitokondriális SIMnSOD, valamint a kloroplasztiszban megtalálható SlFeSOD és SlCu/ZnSOD gének relatív transzkript szintjének időbeli változásait is megvizsgáltuk exogén SA kezelések hatására, fényben és sötétben egyaránt.

Kontroll körülmények között, az általunk vizsgált három izoformát kódoló gén közül az SlFeSOD relatív transzkript szintje mutatott szignifikáns emelkedést a sötétkezelést követő 6. és 12. órában (20. ábra D). Fényben történő szubletlális SA kezelés hatására mindhárom gén relatív transzkript szintje állandó értéken maradt vagy az idő függvényében csökkent, míg, ha a növényeket sötétben kezeltük mindhárom gén expressziója indukciót mutatott a kezelést követő 3. órában (20. ábra B, E, H). Letális SA fényben történő alkalmazása során szignifikáns indukciót az SlMnSOD, valamint az SlCu/ZnSOD gének expressziójában tapasztaltunk, míg sötétben kisebb mértékü indukció volt megfigyelhető ugyanennél az SA koncentrációnál (20. ábra C, I).

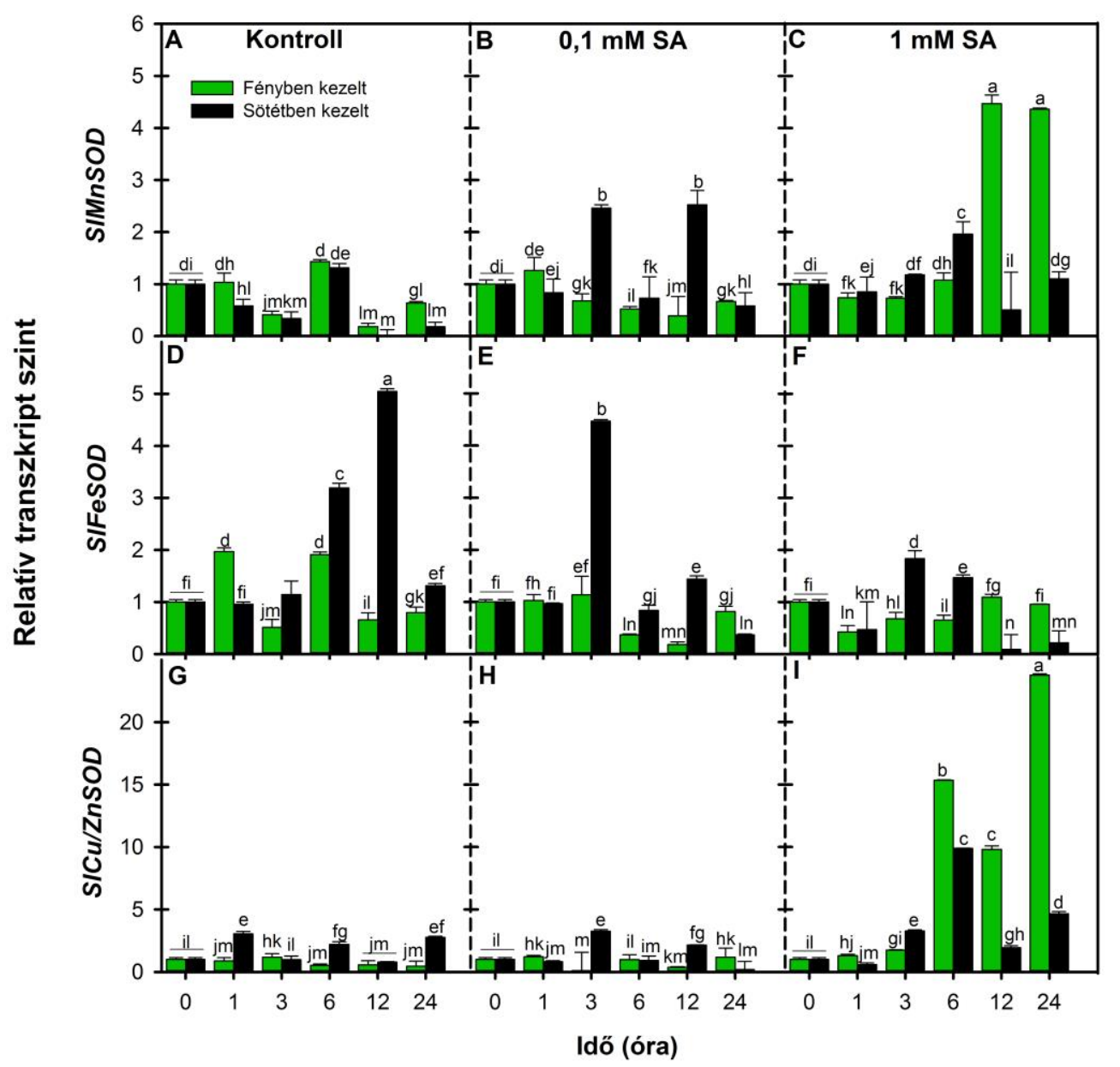

20. ábra: A SOD izoenzimeket kódoló gének [SIMnSOD (A, B, C); SlFeSOD (D, E, F); SlCu/ZnSOD $(\mathrm{G}, \mathrm{H}, \mathrm{I})$ ] expressziójának változása VT paradicsom növények leveleiben kontroll körülmények között (A, D, G), valamint 24 óráig tartó $0,1 \mathrm{mM}(\mathrm{B}, \mathrm{E}, \mathrm{H})$ és $1 \mathrm{mM}(\mathrm{C}, \mathrm{F}, \mathrm{I}) \mathrm{SA}$ kezelést követően fényben ( $\square$ ) és sötétben ( $\square$ ) (Átlag $\pm \mathrm{SE}, \mathrm{n}=3, P \leq 0,05$ ). 


\subsubsection{A kataláz aktivitása és a különböző izoenzimeket kódoló gének expressziója}

A KAT az egyik legfontosabb, a sejtek peroxiszómájában található $\mathrm{H}_{2} \mathrm{O}_{2}$-ot vízzé és molekuláris oxigénné közvetlenül átalakító enzim, ezért fontos szereppel bír az SA indukálta $\mathrm{H}_{2} \mathrm{O}_{2}$ szint kialakításában, ezáltal pedig a védelmi mechanizmusok vagy a sejthalál indukciójában. Éppen ezért megvizsgáltuk, hogyan változik a KAT aktivitása, valamint az izoenzimeit kódoló gének (SlKAT1, SlKAT2 és SlKAT3) expressziója a különböző SA kezelések hatására, fényben és sötétben.

Kontroll körülmények között a KAT enzim napi ritmust mutatott, míg, ha a növényeket sötétben tartottuk aktivitása a 6 . óráig azonos volt a normál fotoperióduson tartott növényekben mérhető aktivitásokkal, azonban a 12. órától ez folyamatos csökkenést produkált (21. ábra A). Mindkét általunk használt SA koncentráció fényben és a sötétben hasonló tendenciával csökkentette a KAT aktivitását (21. ábra B, C).

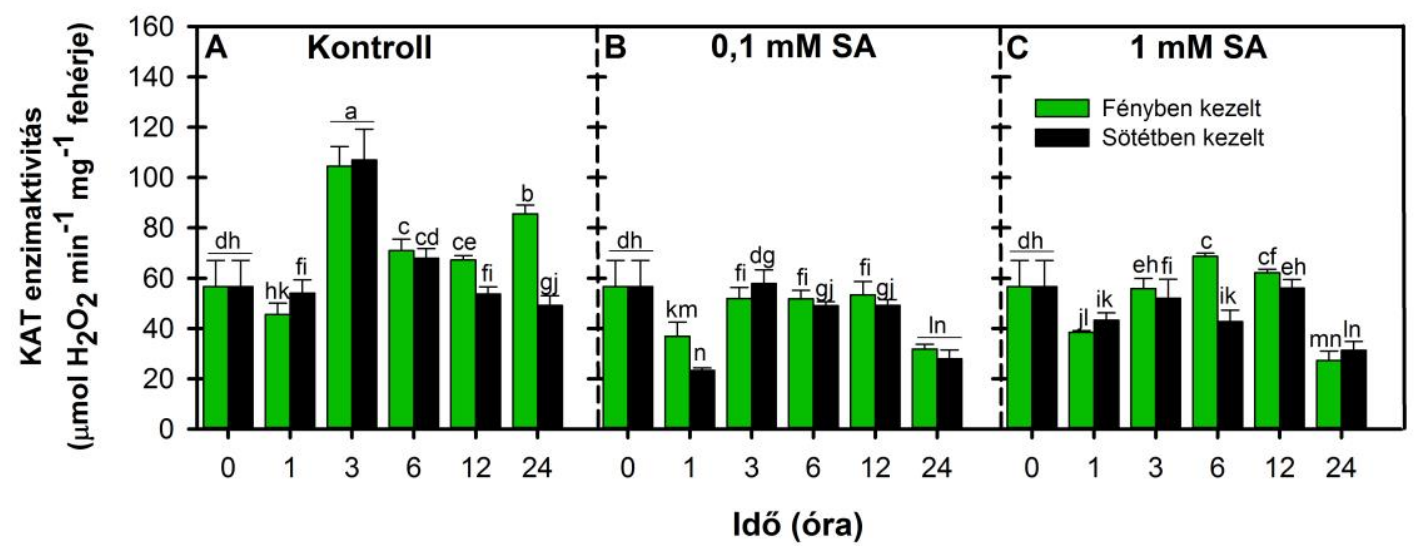

21. ábra: A KAT enzim aktivitásának változása ( $\mu \mathrm{mol} \mathrm{H}_{2} \mathrm{O}_{2} \mathrm{~min}^{-1} \mathrm{mg}^{-1}$ fehérje) VT paradicsom növények leveleiben kontroll körülmények között (A), valamint 24 óráig tartó 0,1 mM (B) és $1 \mathrm{mM}$ (C) SA kezelést követően fényben $(\square)$ és sötétben ( $\square$ ) (Átlag \pm SE, $n=3, P \leq 0,05$ ).

Kontroll körülmények között az általunk vizsgált 3 KAT izoenzimet kódoló gén közül az SIKAT3 relatív transzkript szintje a 3. órában egy átmeneti szignifikáns emelkedést mutatott, mely emelkedés a 24. órában is megmaradt. A KAT expressziójának cirkadián ritmusa is itt a legerőteljesebb. Sötétben történő kezelés hatására az SlKAT3 gén expressziója kisebb mértékben, bár hamarabb, már a kezelést követő első órában indukálódott a normál fotoperióduson tartott növényekhez képest (22. ábra G). 0,1 mM SA kezelés hatására normál fotoperióduson csak az SIKAT3 gén expressziójában tapasztaltunk szignifikáns csökkenést míg, ha a növényeket sötétben kezeltük mindhárom gén expressziója indukálódott a kezelést követő 3. és/vagy 12. órában (22. ábra B, E, H, G). Ezzel szemben, ha a növényeket $1 \mathrm{mM} \mathrm{SA-val}$ kezeltük, az SIKAT1 és SIKAT2 gének expressziója kontroll értékeket, míg az SIKAT3 gén 
relatív transzkript szintje szignifikáns csökkenést mutatott a kontrollhoz képest fényben és sötétben egyaránt (22. ábra C, F, I).

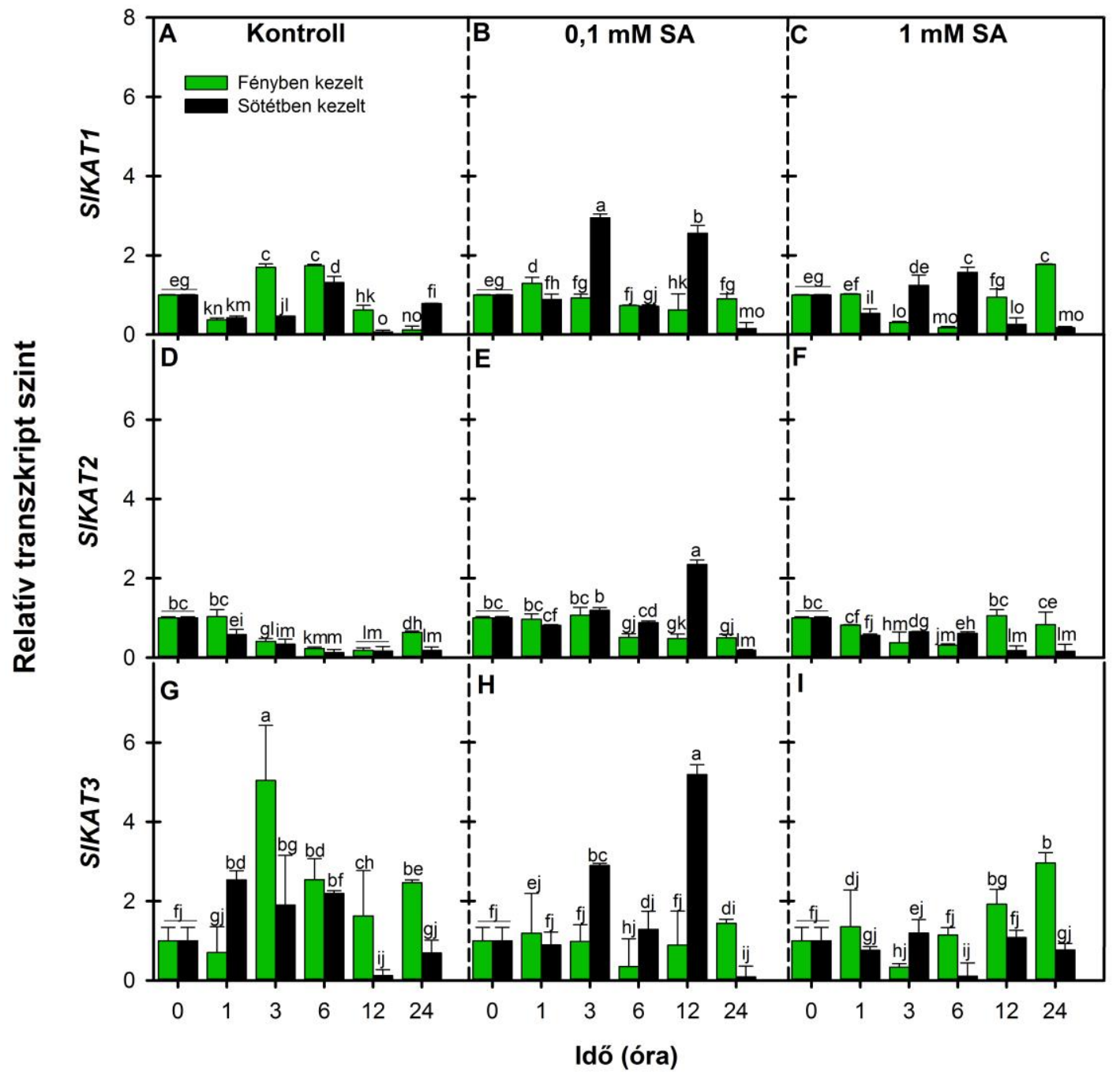

22. ábra: A KAT izoenzimeket kódoló gének [SIKAT1 (A, B, C); $\operatorname{SlKAT2~(D,~E,~F);~} \operatorname{SlKAT3~(G,~H,~I)]~}$ expressziójának változása VT paradicsom növények leveleiben kontroll körülmények között $(A, D, G)$, valamint 24 óráig tartó $0,1 \mathrm{mM}(\mathrm{B}, \mathrm{E}, \mathrm{H})$ és $1 \mathrm{mM}(\mathrm{C}, \mathrm{F}, \mathrm{I}) \mathrm{SA}$ kezelést követöen fényben ( $\square)$ és

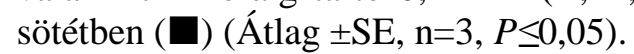

\subsubsection{Az aszkorbát-peroxidáz enzim aktivitása és a különböző izoenzimeket kódoló gének expressziói}

A következőkben megvizsgáltuk az aszkorbát-glutation ciklus egyik elemeként ismert, a celluláris $\mathrm{H}_{2} \mathrm{O}_{2}$ közvetlen lebontásában fontos szerepet játszó APX aktivitásának és az izoenzimeit kódoló gének (SlAPX1 és SlAPX2) relatív transzkript szintjének különböző SA kezelések hatására történő változásait az idő függvényében, normál fotoperióduson és sötétben (23. és 24. ábra).

Az APX aktivitása mindkét SA kezelést követő első órában szignifikáns csökkenést mutatott a megfelelő kezeletlen kontrollhoz képest (23. ábra B, C), mely csökkenés a KAT 
enzim gátlásához volt hasonló (21. ábra B, C). Ugyanakkor az $1 \mathrm{mM}$ SA kezelés hatására szignifikáns aktivitásemelkedést csak fényben tapasztaltunk (23. ábra C).

A kapott eredmények alapján elmondható, hogy az általunk vizsgált antioxidáns enzimek közül az APX aktivitása mutatta a legnagyobb fény- és koncentráció-függő változást az SA kezeléseket követően, továbbá az, hogy a KAT és az APX enzimek aktivitáscsökkenése nagymértékben hozzájárulhatott a $0,1 \mathrm{mM}$ és $1 \mathrm{mM}$ SA kezeléseket követő első $\mathrm{H}_{2} \mathrm{O}_{2}$ csúcs kialakításahoz a vad típusú AC paradicsom növények leveleiben.

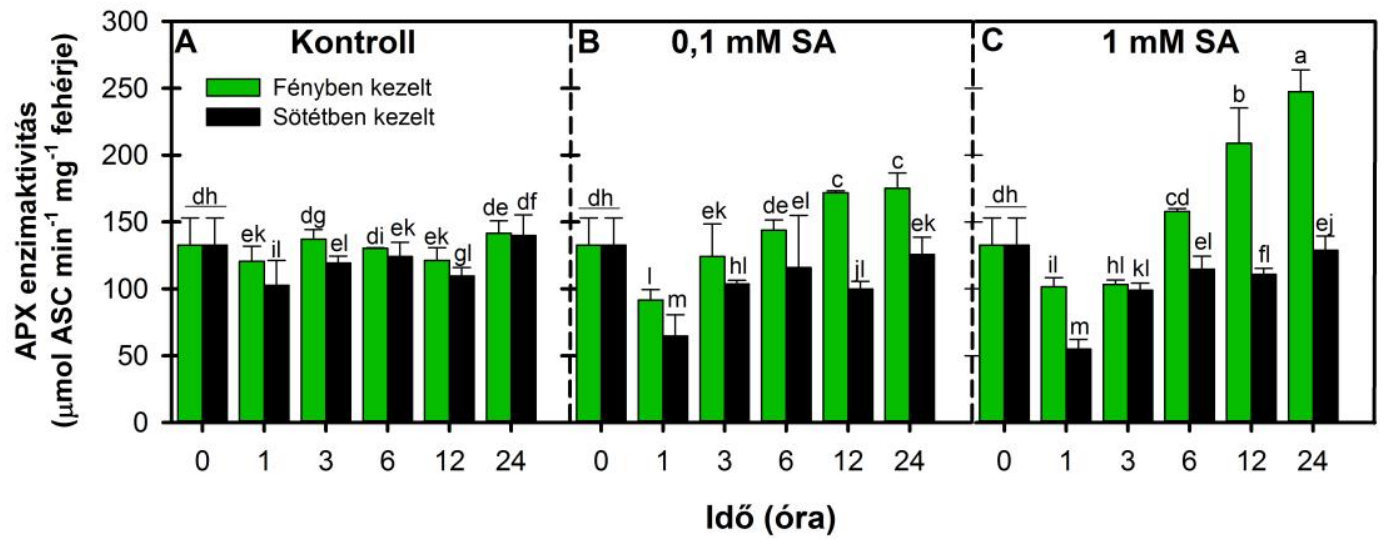

23. ábra: Az APX aktivitásának változása ( $\mu$ mol $\mathrm{ASC} \min ^{-1} \mathrm{mg}^{-1}$ fehérje) VT paradicsom növények leveleiben kontroll körülmények között (A), valamint 24 óráig tartó $0,1 \mathrm{mM}$ (B) és $1 \mathrm{mM}$ (C) SA kezelést követően fényben ( $\square$ ) és sötétben (ם) (Átlag $\pm \mathrm{SE}, \mathrm{n}=3, P \leq 0,05$ ).

Az APX aktivitásához hasonló eredményeket kaptunk, ha a citoszolikus lokalizáltságú APX izoenzimeket kódoló gének expresszióját vizsgáltuk (24. ábra). Kontroll körülmények között az SIAPX1 és SlAPX2 gének relatív transzkript szintjei szignifikáns csökkenést mutattak a nap folyamán, mely csökkenés sötétben nagyobb mértékü volt (24. ábra A, D). A szubletális SA fényben történő alkalmazása során nem tapasztaltunk szignifikáns változást az SlAPX1 és SlAPX2 gének expressziójában, míg ha a növényeket sötétben kezeltük, szignifikáns emelkedést mértünk a kezelést követő 3. és 12. órában (24. ábra B, E). Ezzel szemben fényben történő $1 \mathrm{mM}$ SA kezelés hatására mindkét izoenzim expressziójában szignifikáns növekedés tapasztalható a kezelést követő 6. órától a kezelés végéig, mely emelkedés sötétben hamarabb, már a kezelést követő 3. órától, de rövidebb ideig, csak a kezelés 6. órájáig jelentkezett (24. ábra C, F). 


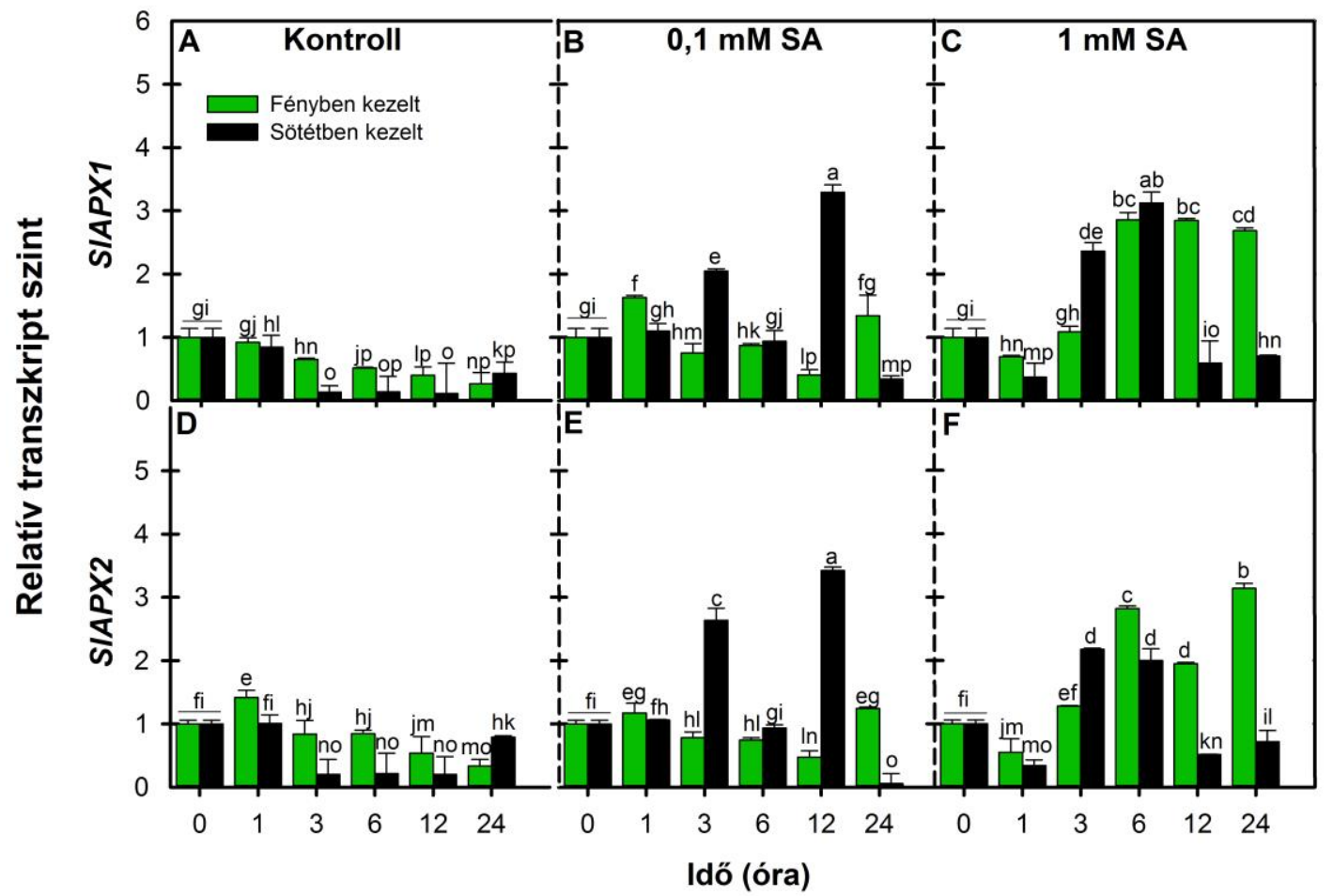

24. ábra: Az APX izoenzimeket kódoló gének [SIAPX1 (A, B, C); SlAPX2 (D, E, F)] expressziójának változása VT paradicsom növények leveleiben kontroll körülmények között (A, D), valamint 24 óráig tartó $0,1 \mathrm{mM}(\mathrm{B}, \mathrm{E})$ és $1 \mathrm{mM}(\mathrm{C}, \mathrm{F}) \mathrm{SA}$ kezelést követően fényben ( $\square)$ és sötétben ( $\square)$ (Átlag $\pm \mathrm{SE}$, $\mathrm{n}=3, P \leq 0,05)$.

\subsubsection{A gvajakol-peroxidáz enzim aktivitása}

Megvizsgáltuk a $\mathrm{H}_{2} \mathrm{O}_{2}$ bontásában ugyancsak fontos szereppel bíró POD aktivitását is, amely kontroll körülmények között szintén napi ciklust mutatott, ami a sötétben tartott növények esetében is megmaradt (25. ábra A). A szubletális SA normál fotoperióduson kismértékü aktivitásemelkedést okozott a kontrollhoz képest, mely emelkedés nem volt megfigyelhető, ha a növényeket sötétben kezeltük (25. ábra B). $1 \mathrm{mM}$ SA normál fotoperióduson a kezelést követő 12. órától szignifikáns POD aktivitásemelkedést okozott, míg sötétben szignifikáns emelkedést csak a kezelést követő 24. órában tapasztaltunk, mely azonban kisebb mértékü volt a fényben mért adatokhoz képest (25. ábra C).

A három általunk vizsgált, $\mathrm{H}_{2} \mathrm{O}_{2}$ bontásában szerepet játszó enzim kapcsán megállapítható, hogy sötétben a POD aktivitásának lehet elsősorban fontos szerepe az SA indukálta oxidatív stressz csökkentésében, mely különösen fontos lehet a KAT és az APX enzimek indukciójának hiányában. 


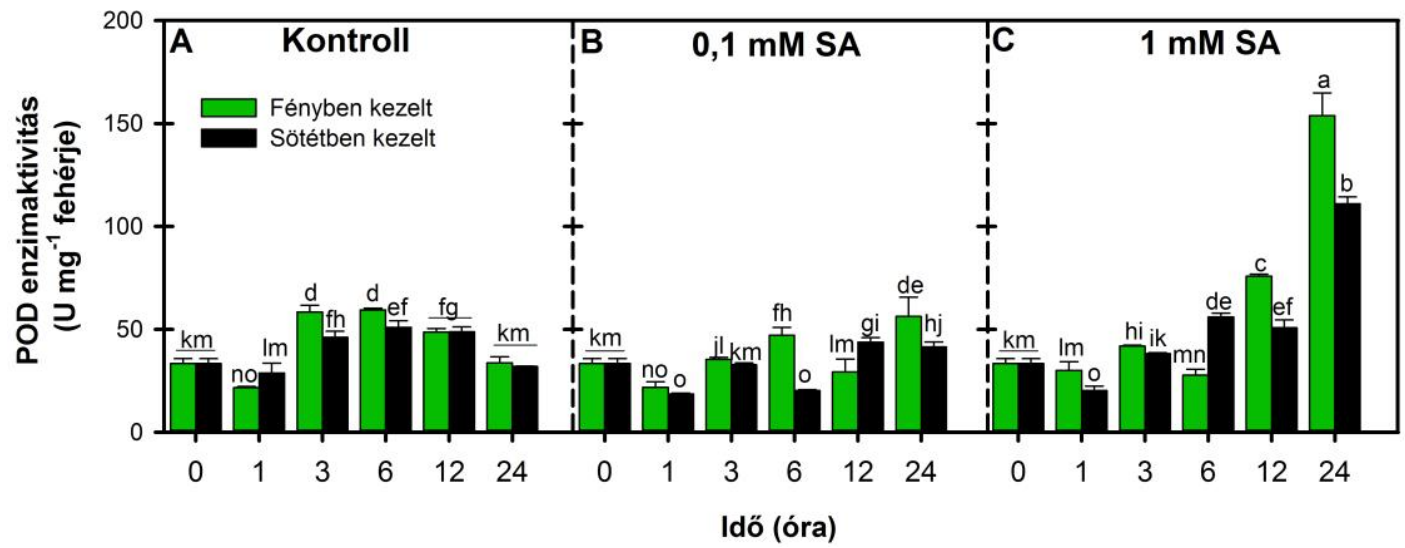

25. ábra: A POD aktivitásának változása ( $\mathrm{U} \mathrm{mg}^{-1}$ fehérje) VT paradicsom növények leveleiben kontroll körülmények között (A), valamint 24 óráig tartó $0,1 \mathrm{mM}$ (B) és $1 \mathrm{mM}$ (C) SA kezelést követően fényben ( $\square$ ) és sötétben ( $\square$ ) (Átlag $\pm \mathrm{SE}, \mathrm{n}=3, P \leq 0,05$ ).

\subsection{A különbözö SA kezelések által indukált oxidatív stressz vizsgálata normál fotoperióduson, valamint sötétben kezelt etilén receptor mutáns, Never-ripe paradicsom növények leveleiben}

\subsubsection{Az elektrolit kiáramlás és a $\mathrm{H}_{2} \mathrm{O}_{2}$ tartalom változása}

Kísérleteink további részében megvizsgáltuk, hogy az általunk már előzőekben leírt paraméterek milyen változásokat mutatnak a 24 óráig tartó normál fotoperióduson és sötétben történő exogén szubletális és letális SA kezelések hatására az $\mathrm{Nr}$ paradicsom növények leveleiben.

A levelek életképessége az EL alapján az alkalmazott SA koncentrációk közül az 1 mM SA kezelés hatására a VT növények esetében fényben, míg az $N r$ növényeknél sötétben csökkent szignifikánsan a kontrollhoz képest a 24. órára (26. ábra A, B, C).

24 óráig tartó exogén szubletális és letális SA kezelést követően szabad szemmel látható, hogy a szubletális SA kezelés nem okozott nektorikus szövetelhalásokat a VT és $\mathrm{Nr}$ levelekben egyik általunk vizsgált körülmény esetén sem (26. ábra D). Ezzel szemben, ha a növényeket normál fotoperióduson, $1 \mathrm{mM} \mathrm{SA-val} \mathrm{kezeltük,} \mathrm{a} \mathrm{két} \mathrm{genotípus} \mathrm{közül} \mathrm{csak} \mathrm{a} \mathrm{vad}$ típusú AC növények mutattak nagyobb mértékű szövetelhalásokat. Sötétben történő $1 \mathrm{mM} \mathrm{SA}$ kezelés hatására azonban érdekes módon az $N r$ növények levelein tapasztaltunk lézió megnagyobbodásokat és nagyobb mértékü nekrotikus szövetelhalásokat a vad típushoz képest (26. ábra D). 


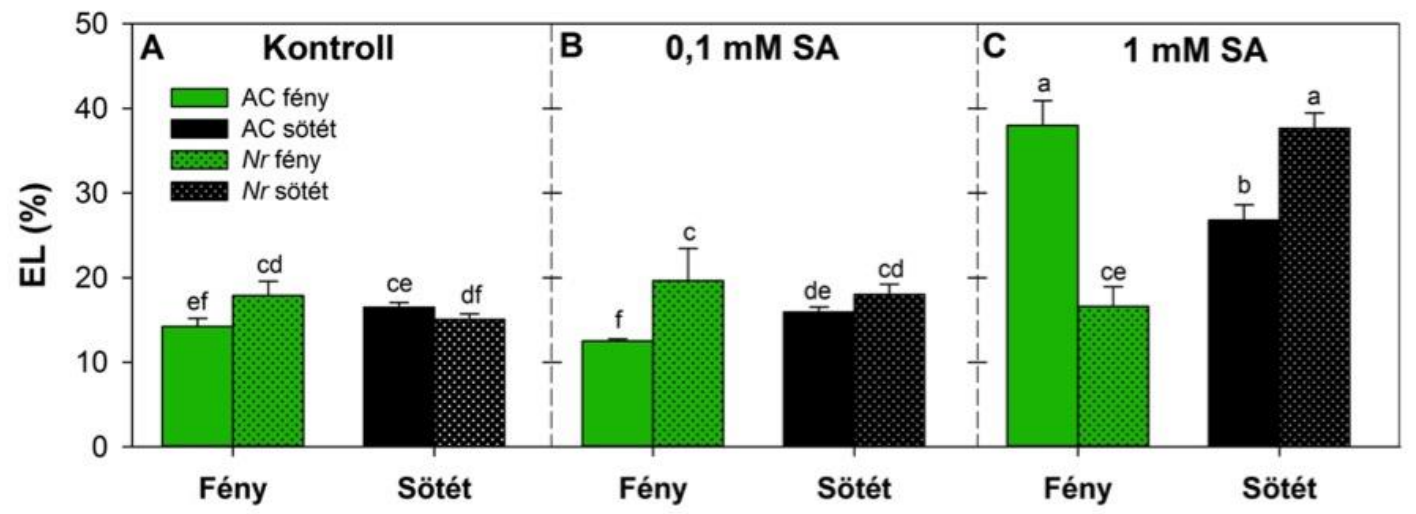

24. óra

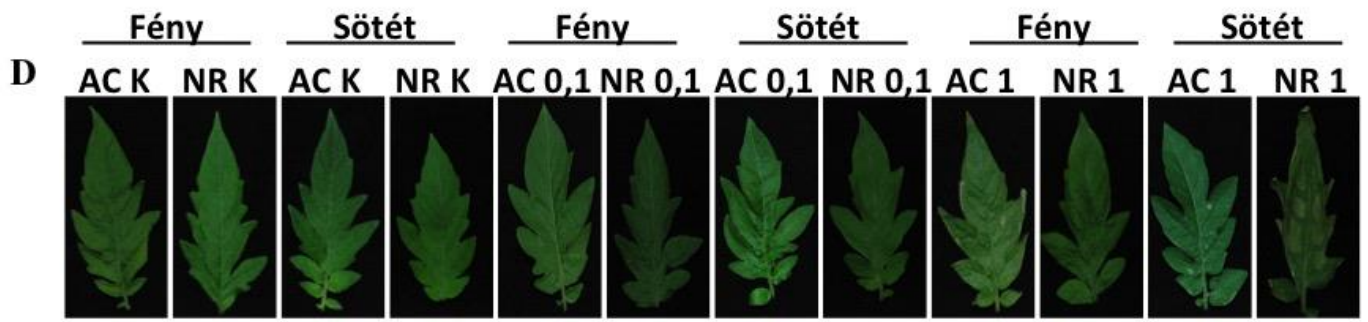

$24 \mathrm{~h}$

26. ábra: Az EL \%-os változása VT paradicsom növények leveleiben kontroll körülmények között (A), valamint 24 óráig tartó $0,1 \mathrm{mM}$ (B) és $1 \mathrm{mM}$ (C) SA kezelést követően fényben ( $\square$ ) és sötétben (ם) (Átlag $\pm \mathrm{SE}, \mathrm{n}=6, P \leq 0,05$ ). D: A vad típusú Ailsa Craig (AC) és $N r$ paradicsom növények leveleiben megfigyelhető változások kontroll körülmények között, valamint 24 óráig tartó $0,1 \mathrm{mM}$ és $1 \mathrm{mM} \mathrm{SA}$ kezelést követően, fényben és sötétben.

Mivel a léziók kialakulásának hátterében valószínüsíthetjük a ROS, ezek között a $\mathrm{H}_{2} \mathrm{O}_{2}$ felhalmozódását, a továbbiakban megvizsgáljuk az SA hatására a VT és az $N r$ levelekben kialakuló $\mathrm{H}_{2} \mathrm{O}_{2}$ tartalmakat és a $\mathrm{H}_{2} \mathrm{O}_{2}$ szintéziséhez és lebontásához hozzájáruló enzimek aktivitását a kétféle kezelés és megvilágítás mellett. Ez egyúttal választ adhat arra a kérdésre, hogy az ET jelátvitel hiánya hogyan befolyásolja az SA-indukált oxidatív stresszt normál fotoperióduson vagy sötétben.

Fényben a szubletális és letális $\mathrm{SA}$ kezelések szignifikánsan növelték a $\mathrm{H}_{2} \mathrm{O}_{2}$ mennyiségét mindkét genotípusban, bár ez az emelkedés az $N r$ növényekben a letális SA kezelés során szignifikánsan alacsonyabb volt a vad típushoz képest (27. ábra B, C). Sötétben történő SA kezelések hatására hasonló tendencia figyelhető meg, azonban $1 \mathrm{mM} \mathrm{SA}$ kezelés hatására az $\mathrm{Nr}$ növények leveleiben szignifikánsan magasabb $\mathrm{H}_{2} \mathrm{O}_{2}$ mennyiséget kaptunk a vad típushoz képest (27. ábra C). A DAB festést követően megállapítható, hogy a $\mathrm{H}_{2} \mathrm{O}_{2}$ felhalmozódása normál fotoperióduson a VT növények leveleinek, míg sötétben az $\mathrm{Nr}$ növények leveleinek marginális, parenchimatikus sejtjeiben mutatható ki a letális SA kezelést követően, mely eredmény korrelál a fotométeres méréseinkkel (27. ábra D). Ezek az eredmények azt mutatják, hogy habár mindkét genotípusban szignifikánsan emelkedett a $\mathrm{H}_{2} \mathrm{O}_{2}$ mennyisége, az ET receptor mutáns növények eltérően reagáltak a normál fotoperióduson, 
valamint a sötétben történő letális SA kezelésre. Ezért a továbbiakban fényt szeretnék deríteni, milyen folyamatok befolyásolhatják a letális SA okozta különbséget a VT és $\mathrm{Nr}$ paradicsom növények leveleiben, normál fotoperióduson és sötétben.
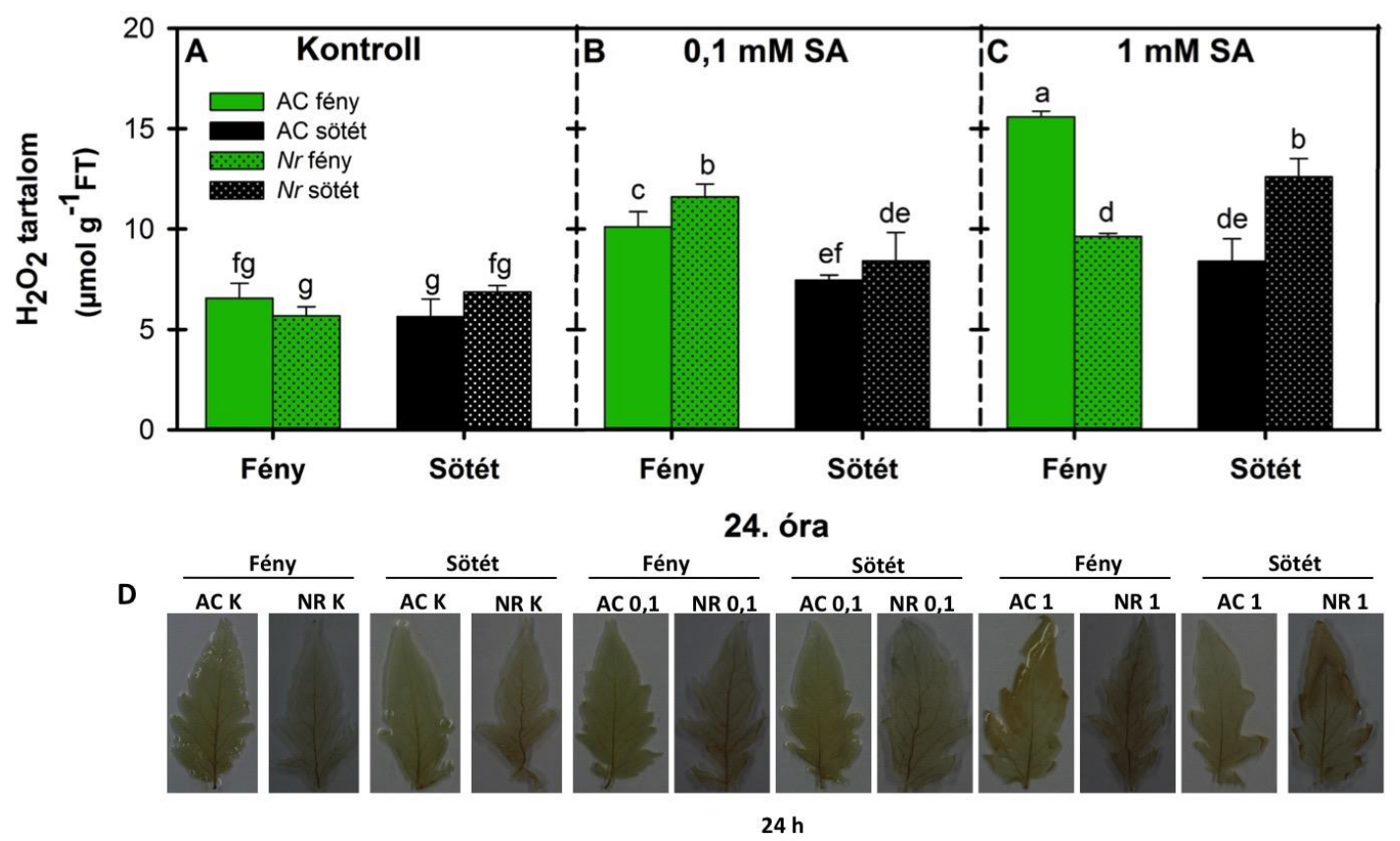

27. ábra: $\mathrm{A} \mathrm{H}_{2} \mathrm{O}_{2}$ tartalom változása ( $\mu$ mol $\mathrm{g}^{-1} \mathrm{FT}$ ) vad típusú (AC) és $N r$ paradicsom növények levelében kontroll körülmények között (A), valamint 24 óráig tartó $0,1 \mathrm{mM}$ (B) és $1 \mathrm{mM}$ (C) SA kezelést követően fényben ( $\square$ ) és sötétben ( $\square$ (Átlag $\pm \mathrm{SE}, \mathrm{n}=5, P \leq 0,05$ ). D: $\mathrm{A}_{2} \mathrm{O}_{2}$ termelödése $\mathrm{DAB}$ festés alapján AC és $N r$ paradicsom növények leveleiben kontroll körülmények között, valamint 24 óráig tartó $0,1 \mathrm{mM}$ és $1 \mathrm{mM}$ SA kezelést követően, fényben és sötétben. A barnás szín a $\mathrm{H}_{2} \mathrm{O}_{2}$ jelenlétét jelzi.

\subsubsection{Az endogén szabad, kötött és összes SA tartalom változásai VT és $\mathbf{N r}$ növények leveleiben}

Kontroll körülmények között és a 24 óráig tartó sötétkezelés hatására a szabad és kötött SA tartalom alacsonyabb koncentrációt mutatott az ET receptor mutáns, $N r$ növények leveleiben a VT-hez képest, azonban az össz SA tartalmakat megvizsgálva nem tapasztaltunk szignifikáns különbséget a két genotípus között (28. ábra A, D, G).

A teljes endogén SA tartalom 0,1 mM SA hatására 80 szorosára, míg 1 mM SA hatására 1200 szorosára emelkedett a VT növények leveleiben (28. ábra H, I). Habár az $\mathrm{Nr}$ növények leveleiben is szignifikánsan emelkedett az endogén SA koncentrációja mindkét exogén SA kezelés hatására, ez az emelkedés nem érte el a vad típusban kimutatható SA koncentrációkat (28. ábra H, I). 

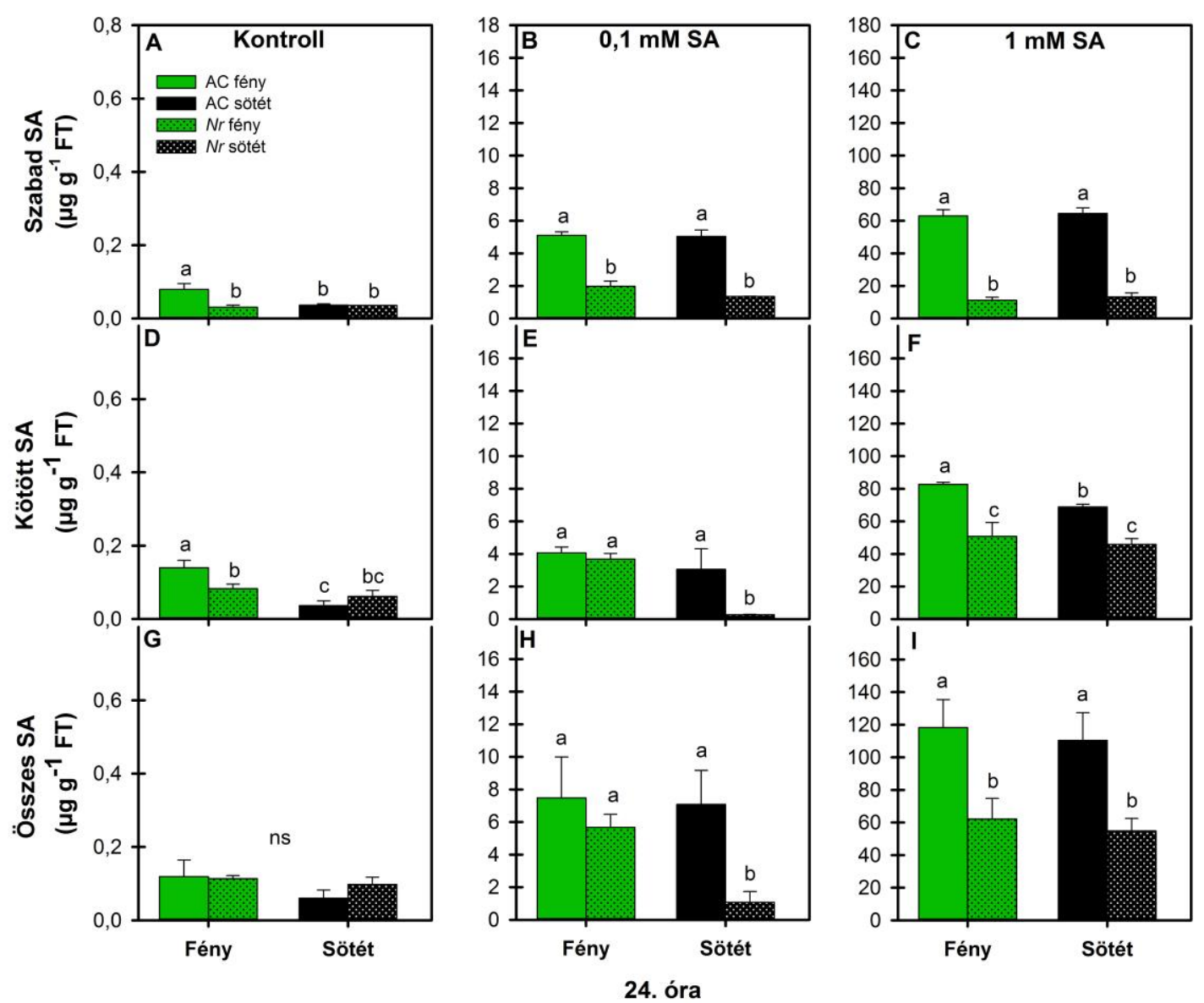

28. ábra: Az endogén szabad (A, B, C), kötött (D, E, F) és összes $(G, H, I)$ SA tartalom változása ( $\mu \mathrm{g} \mathrm{g}^{-1} \mathrm{FT}$ ) vad típusú (AC) és $N r$ paradicsom növények leveleiben kontroll körülmények között (A, D, G), valamint 24 óráig tartó $0,1 \mathrm{mM}(\mathrm{B}, \mathrm{E}, \mathrm{H})$ és $1 \mathrm{mM}(\mathrm{C}, \mathrm{F}, \mathrm{I})$ SA kezelést követően fényben ( $\square$ ) és sötétben ( $\square$ ) (Átlag $\pm \mathrm{SE}, \mathrm{n}=5, P \leq 0,05$ ).

\subsubsection{Az etilén termelődésének változása}

Mivel az ET és a PA-ok között kompetitív kapcsolat állhat fent, mert mindkét molekula bioszintézisének közös prekurzora a SAM, ezért megvizsgáltuk a két általunk kiválasztott genotípus ET termelődését a szubletális és letális SA kezeléseket követően, fényben és sötétben egyaránt.

Kontroll körülmények között, valamint 24 óráig tartó sötétkezelés során az $\mathrm{Nr}$ növények leveleiben szignifikánsan magasabb ET termelödést mutattunk ki a VT-ben mért adatokhoz képest (29. ábra A). Fényben történő 0,1 mM SA kezelés nem változtatta, míg az 1 mM SA kezelés nem szignifikáns módon, de csökkentette az ET termelődését a VT növények leveleiben. Ezzel szemben, ha a VT növényeket sötétben kezeltük, a 0,1 mM SA indukálta, míg az $1 \mathrm{mM}$ SA kismértékben csökkentette az ET termelödését a kontrollhoz képest (29. ábra A, B, C). A legmagasabb ET termelödést az $N r$ növények leveleiben a fényben történő $0,1 \mathrm{mM}$ SA kezelést követően tapasztaltuk. Ugyanakkor a sötétben történő SA 
kezelések az $N r$ növények ET termelödését kismértékben, de csökkentették, azonban még így is magasabb értéket tapasztaltunk a vad típushoz képest (29. ábra A, B, C).

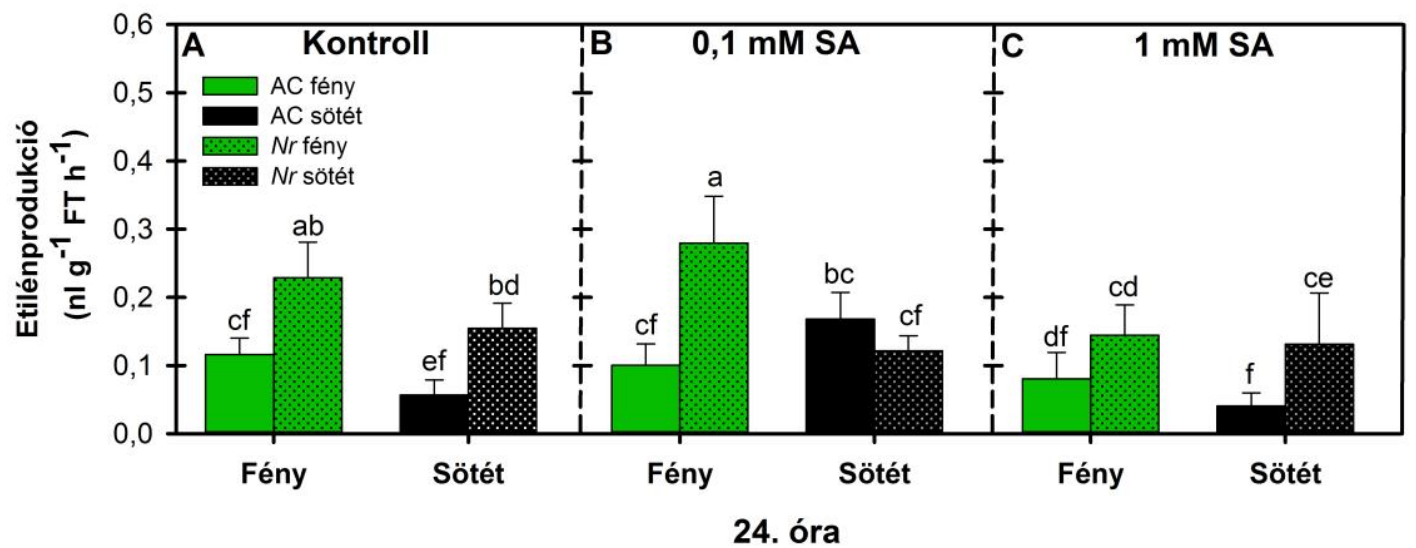

29. ábra: Az ET termelödés változása $\left(\mathrm{nl} \mathrm{g}^{-1} \mathrm{FT} \mathrm{h}^{-1}\right)$ vad típusú (AC) és $N r$ paradicsom növények leveleiben kontroll körülmények között (A), valamint 24 óráig tartó $0,1 \mathrm{mM}$ (B) és $1 \mathrm{mM}$ (C) SA kezelést követöen fényben ( $\square$ ) és sötétben ( $\mathbf{\square})$ (Átlag $\pm \mathrm{SE}, \mathrm{n}=6, P \leq 0,05$ ).

\subsubsection{A szabad poliaminok koncentrációjának változásai}

Mivel a szabad PA-ok bioszintézise a SAM-on keresztül szoros kapcsolatban áll az ET bioszintézisével, ezért kíváncsiak voltunk, hogyan változik a szabad PA-ok mennyisége vad típusú AC és ET receptor mutáns, $N r$ növényekben, a két általunk választott exogén SA kezelés hatására, fényben és sötétben.

Kontroll körülmények között, mindkét genotípus Put koncentrációja csökkent a 24 óráig tartó sötétkezelés hatására (30. ábra A). 0,1 mM SA kezelés nem befolyásolta szignifikáns a Put koncentrációját egyik genotípusban sem. Azonban 1 mM SA-val történő kezelés fényben kismértékben, míg sötétben szignifikánsan emelte a VT növények Put tartalmait 24 óra múlva. Ugyanakkor még a fényben az $1 \mathrm{mM}$ SA kezelés hatására nem mértünk szignifikáns változást, sötétben kismértékü emelkedést mutattunk ki az $N r$ növények Put koncentrációjában a kontrollhoz képest (30. ábra A, B, C).

Amíg az Spd koncentrációja kontroll körülmények között szignifikánsan emelkedett a VT növények leveleiben, addig az $N r$ növényekben nem mutatott szignifikáns változást a 24 óráig tartó sötétkezelés hatására (30. ábra D). A szubletális és letális SA kezelések a VT növények leveleiben mérhető Spd koncentrációban kismértékű emelkedést csak fényben okoztak, míg a sötétben történő kezelések nem befolyásolták szignfikánsan az Spd tartalmakat (30. ábra D, E, F). Ezzel szemben, ha az $N r$ növényeket fényben kezeltük, csak a 0,1 mM SA kezelés okozott szignifikáns emelkedést, míg a sötétben történő kezelések során az Spd tartalom már mindkét SA koncentrációnál szignifikánsan megemelkedett a kezeletlen kontrollhoz képest (30. ábra D, E, F). 
Az Spm koncentrációjában a legmarkánsabb emelkedést a fényben történő $1 \mathrm{mM}$ SA kezelés hatására tapasztaltunk a VT növények leveleiben, míg ha az $\mathrm{Nr}$ növényeket kezeltük szubletális vagy letális SA-val, koncentrációja nem mutatott szignifikáns változást egyik körülmény esetén sem (30. ábra G, H, I).

Összeségében elmondható, hogy a két általunk vizsgált genotípus közül a VT növények levelei tartalmaztak nagyobb szabad PA-koncentrációkat az $N r$ növényekhez képest, minden kezelési körülmény esetén (30. ábra). Továbbá az, hogy a szabad PA-ok koncentrációjában kapott eredmények ellentétesek az ET termelödésében mért adatokhoz képest, ahol az $\mathrm{Nr}$ növények mutattak szignifikánsan magasabb értékeket minden kezelési körülmény mellett (29. ábra), ezzel mutatva, hogy az $N r$ növények leveleiben az exogén SA kezeléseket követően nem a PA-ok bioszintézisének irányába használódhat fel a SAM. Különösen jelentős a különbség a VT és az $N r$ között az Spm felhalmozódásában, ami két lépésben kapja a dekarboxilált SAM szénláncát, míg az Spd tartalom kiegyensúlyozott marad a két genotípusban az SA kezelések mellett.

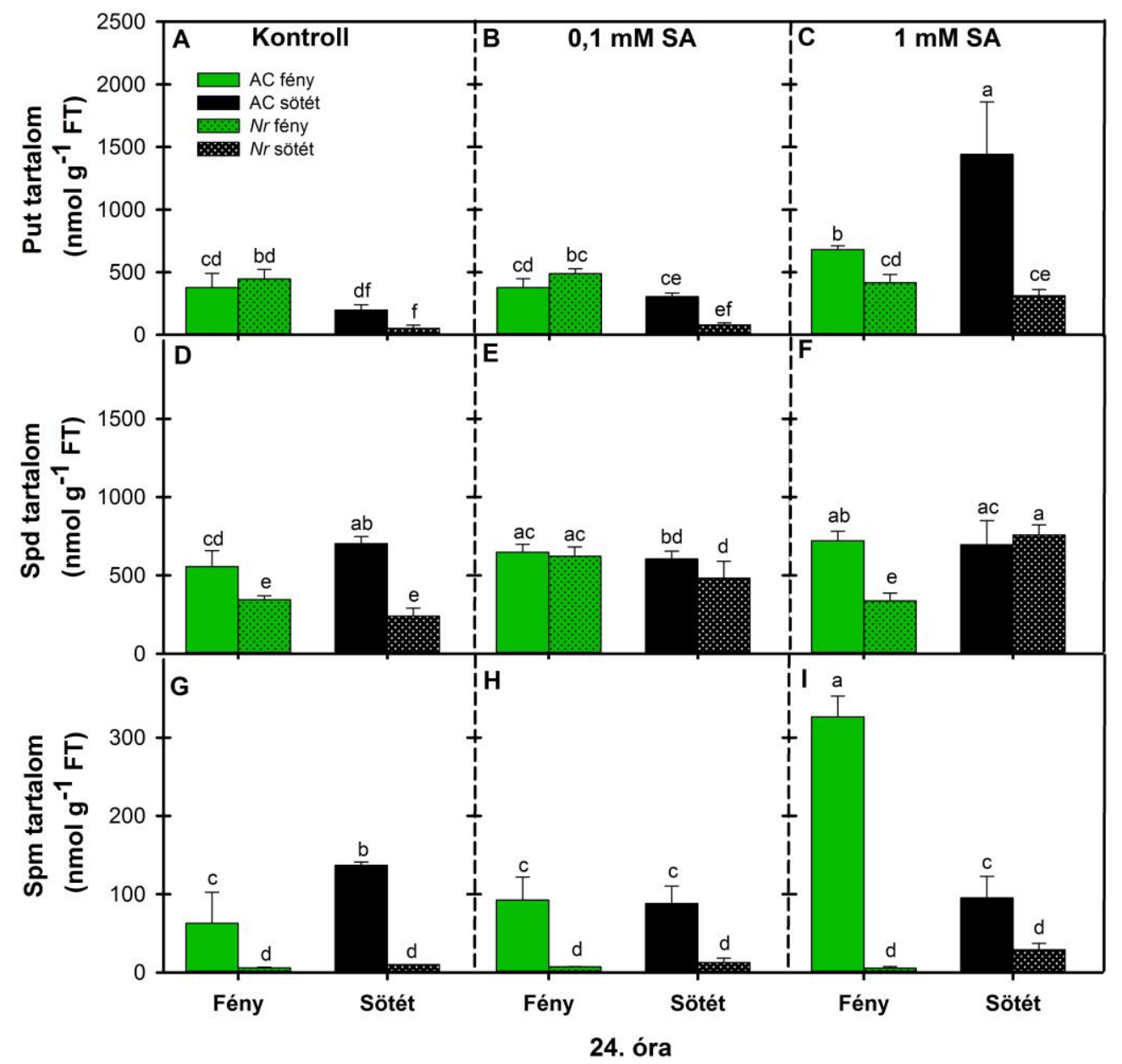

30. ábra: A szabad PA-ok [Put (A, B, C); Spd (D, E, F); Spm (G, H, I)] mennyiségének változásai (nmol g ${ }^{-1} \mathrm{FT}$ ) vad típusú (AC) és $N r$ paradicsom növények leveleiben kontroll körülmények között (A, D, G), valamint 24 óráig tartó 0,1 $\mathrm{mM}(\mathrm{B}, \mathrm{E}, \mathrm{H})$ és $1 \mathrm{mM}(\mathrm{C}, \mathrm{F}, \mathrm{I})$ SA kezelést követően fényben $(\square)$ és sötétben ( $\square)$ (Átlag $\pm \mathrm{SE}, \mathrm{n}=5, P \leq 0,05$ ). 


\subsubsection{A PA-ok bioszintézisében szerepet játszó enzimeket kódoló gének expresszójának változásai}

A következőkben arra a kérdésre kerestük a választ, hogy hogyan befolyásolja az ET jelátvitel hiánya a PA-ok bioszintézisében szerepet játszó enzimeket kódoló gének expresszióját, 24 órás szubletális és letális SA kezelés során, normál fotoperióduson és sötétben.

Kontroll körülmények között nem tapasztaltunk szignifikáns különbséget a VT és $\mathrm{Nr}$ növények leveleiben mérhető $S I A D C$ és $S I O D C$ gének expressziójában. 24 óráig tartó sötétkezelés hatására a Put bioszintézisében szerepet játszó SlADC és SIODC gének expressziója gátlódott mindkét általunk vizsgált genotípusban, mely eredmény azt mutathatja, hogy mindkét gén expressziója, az ET jelátvitelétől független módon a sötétkezelés hatására gátlódik (31. ábra A, D).

Vad típusban a normál fotoperióduson csak az SlADC gén expressziójában tapasztaltunk szignifikáns emelkedést, míg az SlODC gén repressziót mutatott mindkét SA kezelés hatására. Ezzel szemben a megvilágított $N r$ növényekben csak a $0,1 \mathrm{mM}$ SA kezelés indukálta az $S I A D C$ és $S I O D C$ gének expresszióját, míg a letális SA kezelés gátolta azokat (31. ábra B, C, E, F). Sötétben, mindkét gén expressziója az SA koncentrációjától függő módon indukálódott a VT levelekben, míg az $\mathrm{Nr}$ levelekben nem tapasztaltunk szignifikáns változást a kontrollhoz képest (31. ábra).

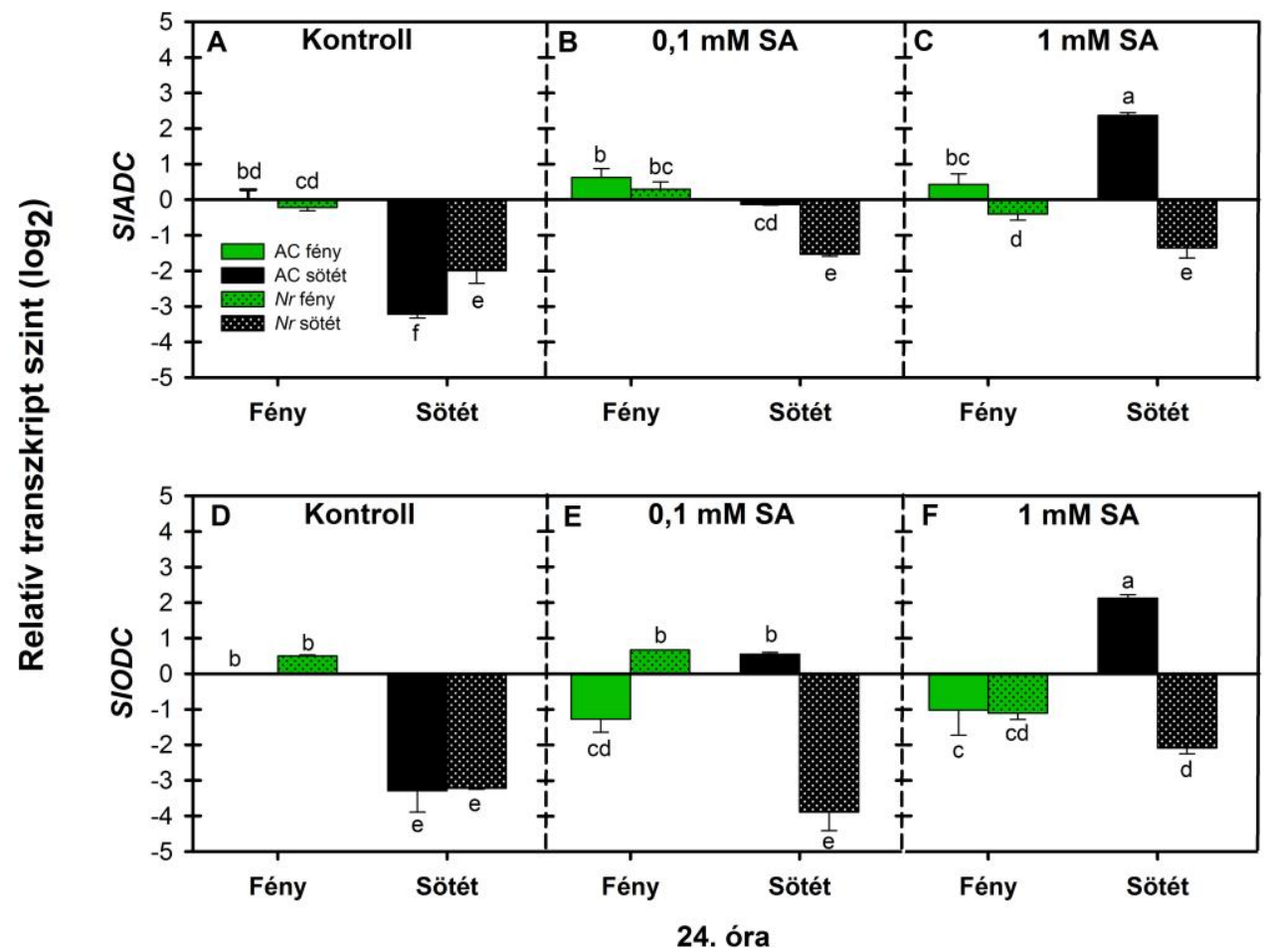

31. ábra: A PA-ok bioszintézisében szerepet játszó enzimeket kódoló gének [SlADC (A, B, C); SlODC (D, E, F)] expressziójának változása vad típusú (AC) és $N r$ paradicsom növények leveleiben kontroll körülmények között (A, D), valamint 24 óráig tartó $0,1 \mathrm{mM}(\mathrm{B}, \mathrm{E})$ és $1 \mathrm{mM}(\mathrm{C}, \mathrm{F}) \mathrm{SA}$ kezelést követően fényben ( $\square$ ) és sötétben ( $\square$ ) (Átlag $\pm \mathrm{SE}, \mathrm{n}=5, P \leq 0,05$ ). 
A következőkben megvizsgáltuk a dcSAM bioszintézisében kulcsfontosságú SISAMDC és az Spd és Spm bioszintézisében szerepet játszó SISPDS és SISPMS gének expresszióját a két általunk kiválasztott genotípusban, a 24 óráig tartó exogén szubletális és letális SA kezelés hatására, fényben és sötétben.

Kontroll körülmények között az $N r$ növényekben csökkent SISAMDC és SISPMS relatív transzkript szinteket mértünk a VT-hez képest. A 24 óráig tartó sötétkezelés hatására az SISAMDC és SISPDS gének expressziója indukciót, míg az SISPMS gén expressziója repressziót mutatott a VT növények leveleiben. Ezzel szemben a sötétben tartott $\mathrm{Nr}$ növények leveleiben mindhárom általunk vizsgált bioszintetikus gén represszálódott (32. ábra $A, D, G$ ).

Normál fotoperióduson, a VT növények leveleiben csak az SISPDS gén expressziója csökkent, míg az $N r$ növényekben csak ez a gén mutatott indukciót a szubletális SA kezelés hatására. Sötétben azonban a dcSAM, az Spd és Spm bioszintézisében szerepet játszó enzimeket kódoló gének relatív transzkript szintjei egyik genotípus esetén sem mutattak változást a kontrollhoz képest (32. ábra B, E, H).

1 mM SA kezelés hatására az SISAMDC, SISPDS és SISPMS gének expressziói szignifikáns indukciót mutattak a megvilágított VT levelekben, azonban a mutáns növényekben az SISPDS és SISPMS gén expressziója nem adott szignifikáns változást a kontrollhoz képest (32. ábra C, F, I). Ha a VT növényeket sötétben kezeltük nem tapasztaltunk szignifikáns eltérést, míg az $N r$ növényeknél kismértékü, nem szignifikáns indukciót mértünk az SISAMDC expressziójában a kontrollhoz képest (32. ábra C, F, I). 

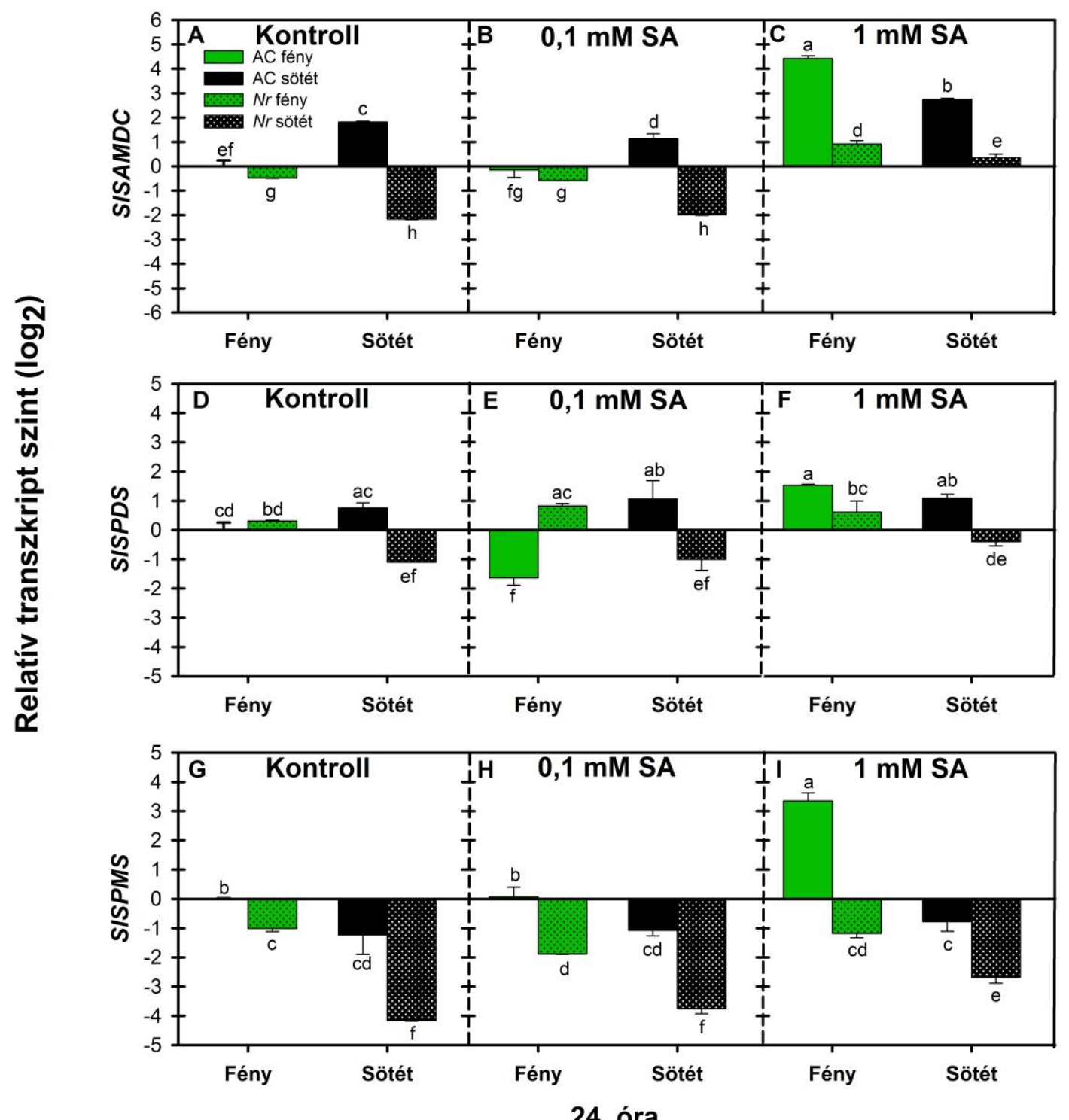

32. ábra: A PA-ok bioszintézisében szerepet játszó gének [SISAMDC (A, B, C); SlSPDS (D, E, F); $\operatorname{SlSPMS}(\mathrm{G}, \mathrm{H}, \mathrm{I})$ ] expressziójának változása vad típusú (AC) és $N r$ paradicsom növények leveleiben kontroll körülmények között (A, D, G), valamint 24 óráig tartó $0,1 \mathrm{mM}$ (B, E, H) és $1 \mathrm{mM}(\mathrm{C}, \mathrm{F}, \mathrm{I}) \mathrm{SA}$ kezelést követően fényben ( $\square$ ) és sötétben ( $\square$ ) (Átlag $\pm \mathrm{SE}, \mathrm{n}=5, P \leq 0,05$ ).

\subsubsection{A PA-ok lebontásában szerepet játszó enzimek aktivitásának és gén expressziójának változásai}

A következőkben megvizsgáltuk, hogyan változik a 24 óráig tartó exogén szubletális és letális SA kezelés, normál fotoperióduson és sötétben történő alkalmazása során a PA-ok lebontásában kulcsfontosságú enzimek aktivitása és génjeik expressziója a VT-ben és az ET receptor mutáns paradicsom növényekben, mivel a lebontást végző enzimek aktivitása kulcsfontosságú az oxidatív robbanás, ezáltal pedig a PCD indukciójában.

A VT növényekben a 0,1 mM SA kezelés kismértékben csökkentette, míg az 1 mM SA kezelés növelte a Put katabolizmusában szerepet játszó DAO aktivitását, mindkét általunk 
vizsgált körülmény esetén (33. ábra $\mathrm{A}, \mathrm{B}, \mathrm{C}$ ). Ezzel szemben az $\mathrm{Nr}$ növényekben normál fotoperióduson mindkét SA kezelés, míg sötétben a letális SA koncentráció okozott indukciót a DAO aktivitásában (33. ábra A, B, C).

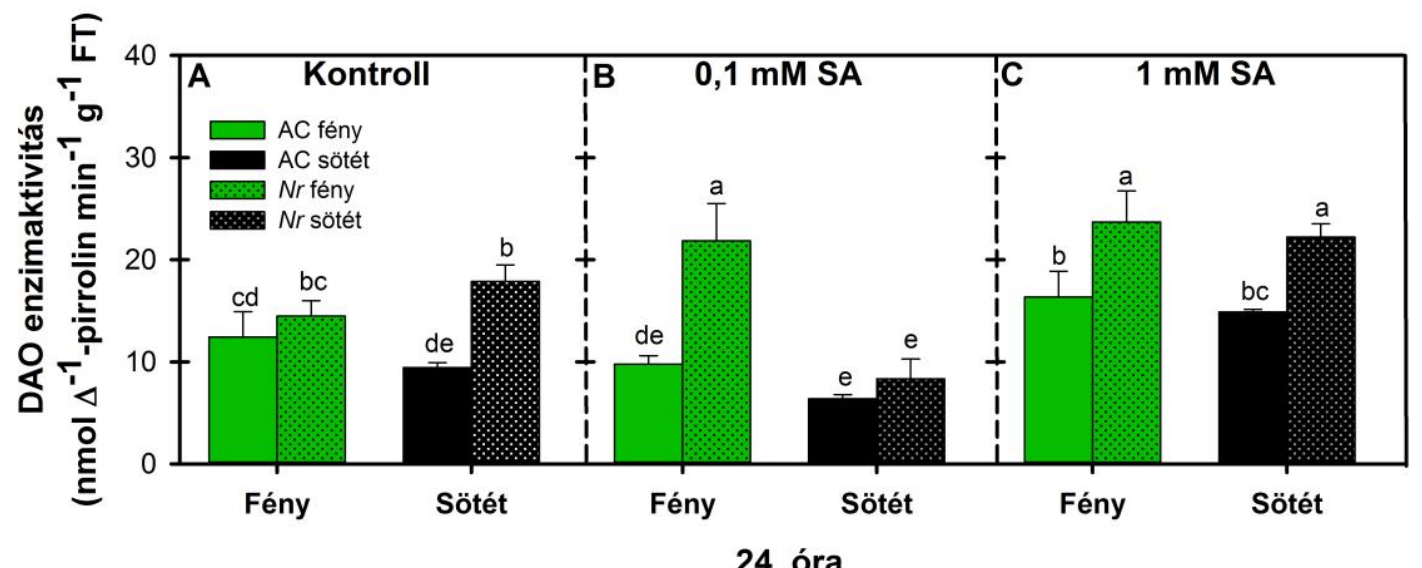

33. ábra: A DAO aktivitásának változása (nmol $\Delta^{1}$-pirrolin $\min ^{-1} \mathrm{~g}^{-1} \mathrm{FT}$ ) vad típusú (AC) és $N r$ paradicsom növények leveleiben kontroll körülmények között (A), valamint 24 óráig tartó $0,1 \mathrm{mM}(\mathrm{B})$ és $1 \mathrm{mM}(\mathrm{C}) \mathrm{SA}$ kezelést követően fényben $(\square)$ és sötétben (ם) (Átlag $\pm \mathrm{SE}, \mathrm{n}=5, P \leq 0,05$ ).

Kontroll körülmények során az általunk vizsgált SIDAO1 és SIDAO2 gének relatív transzkript szintjei nem mutattak szignifikáns különbséget a vad típus és a mutáns között, azonban 24 óráig tartó sötétkezelés hatására azok jelentősen alulregulálódtak (34. ábra A, D). Normál fotoperióduson a VT növényekben csökkent, míg az $N r$ növényekben szignifikánsan nött mindkét gén expressziója az emelkedő SA koncentrációk hatására (34. ábra B, C, E, F). Ezzel szemben a sötétben kezelt VT és $N r$ növényekben mindkét gén relatív transzkript szintje, mindkét SA kezelés hatására növekedett (34. ábra B, C, E, F). 


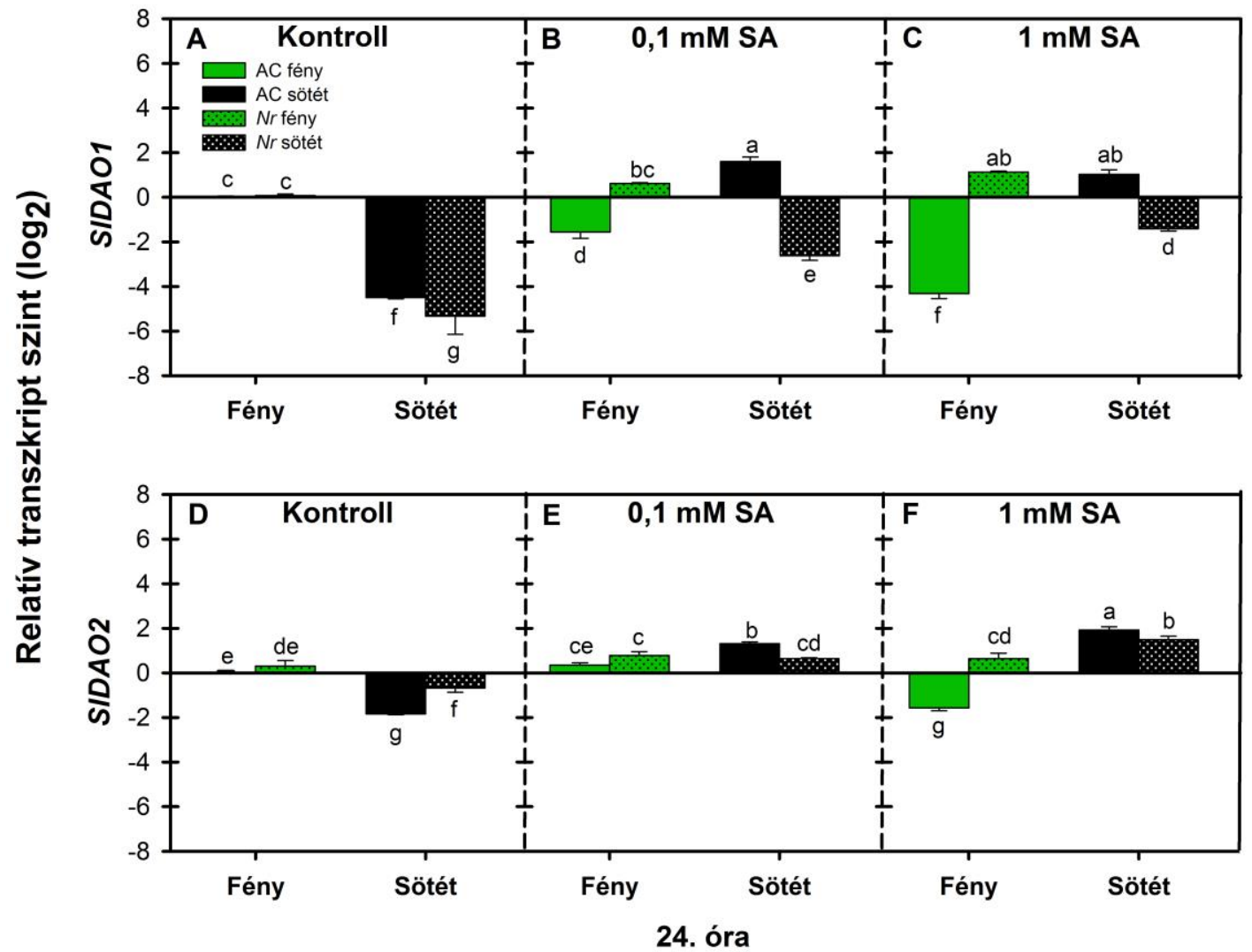

34. ábra: A PA-ok katabolizmusában szerepet játszó DAO izoenzimeket kódoló gének [SIDAO1 (A, B, C); SIDAO2 (D, E, F)] expressziójának változása vad típusú (AC) és $N r$ paradicsom növények leveleiben kontroll körülmények között $(\mathrm{A}, \mathrm{D})$, valamint 24 óráig tartó $0,1 \mathrm{mM}(\mathrm{B}, \mathrm{E})$ és $1 \mathrm{mM}(\mathrm{C}, \mathrm{F})$ SA kezelést követöen fényben ( $\square$ ) és sötétben ( $\square$ ) (Átlag $\pm \mathrm{SE}, \mathrm{n}=5, P \leq 0,05$ ).

Az Spd és Spm lebontásában szerepet játszó PAO aktivitása a normál fotoperióduson kezelt VT növényekben egyik SA koncentráció hatására sem mutatott szignifikáns változást, míg sötétben az aktivitása csak a letális SA kezelés hatására indukálódott (35. ábra A, B, C). Ezzel szemben a normál fotoperióduson tartott $N r$ növények PAO aktivitása szignifikánsan magasabb volt kontroll és 0,1 mM SA kezelés esetében is, mely aktivitás a letális SA hatására szignifikánsan csökkent. 24 óráig tartó sötétkezelés hatására azonban ellentétesen, az SA növekvö koncentrációjától függő módon tapasztaltunk szignifikáns aktivitásemelkedést (35. ábra A, B, C). 


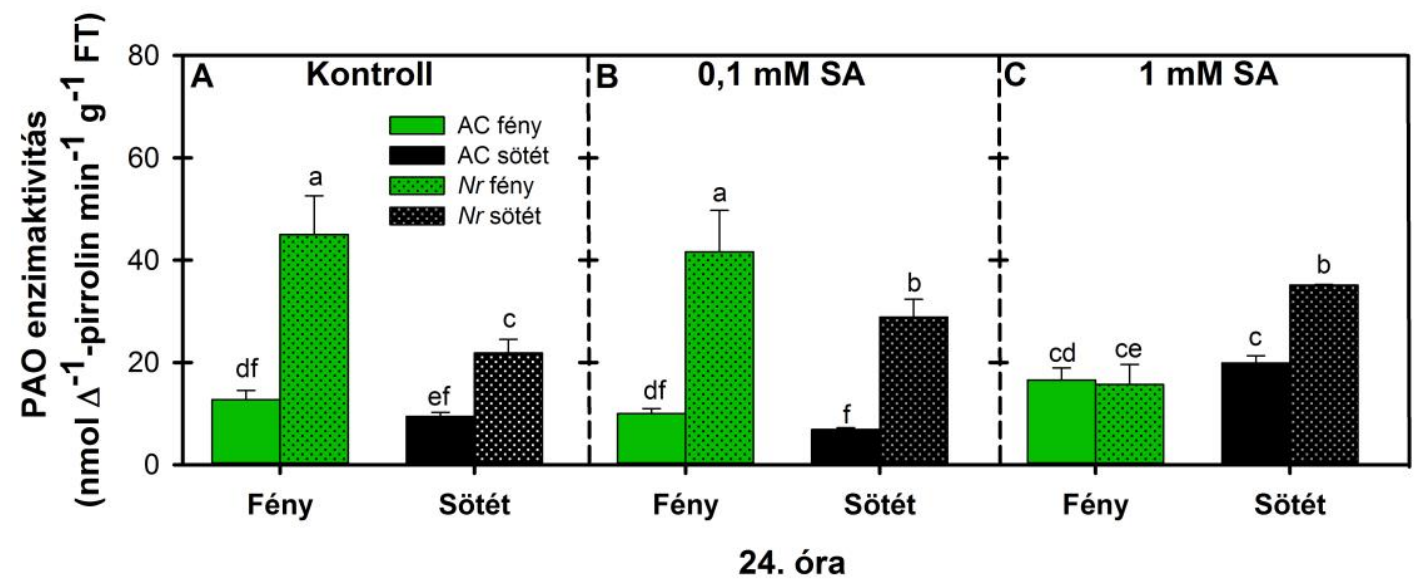

35. ábra: A PAO aktivitásának változása (nmol $\Delta^{1}$-pirrolin $\min ^{-1} \mathrm{~g}^{-1} \mathrm{FT}$ ) vad típusú (AC) és $N r$ paradicsom növények levelében kontroll körülmények között (A), valamint 24 óráig tartó $0,1 \mathrm{mM}$ (B) és $1 \mathrm{mM}(\mathrm{C}) \mathrm{SA}$ kezelést követően fényben ( $\square$ ) és sötétben ( $\square)$ (Átlag $\pm \mathrm{SE}, \mathrm{n}=5, P \leq 0,05$ ).

Normál fotoperióduson kezelt VT növények leveleiben a PAO izoenzimeket kódoló SIPAO1 és SIPAO2 gének expressziói nem mutattak szignifikáns különbséget, míg a mutáns növényekben mindkét SA kezelés hatására szignifikáns indukciót csak az SlPAOl gén expressziójában tapasztaltunk (36. ábra B, C, E, F).

24 óráig tartó sötétkezelés, kontroll körülmények között, a DAO izoenzimeket kódoló génekhez hasonlóan represszálta az SIPAO1 és SIPAO2 géneket mindkét genotípusban (36. ábra A, D). Sötétben történő szubletális és letális SA kezelések szignifikánsan csak az SlPAO1 gén expresszióját indukálták a mutáns növényekben (36. ábra $\mathrm{B}, \mathrm{C}$ ), míg az SlPAO2 gén expressziója represszálódott mindkét általunk vizsgált genotípusban (36. ábra E, F).

A kapott eredmények alapján megállapítható, hogy a sötétben történő $\mathrm{H}_{2} \mathrm{O}_{2}$ felhalmozódásának hátterében a megemelkedett DAO és PAO enzimek aktivitása is állhat, ugyanis a PA-ok lebontása során melléktermékként $\mathrm{H}_{2} \mathrm{O}_{2}$ keletkezik. Ugyanakkor a $\mathrm{H}_{2} \mathrm{O}_{2}$ mennyiségét a különböző antioxidáns enzimek aktivitásai is befolyásolhatják, ezért a továbbiakban megvizsgáltuk, hogyan változnak ezen enzimek aktivitásai és az őket kódoló gének expressziói a két genotípusban. 

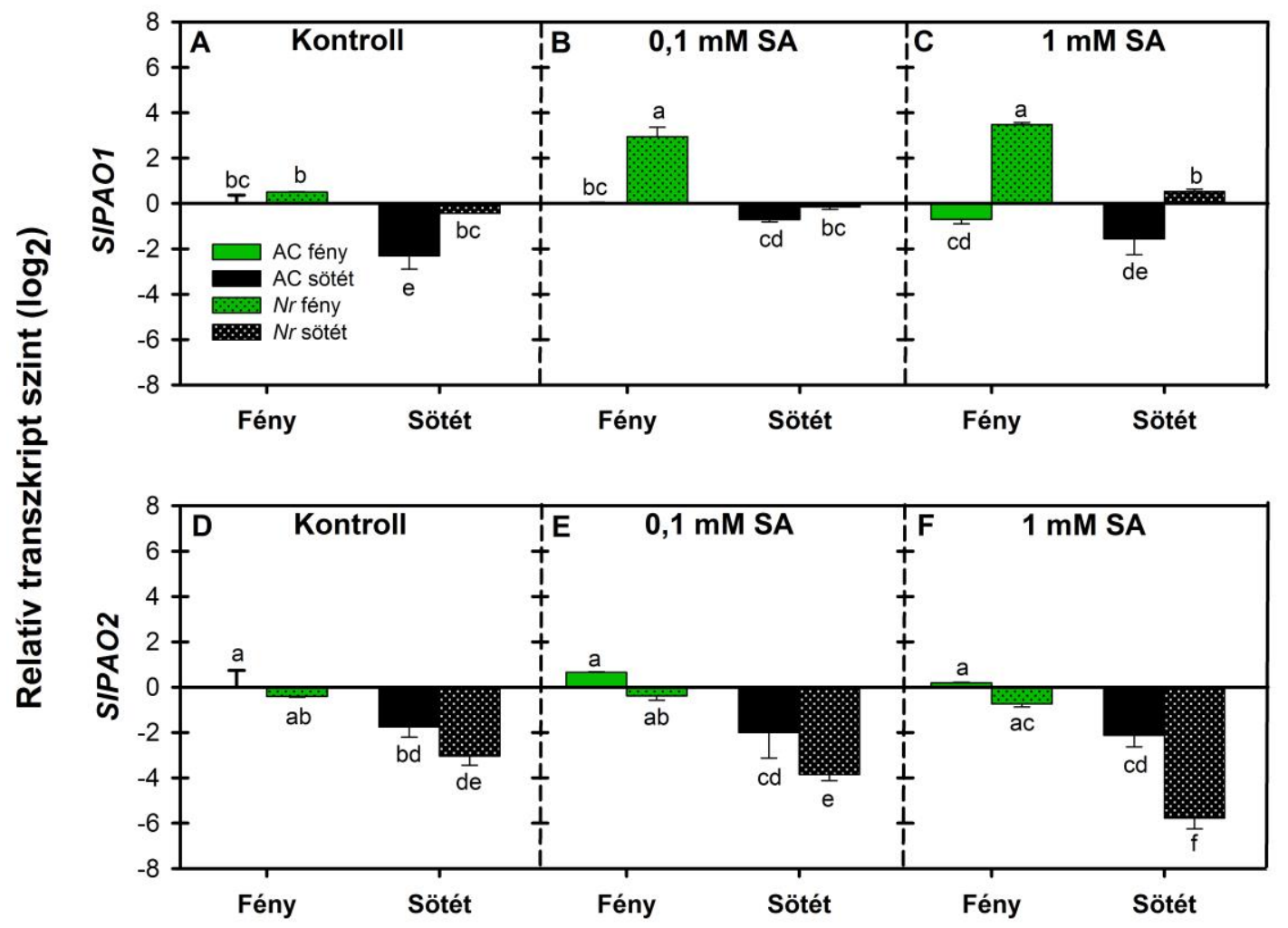

24. óra

36. ábra: A PA-ok katabolizmusában szerepet játszó PAO izoenzimeket kódoló gének [SlPAO1 (A, B, C); SlPAO2 (D, E, F)] expressziójának változása vad típusú (AC) és $N r$ paradicsom növények leveleiben kontroll körülmények között (A, D), valamint 24 óráig tartó $0,1 \mathrm{mM}(\mathrm{B}, \mathrm{E})$ és $1 \mathrm{mM}(\mathrm{C}, \mathrm{F})$ SA kezelést követően fényben $(\square)$ és sötétben ( $\square$ ) (Átlag $\pm \mathrm{SE}, \mathrm{n}=5, P \leq 0,05$ ).

\subsubsection{A szuperoxid-dizmutáz enzim aktivitása és az izoenzimeket kódoló gének expressziója}

Az SA indukálta $\mathrm{H}_{2} \mathrm{O}_{2}$ termelődése nemcsak a PA-ok lebontása, hanem különböző antioxidáns enzimek által is szabályozott. Kontroll körülmények között, 24 óráig tartó sötétkezelés nem befolyásolta szignifikánsan a SOD aktivitását a VT és $N r$ növények leveleiben (37. ábra A). VT-ben, normál fotoperióduson történő $0,1 \mathrm{mM}$ SA kezelés csökkentette, míg az $1 \mathrm{mM} \mathrm{SA}$ kezelés növelte a SOD enzim aktivitását. Azonban az $N r$ növényekben nem tapasztaltunk szignifikáns aktivitásváltozást egyik SA koncentrációnál sem (37. ábra B, C). Sötétben, míg a letális SA kezelés nem változtatta meg a VT növények SOD aktivitását, addig az $\mathrm{Nr}$ növények leveleiben szignifikánsan nagyobb aktivitást kaptunk a kontrollhoz képest (37. ábra C), mely aktivitásváltozások jól korreláltak a $\mathrm{H}_{2} \mathrm{O}_{2}$ koncentrációjában mért változásokkal (27. ábra).

Natív PAGE-el történő elválasztás után megvizsgáltuk a különböző SOD izoenzimek aktivitásának változását is. Az elválasztás során 5 izoenzimet tudtunk elkülöníteni a VT és $\mathrm{Nr}$ növények leveleiben, habár az első izoenzim alig volt észrevehető (37. ábra D). Az első jelet MnSOD-ként azonosítottuk, mivel ez nem volt gátolható $\mathrm{KCN}$ vagy $\mathrm{H}_{2} \mathrm{O}_{2}$ kezeléssel. A másodikat FeSOD-ként azonosítottuk, mivel a $\mathrm{H}_{2} \mathrm{O}_{2}$ gátolta az aktivitását. A harmadikat, 
negyediket és ötödiket pedig $\mathrm{Cu} / \mathrm{ZnSOD}$-ként azonosítottuk, mivel aktivitásuk a KCN és a $\mathrm{H}_{2} \mathrm{O}_{2}$ kezelés hatására gátolható volt. A Cu/ZnSOD volt a fő izoforma a VT és $N r$ növények leveleiben, mely izoenzimek változása pozitív korrelációt mutatott a fotométeres mérésekkel (37. ábra A, B, C). Sötétben, az 1 mM SA-val kezelt ET receptor mutáns növények leveleiben volt kimutatható nagyobb aktivitást a SOD izoformák alapján, különösen a mitokondriális MnSOD esetén (37. ábra D), mely magyarázatul szolgálhat a sötétben történő kezelés hatására megemelkedett $\mathrm{H}_{2} \mathrm{O}_{2}$ mennyiségére.
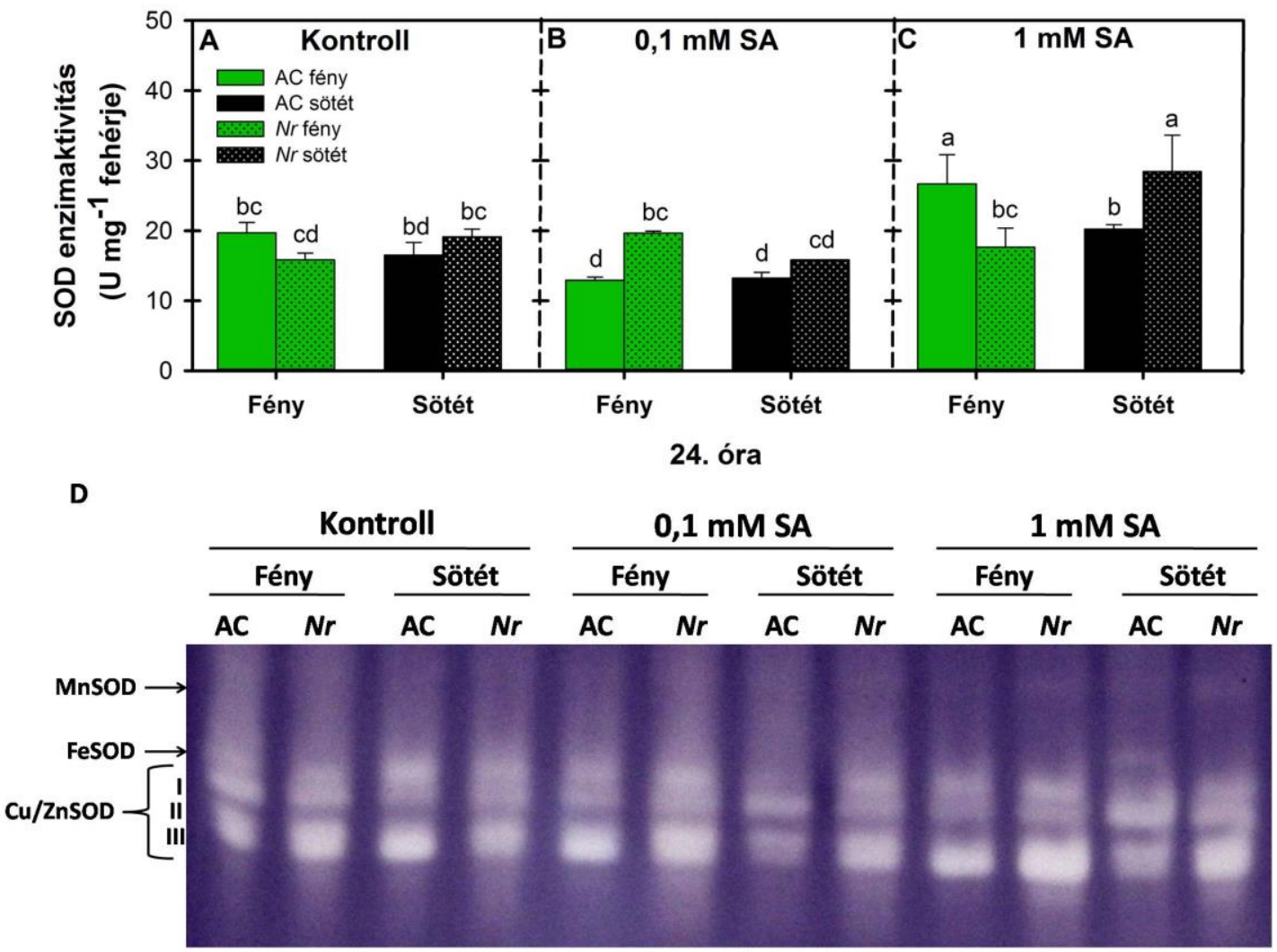

24. óra

37. ábra: A SOD enzim aktivitásának változása (U mg-1 fehérje) vad típusú (AC) és $N r$ paradicsom növények leveleiben kontroll körülmények között (A), valamint 24 óráig tartó $0,1 \mathrm{mM}$ (B) és $1 \mathrm{mM}(\mathrm{C})$ SA kezelést követően fénybe ( $\square$ ) és sötétben (ם) (Átlag $\pm \mathrm{SE}, \mathrm{n}=5, P \leq 0,05$ ). A SOD-izoenzimek változása natív gélben, szelektív festést követően (D). Az itt látható gélkép egy reprezentatív kísérlet eredménye, melyet három alkalommal ismételtünk meg.

A SOD izoenzimeket kódoló gének expressziójának vizsgálata során a kontroll esetben nem tapasztaltunk szignifikáns különbséget a VT és $N r$ növények között a fényben. 24 óráig tartó sötétkezelés azonban eltérő módon befolyásolta a három izoenzimet kódoló gén relatív transzkript szintjét. Amíg a VT növényekben az SIMnSOD transzkript szintje csökkent, valamint az SlFeSOD-é nem változott és az SlCu/ZnSOD szintje emelkedett, addig az $\mathrm{Nr}$ növényekben az SIMnSOD és SlFeSOD gének expressziója csökkent a normál fotoperióduson kezelt növényekhez képest (38. ábra A, D, G). Normál fotoperióduson a szubletális SA kezelés nem okozott szignifikáns változást a VT és $N r$ növények leveleiben a kontrollhoz képest, 
kivéve az $N r$ növényekben mérhető SlFeSOD transzkript szintjét, ahol szignifikáns indukciót figyelhettünk meg. Sötétben a VT növényekben a $0,1 \mathrm{mM}$ SA kezelés szignifikánsan az SlFeSOD és $S l C u / Z n S O D$ expresszióját csökkentette, míg az $\mathrm{Nr}$ növényekben nem kaptunk szignifikáns különbséget (38. ábra B, E, H).

$1 \mathrm{mM}$ SA a normál fotoperióduson kezelt VT növényekben szignifikánsan növelte az SIMnSOD és $S l C u / Z n S O D$ relatív transzkript szintjét, miközben az általunk vizsgált gének transzkript szintjei kontrollhoz közeli értékeket mutattak az $N r$ növényekben (37. ábra $\mathrm{C}$, I). Sötétben történő $1 \mathrm{mM}$ SA kezelés hatására azonban az $\mathrm{Nr}$ növények $S l C u / Z n S O D$ expressziója mutatott nagyobb mértékü indukciót a vad típushoz képest (38. ábra F, I).

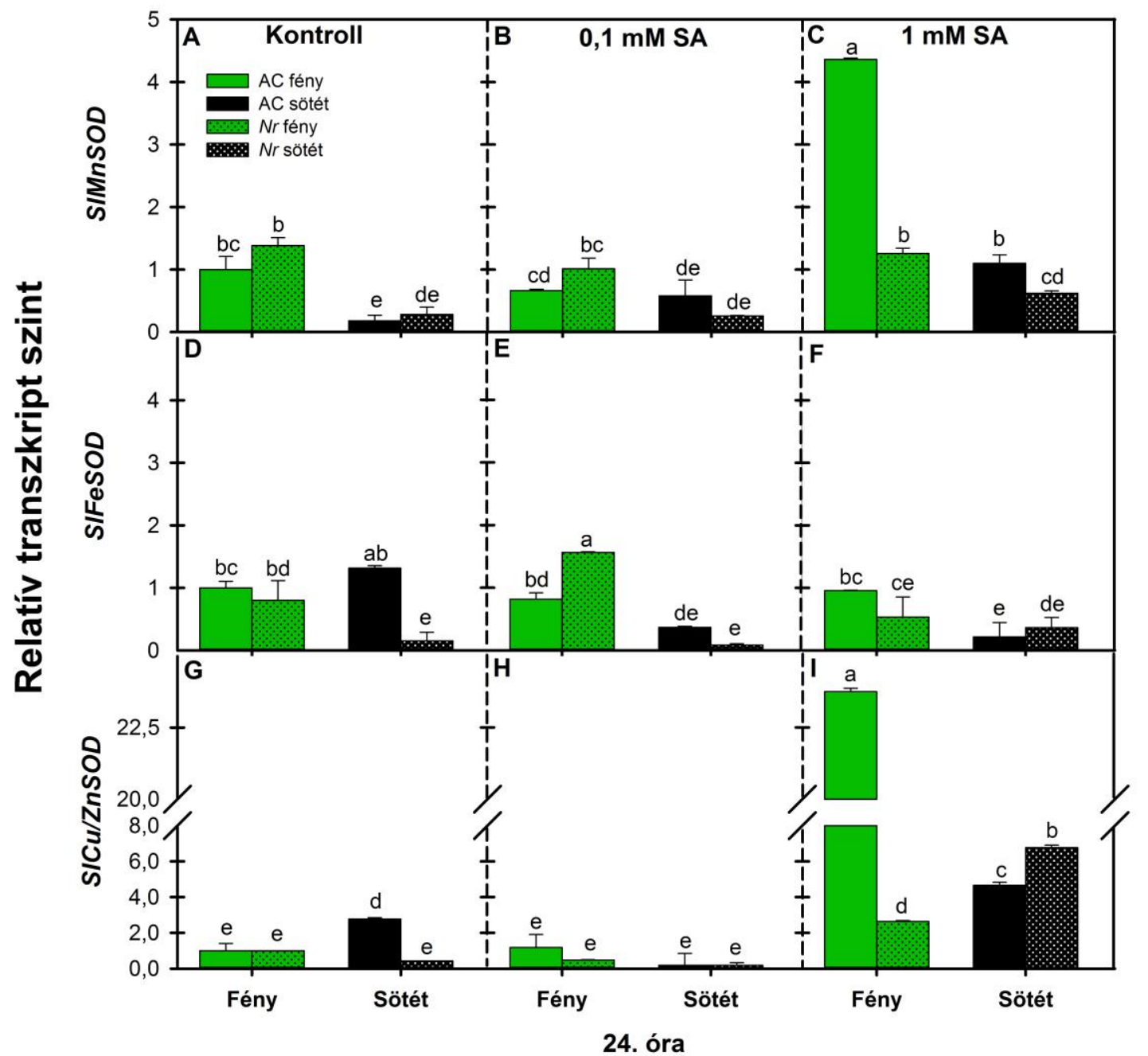

38. ábra: A SOD izoenzimeket kódoló gének [SIMnSOD (A,B,C); SlFeSOD (D,E,F); SlCu/ZnSOD $(\mathrm{G}, \mathrm{H}, \mathrm{I})]$ expressziójának változása vad típusú (AC) és $N r$ paradicsom növények leveleiben kontroll körülmények között (A,D,G), valamint 24 óráig tartó $0,1 \mathrm{mM}(\mathrm{B}, \mathrm{E}, \mathrm{H})$ és $1 \mathrm{mM}(\mathrm{C}, \mathrm{F}, \mathrm{I}) \mathrm{SA}$ kezelést követően fényben $(\square)$ és sötétben ( $\square)$ (Átlag $\pm \mathrm{SE}, \mathrm{n}=5, P \leq 0,05$ ). 


\subsubsection{A kataláz enzim aktivitása és az izoenzimeket kódoló gének expressziója}

A KAT aktivitása kontroll körülmények között nem mutatott különbséget a VT és $N r$ növények leveleiben, azonban 24 óráig tartó sötétkezelés hatására a KAT aktivitása a vad típusban csökkent, míg az ET receptor mutáns növényekben szignifikánsan emelkedett a kontrollhoz képest (39. ábra A).

Mindkét általunk alkalmazott SA koncentráció normál fotoperióduson és sötétben egyaránt szignifikánsan csökkentette a VT növények KAT aktivitását. Ezzel szemben míg a normál fotoperióduson kezelt $\mathrm{Nr}$ növényekben ez a gátló hatás csak kisebb mértékben jelentkezett, addig sötétben a KAT aktivitása szignifikánsan megemelkedett (39. ábra A, B, C).

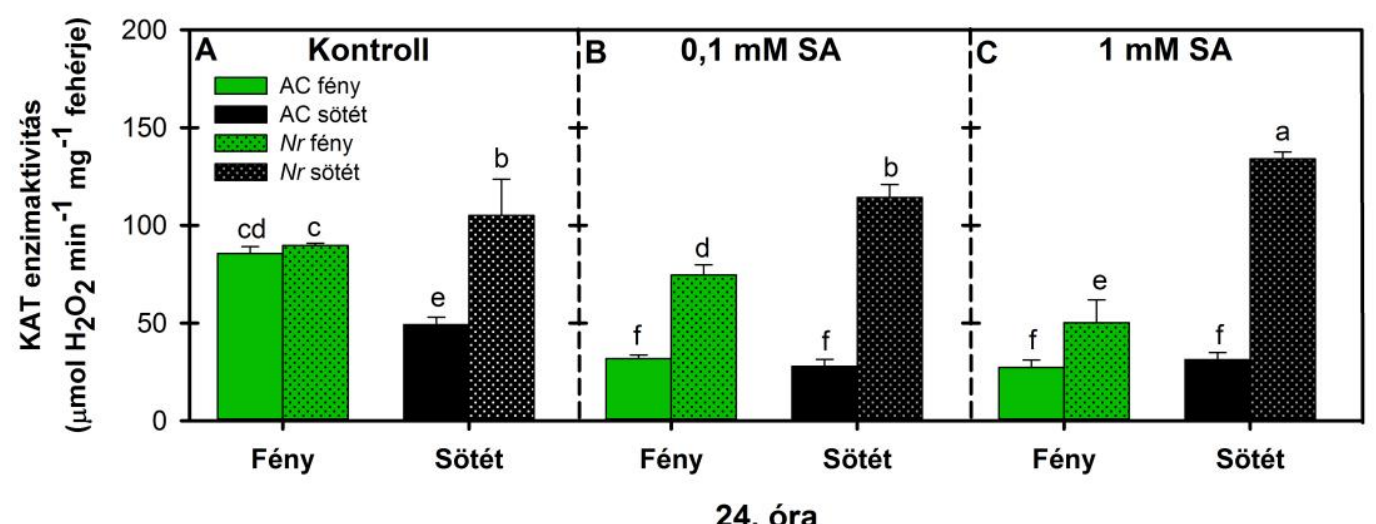

39. ábra: A KAT aktivitásának változása $\left(\mu m o l \mathrm{H}_{2} \mathrm{O}_{2} \mathrm{~min}^{-1} \mathrm{mg}^{-1}\right.$ fehérje) vad típusú (AC) és $\mathrm{Nr}$ paradicsom növények leveleiben kontroll körülmények között (A), valamint 24 óráig tartó $0,1 \mathrm{mM}$ (B) és $1 \mathrm{mM}(\mathrm{C}) \mathrm{SA}$ kezelést követően fényben $(\square)$ és sötétben $(\square)$ (Átlag $\pm \mathrm{SE}, \mathrm{n}=5, P \leq 0,05$ ).

Mindhárom általunk vizsgált KAT izoenzimet kódoló gén relatív transzkript szintje szignifikánsan alacsonyabb volt a kontroll $\mathrm{Nr}$ növények leveleiben a vad típushoz képest. A sötétben kezelt kontroll VT és $N r$ növények leveleiben, az általunk vizsgált három KAT izoenzimet kódoló gén közül csak az SlKAT2 gén expressziója mutatott szignifikáns csökkenést, míg az SIKATl és SIKAT3 gének relatív transzkript szintjei nem mutattak szignifikáns változást a fényben tartott növényekhez képest (40. ábra A, D, G).

Normál fotoperióduson történő 0,1 mM SA kezelés szignifikánsan csak az SlKAT1 gén relatív transzkript szintjét csökkentette a VT növények leveleiben, míg az általunk vizsgált három izoenzimet kódoló gén közül egyik gén sem mutatott szignifikáns változást az $\mathrm{Nr}$ növények leveleiben (40. ábra B, E, H). A vad típus sötétben történő 0,1 mM SA kezelése szignifikánsan csökkentette az SIKAT1 és SIKAT3 gének expresszióját, ezzel szemben az SlKAT1 gén expressziója szignifikánsan megemelkedett az $N r$ növények leveleiben (40. ábraB, E, H). 
1 mM SA-val történö kezelés során a 0,1 mM SA-hoz hasonló KAT gén expressziókat tapasztaltunk a normál fotoperióduson, valamint a sötétben kezelt VT és $N r$ növények leveleiben is (40. ábra C, F, I). Kivéve az SIKAT3 gént, amely a VT növényekben normál fotoperióduson, míg az $N r$ növényekben sötétben mutatott szignifikáns emelkedést (40. ábra C, I).

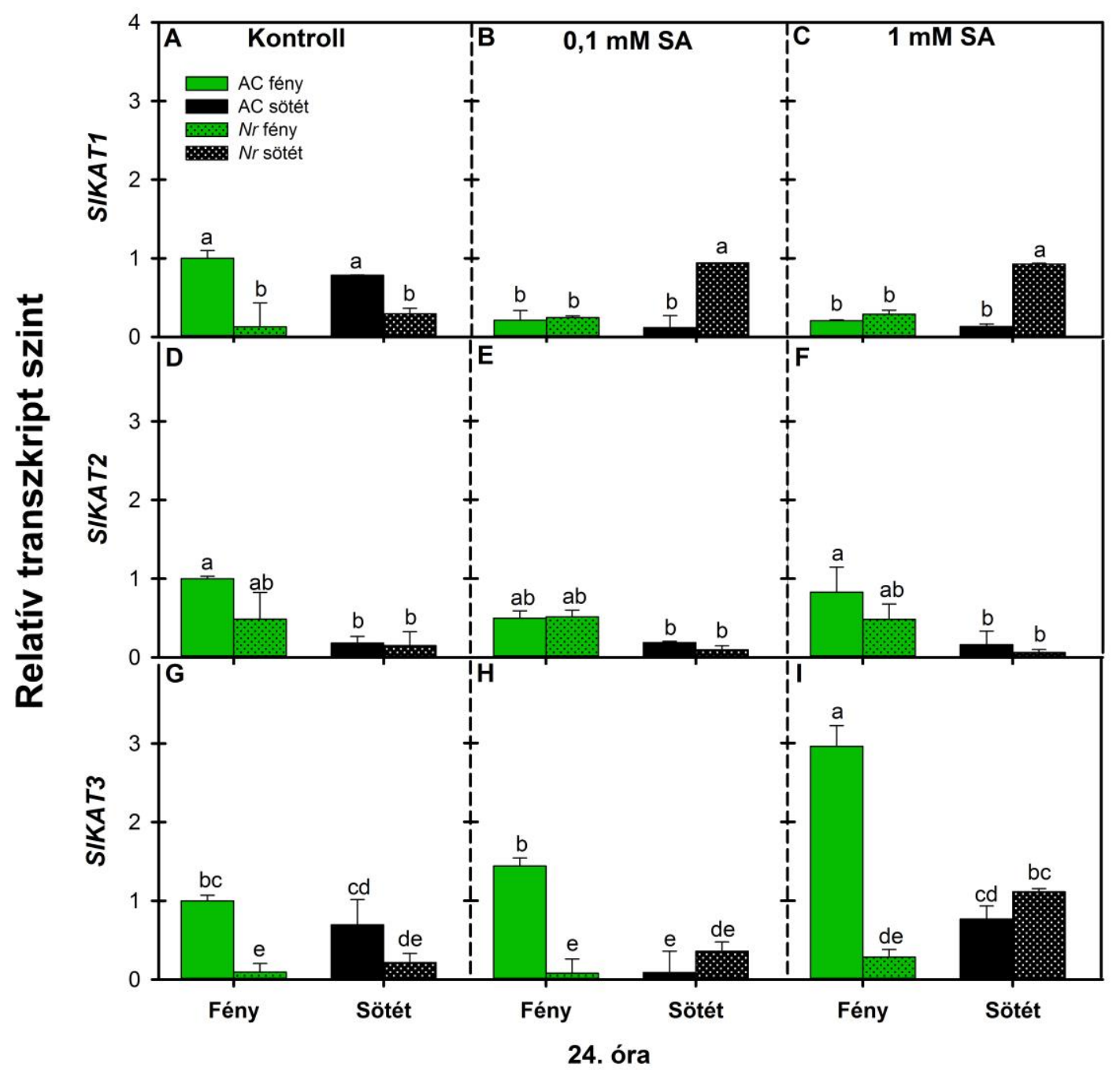

40. ábra: A KAT izoenzimeket kódoló gének [SIKAT1 (A, B, C); $\operatorname{SlKAT2~(D,~E,~F);~} \operatorname{SlKAT3~(G,~H,~I)]~}$ expressziójának változása vad típusú (AC) és $N r$ paradicsom növények leveleiben kontroll körülmények között (A, D, G), valamint 24 óráig tartó $0,1 \mathrm{mM}(\mathrm{B}, \mathrm{E}, \mathrm{H})$ és $1 \mathrm{mM}(\mathrm{C}, \mathrm{F}, \mathrm{I}) \mathrm{SA}$ kezelést követően fényben $(\square)$ és sötétben $(\square)$ (Átlag $\pm \mathrm{SE}, \mathrm{n}=5, P \leq 0,05$ ).

\subsubsection{Az aszkorbát-peroxidáz enzim aktivitása és az izoenzimeket kódoló gének expressziója}

A következőkben megvizsgáltuk a $\mathrm{H}_{2} \mathrm{O}_{2}$ eliminálásában fontos szerepet játszó APX enzim aktivitásának és expressziójának változását is mindkét genotípusban.

Kontroll VT és $N r$ növények 24 óráig tartó sötétkezelése nem okozott szignifikáns változást az APX aktivitásában a normál fotoperióduson nevelt kontroll növényekhez képest (41. ábra A). Fényben történő szubletális és letális SA kezelés hatására azonban mindkét 
általunk vizsgált genotípusban szignifikánsan megemelkedett az APX aktivitása, míg ha a növényeket sötétben kezeltük, az APX enzim nem mutatott különbséget a kontrollhoz képest (41. ábra A, B, C).

Natív PAGE segítségével mindkét genotípusban két APX izoformát tudtunk elkülöníteni (41. ábra D). Ezek az eredmények jól korreláltak a fotométeres eredményeinkkel, ugyanis fényben történő $1 \mathrm{mM}$ SA kezelés hatására mindkét genotípusban szignifikáns APX aktivitásnövekedést kaptunk, míg sötétben az APX aktivitása nem változott a kontrollhoz képest (41. ábra D).

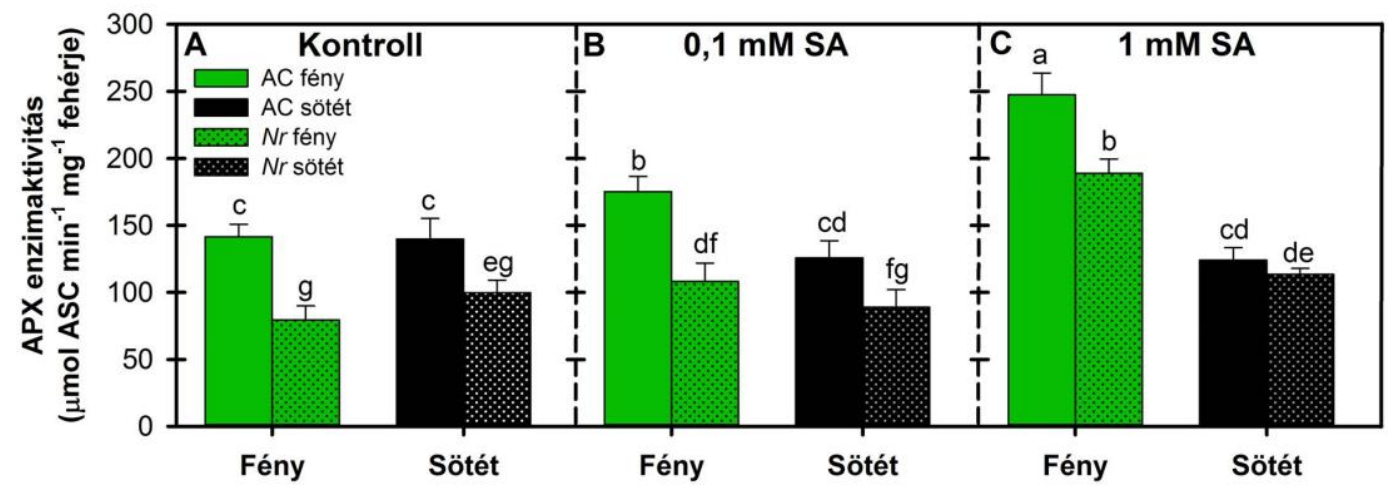

24. óra

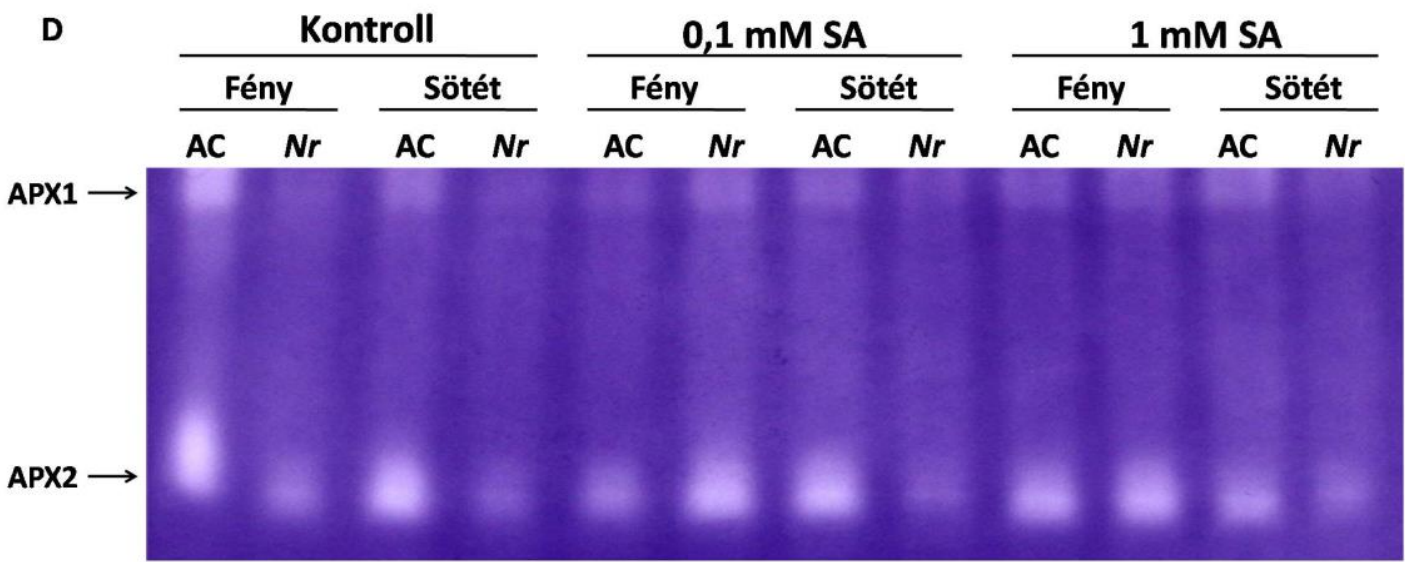

24. óra

41. ábra: Az APX enzim aktivitásának változása ( $\mu$ mol ASC $\min ^{-1} \mathrm{mg}^{-1}$ fehérje) vad típusú (AC) és $N r$ paradicsom növények leveleiben kontroll körülmények között (A), valamint 24 óráig tartó $0,1 \mathrm{mM}(\mathrm{B})$ és $1 \mathrm{mM}(\mathrm{C}) \mathrm{SA}$ kezelést követően fényben ( $\square$ ) és sötétben ( $\square$ ) (Átlag $\pm \mathrm{SE}, \mathrm{n}=5, P \leq 0,05$ ). Az APXizoenzimek változása natív gélben, szelektív festést követően (D). Az itt látható gélkép egy reprezentatív kísérlet eredménye, melyet három alkalommal ismételtünk meg.

Az SlAPX1 és különösen az SlAPX2 gén relatív transzkript szintje az $N r$ kontroll növényekben alacsonyabb szintet mutatott a VT-hez képest, míg 24 óráig tartó sötétkezelés mindkét általunk vizsgált gén expresszióját szignifikánsan csökkentette a VT és $\mathrm{Nr}$ növények leveleiben (42. ábra A, D). 0,1 mM SA kezelés során a kontrollhoz hasonló tendencia figyelhető meg mindkét általunk vizsgált körülmény esetén (42. ábra B, E). Ezzel szemben az 1 mM SA kezelés az SlAPX1 és SlAPX2 gének szignifikáns indukcióit eredményezte normál 
fotoperióduson kezelt VT növények leveleiben, míg az $N r$ növények leveleiben mindkét gén expressziója szignifikánsan csökkent a kontrollhoz képest. Azonban mindkét genotípus sötétben történő letális SA kezelése nem okozott szignifikáns változást az APX izoenzimeket kódoló gének expresszióiban (42. ábra C, F).

A kapott eredmények alapján összességében megállapítható, hogy az APX enzim aktivitása és expressziója szignifikánsan magasabb volt a VT növények leveleiben, mint az ET receptor mutáns, $\mathrm{Nr}$ növényekben, kivéve az SlAPX1 expresszióját normál fotoperióduson kontroll és 0,1 mM SA kezelés során. Továbbá, hogy az APX aktivitása és expressziója fényben történő szubletális és letális SA kezelés során kisebb mértékben emelkedett meg az ET jelátvitel hiányában, ami arra utalhat, hogy az ET indukálta folyamatoknak szerepe lehet az APX aktivitásának szabályozásában is, mely hatás sötétben történő kezelés során nem érvényesül.

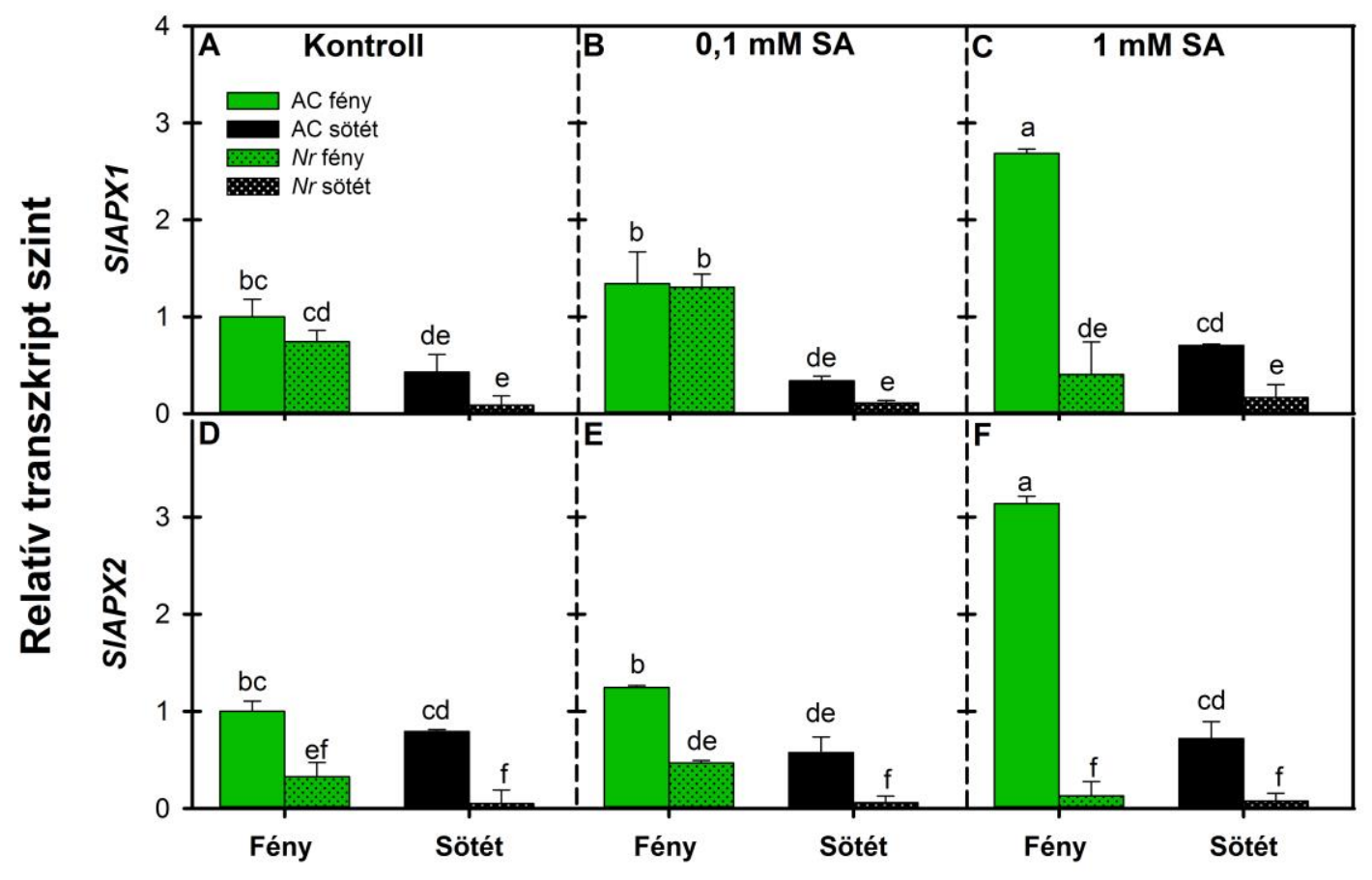

24. óra

42. ábra: Az APX izoenzimeket kódoló gének [SlAPX1 (A, B, C); SlAPX2 (D, E, F)] expressziójának változása vad típusú (AC) és $N r$ paradicsom növények leveleiben kontroll körülmények között $(\mathrm{A}, \mathrm{D})$, valamint 24 óráig tartó $0,1 \mathrm{mM}(\mathrm{B}, \mathrm{E})$ és $1 \mathrm{mM}(\mathrm{C}, \mathrm{F})$ SA kezelést követően fényben ( $\square$ ) és sötétben (ם) (Átlag $\pm \mathrm{SE}, \mathrm{n}=5, P \leq 0,05)$.

\subsubsection{A gvajakol-peroxidáz enzim aktivitása}

Végül megvizsgáltuk a POD enzim aktivitását is, amely a KAT és az APX mellett ugyancsak a $\mathrm{H}_{2} \mathrm{O}_{2}$ eliminálásában játszik fontos szerepet. A normál fotoperióduson kezelt VT növények leveleiben a POD aktivitása fény- és koncentráció-függő módon emelkedett meg, míg ha a növényeket sötétben kezeltuik, a POD aktivitása kisebb mértékben indukálódott (43. ábra B, C). 
Érdekesség, hogy az $N r$ növényekben mérhető POD aktivitása nem mutatott szignifikáns változást egyik SA kezelés hatására sem (43. ábra A, B, C).

Fotométeres eredményeink jól korreláltak a natív PAGE-el történő elválasztásunkkal is, ahol két POD izoformát tudtunk elkülöníteni (43. ábra D). Elmondható, hogy itt is a vad típusban kaptunk magasabb aktivitást (43. ábra D), ugyanakkor megállapítható, hogy a POD enzim fénytől független módon, azonban az ET jelátvitelétől nagymértékben szabályozott.

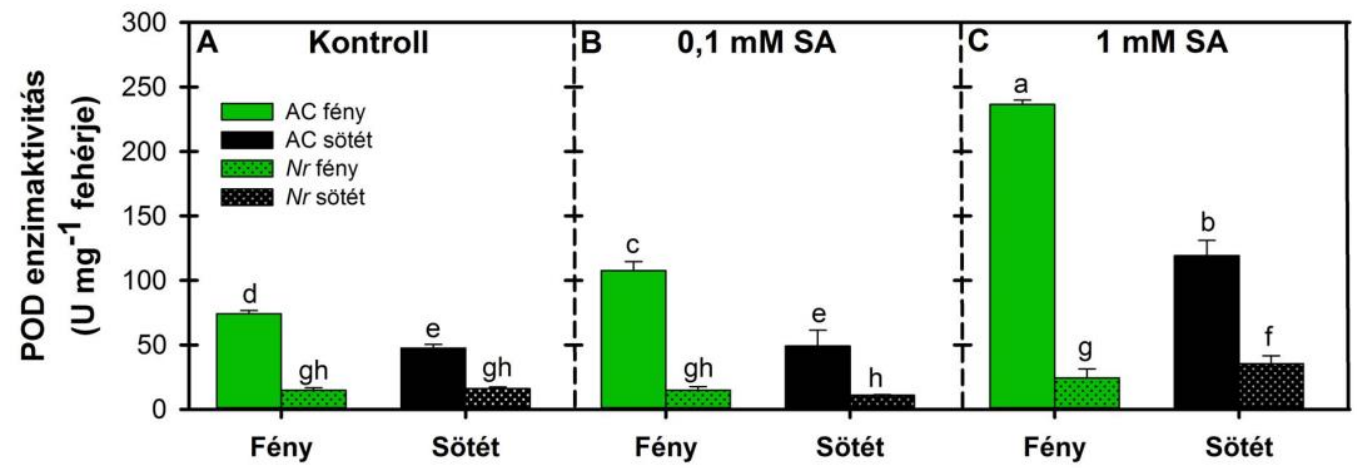

24. óra

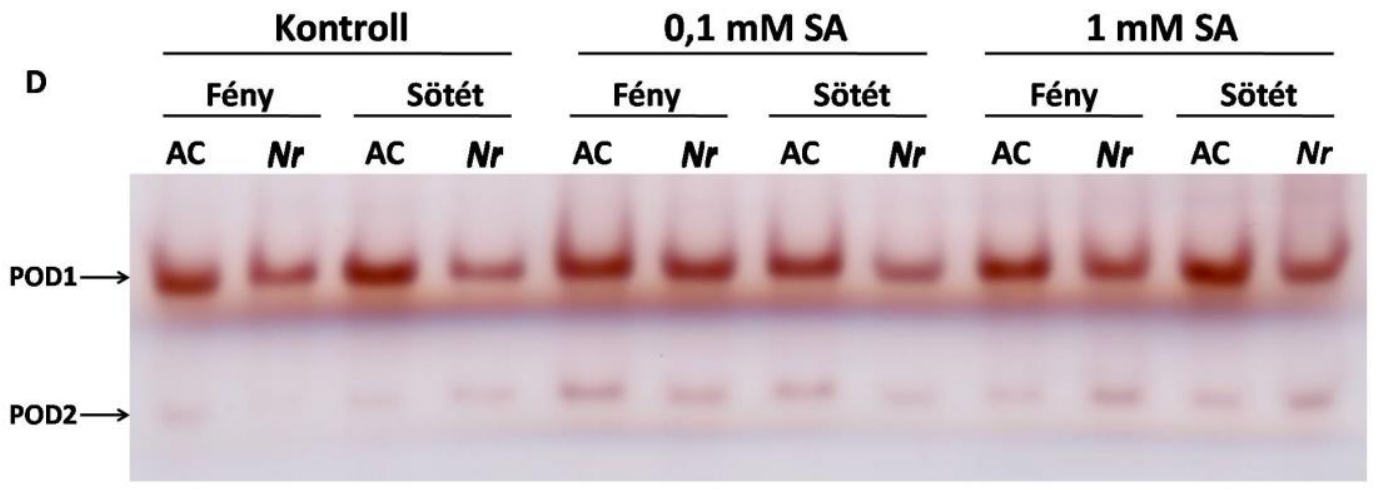

24. óra

43. ábra: A POD aktivitásának változása ( $\mathrm{U} \mathrm{mg}^{-1}$ fehérje) vad típusú (AC) és $N r$ paradicsom növények leveleiben kontroll körülmények között (A), valamint 24 óráig tartó $0,1 \mathrm{mM}$ (B) és $1 \mathrm{mM}$ (C) SA kezelést követően fényben ( $\square$ ) és sötétben (ם) (Átlag $\pm \mathrm{SE}, \mathrm{n}=5, P \leq 0,05$ ). A POD-izoenzimek változása natív gélben $(\mathrm{D})$. Az itt látható gélkép egy reprezentatív kísérlet eredménye, melyet három alkalommal ismételtünk meg. 


\section{Eredmények értékelése}

\subsection{A normál fotoperióduson és sötétben történö SA kezelések hatása a vad típusú AC növények életképességére és PA-ok metabolizmusára}

Az SA a növényi szövetekben koncentrációtól függő módon képes szabályozni számos biokémiai és molekuláris biológiai folyamatot (Hayat és mtsai., 2010). Korábbi vizsgálataink során kimutattuk, hogy a szubletális, $0,1 \mathrm{mM}$ koncentrációjú SA fokozta a sóstresszel szembeni toleranciát (Tari és mtsai., 2002; Szepesi és mtsai., 2005; Szepesi és mtsai., 2009; Gémes és mtsai., 2011), míg ha a paradicsom növényeket letális, 1 mM SA-val kezeltük a sejthalál indukciója volt megfigyelhető (Poór és mtsai., 2011). Az endogén SA 0,1 és $10 \mu \mathrm{g} / \mathrm{g}$ FT közötti koncentrációban még nem okoz oly mértékü oxidatív stresszt, amely során sejthalál kiváltódna, amikor azonban az endogén SA koncentrációja meghaladja a fajspecifikus határértéket vagy a külsőleg adott SA koncentrációja nagyobb, mint $1 \mathrm{mM}$, oxidatív stressz és PCD történik (Poór és mtsai., 2013; Chen és mtsai., 2016).

A munkám során ezért célul tüztük ki annak vizsgálatát, milyen különbségek figyelhetők meg az általunk előzőleg kiválasztott, szubletálisnak $(0,1 \mathrm{mM})$ és letálisnak (1 mM) bizonyuló SA koncentrációk rövidtávú, 24 óráig tartó hatása között vad típusú AC paradicsom növényekben normál fotoperióduson vagy sötétben. Az SA kezelést követő első 24 óra ugyanis különösen fontos a növények akklimatizációja vagy a sejthalál indukciója szempontjából. Emellett ugyanakkor van den Burg és Takken (2009) azt is kimutatták, hogy az SA felhalmozódása és az SA-indukálta transzkripciós szabályozás már nagyon rövid időn belül megtörténik a patogénfertőzést követően. Megkülönböztethető ugyanis egy korai (0-6 óráig) és egy késői (6-24 óráig) szakasz a transzkripcionális és a kromatin átrendeződés szabályozásában. Genoud és mtsai. (2002) fényt derítettek arra is, hogy az SA által indukált védelmi reakciók, például a ROS termelődése, valamint a HR kialakulása fényfüggő folyamatok. Így a fény hiánya döntő fontosságú lehet ebben a 24 órás időintervallumban. Liu és mtsai. (2011) kimutatták továbbá, hogy a fertőzést követő, SA-indukálta SAR kialakítása két egymással együttműködő útvonalon keresztül történik, amelyek közül az egyikhez szükséges a fény, míg a másikhoz nem. Ezért elsőként megvizsgáltuk, hogy a különböző koncentrációkban alkalmazott külső SA kezelések, hogyan befolyásolták az endogén szabad és kötött SA mennyiségét az idő függvényében, valamint, ezek felhalmozódását milyen mértékben befolyásolja a normál fotoperióduson és a sötétben történő kezelések. 
A VT növények leveleinek endogén SA koncentrációját megmérve azt tapasztaltuk, hogy a szabad és a kötött SA mennyisége normál fotoperióduson történő $0,1 \mathrm{mM}$ SA kezelés hatására 80 szorosára emelkedett, amely a kezelést követő 6. órában már elérte a maximumát. Míg a sötétben történő kezelés később és kisebb mértékben emelte meg az endogén szabad, kötött és összes SA mennyiségét. Ezzel szemben mindkét körülmény esetén, az $1 \mathrm{mM} \mathrm{SA}$ hatására az endogén szabad SA koncentrációja addig növekedett, míg a kontrollhoz képest 1200 szorosára nőtt. Gharbi és mtsai. (2016) hasonló eredményeket kaptak, miszerint az exogén 0,01 mM SA-val történő kezelés 100 szorosára emelte az endogén SA tartalmakat AC paradicsom növények leveleiben. Megállapítható, hogy mindkét SA kezelést követően a 24. órában a szabad és a teljes SA tartalmak nem mutattak szignifikáns különbséget a normál fotoperióduson vagy a sötétben kezelt VT paradicsom növények leveleiben.

A következőkben megvizsgáltuk, hogyan hat az idő függvényében a két általunk választott SA koncentráció a növények életképességére, valamint a szabad PA-ok metabolizmusára normál fotoperióduson vagy sötétben. Az irodalomból ismert, hogy a sejtek membránintegritásának fenntartása szerves részét képezi a stressztolerancia kialakításának. Az irreverzibilis ionkieresztés, mely a sejthalál indukciójának egyik eleme, csak a normál fotoperióduson történő $1 \mathrm{mM}$ SA kezelés hatására emelkedett meg, a visszafordíthatatlan $40 \%$ körüli értékre, míg ez a hatás a 0,1 mM SA, valamint az $1 \mathrm{mM}$ SA sötétben történő kezelése során kisebb mértékü volt. A membrán integritásának elvesztésével párhuzamosan változott a lipidperoxidáció mértékét jelző MDA tartalom is, amely az oxidatív károsodás egyik indikátora (Sharma és mtsai., 2012). Fényben történő 1 mM SA kezelés szignifikánsan növelte az MDA mennyiségét, míg sötétben ez a hatás kisebb mértékü volt. A kapott eredmények azt mutatják, hogy az SA-nak koncentráció- és fényfüggő hatása van a membrán integritására és a sejthalál indukciójára.

A PA-oknak mint kis molekulatömegü polikationoknak, fontos szerepük van a PM integritásának és szelektív permeabilitásának megőrzésében. Exogén PA kezelések csökkentették a lipidperoxidáció mértékét, a $\mathrm{H}_{2} \mathrm{O}_{2}$ és MDA tartalmak mennyiségét az enzimatikus és nem enzimatikus antioxidánsok aktiválásán keresztül (Li és mtsai., 2015b). A PA kezelések emellett képesek megnövelni a sejtek túlélését közvetlen ROS-kioltó hatásuk miatt. Túl magas koncentrációban azonban citotoxikus prooxidánsként is viselkedhetnek, mivel a terminális katabolizmusuk során a melléktermékként keletkezett $\mathrm{H}_{2} \mathrm{O}_{2}$ hozzájárulhat az oxidatív robbanás későbbi, második csúcsához, ezáltal pedig a PCD kiváltásához (Moschou és Roubelakis-Angelakis 2014; Pottosin és mtsai., 2014). A szabad PA-ok egymáshoz viszonyított sejten belüli aránya is döntő fontosságú a stresszel szembeni tolerancia vagy a sejthalál indukciójában. A VT paradicsom növények PA tartalmában bekövetkező változások napszakos 
(diurnális) ciklust mutattak kontroll körülmények között. Normál fotoperióduson a szabad Put, Spd és Spm mennyisége a napi ciklus közepén érte el maximumát. Hasonló eredményt kaptak Gemperlová és mtsai. (2006) dohány növények leveleiben is. Azonban 24 óráig tartó sötétkezelés hatására a Put és Spd korábbi felhalmozódása volt megfigyelhető. Normál fotoperióduson történő szubletális SA kezelés hatására a szabad PA-ok napi ciklusa nagymértékben megmaradt, azonban a sötétben történő kezelés a Put és Spm tartalmakat korábban, már a kezelést követő első órában szignifikánsan megemelte. A letális, $1 \mathrm{mM} \mathrm{SA}$ kezelést követően szignifikánsan megemelkedett a Put és Spm mennyisége a vad típusú AC növények leveleiben, különösen a sötétben történő kezelés során. Feltételezzük, hogy sötétben a korai Spm és a késő Put felhalmozódása hozzájárulhat az $1 \mathrm{mM}$ SA által indukált sejthalál késleltetéséhez a vad típusú AC paradicsom növények leveleiben. A Put és Spm felhalmozódásának fontos szerepe lehet a sejtek életképességének javításában, ezáltal pedig a sejthalál késleltetésében, mivel a Put csökkenti a $\mathrm{H}_{2} \mathrm{O}_{2}$ indukálta PCD kialakulását, valamint oxidatív stressz alatt szabályozza az antioxidáns enzimek aktivitását is. Az Spm ugyanakkor gátolta a PM lokalizált NOX enzim müködését is, ezáltal pedig a $\cdot \mathrm{O}_{2}{ }^{-}$keletkezését szőlő és dohány protoplasztokban (Papadakis és mtsai., 2005). Yaakoubi és mtsai. (2014) kimutatták azt is, hogy az Spd és Spm hozzájárul a fotoinhibíció során károsodott tilakoid membránok védelméhez, valamint a PSI stabilitásához, továbbá, hogy a megemelkedett Spm képes a tilakoidban keletkezett $\cdot \mathrm{O}_{2}^{-}$kioltására is.

A sejten belüli PA-ok mennyiségének kontrollált szabályozása is kulcsfontosságú a sejt túlélése szempontjából (Jimenez-Bremont és mtsai., 2014). A sejten belüli PA-koncentráció függ a PA-ok bioszintézisében (ADC, ODC, SPDS, SPMS) és lebontásában (DAO, PAO) szerepet játszó fehérjék génjeinek transzkripciójától és transzlációjától is, a vakuoláris és apoplasztikus transzportjuktól, illetve fenolos származékokkal történő konjugációjuktól (Wallace és mtsai., 2003). Irodalmi adatokból ugyanakkor tudjuk, hogy a gyökerekben szintetizált PA-ok képesek a xilémparenchima sejtekben található transzmembrán fehérjéken keresztül a hajtásba transzportálódni. Ebben egy L-típusú aminosav transzporter (LAT) játszik fontos szerepet szabályozva ezáltal a hajtás PA tartalmát (Fujita és Shinozaki 2015).

A következőkben megvizsgáltuk, hogy az SA kezelések hatására a PA tartalomban bekövetkezett változásokat milyen mértékben befolyásolja a bioszintézisükben és a lebontásukban szerepet játszó enzimek aktivitása és expressziója. Kontroll körülmények között a Put bioszintézisében szerepet játszó SIADC és $S I O D C$, az Spd bioszintézisében szereplő SISPDS, valamint az Spm bioszintézisében fontos SISPMS gének relatív transzkript szintjei diurnális expressziót, valamint nagyobb indukciót mutattak a sötétben tartott kontroll növényekhez képest. Kísérletünkben a szubletális és a letális SA kezelések eltérő módon 
befolyásolták az ADC és ODC enzimeket kódoló gének expresszióját. 0,1 mM SA kezelést követően csak az SlADC gén expressziójában tapasztaltunk szignifikáns indukciót, azonban, ha a növényeket a letális SA koncentrációval kezeltük, mindkét gén kifejeződött, bizonyítva, hogy az SA-indukálta biotikus stressz során az ADC enzimaktivitásának nagyobb szerepe lehet a Put bioszintézisében. Továbbá elsőként sikerült kimutatni, hogy a letális SA kezelés a szubletális SA koncentrációhoz képest nagyobb mértékben növelte az SlADC, SlODC és SISPMS gének expresszióját, míg az SISPDS gén relatív transzkript szintje csak kismértékben emelkedett meg, melyek jól korreláltak a szabad PA-ok mennyiségében bekövetkező változásokkal is. Összefoglalásképpen elmondható, hogy az első 24 órában az SA indukálta PA akkmumulációjához nagymértékben hozzájárulnak a PA-ok bioszintézisében szerepet játszó gének expressziójának növekedései.

Gemperlová és mtsai. (2006) kimutatták, hogy a Put mennyiségében bekövetkező változások szoros kapcsolatban állnak a lebontásukat katalizáló DAO enzim aktivitásával. Kísérletünkben az SA kezelést követő első 24 órában nem tapasztaltunk szoros összefüggést a Put mennyisége és a lebontását katalizáló DAO aktivitása és expressziója között, utalva egy, a PA-ok mennyiségét meghatározó komplexebb szabályozásra. Normál fotoperióduson és sötétben történő 0,1 mM SA kezelés indukálta az SIDAO1 és SIDAO2 izoenzimeket kódoló gének expresszióját, valamint az össz DAO enzim aktivitást. Ezzel szemben, ha a VT növényeket a letális SA koncentrációval kezeltük, csak sötétben tapasztaltunk szignifikáns emelkedést a DAO izoenzimeket kódoló gének expressziójában és az enzimaktivitásában. A kapott eredmények azt mutatják, hogy az SA kezelés során a DAO enzim aktivitása és a gének expressziója sötétben mutatott nagyobb indukciót. Az 1 mM SA nemcsak a Put bioszintézisét, hanem a lebontását is elösegítette sötétben történő kezelés során, míg ha a növényeket fényben kezeltük, nem tapasztaltunk együttesen aktiválódó bioszintézist és lebontást. A kapott eredmények alapján elmondható, hogy amíg a 0,1 mM SA leginkább a DAO enzim aktivitásán és az izoenzimeket kódoló gének expresszióján, addig az $1 \mathrm{mM}$ SA inkább a Put bioszintézisében szerepet játszó enzimek expresszióján keresztül szabályozza a szabad Put mennyiségét, amely arra utal, hogy a Put sejten belüli mennyiségének meghatározásában az SA-nak koncentráció- és fényfüggő szabályozása van.

Megvizsgáltuk az Spd és Spm lebontásában szerepet játszó PAO izoenzimeket kódoló gének expresszióját, valamint a PAO aktivitását is az SA kezeléseket követően. Normál fotoperióduson és sötétben történő szubletális és letális SA kezelések eltérő módon és eltérő mértékben befolyásolták az SIPAO1 és SIPAO2 gének expresszióját és a PAO aktivitását. A kapott eredmények alapján megállapítható, hogy mindkét SA kezelés elsősorban az SIPAO1 
relatív transzkript szintjére hatott, különösen sötétben, mely emelkedés azonban nem mutatott szoros korrelációt az enzimaktivitásokban mért adatokkal.

$\mathrm{Az}$ irodalomban ez az első olyan összehasonlító elemzés, amely szerint az SA koncentrációtól függő módon befolyásolja a szabad PA-ok mennyiségét, valamint a bioszintézisükben és lebontásukban szerepet játszó enzimek gén expresszióját és aktivitását, amelyben a fény meglétének vagy hiányának meghatározó szerepe van.

\subsection{A normál fotoperióduson és sötétben történö SA kezelések hatása a vad típusú AC növények oxidatív stresszel kapcsolatos folyamataira}

A következőkben megvizsgáltuk az SA indukálta jelátvitelben szerepet játszó ${ }^{\circ} \mathrm{O}_{2}^{-}, \mathrm{H}_{2} \mathrm{O}_{2}$ és $\mathrm{NO}$ mennyiségében bekövetkező változásokat 24 óráig tartó normál fotoperióduson vagy sötétben történő szubletális és letális SA kezeléseket követően. Az elmúlt években már bizonyítást nyert, hogy a $\mathrm{H}_{2} \mathrm{O}_{2}$ és az NO az SA jelátvitelének fontos komponense (Apparao Kolla és Raghgavendra 2007; Khokon és mtsai., 2011), azonban arról jelenleg nincs irodalmi adat, hogy ezeknek a komponenseknek a mennyisége hogyan alakul a különböző SA koncentrációk hatására az idő függvényében, normál fotoperióduson vagy sötétben.

Az exogén SA kezelések hatását a $\mathrm{O}_{2}{ }^{-}$mennyiségére in situ $\mathrm{NBT}$ festéses módszerrel határoztuk meg. A szubletális SA kezelés esetén nem tapasztaltunk egyik körülmény esetén sem megemelkedett ${ }^{\circ} \mathrm{O}_{2}{ }^{-}$termelődést. Azonban az intakt levelekben az $1 \mathrm{mM}$ SA kezelést követő első órákban csak a normál fotoperióduson figyelhettünk meg magasabb $\mathrm{O}_{2}{ }^{-}$ mennyiséget, míg ezzel szemben, ha a növényeket sötétben kezeltük kisebb mértékben és csak később emelkedett meg a $\cdot \mathrm{O}_{2}^{-}$mennyisége.

A szubletális és letális SA koncentrációk normál fotoperióduson tartott vad típusú AC paradicsom növények leveleiben szignifikánsan, de eltérő mértékben okoztak $\mathrm{H}_{2} \mathrm{O}_{2}$ felhalmozódást az idő függvényében. Ezzel szemben, ha a növényeket sötétben kezeltük később és kisebb mértékben emelkedett meg a $\mathrm{H}_{2} \mathrm{O}_{2}$ mennyisége. A két általunk használt SA koncentráció közül az $1 \mathrm{mM}$ indukálta nagyobb mértékben a $\mathrm{H}_{2} \mathrm{O}_{2}$ felhalmozódását, amely a normál fotoperióduson tartott növények leveleiben kettős csúcsot mutatott, mely kettős csúcs a sötétben kezelt növények esetében nem volt tapasztalható. Korábbi kutatások kimutatták, hogy a ROS termelődésében megfigyelhető kettős csúcs megelőzte a sejthalál indukcióját biotikus stressz során, amelyek közül az első csúcs néhány percen belül, a második pedig a stresszt követő néhány órával később jelentkezett (van Aken és van Breusegem 2015). Korábbi vizsgálataink során az előzőekben leírtakhoz hasonló ROS kinetikát tapasztaltunk, amikor a paradicsom növényeket letális, $250 \mathrm{mM} \mathrm{NaCl}$ koncentrációval kezeltük (Takács és mtsai., 2017). Nemcsak a ROS, hanem az ET termelődésében is megfigyelhető kettős csúcs, ha a 
dohány leveleket $\mathrm{H}_{2} \mathrm{O}_{2}$-vel kezelték, amely végső soron nekrózishoz és sejthalálhoz vezetett (Wi és mtsai., 2010). A sötétben történő 1 mM SA kezelése során kapott eredményeink alapján elmondható, hogy az első $\mathrm{H}_{2} \mathrm{O}_{2}$ csúcs kialakításában a fénynek döntő fontossága van.

Magasabbrendű növényekben az NO keletkezésének számos útvonala lehet. A növényi NO bioszintézisében szerepet játszó legfontosabb enzim az NR (Cohen és mtsai., 2014). Az NR gének expressziója fényfüggő, de a fény nemcsak a gének transzkripcióját indukálja, hanem hatással van a transzláció szabályozásán keresztül a fehérje képződésére is (Melo és mtsai., 2016). Az SA kezelések a $\mathrm{H}_{2} \mathrm{O}_{2}$ felhalmozódása mellett az NO termelődését is befolyásolják, amely kísérletünkben az SA koncentrációjától, továbbá a fénytől függő termelődést mutatott. Zottini és mtsai. (2007) korábbi kutatásukban kimutatták, hogy az SA koncentrációtól függő módon NO szintézist generál, azonban a rövidtávú SA kezeléseknek az NO termelődésére normál fotoperióduson és sötétben gyakorolt hatását mindezidáig nem vizsgálták. A fényben és a sötétben történő $0,1 \mathrm{mM}$ SA kezelést követő 24 órában nem tapasztalható szignifikáns NO termelődés a vad típusú AC paradicsom növények leveleiben a kontrollhoz képest. Ezzel szemben az NO szignifikáns emelkedése figyelhető meg az $1 \mathrm{mM} \mathrm{SA}$ kezelést követő hatodik órától kezdve a normál fotoperióduson, míg sötétben az NO szint emelkedése elmarad. Nemcsak a fény, hanem a PA-ok is képesek hatni az NR enzim müködésére. A sötétben tapasztalható NO hiánya az 1 mM SA kezelés után a PA-ok felhalmozódása általi NR aktivitásának csökkenésével is magyarázható. Jelenlegi munkánk során bebizonyítottuk, hogy az exogén SA kezelések fényben vagy sötétben történő alkalmazása az idő függvényében eltérő módon és mértékben hatott a ${ }^{\circ} \mathrm{O}_{2}^{-}, \mathrm{H}_{2} \mathrm{O}_{2}$ és $\mathrm{NO}$ mennyiségére $\mathrm{AC}$ paradicsom növények leveleiben. Emellett az SA kezelések hatására megemelkedő $\mathrm{O}_{2}{ }^{-}, \mathrm{H}_{2} \mathrm{O}_{2}$, és NO mennyisége koncentrációtól és időtől függő módon befolyásolja a sejtek életképességét. A kezelések során keletkező ROS és NO nemcsak egymástól függetlenül képes befolyásolni a sejtek életképességét, hanem termelödésük együttesen, egymásra hatva is irányíthatja a növényi sejtek sorsát (Gémes és mtsai., 2011). A ROS, azon belül is a $\cdot \mathrm{O}_{2}^{-}, \mathrm{H}_{2} \mathrm{O}_{2}$, valamint az NO szintjének egyidejű fokozódása ugyanis a sejtek vitalitásának csökkenését okozhatják (Locato és mtsai., 2016). A kapott eredményeink ezzel összhangban jól mutatják, hogy ahol a kezelések hatására bekövetkező ROS és NO termelődése a kontrollhoz képest együttesen szignifikánsan magasabb volt, szignifikánsan emelkedett a sejtek életképességéről információt adó, a lipidperoxidáció mértékét jelző MDA tartalom, valamint a membrán integritását jelző EL értéke, ami különösen igaz a normál fotoperióduson történő $1 \mathrm{mM}$ SA-val kezelt növények leveleire. Ezzel szemben, ha a növényeket sötétben kezeltük a letális SA koncentrációval, a levelek szignifikánsan kisebb mértékü MDA tartalmat, EL értéket és ${ }^{\circ} \mathrm{O}_{2}^{-}, \mathrm{H}_{2} \mathrm{O}_{2}$ termelődést mutattak, míg az NO mennyisége nem adott szignifikáns változást a kontrollhoz képest. Így ha a kezelés sötétben történt a 
szövetek kisebb mértékü oxidatív- és nitrozatív stressznek voltak kitéve, amely a sejthalál indukciójának folyamatait késleltette az AC paradicsom növények leveleiben.

A fényben és a sötétben történő SA kezelések hatása közötti különbségek a kloroplasztiszok stresszválaszban betöltött fontosságát is mutatják. Irodalmi adatok alapján tudjuk, hogy a kloroplasztiszoknak kitüntetett szerepe van a HR-ben, elsősorban a ROS generálásán keresztül (Coll és mtsai., 2011). Azonban a fény által indukált ROS más sejtkompartmentumokból is származhat. A $\mathrm{HR}$ során a gyors $\mathrm{H}_{2} \mathrm{O}_{2}$ felhalmozódásához hozzájárul a PM kötött NOX (respratory burst oxidase homolog, Rboh) aktivitása is (Kärkönen és Kuchitsu 2015). Lúdfü genomban 10 AtRboh izoenzimet kódoló gént találtak, amelyek közül az AtRbohD és AtRbohF kulcsfontosságú a biotikus stresszfolyamataiban (Torres és Dangl 2005). A NOX aktivitásán keresztül keletkezett apoplasztikus $\cdot \mathrm{O}_{2}{ }^{-}$és $\mathrm{H}_{2} \mathrm{O}_{2}$ fontos szereppel bír továbbá a ROS sejtről sejtre történő jelátvitelében, valamint a SAR kialakításában egyaránt (Podgórska és mtsai., 2017). A paradicsomban található (SIRBOH1) enzim aktivitásának indukciója $\mathrm{Ca}^{2+}$ és a $\mathrm{Ca}^{2+}$-függő foszforiláció által is szabályozott (Sagi és Fluhr 2006). Ennek oka, hogy a növényi RBOH fehérje amino terminálisán egy kálcium megkötéséért felelős, EF kar található. Az SA-indukálta NOX aktivitásának változását és a $\mathrm{O}_{2}{ }^{-}$termelödésében betöltött szerepét már jól feltérképezték normál fotoperióduson tartott növények leveleiben (Agarwal és mtsai., 2005), azonban ezidáig nem ismert, hogyan fejti ki hatását az SA a sötétben kezelt növények esetében. Normál fotoperióduson, a NOX enzim aktivitása a szubletális SA kezelés során a harmadik órától, míg a letális SA kezelést követően már az első órától kezdve szignifikánsan megemelkedett. Ezzel szemben, ha a növényeket sötétben $1 \mathrm{mM}$ SA-val kezeltük, a NOX aktivitásában megfigyelhető indukció később jelentkezett, amely megerősíti a fény fontosságát az enzim korai aktivációjában. Az $S I R B O H 1$ gén relatív transzkript szintje is kettős csúcsot mutatott a normál fotoperióduson történő szubletális és letális SA kezeléseket követően, míg sötétben habár a gén expressziója szignifikáns indukciót mutatott az $1 \mathrm{mM} \mathrm{SA}$ kezelést követő első órákban, ez a változás nem mutatkozott meg az enzimaktivitásban. A kapott eredmények arra utalnak, hogy az SIRBOHI gén relatív transzkript szintjét mindkét általunk használt SA koncentráció megemelte, azonban az enzimaktivitásban bekövetkező növekedés csak a sejthalált indukáló SA koncentráció esetében, csak normál fotoperióduson figyelhetők meg, mely aktivitásváltozások jól korrálálnak a ${ }^{\circ}{ }_{2}^{-}$, majd az ebböl keletkező $\mathrm{H}_{2} \mathrm{O}_{2}$ mennyiségében bekövetkező változásokkal is. van Aken és van Breusegem (2015) hasonló következtetésre jutottak, miszerint a $\mathrm{H}_{2} \mathrm{O}_{2}$ mennyiségében megfigyelhető korai csúcs közvetve a PM lokalizált NOX aktivitásából illetve egyéb sejtorganellumokból, kloroplasztiszokból és mitokondriumokból származik. Nagy fényintenzitás esetén a kloroplasztiszok a PM közelébe kerülnek, amely során az apoplasztikus $\mathrm{H}_{2} \mathrm{O}_{2}$ kihat rájuk, befolyásolva a kloroplasztikus és 
apoplasztikus szabályozta ROS jelátvitelt (Shapiguzov és mtsai., 2012; Karpiňski és mtsai., 2013). Továbbá a kloroplasztiszok kapcsolatban állnak más, a ROS termelődésében szerepet játszó intracelluláris kompartmentekkel, úgy mint a mitokondriumokkal, peroxiszómákkal, valamint a citoplazmában és a sejtfalban található DAO és PAO izoenzimekkel, melyek a PAok terminális lebontása vagy visszaalakító aktivitása révén hozzájárulnak a ROS termelődéséhez és az általa kiváltott jelátviteli folyamatokhoz (Saha és mtsai., 2015). A kapott eredmények alapján megállapítható, hogy a normál fotoperióduson történő $1 \mathrm{mM}$ SA kezelés indukálta $\mathrm{H}_{2} \mathrm{O}_{2}$ felhalmozódása szoros kapcsolatban csak a PAO enzim aktivitásával áll, míg ha a növényeket sötétben kezeltük a DAO és PAO aktivitása nem mutatott szoros korrelációt a $\mathrm{H}_{2} \mathrm{O}_{2}$ tartalmakkal, bizonyítva, hogy a PA-ok terminális oxidációja fényben csak kismértékben, míg sötétben egyáltalán nem játszik szerepet a sejthalál indukciójában.

Az SA nagy hatással bír az intakt növények levelének fotoszintézisére is (Janda és mtsai., 2014). Munkacsoportunk korábbi munkáiból ismert, hogy a 0,1 mM SA nem változtatja meg a PSII reakciócentrumok maximális kvantumhasznosítását (Fv/Fm), az effektív kvantumhasznosítást (Yield értéke), valamint a fotokémiai kioltást (qP). Ezzel szemben a letális, 1 mM SA kezelés hatására a zárósejtekben szignifikánsan csökkent az Fv/Fm, Yield és a qP értéke (Poór és mtsai., 2011), ami a PSII reakciócentrumok erőteljes gátlására és a zárósejtek magas ROS termelődésére utalhat (Asada 2006). Összefoglalásképpen elmondható, hogy normál fotoperióduson történő $1 \mathrm{mM} \mathrm{SA}$ kezelés hatására megemelkedett szöveti $\mathrm{H}_{2} \mathrm{O}_{2}$ koncentrációja elsősorban a PSII reakciócentrumában bekövetkező változásokból valamint a NOX aktivitásának növekedéséből és nem a PA-ok terminális katabolizmusából származhat.

A fotoszintetikus elektrontranszport során a PSII fotokémiai rendszerben keletkező ${ }^{1} \mathrm{O}_{2}$, valamint a PSI-ben keletkező $\cdot \mathrm{O}_{2}{ }^{-}$és $\mathrm{H}_{2} \mathrm{O}_{2}$ fontos szerepet játszik a kloroplasztisz-sejtmag retrográd szignalizációban is (Mittler és mtsai., 2011), ezáltal pedig a védelmi gének (enzimatikus- és nem enzimatikus antioxidánsok bioszintézisében szerepet játszó enzimek) expressziójának szabályozásában (Karpiňski és mtsai., 2013).

$\mathrm{Az}$ antioxidáns védelmi mechanizmusok első lépéseként a keletkezett $\mathrm{O}_{2}{ }^{-}-\mathrm{t}$, a SOD enzim $\mathrm{H}_{2} \mathrm{O}_{2}$-vé és molekuláris oxigénné alakítja (Podgórska és mtsai., 2017). A kapott eredmények alapján a normál fotoperióduson és a sötétben történő, 24 óráig tartó SA kezelések csak kismértékben emelték a SOD aktivitását. Attia és mtsai. (2009) leírták, hogy a SOD izoenzimek aktivitásai független szabályozódást mutattak a szubcelluláris kompartmentekben lévő oxidatív stressz mértékétől. Kísérletünkben a kloroplasztikus lokalizáltságú $S l C u / Z n S O D$ ot és a mitokondriális $S I M n S O D$-ot kódoló gének expressziója a fényben történő $1 \mathrm{mM} \mathrm{SA}$ kezelést követő 6 . és 12 . órában mutattak szignifikáns indukciót, mely változások a szubletális SA kezelés során nem jelentkeztek, sugallva, hogy az $1 \mathrm{mM} \mathrm{SA}$ indukálta oxidatív stressz 
fontos szerepet játszhat a $C u / Z n S O D$ és a $M n S O D$ expressziójának aktiválásában. Hasonló eredményt kapott Alscher és mtsai. (2002), amely szerint a Cu/ZnSOD, MnSOD és FeSOD aktivitása szignifikánsan emelkedett, ha lúdfü növényeket Paraquattal kezelték. A kapott eredményeinkhez hasonlóan a magas fényintenzítás indukciót eredményezett a különböző SOD izoformák aktivitásában és génexpressziójában (Attia és mtsai., 2009), azonban érdekes módon az SlFeSOD expressziója nem a normál fotoperióduson, hanem sötétben mutatott szignifikáns indukciót a kontroll és a 0,1 mM SA kezelt növények leveleiben.

A keletkezett $\mathrm{H}_{2} \mathrm{O}_{2}$-ot további enzimatikus antioxidánsok, úgy mint a KAT, APX és POD enzimek vízzé és molekuláris oxigénné alakítják (Podgórska és mtsai., 2017). Kísérletünkben Luna és mtsai. (2005) eredményeihez hasonlóan cirkadián szabályozódást mutattak az SIKAT1 és SIKAT3 izoenzimeket kódoló gének relatív transzkript szintjei normál fotoperióduson tartott kontroll levelekben, azonban az SlKAT2 expressziójában gyors csökkenést tapasztaltunk az idő függvényében. A KAT enzimfehérje érzékeny a fotoinaktivációra, amely végső soron az SA indukálta KAT enzim aktivitásának csökkenéséhez is hozzájárul. Irodalmi adatokból jól ismert, hogy az SA gátolja a KAT egyes izoenzimeinek aktivitását (Horváth és mtsai., 2007; Tari és mtsai., 2015). Kísérletünkben mindkét általunk használt SA kezelés gátolta a KAT aktivitását a kezelést követő első órában, azonban fontos, hogy ez a csökkenés a fénytöl függetlenül is megtörtént. Ugyanakkor mindkét SA kezelés normál fotoperióduson csökkentette az SIKAT1 és SIKAT3 gének expresszióját is, míg, ha a növényeket a szubletális SA-val sötétben kezeltük, mindhárom általunk vizsgált gén expressziója szignifikánsan megemelkedett.

Az APX enzim aktivitása, amely ugyancsak a $\mathrm{H}_{2} \mathrm{O}_{2}$ eliminálásában játszik fontos szerepet, mutatta a legnagyobb fényfüggést az SA kezelések során. A normál fotoperióduson történő 1 mM SA kezelés a KAT enzim aktivitásához hasonlóan gátolta az APX aktivitását is, mely enzimek együttes gátlása hozzájárulhatott az első $\mathrm{H}_{2} \mathrm{O}_{2}$ csúcs kialakításához. Az $1 \mathrm{mM}$ SA kezelést követő 6. órától a citoszolikus lokalizáltságú SlAPX1 és SIAPX2 izoenzimeket kódoló gének relatív transzkript szintjei és ezzel párhuzamosan az enzim aktivitása is szignifikánsan emelkedett a normál fotoperióduson. Érdekesség, hogy sötétben történő $1 \mathrm{mM}$ SA kezelés nem okozott szignifikáns APX aktivitás emelkedést. Korábban kimutatták, hogy az SA nemcsak az APX aktivitását, de az enzim szubsztrátjaként szolgáló ASC mennyiségét is megemelte számos növényi fajban (Tari és mtsai., 2015; Khan és mtsai., 2015), amely a FoyerHalliwell-Asada ciklus során monodehidroaszkorbáttá oxidálódik, miközben a $\mathrm{H}_{2} \mathrm{O}_{2}$ vízzé alakul (Asada 1997). Az a megfigyelés miszerint az SA fényfüggő APX aktiválódást okoz az idő függvényében, az irodalomban új eredmény. 
Az APX aktivitásában megfigyelhető változásokkal ellentétben a POD aktivitása normál fotoperióduson történő 1 mM SA kezelés hatására később, a kezelést követő 12. órától mutatott szignifikáns indukciót, mely emelkedés sötétben csak a 24. órában jelentkezett. Azonban sötétben a POD enzimaktivitásban megfigyelhető emelkedés fontos szerepet játszhat a KAT és APX enzimek aktivitásának hiányában a letális SA indukálta $\mathrm{H}_{2} \mathrm{O}_{2}$ eliminálásában.

\subsection{A normál fotoperióduson és sötétben történő SA kezelések hatása az etilén receptor mutáns, Never-ripe növények oxidatív stresszel kapcsolatos folyamataira}

A növények hormonális védekezési rendszerében az SA és ET/JA jelátviteli utak fontos szerepet töltenek be, amelyek a patogéntámadásra adott növényi védekezési válaszokat is szabályozzák (Yang és mtsai., 2015a). A patogenezis folyamatában fontos különböző jelátviteli utak lehetnek szinergista vagy antagonista kapcsolatban. Az SA antagonistaként viselkedik az ET-vel szemben (Broekgaarden és mtsai., 2015), ugyanakkor az ET az SA-val együttesen is fontos szerepet játszhat a növényi immunitás szabályozásában (Koornneef és Pieterse 2008). Az SA és ET együttes hatása stressz során a termelődésük mértékétől és idejétől is függ (Pieterse és mtsai., 2012). Az irodalomban található ellentmondások származhatnak abból, hogy az ET anyagcserében bekövetkező változásokat önmagukban vizsgálják és nem az SA által szabályozott válaszokkal közösen (Dong 1998). Kísérleteink során, ezért ET receptor mutáns, $\mathrm{Nr}$ paradicsom növényeket használtunk, melyek vizsgálata lehetőséget nyújt az ET jelátvitel szerepének az elemzésére is az SA-indukált $\mathrm{H}_{2} \mathrm{O}_{2}$ termelésében és metabolizmusában.

Az ET-nek stressz során fontos szerepe van a ROS termelődésében is (Poór és mtsai., 2013; Zhang és mtsai., 2016a). Az ET túltermelő "ethylene overproducer" eto1 és eto3 mutáns lúdfü növények érzékenyebbek a ROS-indukálta stresszre és fokozottabb oxidatív stresszindukálta sejthalált mutatnak (Rao és mtsai., 2002), míg az etr1 és ein3 "ethylene insensitive" mutánsok ezen folyamatokkal szemben nagyobb toleranciát mutattak (Overmyer és mtsai., 2000; Tuominen és mtsai., 2004). Az ET szintézise bionyítottan szükséges az oxidatív robbanás kialakításához (Mersmann és mtsai., 2010), ugyanakkor a stressz által kiváltott ROS termelődés is hozzájárulhat az ET termelődéséhez (Poór és mtsai., 2015). Kísérleteink során az 1 mM SA kezelés a VT növényekben normál fotoperióduson okozott szignifikáns $\mathrm{H}_{2} \mathrm{O}_{2}$ felhalmozódást és nagyobb mértékű szövetelhalásokat. Az irodalomhoz hasonlóan az aktív ET jelátvitel hiányában normál fotoperióduson az $N r$ mutánsok kisebb mértékü $\mathrm{H}_{2} \mathrm{O}_{2}$ mennyiséget és nagyobb toleranciát mutattak a letális SA kezelésre, azonban fény hiányában szignifikánsan megemelkedett a $\mathrm{H}_{2} \mathrm{O}_{2}$ mennyisége és nagyobb méretü léziókat és nekrotikus szövetelhalásokat tapasztaltunk a vad típushoz képest. A normál fotoperióduson, letális SA-val kezelt $\mathrm{Nr}$ növényekben az alacsonyabb $\mathrm{H}_{2} \mathrm{O}_{2}$ szint megerösítette az ET-nek az SA-indukálta $\mathrm{H}_{2} \mathrm{O}_{2}$ 
termelésben betöltött fontosságát, mely hatás nagymértékben függ a fény jelenlététől. Ha az $\mathrm{Nr}$ növényeket sötétben kezeljük más jelátviteli utak és folyamatok indukálódhatnak, mely hátterében az endogén SA-nak, ET-nek és/vagy PA-ok metabolizmusának, valamint a különböző antioxidáns enzimek aktivitásának és expressziójának változásai is állhatnak.

A $\mathrm{H}_{2} \mathrm{O}_{2}$ (Janda és Ruelland 2015) vagy az ET termelés (Wi és mtsai., 2010) és az SA tartalmak közötti változások szoros összefüggést mutathatnak, azonban az SA/ET szerepe az oxidatív stresszfolyamatában, különösen sötétben még nem teljes egészében tisztázott. Az ET indukálhatja az SA/NPR1-függő védekezési folyamatokat is (Leon-Reyes és mtsai., 2009), azonban az ET termelődését koncentrációtól függően, de a legtöbb esetben az SA gátolja (Leslie és Romani 1986; 1988). A vad típusú AC növények az SA koncentrációjától függő, de a fénytől független módon akkumulálták az endogén szabad és kötött SA mennyiségét, amely az $\mathrm{Nr}$ növények leveleiben mérhető mennyiségekhez képest 24 órával a kezelést követően szignifikánsan magasabb volt, mindkét általunk használt koncentráció és körülmény esetén. Kísérletünkben a 24 óráig tartó $1 \mathrm{mM}$ SA kezelés csökkentette az ET termelődését a VT növények leveleiben, mely hatás azonos volt normál fotoperióduson és sötétben egyaránt. Eredményeink összhangban vannak az irodalomban található eredményekkel, miszerint az SA gátolhatja az ET bioszintézisét a SAM ACC-vé, majd az ACC ET-vé történő bioszintézisének gátlásán keresztül (Bali és mtsai., 2017). Ezzel szemben az Nr növények már kontroll esetben is magasabb ET termelődést mutattak, amely az 1 mM SA kezelés hatására csak kismértékben csökkent. Vegetatív szövetekben az ET saját szintézisét negatív visszacsatolással szabályozza, vagyis gátolja, míg szeneszcencia, valamint gyümölcsérés során autokatalitikus ET termelődés figyelhető meg (Rodrigues és mtsai., 2014). Negatív visszacsatolás hiányában szignifikánsan magasabb ET felhalmozódás volt megfigyelhető az SA kezelt $N r$ növények leveleiben, mindkét általunk vizsgált körülmény esetén. Ugyanakkor fontos eredmény, hogy az exogén SA kezelés során az ET indukálta aktív jelátvitel hiánya a mutáns növényekben negatívan szabályozza az SA felvételét és a levelekben történő felhalmozódását, valamint negatív visszacsatolás hiányában pozitívan az ET termelödését, mely hatás azonban független a fény jelenlététől vagy hiányától.

A szabad PA-ok és az ET szeneszcenciában és a PCD indukcióban betöltött szerepe ellentétes, mivel a PA-ok gátolhatják, az ET pedig indukálhatja ezen folyamatokat (Müller és Munné-Bosch 2015; Pál és mtsai., 2015). Az irodalmi adatok szerint a PA-ok metabolizmusának az SA-indukálta védelmi mechanizmusokban betöltött szerepét ezidáig nem vizsgálták ET jelátviteli mutánsokban, különösen fény jelenlétében vagy hiányában. A PA-ok közül az Spd/Spm és az ET között kompetitív kapcsolat állhat fent, mivel mindhárom molekula bioszintézisének közös prekurzora a SAM. Az Spd és Spm szintéziséhez szükséges 
aminopropil csoportokat a SAM dekarboxilációja biztosítja, mely folyamatot a SAMDC enzim katalizálja (Moschou és mtsai., 2012, Tiburcio és mtsai., 2014). Kísérleteink során az aktív ET jelátvitel hiánya csökkenti az SISAMDC relatív transzkript szintjét, míg VT-ben a 24 óráig tartó 1 mM SA hatására szignifikánsan magasabb expressziót tapasztaltunk a fény jelenlétében és hiányában egyaránt. Gharbi és mtsai. (2016) hasonlóan megemelkedett SAMDC relatív transzkript szintet kaptak, ha normál fotoperióduson SA-val kezelték az AC növényeket. Az $1 \mathrm{mM}$ SA kezelés szignifikánsan emelte a VT levelekben az SISPDS és SISPMS relatív transzkript szintjét normál fotoperióduson, miközben sötétben az SlADC és SlODC gének mutattak szignifikáns indukciót, mely változások jól korreláltak a Put és az Spm tartalmakkal. Az Nr növények leveleiben a PA-ok bioszintézisében szerepet játszó gének az SA koncentrációjától függetlenül, különösen sötétben represszálódtak. Ezzel párhuzamosan aktív ET jelátvitel hiányában a kísérleteink során alkalmazott SA koncentrációk nem okoztak a VT növényekhez hasonló szignifikáns PA felhalmozódást az $N r$ növények leveleiben egyik általunk vizsgált körülmény esetén sem. Irodalmi adatokból már ismert, hogy az exogén SA kezelés hatására PA-ok felhalmozódása figyelhető meg kukoricában (Németh és mtsai., 2002), paradicsomban (Szepesi és mtsai., 2009) és bambuszban (Luo és mtsai., 2012), azonban a kapott eredményeink azt mutatják, hogy az exogén SA kezelés indukálta PA felhalmozódás egyik feltétele, fénytől független módon az aktív ET jelátvitele is lehet. A szabad PA-ok mennyiségének csökkenése más folyamatokkal együtt hozzájárulhat az SA-indukálta oxidatív stressz növekedéséhez is, ugyanis a növények stressztürésének javításában az Spd és Spm sejten belüli mennyisége kritikus fontosságú, mivel azok fontos szerepet játszanak a PM integritásának fenntartásában, proteázok és RNázok aktivitásának gátlásában (Wallace és mtsai., 2003; Roussos és Pontikis 2007; Hu és mtsai., 2012). Ugyanakkor depolarizálják a PM-át növelve az ionok kiáramlását a sejtekből, ezáltal befolyásolák a $\mathrm{Ca}^{2+}$ által közvetített jelátviteli folyamatokat is (Pottosin és Shabala 2014). Korábbi vizsgálataink során kimutattuk, hogy sóstressz során a FAD tartalmú PAO enzimek szelektív inaktiválása növelte az Spd és Spm tartalmakat, amelyek szupraoptimális koncentrációja feltételezhetően iontranszporterek aktiválásán keresztül, közvetett módon, de szignifikánsan emelte az EL és a sejthalál mértékét paradicsom növények leveleiben és gyökereiben (Takács és mtsai., 2017). A Put is fontos szerepet játszik a növényi stressztolerancia javításában, viszont magas koncentrációban hozzájárulhat a szeneszcencia folyamatának indukciójához is öregedő sejtekben (Harpaz-Saad és mtsai., 2012). További vizsgálatok kimutatták, hogy ozmotikus stressz alatt a Put csökkentette a stressz-indukálta ET termelődését a ROS szintek csökkentésén keresztül (Li és mtsai., 2004). Ezzel szemben exogén Put kezelés növelte az ET szintézisét só-szenzitív és só-rezisztens rizs növényekben, ami arra utal, hogy a PA-ok és az ET között nincs közvetlen 
antagonista kapcsolat (Quinet és mtsai., 2010). Kísérleteink összefoglalásaképpen elmondható, hogy az exogén szubletális és letális SA kezelések ellentétesen hatottak az ET termelődésére, a szabad PA-ok bioszintézisében szerepet játszó enzimeket kódoló gének expressziójára és a szabad PA-ok tartalmára, vad típusú AC és $N r$ növények leveleiben. A kapott eredmények alapján az SA-indukálta szabad PA tartalom változása az ET jelátvitel által is szabályozott, ami főleg a bioszintetikus gének szabályozásán keresztül valósul meg. Fontos eredmény továbbá, hogy az SA indukálta ET, a PA-ok bioszintézisében szerepet játszó gének relatív transzkript szintjei és a szabad PA változások függnek a fény jelenlététől az $\mathrm{Nr}$ növényekben.

A ROS, azon belül is a $\mathrm{H}_{2} \mathrm{O}_{2}$ termelődéséhez, azonban a PA-ok lebontásában szerepet játszó DAO és PAO enzimek is hozzájárulhatnak (Hou és mtsai., 2013). Az irodalomból már ismert, hogy a PAO expressziója fény hatására és az SA kezelést követő hat órán belül fokozódik (Cervelli és mtsai., 2000; Cona és mtsai., 2003; Takács és mtsai., 2016), azonban arról, hogy aktív ET jelátvitel hiányában, rövidtávú SA kezelés során, hogyan változik a DAO és PAO izoenzimeket kódoló gének expressziója és a terminális lebontásban szerepet játszó enzimek aktivitása fény jelenlétében vagy hiányában, ezidáig nem volt információnk. A két általunk vizsgált genotípus összehasonlítása során azt tapasztaltuk, hogy a DAO és PAO enzimek aktivitása magasabb volt az $N r$ növények leveleiben majdnem minden általunk vizsgált kísérleti elrendezés esetén. A letális SA-val történő kezelés normál fotoperióduson csak a DAO aktivitását, míg sötétben mindkét, a PA-ok terminális lebontásában szerepet játszó enzim müködését szignifikánsan fokozta az ET receptor mutáns növények leveleiben, mely aktivitások jól korreláltak a szabad PA-ok mennyiségének csökkenésével is. Ezzel szemben a DAO és PAO izoenzimeket kódoló gének expressziójában különösen a sötétben történő SA kezeléseket követően ellentétes hatás figyelhető meg, ugyanis a VT-ben a DAO gének indukciója, míg az $\mathrm{Nr}$ növények leveleiben a terminális katabolizmusban szerepet játszó gének repressziója volt megfigyelhető mindkét SA kezelést követően. Kísérleteink során a PA-ok katabolikus génjeiben történt expressziós változások nem mutattak korrelációt a DAO és PAO enzimaktivitásokban megfigyelhető változásokkal. Irodalmi adatok alapján ismert, hogy az enzimaktivitásokban megfigyelhető növekedések poszttranszkripciós vagy transzlációs szabályozás miatt nem mindig kapcsolódnak az enzimeket kódoló gének mRNS-ének felhalmozódásához. A kapott eredmények alapján elmondható, hogy a PA-ok lebontásában szerepet játszó gének expressziójának változása függ az exogén SA koncentrációjától, továbbá a fény jelenlététől és hiányától, ami arra enged következtetni, hogy az SA/ET-indukálta jelátvitel a fénytől függő módon szabályozza a PA katabolikus gének expresszióját. Kapott eredményeink összhangban vannak Cervelli és mtsai. (2000) kutatásaival, mely szerint 
kukorica PAO enzimeket kódoló gének promoter szekvenciája fény általi szabályozódást mutatott. A PAO izoenzimek (SIPAO1, SIPAO2) expressziójának szabályozásában eredményeink alapján elsősorban nem az aktív ET jelátvitelének, hanem a fény jelenlétének vagy hiányának van meghatározó szerepe. Az AtPAO2 és AtPAO4 transzkript szintjének és ezáltal a PAO enzim aktivitás emelkedésének fontos szerepe van az ET-indukálta $\mathrm{H}_{2} \mathrm{O}_{2}$ felhalmozódásában lúdfüben (Hou és mtsai., 2013), hasonlóan a mi rendszerünkben is, a PA-ok terminális lebontásában szerepet játszó enzimek aktivitása is hozzájárulhat az SA-indukálta $\mathrm{H}_{2} \mathrm{O}_{2}$ termelödéséhez sötétben is.

Az SA-indukálta $\mathrm{H}_{2} \mathrm{O}_{2}$ nemcsak citotoxikus prooxidánsként viselkedik, hanem másodlagos jelátviteli molekulaként képes az antioxidáns enzimek aktivitását és expresszióját is befolyásolni (van Aken és van Breusegem 2015), ezért megvizsgáltuk a $\mathrm{H}_{2} \mathrm{O}_{2}$ metabolizmusban szereplő antioxidáns enzimek aktivitását és expresszióját $N r$ mutánsban is. Kiderült, hogy paradicsomban egy ET-indukált ERF transzkripciós faktor (TERF1) kulcsfontosságú szereppel bír a ROS eliminálásában is. A TERF1 transzkripcióját "upstream" EIN3 szerü transzkripciós faktorok, úgy mint az LeEIL3 és LeEIL4 szabályozzák. Dohányban a TERF1 ektópiás expressziója elősegítette a KAT expresszióját, csökkentette a ROS felhalmozódását és ezáltal növelte a növények oxidatív stressztürését (Zhang és mtsai., 2016b).

Kísérleteink során öt különböző SOD izoformát, egy MnSOD-ot (I), egy FeSOD-ot (II) és három $\mathrm{Cu} / \mathrm{ZnSOD}$-ot (III-V) detektáltunk mindkét genotípus levelében. Hasonlóan öt SOD izoformát különböztettek meg Monteiro és mtsai. (2011) Micro-Tom vad típusú és a Micro-Tom hátterében funkcionáló $N r$ mutáns növény leveleiben. Kísérleteink során az exogén SA kezelés koncentrációtól- és fénytől függő módon emelte a $\mathrm{O}_{2}{ }^{-}$átalakulását $\mathrm{H}_{2} \mathrm{O}_{2}$-vé katalizáló SOD enzim aktivitását a vad típusú AC növények leveleiben. Aktív ET jelátvitel hiányában azonban ellentétes hatást tapasztaltunk, miszerint nem normál fotoperióduson, hanem sötétben, különösen a letális SA kezelés hatására nőtt szignifikánsan a SOD enzim aktivitása, azon belül is a kloroplasztikus lokalizáltságú $\mathrm{Cu} / \mathrm{ZnSOD}$ izoenzim működése és expressziója, mely eredmény azt mutatja, hogy az SA és az ET fényfüggően hat a SOD, különösen a $\mathrm{Cu} / Z n S O D$ aktivitására és expressziójára. A SOD enzim SA koncentrációtól-, időtől- és szervtől-függő aktiválódását már megfigyelték paradicsom (Tari és mtsai., 2015) és dohány növényekben is (Horváth és mtsai., 2007). Korábban Camejo és mtsai. (2007) kimutatták, hogy a SOD izoenzimek aktivitásai csökkentek sötétben, míg Larkindale és Huang (2004) azt találták, hogy az ET prekurzor, ACC-vel történő előkezelés fokozta a SOD enzim aktivitását hő-stressz során. Eredményeink megerősítik, hogy az 1 mM SA által indukált SOD fény- és ET-függő aktiválódást is mutat, mely megemelkedett SOD aktivitás a normál 
fotoperióduson kezelt VT és a sötétben kezelt $\mathrm{Nr}$ levelekben magyarázatul szolgálhat a $\mathrm{H}_{2} \mathrm{O}_{2}$ tartalmának növekedésére és a nektorikus foltok megjelenésére.

A $\mathrm{H}_{2} \mathrm{O}_{2}$ mennyisége nemcsak a SOD aktivitásának fokozódásán, hanem a lebontó enzimek, a KAT, APX és POD aktivitásának gátlásán keresztül is megemelkedhet. Irodalmi adatokból ismert, hogy a KAT aktivitását fehérje és gén expresszió szinten is gátolja az SA (Horváth és mtsai., 2007; Tari és mtsai., 2015), melyhez hasonló eredményt kaptunk kísérletünkben is, ahol mindkét SA koncentráció csökkentette a KAT enzim aktivitását a normál fotoperióduson tartott VT és $N r$ növényekben is. A sötétben történő SA kezelések azonban növelték a KAT aktivitását az ET receptor mutáns, $\mathrm{Nr}$ növényekben, amely a SOD egyes izoenzimeihez hasonló szabályozódására utalhat. A KAT izoenzimeket kódoló gének expresszióját megvizsgálva, azt tapasztaltuk, hogy sötétben a peroxiszómális lokalizáltságú SlKAT1 és SlKAT3 izoenzimek expressziói az enzim aktivitáshoz hasonlóan szignifikáns indukciót mutattak sötétben történő 1 mM SA kezelés hatására. Korábbi kutatásokban kimutatták, hogy a búza KAT izoenzimek expresszióját a cirkadián ritmus, valamint a sötét kezelés szabályozza (Luna és mtsai., 2005). Han és mtsai. (2015) megfigyelték dinnyében, hogy sötétben 1-metil-ciklopropén kezelés, amely képes az ET receptorokkal kölcsönhatva gátolni az ET érzékelését, fokozta a KAT aktivitását 24 óra elteltével, mely adatok a kísérleteink során kapott eredményeket is alátámasztják.

Kanazawa és mtsai. (2000) kimutatták, hogy a sötét indukálta szeneszcencia folyamatában a $\mathrm{H}_{2} \mathrm{O}_{2}$ bontásában ugyancsak fontos szerepet játszó APX aktivitása csökkent. Emellett az SA APX aktivitására gyakorolt hatása függ a kezelés módjától és a levelek korától is (Tari és mtsai., 2015), azonban olyan irányú kísérletek, ahol az APX aktivitását fényben és sötétben történő SA kezelések során hasonlították volna össze aktív ET jelátvitel hiányában ezidáig még nem történtek. Kísérleteink során habár az APX aktivitása az SA koncentrációjától függő módon emelkedett a normál fotoperióduson kezelt mindkét genotípusban, aktivitása szignifikánsan alacsonyabb volt az $N r$ mutánsokban a VT növényekhez képest, míg ha a növényeket sötétben kezeltük az APX aktivitása állandó értéket mutatott mindkét genotípusban. Az SlAPX1 és SlAPX2 gének relatív transzkript szintjei az APX enzim aktivitásához hasonló tendenciát mutattak, miszerint mindkét SIAPX gén expressziója szignifikáns indukciót mutatott fényben, míg sötétben expressziójuk csökkent, ha a VT növényeket $1 \mathrm{mM}$-os SA-val kezeltük. A megvilágítástól függetlenül, mindkét APX gén expressziója szignifikánsan alacsonyabb volt az $N r$ mutánsban a VT-hez képest, ami az aktív ET jelátvitel APX gének expressziójában való fontosságát mutatja.

Korábban kimutatták, hogy az SA előkezelésként történő alkalmazása során a citoszolban és a sejtfalban található POD izoenzimek aktivitásai koncentrációtól függő módon 
emelkedtek meg (Rao és mtsai., 1997; Ananieva és mtsai., 2004). Eredményeink alátámasztják ezt a megfigyelést, hiszen a POD enzim aktivitása az SA koncentrációjától függő módon szintén indukálódott a megvilágított VT növények leveleiben. Kimutattuk, hogy a VT-ben a POD aktivitásának sötétben történő emelkedése hozzájárulhatott a KAT és az APX indukciójának hiányában a $\mathrm{H}_{2} \mathrm{O}_{2}$ eliminálásához, mely csökkenthette az SA indukálta sejthalál kialakulását a vad típusú növényekben sötétben. Érdekes módon az SA-indukálta POD aktivitása az APX aktivitásához hasonlóan szignifikánsan alacsonyabb volt az $\mathrm{Nr}$ növényekben, mely aktivitások hiánya nagymértékben hozzájárulhatott a sötétben tapasztalt $\mathrm{H}_{2} \mathrm{O}_{2}$ szintek emelkedéséhez a mutánsban. Monteiro és mtsai. (2011) hasonlóan alacsonyabb POD aktivitást mutattak ki az $N r$ növények leveleiben a vad típushoz képest, ami az ET POD enzim aktivitásának szabályozásában betöltött szerepére utal.

Normál fotoperióduson, a letális SA kezelés hatására kimutatható $\mathrm{H}_{2} \mathrm{O}_{2}$ szint növekedéséhez a megemelkedett SOD és a lecsökkent KAT aktivitása járulhatott hozzá a VT növények leveleiben. Ezzel szemben az $N r$ mutánsok sötétben történő letális SA kezelése során kaptunk nagyobb mértékủ szövetelhalást és $\mathrm{H}_{2} \mathrm{O}_{2}$ szintet, melyhez a SOD enzim aktivitásának, valamint az SlCu/ZnSOD relatív transzkript szintjének emelkedése, továbbá az APX és POD enzimek aktiválódásának elmaradása és/vagy aktivitásának csökkenése járulhatott hozzá. A kapott eredmények azt mutatják, hogy az SA-indukálta $\mathrm{H}_{2} \mathrm{O}_{2}$ metabolizmusa különböző antioxidáns enzimek által szabályozott a VT és az ET jelátvitelben mutáns paradicsom növényekben, mely szabályozás nagymértékben függ a fény jelenlététől vagy hiányától. Az $\mathrm{Nr}$ mutáns normál fotoperióduson sokkal toleránsabbnak tünik az SA-indukálta oxidatív stresszel szemben, míg tartós sötétben sokkal szenzitívebb. 


\section{7. Összefoglalás}

Munkánk első felében megvizsgáltuk, hogy milyen különbségek figyelhetők meg a szubletális, 0,1 mM SA koncentrációval történő kezelés hatása, valamint a magasabb, $1 \mathrm{mM}$-os SA koncentráció sejthalált indukáló folyamatai között normál fotoperióduson és sötétben a vad típusú AC paradicsom növények leveleiben. Munkánk második felében választ kerestünk arra a kérdésre, hogy a szubletális és letális SA normál fotoperióduson és sötétben milyen változásokat indukál a PA-ok metabolizmusában és az oxidatív stresszt érintő folyamatokban egy ET jelátvitelben mutáns, így az ET-t érzékelni nem képes, $N r$ paradicsom növény leveleiben, mely vizsgálat lehetőséget nyújt az ET jelátvitel szerepének az elemzésére is.

Munkánk során az alábbi főbb eredmények születtek:

1. A szubletális és letális SA koncentrációk normál fotoperióduson tartott AC paradicsom növények leveleiben szignifikánsan, de eltérő mértékben emelték a $\mathrm{H}_{2} \mathrm{O}_{2}$ mennyiségét az idő függvényében. Ezzel szemben, ha a növényeket sötétben kezeltük, később és kisebb mértékben emelkedett meg a $\mathrm{H}_{2} \mathrm{O}_{2}$ mennyisége. A két általunk használt SA koncentráció közül az 1 mM-os indukálta nagyobb mértékben a $\mathrm{H}_{2} \mathrm{O}_{2}$ felhalmozódását, amely a normál fotoperióduson tartott növények leveleiben kettős csúcsot mutatott. Ez a kettős csúcs a sötétben kezelt növények esetében nem volt tapasztalható. A sötétben történő $1 \mathrm{mM}$-os SA kezelés során kapott eredményeink alapján ugyanakkor elmondható, hogy az SA-indukálta első $\mathrm{H}_{2} \mathrm{O}_{2}$ csúcs kialakításában a fénynek döntő fontossága van. Az NO felhalmozódása is csak a magasabb SA koncentráció hatására és normál fotoperióduson emelkedett meg.

2. Azokban a kísérletekben, ahol a kezelések hatására bekövetkező ROS és NO termelődése a kontrollhoz képest együttesen szignifikánsan magasabb volt, szignifikánsan emelkedett a lipidperoxidáció mértékét jelző MDA tartalom, valamint a membrán integritásának csökkenését jelző EL értéke, ami különösen igaz a normál fotoperióduson történő $1 \mathrm{mM}$ SA-val kezelt növények leveleire. Ezzel szemben, ha a növényeket sötétben kezeltük a letális SA koncentrációval, a levelek szignifikánsan kisebb mértékü MDA tartalmat, EL értéket, ${ }^{\circ} \mathrm{O}_{2}{ }^{-}$és $\mathrm{H}_{2} \mathrm{O}_{2}$ termelődést mutattak, míg az NO mennyisége nem mutatott szignifikáns változást a kontrollhoz képest. Így tehát, ha a kezelés sötétben történt, a szövetek kisebb mértékű oxidatívés nitrozatív stressznek voltak kitéve, amely a sejthalál indukciójának folyamatait késleltette az AC paradicsom növények leveleiben. Ezzel szemben a 0,1 mM SA kezelésnél, bár kismértékü oxidatív stressz kialakul a normál fotoperióduson kezelt növényekben, nitrozatív stressz 
hiányában a szövetek életképessége nem csökkent, így a szubletális, exogén SA kezelés akklimatizációs folyamatokat indukálhat mindkét körülmény során.

3. A szubletális és a letális SA kezelések eltérő módon befolyásolták a Put bioszintézisében szerepet játszó ADC és ODC enzimeket kódoló gének expresszióját. 0,1 mM SA kezelést követően csak az SlADC génexpressziójában tapasztaltunk szignifikáns indukciót, azonban, ha a növényeket a letális SA koncentrációval kezeltük, mindkét gén expressziója nőtt, bizonyítva, hogy az SA-indukálta stressz során az ADC aktivitásának nagyobb szerepe lehet a Put bioszintézisében. Továbbá elsőként sikerült kimutatni, hogy a letális SA kezelés a szubletális SA koncentrációhoz képest nagyobb mértékben indukálta az SlADC, SIODC és SISPMS gének expresszióját, míg az SISPDS gén relatív transzkript szintje csak kismértékben emelkedett meg, mely indukciók jól korreláltak a szabad PA-ok mennyiségében bekövetkező változásokkal is. Megállapítható, hogy az első 24 órában az SA-indukálta PA akkmumulációhoz nagymértékben hozzájárulhat a PA-ok bioszintézisében szerepet játszó gének expressziójának növekedése is.

4. A vizsgált két $D A O$ gén ( $S L D A O 1$ és $S L D A O 2)$ expresszióját elsősorban a szubletális SA fokozta, ez gyorsabb és jelentősebb volt sötétben. A 3. órás expressziós maximumok a DAO enzim aktivitásával is korrelációt mutattak. Emellett mindkét SA kezelés elsősorban az SIPAO1 relatív transzkript szintjére hatott, különösen sötétben, mely emelkedés azonban nem mutatott szoros korrelációt a PAO enzimaktivitásokban mért adatokkal. A normál fotoperióduson történő $1 \mathrm{mM}$ SA kezelés által indukált $\mathrm{H}_{2} \mathrm{O}_{2}$ felhalmozódása csak a PAO enzim aktivitásával mutatott korrelációt, azonban, ha a növényeket sötétben kezeltük a DAO és PAO terminális oxidáz aktivitása nem mutatott szoros kapcsolatot a $\mathrm{H}_{2} \mathrm{O}_{2}$ tartalmakkal, bizonyítva, hogy a PA-ok terminális oxidációja fényben csak kismértékben, míg sötétben egyáltalán nem játszik szerepet a sejthalál indukciójában az AC növények leveleiben.

5. Az SA koncentrációtól függő módon befolyásolja a szabad PA-ok mennyiségét, valamint a bioszintézisükben és lebontásukban szerepet játszó enzimek génjeinek expresszióját és aktivitását, amelyben a fény meglétének vagy hiányának meghatározó szerepe van, mely saját új eredményünknek tekinthető.

6. Normál fotoperióduson az $1 \mathrm{mM}$ SA 1 órán belül indukálta a NOX aktivitását, amely elsősorban felelős a szuperoxid-gyökanion gyors felhalmozódásáért. Ugyanezen mintákban az oxidatív stressz fontos szerepet játszik a $C u / Z n S O D$ és a $M n S O D$ expressziójának aktiválásában. A fénytől független módon mindkét SA koncentráció gátolta a KAT aktivitását, míg az APX aktivitása az idő függvényében mindkét környezetben és mindkét SA kezelés hatására átmenetileg csökkent a kezelést követő első órában a vad típusú AC növények leveleiben. Ez azonban a fényben a letális SA hatására újra aktiválódott az SA kezelést követő 6. órától, mely aktiválódás sötétben nem történt meg. Az a megfigyelés, miszerint az SA 
fényfüggő APX aktiválódást okoz az idő függvényében, az irodalomban új eredmény. A KAT és APX enzimek együttes gátlása hozzájárulhatott az SA kezelést követő kettős $\mathrm{H}_{2} \mathrm{O}_{2}$ csúcs közül az első csúcs kialakításához. Az 1 mM SA kezelés során a KAT és APX enzimek aktivitásának hiányában a POD aktivitásában bekövetkező indukció fontos szerepet játszhat a $\mathrm{H}_{2} \mathrm{O}_{2}$ eliminálásában, ezáltal pedig a sejthalál indukciójának késleltetésében a vad típusú növényekben.

7. Aktív ET jelátvitel hiányában normál fotoperióduson az $N r$ mutánsok kisebb mértékü $\mathrm{H}_{2} \mathrm{O}_{2}$ mennyiséget és nagyobb toleranciát mutattak a letális SA-val szemben, azonban a fény hiányában a mutánsokban tapasztaltunk szignifikánsan megemelkedett $\mathrm{H}_{2} \mathrm{O}_{2}$ felhalmozódást és nagyobb mértékü szövetelhalást. A normál fotoperióduson, letális SA-val kezelt $\mathrm{Nr}$ növényekben az alacsonyabb $\mathrm{H}_{2} \mathrm{O}_{2}$ szint megerősítette az ET-nek az SA-indukálta $\mathrm{H}_{2} \mathrm{O}_{2}$ termelésben betöltött fontosságát, mely hatás nagymértékben függ a fény jelenlététől.

8. Az exogén szubletális és letális SA kezelések eltérően hatottak az ET termelődésére, a szabad PA-ok bioszintézisében szerepet játszó enzimeket kódoló gének expressziójára és a szabad PA-ok tartalmára, AC és $N r$ növények leveleiben egyaránt. A kapott eredmények alapján az SA-indukálta szabad PA tartalom változása, különösen az Spm szintézise mindkét környezetben, valamint a Put bioszintézise sötétben az ET jelátvitel által is szabályozott, ami főleg a bioszintetikus gének szabályozásán keresztül valósul meg. Fontos eredmény továbbá, hogy az SA kezelések hatására indukálódó, PA-ok bioszintézisében szerepet játszó gének relatív transzkript szintjei és a szabad PA változások függnek a fény jelenlététől az $\mathrm{Nr}$ növényekben.

9. A PA-ok lebontásában szerepet játszó gének expressziójának változása függ az exogén SA koncentrációjától, továbbá a fény jelenlététől és hiányától. A vizsgált $D A O$ és $P A O$ izoenzimek esetén a sötétben kapott repressziót a növekvő koncentrációjú SA genotípustól függően (SlDAO1, SlPAO1) vagy attól függetlenül (SIDAO2) feloldhatja. Ez arra enged következtetni, hogy az SA/ET-indukálta jelátvitel a fénytől függő módon szabályozza a PA katabolikus gének expresszióját is. A PA-ok terminális lebontásában szerepet játszó enzimek aktivitása is hozzájárulhat az SA-indukálta $\mathrm{H}_{2} \mathrm{O}_{2}$ termelődéséhez az $\mathrm{Nr}$ növényekben, magas $\mathrm{SA}$ koncentrációnál, sötétben.

10. Normál fotoperióduson, a letális SA kezelés hatására kimutatható $\mathrm{H}_{2} \mathrm{O}_{2}$ szint növekedéséhez a megemelkedett SOD és a lecsökkent KAT aktivitása járulhatott hozzá a VT növények leveleiben. Ezzel szemben az $N r$ mutánsok sötétben történő letális SA kezelése során kaptunk nagyobb mértékủ szövetelhalást és $\mathrm{H}_{2} \mathrm{O}_{2}$ szintet, melyhez a SOD enzim aktivitásának, valamint az SlCu/ZnSOD relatív transzkript szintjének emelkedése, továbbá az APX és POD enzimek aktiválódásának elmaradása és/vagy aktivitásának csökkenése járulhatott hozzá. A kapott 
eredmények azt mutatják, hogy az SA-indukálta $\mathrm{H}_{2} \mathrm{O}_{2}$ metabolizmusa különböző antioxidáns enzimek által szabályozott a VT és az ET jelátvitelben mutáns paradicsom növényekben, mely szabályozás nagymértékben függ a fény jelenlététől vagy hiányától. Az $N r$ mutáns normál fotoperióduson sokkal toleránsabbnak tủnik az SA-indukálta oxidatív stresszel szemben, míg tartós sötétben sokkal szenzitívebb.

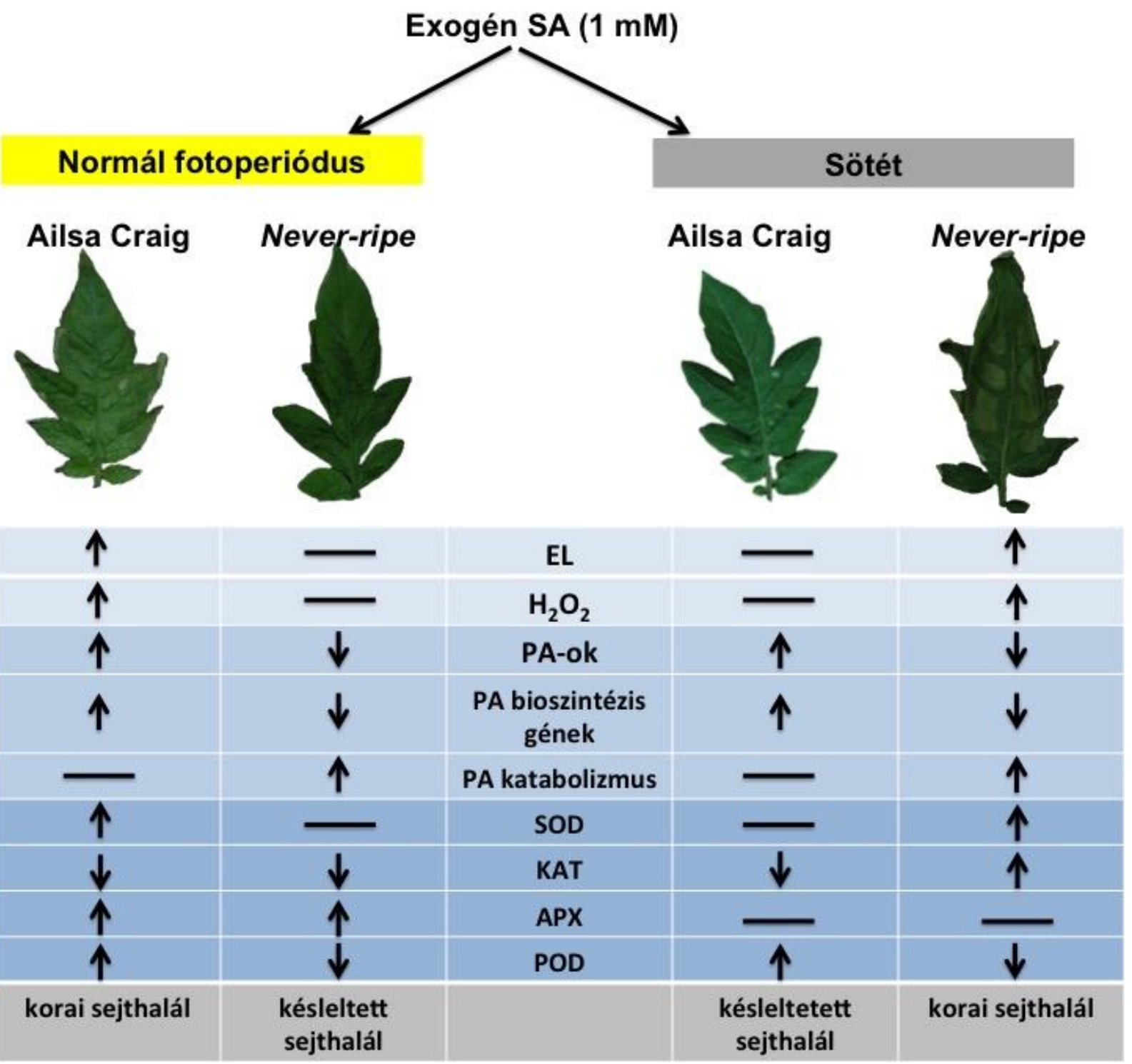

44. ábra: Az életképességnek, a PA-ok metabolizmusának, valamint az antioxidáns enzimek aktivitásának összehasonlítása 24 óráig tartó 1 mM SA kezelés hatására, normál fotoperióduson és sötétben, $\mathrm{AC}$ és $\mathrm{Nr}$ növények leveleiben. A felfele mutató nyilak aktivitás vagy koncentráció emelkedést, a lefele mutató nyilak aktivitás vagy koncentráció csökkenést mutatnak, míg az egyenes vonalak esetében nem tapasztaltunk szignifikáns változást (EL: ionkieresztés, PA: poliaminok, SOD: szuperoxid-dizmutáz, KAT: kataláz, APX: aszkorbát-peroxidáz, POD: gvajakol-peroxidáz). 


\section{Summary}

The aim of our work was to study the effects of normal photoperiod or prolonged darkness on common features or differences of oxidative stress induced by sublethal or lethal concentrations of salicylic acid (SA) in the leaves of tomato (Solanum lycopersicum cv. Ailsa Craig). Furthermore, the time- and concentration-specific induction of defence signaling was investigated in the leaves of wild type (WT) and ethylene (ET) insensitive Never ripe (Nr) mutants. Our work focused on ET-dependent effects of sublethal $(0.1 \mathrm{mM})$ and lethal $(1 \mathrm{mM})$ SA treatments under light and dark conditions on various components of oxidative stress and polyamine (PA) metabolism. Furthermore, ET receptor $\mathrm{Nr}$ mutants of tomato make it possible to analyse the role of ET signaling and the functions of ET in SA-induced $\mathrm{H}_{2} \mathrm{O}_{2}$ metabolism.

Our results can be summarized as follows:

1. In the present study, we demonstrated that sublethal and lethal SA treatments could affect $\mathrm{H}_{2} \mathrm{O}_{2}$ metabolism differently in the presence or absence of light in tomato leaves. Our results confirmed the observation that $\mathrm{H}_{2} \mathrm{O}_{2}$ accumulation of young leaf tissues was stimulated in the light by SA, but it was delayed and the maximum was lower in the prolonged dark period. Moreover, $1 \mathrm{mM} \mathrm{SA}$ induced higher $\mathrm{H}_{2} \mathrm{O}_{2}$ levels in the illuminated leaves than $0.1 \mathrm{mM} \mathrm{SA}$ and in these leaves two peaks of $\mathrm{H}_{2} \mathrm{O}_{2}$ were detected, which cannot be observed in the plants kept under prolonged darkness. The lack of the first, priming burst of $\mathrm{H}_{2} \mathrm{O}_{2}$ in the dark at $1 \mathrm{mM} \mathrm{SA}$ suggests that the early source of $\mathrm{H}_{2} \mathrm{O}_{2}$ depends on the presence of light.

2. SA has a concentration- and light dependent effects on membrane integrity, electrolyte leakage and cell death induction. SA treatments induced not only $\mathrm{H}_{2} \mathrm{O}_{2}$ accumulation but also the production of NO in a light- and concentration dependent manner. These results suggest that high SA concentration effectively induced $\mathrm{H}_{2} \mathrm{O}_{2}$ and $\mathrm{NO}$ accumulation eliciting simultaneous oxidative- and nitrosative stress and concomitant cell death in the illuminated leaves. In the dark, leaf tissues produced less $\mathrm{H}_{2} \mathrm{O}_{2}$ and $\mathrm{NO}$, which remained below the control level, the tissues were exposed to moderated stress than in the light, which slowed down the initiation of cell death program. In contrast, the treatment with $0.1 \mathrm{mM} \mathrm{SA}$ generated oxidative stress without nitrosative stress and induced an acclimation process during normal photoperiod or prolonged darkness in WT plants.

3. The relative importance of arginine decarboxylase (ADC) and ornithine decarboxylase (ODC) activities in putrescine (Put) biosynthesis was different at low and high SA because $O D C$ gene 
has not been induced by $0.1 \mathrm{mM}$ SA. However, $O D C$ was highly up-regulated by high concentration of SA suggesting that ADC is more important in Put biosynthesis during stress acclimation than ODC. It can be concluded that much higher induction occurred after lethal SA treatment in SIADC, SIODC and spermine synthase (SISPMS) expression than after sublethal one, but the expression of spermidine synthase (SISPDS) has not been changed significantly with increasing SA concentrations. The expression pattern of the PA biosynthetic genes correlated well with the PAs accumulation. Thus, it can be concluded that PA biosynthesis exerts a significant control over PA level in the first $24 \mathrm{~h}$ of SA treatment.

4. $0.1 \mathrm{mM}$ SA induced DAO activity and the expression of SIDAO1 and SIDAO2 both in the light and dark, nevertheless $1 \mathrm{mM}$ SA caused much lower induction and significant changes occurred only in the dark and not in the light. The expression of SIPAO1 at both SA concentrations was significantly higher in the dark after $6 \mathrm{~h}$ than in control plants but this was not correlated with the terminal oxidation of higher PAs. Moreover, we did not find strict temporal coincidence between $\mathrm{H}_{2} \mathrm{O}_{2}$ accumulation and PA catabolism. This means that ROS production by other processes at $1 \mathrm{mM} \mathrm{SA}$ can overrun ROS generated by terminal oxidation of PAs in actively photosynthesizing tissues.

5. The NADPH oxidase activity, which is responsible for the fast accumulation of superoxide anion radical, was induced by $1 \mathrm{mM}$ SA within an hour under normal photoperiod. The expression of the chloroplastic superoxide dismutase $(\mathrm{Cu} / \mathrm{Zn}-\mathrm{SOD})$ and mitochondrial $\mathrm{Mn}-\mathrm{SOD}$ coding genes were increased by $1 \mathrm{mM}$ SA treatment in the light samples while there were no major changes at $0.1 \mathrm{mM}$ SA. These suggest that the oxidative stress may activate the expression of chloroplastic $\mathrm{Cu} / \mathrm{Zn}$-SOD and mitochondrial Mn-SOD. However, the enzyme activities correlated only slightly with the changes in gene expression. Interestingly, both SA treatments inhibited the activity of catalase (CAT) enzyme, which was independent of the illumination. The other $\mathrm{H}_{2} \mathrm{O}_{2}$ scavenging enzyme, ascorbate peroxidase (APX) exhibited the highest light-dependency after SA treatments. In the first hours APX activity was inhibited by $1 \mathrm{mM} \mathrm{SA}$, which can contribute in parallel with the inhibition of CAT activity to the first peak of $\mathrm{H}_{2} \mathrm{O}_{2}$ accumulation. In contrast to APX, guaiacol peroxidase (POD) activity increased upon $1 \mathrm{mM}$ SA treatment later under both environments. Thus, POD activity can contribute to the decomposition of $\mathrm{H}_{2} \mathrm{O}_{2}$ in the dark, which is particularly important in the absence of CAT and APX activity in SA-mediated protective actions.

6. SA-induced increases in $\mathrm{H}_{2} \mathrm{O}_{2}$ were also observed in $\mathrm{Nr}$ plants. The most interesting tendencies could be detected at $1 \mathrm{mM}$ SA concentration. While the inhibition of ET signalling by the $\mathrm{Nr}$ mutation decreased the SA-induced $\mathrm{H}_{2} \mathrm{O}_{2}$ content, EL and necrotic lesions on the leaves in the light compared to WT, but it resulted in pronounced $\mathrm{H}_{2} \mathrm{O}_{2}$ accumulation, increased EL and 
higher necrotic lesions under prolonged darkness. This suggests that not only SA and ET levels but also their signalling pathways are dependent on the presence or absence of light. This suggests that the $\mathrm{Nr}$ mutants were more tolerant to SA-induced oxidative stress than WT in normal photoperiod but they proved to be more sensitive during prolonged darkness.

7. Exogenous application of SA had a concentration dependent impact on PA contents in WT under light and dark conditions, which was most pronounced for spermine (Spm) content in $1 \mathrm{mM}$ SA treatment under light and for Put concentration in $1 \mathrm{mM}$ SA treatment under dark condition. On the other hand, PAs concentration was higher in WT compared to $\mathrm{Nr}$ after both SA treatments under light and dark conditions. The lack of active in ET signalling could decrease free PAs content by the inhibition of PA biosynthetic genes expression, which was most pronounced in case of SISPMS. Furthermore, decreased PA contents may contribute to SA-induced cell death in the leaves of $N r$ plants.

8. $N r$ leaf exhibited almost always higher DAO and PAO activities compared with WT even in control conditions. If $\mathrm{Nr}$ plants were treated with $1 \mathrm{mM} \mathrm{SA}, \mathrm{DAO}$ activity increased and PAO activity decreased under normal photoperiod, but under darkness, activity of both enzymes increased significantly compared to $\mathrm{Nr}$ control. In our experiments DAO and PAO activity showed strict correlation with PAs content. The increased activities of terminal catabolic enzyme may play a role in increased inter-/intracellular levels of $\mathrm{ROS}\left(\mathrm{H}_{2} \mathrm{O}_{2}\right.$ and $\left.\mathrm{O}_{2}{ }^{-}\right)$under darkness in the $N r$ leaves.

9. The $\mathrm{H}_{2} \mathrm{O}_{2}$ accumulation in WT leaves in response to $1 \mathrm{mM}$ SA treatment is mainly determined by increased SOD and decreased CAT activities in the light, thus APX and POD proved to be main participants in $\mathrm{H}_{2} \mathrm{O}_{2}$ scavenging. In contrast, in a prolonged dark period the SOD activity and the expression of $S l C u / Z n S O D$ gene were activated in $\mathrm{Nr}$ mutants exposed to $1 \mathrm{mM}$ SA but the absence of APX and POD activation led to a significant accumulation of $\mathrm{H}_{2} \mathrm{O}_{2}$ in these samples. These results suggest that the SA-induced $\mathrm{H}_{2} \mathrm{O}_{2}$ metabolism is regulated by different enzymes in WT and ET signalling mutant plants, which is modified by the presence or absence of light. 


\section{Irodalomjegyzék}

Agarwal S., Sairam R.K., Srivastava G.C., Tyagi A., Meena R.C. (2005) Role of ABA, salicylic acid, calcium and hydrogen peroxide on antioxidant enzymes induction in wheat seedlings. Plant Sci. 169(3): 559-570.

Agudelo-Romero P., Bortolloti C., Pais M.S., Tiburcio A.F., Fortes A.M. (2013) Study of polyamines during grape ripening indicate an important role of polyamine catabolism. Plant Physiol. Biochem. 67: 105-119.

Alcázar R., Altabella T., Marco F., Bortolotti C., Reymond M., Koncz C., és mtsai. (2010) Polyamines: molecules with regulatory functions in plant abiotic stress tolerance. Planta 231: 1237-1249.

Alcázar R., Garcia-Martinez J.L., Cuevas J.C., Tiburcio A.F., Altabella T. (2005) Overexpression of $A D C 2$ in Arabidopsis induces dwarfism and late-flowering through GA deficiency. Plant J. 43: 425436.

Alscher R.G., Erturk N., Heath L.S. (2002) Role of superoxide dismutases (SODs) in controlling oxidative stress in plants. Journal of experimental botany. 53(372): 1331-1341.

Ananieva E.A., Christov K.N., Popova L.P. (2004) Exogenous treatment with salicylic acid leads to increased antioxidant capacity in leaves of barley plants exposed to paraquat. Journal of Plant Physiology. 161: 319-328.

Andronis E.A., Moschou P.N., Toumi I., Roubelakis-Angelakis K.A. (2014) Peroxisomal polyamine oxidase and NADPH-oxidase cross-talk for ROS homeostasis which affects respiration rate in Arabidopsis thaliana. Front. Plant Sci. 5: 132.

Anwar R., Mattoo A., Handa A. (2015) Polyamine interactions with plant hormones: crosstalk at several levels. in Kusano T, Suzuki H (eds). Polyamines a Universal Molecular Nexus for Growth, Survival and Specialized Metabolism. Tokyo: Springer. pp 267-303.

Apparao Kolla V., Raghavendra A.S. (2007) Nitric oxide is a signaling intermediate during bicarbonateinduced stomatal closure in Pisum sativum. Physiol. Plant. 130: 91-98.

Arasimowicz-Jelonek M., Floryszak-Wieczorek J., Abramowski D., Izbianska K. (2014) Nitric oxide and reactive nitrogen species. Nitric oxide in plants: Metabolism and role in stress physiology pp 165-184.

Arasimowicz-Jelonek M., Floryszak-Wieczorek J., Kubiś J. (2009) Interaction between polyamine and nitric oxide signaling in adaptive responses to drought in cucumber. J. Plant Growth Regul. 28: 17786.

Aro E.M., Suorsa M., Rokka A., Allahverdiyeva Y., Paakkarinen V., Saleem A., Battchikova N., Rintamaki E. (2005) Dynamics of photosystem II: A proteomic approach to thylakoid protein complexes. J. Exp. Bot. 56: 347-356.

Asada K. (1997) The role of ascorbate peroxidase and monodehydroascorbate reductase in $\mathrm{H}_{2} \mathrm{O}_{2}$ scavenging in plants. Cold Spring Harbor Monograph Archive. 34: 715-735.

Asada K. (2006) Production and scavenging of reactive oxygen species in chloroplasts and their functions. Plant Physiol. 141: 391-396.

Astier J., Kulik A., Koen E., Besson-Bard A., Bourque S., Jeandroz S., Lamotte O., Wendehenne D. (2012) Protein S-nitrosylation: What's going on in plants? Free Rad Biol Med 53: 1101-1110.

Astier J., Lindermayr C. (2012) Nitric oxide-dependent posttranslational modification in plants: an update. Int J Mol Sci. 13: 15193-15208.

Athwal G.S., Huber S.C. (2002) Divalent cations and polyamines bind to loop 8 of 14-3-3 proteins, modulating their interaction with phosphorylated nitrate reductase. Plant J. 29: 119-129.

Attia H., Karray N., Lachaâl M. (2009) Light interacts with salt stress in regulating superoxide dismutase gene expression in Arabidopsis. Plant Sci. 177(3): 161-167.

Bali S., Poonam, Gautam V., Kaur P., Khanna K., Kaur R., Vig A.P., Ohri P. (2017) Interaction of salicylic acid with plant hormones in plants under abiotic stress. Salicylic acid: A multifaceted hormone. 201-219.

Ballaré C.L. (2014) Light regulation of plant defense. Annu. Rev. Plant Biol. 65: 335-363.

Bartels S., Anderson J.C., Gonzalez Besteiro M.A., Carreri A., Hirt H., Buchala A., Metraux J.P., Pech S.C., Ulm R. (2009) MAP KINASE PHOSPHATASE1 and PROTEIN TYROSINE PHOSPHATASE1 are repressors of salicylic acid synthesis and SNC1-mediated responses in Arabidopsis. Plant Cell. 21: 2884-2897. 
Bassi P.K., Spencer M.S. (1983) Does light inhibit ethylene production in leaves? Plant Physiology. 73: 758-760.

Bayer E.M., Bottrill A.R., Walshaw J., Vigouroux M., Naldrett M.J., Thomas C.L., és mtsai., (2006) Arabidopsis cell wall proteome defined using multidimensional protein identification technology. Proteomics. 6: 301-311.

Begara-Morales J.C., Sánchez-Calvo M., Chaki és mtsai. (2014) Dual regulation of cytosolic ascorbate peroxidase (APX) by tyrosine nitration and S-nitrosylation. Journal of Experimental Botany. 65: 527-538.

Belda-Palazón B., Ruiz L., Martí E., Tárraga S., Tiburcio A.F., Culiáñez F., és mtsai. (2012) Aminopropyltransferases involved in polyamine biosynthesis localize preferentially in the nucleus of plant cells. PLOS ONE. 7: e46907.

Bellin D., Asai S., Delledonne M., Yoshioka H. (2013) Nitric oxide as a mediator for defense responses. Mol Plant Microbe Interact. 26: 271-277.

Biswas M.S., Mano J. (2015) Lipid peroxide-derived short-chain carbonyls mediate $\mathrm{H}_{2} \mathrm{O}_{2}$-induced and $\mathrm{NaCl}$-induced programmed cell death in plants. Plant Physiol. 168: 885-898.

Bortolotti C., Cordeiro A., Alcázar R., Borrell A., Culiañez-Macià F.A., Tiburcio A.F., és mtsai (2004) Localization of arginine decarboxylase in tobacco plants. Physiol. Plant. 120: 84-92.

Bradford M.M. (1976) A rapid and sensitive method for the quantification of microgram quantities of protein utilizing the principle of protein-dye binding. Anal. Biochem. 72: 248-254.

Bright J., Desikan R., Hancock J.T., Weir J.S., Neill S.J. (2006) ABA-induced NO generation and stomatal closure in Arabidopsis are dependent on $\mathrm{H}_{2} \mathrm{O}_{2}$ synthesis. Plant J. 45: 113-122.

Broekgaarden C., Caarls L., Vos I.A., Pieterse C.M., Van Wees S.C. (2015) Ethylene: traffic controller on hormonal crossroads to defense. Plant physiology. 169(4): 2371-2379.

Bulens I., Van de Poel B., Hertog M.L., Cristescu S.M., Harren F.J., De Proft M.P., és mtsai., (2014) Dynamic changes of the ethylene biosynthesis in 'Jonagold' apple. Physiologia Plantarum. 150: 161-173.

Camejo D., Martí M.D.C., Nicolás E., Alarcón J.J., Jiménez A., Sevilla F. (2007) Response of superoxide dismutase isoenzymes in tomato plants (Lycopersicon esculentum) during thermoacclimation of the photosynthetic apparatus. Physiologia Plantarum. 131: 367-377.

Carter C., Healy R., O'Tool N.M., Naqvi S.M.S., Ren G., Park S., Beattie G.A., Horner H.T., Thronburg R.W. (2007) Tobacco nectarines express a novel NADPH oxidase implicated in the defense of floral reproductive tissues against microorganisms. Plant Physiol. 143: 389-399.

Cassol T., Mattoo A.K. (2003) Do polyamines and ethylene interact to regulate plant growth, development and senescence? In: Nath P, Mattoo AK, Panade SR, Weil JH (eds) Molecular insights in plant biology. Science Publishers, Enfield, pp 121-132.

Caverzan A., Casassola A., és Brammer S. P. (2016) Reactive oxygen species and antioxidant enzymes involved in plant tolerance to stress. Abiotic and Biotic Stress in Plants-Recent Advances and Future Perspectives, ed. A. Shanker (Rijeka: InTech).

Caverzan A., Passaia G., Rosa S.B., Ribeiro C.W., Lazzarotto F., Margis-Pinheiro M. (2012) Plant responses to stresses: role of ascorbate peroxidase in the antioxidant protection. Genet. Mol. Biol. 35: 1011-1019.

Cervelli M., Cona A., Angelini R., Polticelli F., Federico R., Mariottini P. (2001) A barley polyamine oxidase isoform with distinct structural features and subcellular localization. Eur. J. Biochem. 268: 3816-3830.

Cervelli M., Tavladoraki P., Di Agostino S., Angelini R., Federico R., Mariottini P. (2000) Isolation and characterization of three polyamine oxidase genes from Zea mays. Plant Physiol. Biochem. 38: 667677.

Chandra-Shekara A.C., Gupte M., Navarre D., Raina S., Raina R., Klessig D., Kachroo P. (2006) Lightdependent hypersensitive response and resistance signaling against Turnip Crincle Virus in Arabidopsis. Plant J. 45: 320-334.

Chen Y.E., Cui J.M., Li G.X., Yuan M., Zhang Z.W., Yuan S., Zhang H.Y. (2016) Effect of salicylic acid on the antioxidant system and photosystem II in wheat seedlings. Biol. Plantarum. 60(1): 139147.

Chen Y.F., Gao Z., Kerris R.J., Wang W., Binder B.M., Schaller G.E. (2010) Ethylene receptors function as components of high-molecular-mass protein complexes in Arabidopsis. PLoS One. 5: 8640. 
Chen Z., Zheng Z., Huang J., Lai Z., Fan B. (2009) Biosynthesis of salicylic acid in plants. Plant Signaling and Behavior. 4: 493-496.

Cheng D.D., Liu M.J., Sun X.B., Zhao M., Chow W.S., Sun G.Y., Zhang Z.S., Hu Y.B. (2016) Light suppresses bacterial population through the accumulation of hydrogen peroxide in tobacco leaves infected with Pseudomonas syringae pv. tabaci. Front Plant Sci. 7: 512.

Cheng L., Ma F. (2004) Diurnal operation of the xanthophyll cycle and the antioxidant system in apple peel. Journal of the American Society for Horticultural Science. 129(3): 313-320.

Cheng M.C., Liao P.M., Kuo W.W., Lin T.P. (2013) The Arabidopsis ETHYLENE RESPONSE FACTOR1 regulates abiotic stress-responsive gene expression by binding to different cis-acting elements in response to different stress signals. Plant Physiol. 162: 1566-1582.

Choudhury S., Panda P., Sahoo L., Panda S.K. (2013) Reactive oxygen species signaling in plants under abiotic stress. Plant Signal. Behav. 8: 23681.

Choudhury S., Panda S.K. (2004) Role of salicylic acid in regulating cadmium induced oxidative stress in Oryza sativa L. roots. Bulg. J. Plant Physiol. 30: 95-110.

Christie J.M., Blackwood L.M., Petersen J., Sullivan S. (2014) Plant flavoprotein photoreceptors. Plant Cell Physiol. 56: 401-413.

Cohen M.F., Gurung S., Fukuto J.M., Yamasaki H. (2014) Controlled free radical attack in the apoplast: a hypothesis for roles of $\mathrm{O}, \mathrm{N}$ and $\mathrm{S}$ species in regulatory and polysaccharide cleavage events during rapid abscission by Azolla. Plant Sci. 217: 120-126.

Coll N.S., Epple P., Dangl J.L. (2011) Programmed cell death in the plant immune system. Cell Death Differ. 18: 1247-1256.

Cona A., Cenci F., Cervelli M., Federico R., Marottini P., Moreno S., Angelini R. (2003) Polyamine Oxidase, a hydrogen peroxide-producing enzyme, is up-regulated by light and down-regulated by auxin in the outer tissues of the maize mesocotyl. Plant Physiol. 131: 803-813.

Cona A., Rea G., Angelini R., Federico R., Tavladoraki P. (2006) Functions of amine oxidase in plant development and defence. Trends in Plants Sci. 11: 80-88.

Corpas F.J., Barroso J.B., Carreras A., Quirós M., León A.M., Romero-Puertas M.C., Esteban F.J., Valderrama R., Palma J.M., Sandalio L.M., Gómez M., del Río L.A. (2004) Cellular and subcellular localization of endogenous nitric oxide in young and senescent pea plants. Plant Physiol. 136: 27222733.

Corpas F.J., Palma J.M., del Río L.A., Barroso J.B. (2013) Protein tyrosine nitration in higher plants grown under natural and stress conditions. Frontiers in Plant Science. 4: 29.

Crous K.Y., Zaragoza-Castells J., Ellsworth D.S., Duursma R.A., Loew M., Tissue D. T., és mtsai. (2012) Light inhibition of leaf respiration in field-grown Eucalyptus saligna in whole-tree chambers under elevated atmospheric $\mathrm{CO}_{2}$ and summer drought. Plant Cell Environ. 35: 966-981.

Das K., Roychoudhury A. (2014) Reactive oxygen species (ROS) and response of antioxidants as ROSscavengers during environmental stress in plants. Front. Environ. Sci. 2: 53.

De Frenne P., Rodríguez-Sánchez F., De Schrijver A., Coomes D.A., Hermy M., Vangansbeke P., és mtsai., (2015) Light accelerates plant responses to warming. Nature Plants. 1: 15110.

De Jong A.J., Yakimova E.T., Kapcina V.M., Woltering E.J. (2002) A critical role of ethylene in hydrogen peroxide release during programmed cell death in tomato suspension cells. Planta. 214: 537-545.

De Pinto M.C., Locato V., De Gara L. (2012) Redox regulation in plant programmed cell death. Plant Cell Enviro. 35: 234-244.

Dean J.V., Mohammed L.A., Fitzpatrick T. (2005) The formation, vacuolar localization, and tonoplast transport of salicylic acid glucose conjugates in tobacco cell suspension cultures. Planta. 221: 287296.

Del Río L.A., Sandalio L.M., Corpas F.J., Palma J.M., Barroso J.B. (2006) Reactive oxygen species and reactive nitrogen species in peroxisomes. Production, scavenging, and role in cell signaling. Plant Physiol. 141: 330-335.

Delprato M.L., Krapp A.R., Carrillo N. (2015) Green light to plant responses to pathogens: the role of chloroplast light-dependent signaling in biotic stress. Photochem. Photobiol. 91: 1004-1011.

Dempsey D.A., Klessig D.F. (2017) How does the multifaceted plant hormone salicylic acid combat disease in plants and are similar mechanisms utilized in humans? BMC Biol. 15: 23.

Dong X. (1998) SA, JA, ethylene, and disease resistance in plants. Curr. Opin. Plant Biol. 1: 316-323. 
Dutilleul C., Garmier M., Noctor G., Mathieu C., Chétrit P., Foyer C.H., de Paepe R. (2003) Leaf mitochondria modulate whole cell redox homeostasis, set antioxidant capacity, and determine stress resistance through altered signaling and diurnal regulation. The Plant Cell. 15(5): 1212-1226.

Enyedi A.J., Yalpani N., Silverman P., Raskin I. (1992) Localization, conjugation, and function of salicylic acid in tobacco during the hypersensitive reaction to tobacco mosaic virus. Proc. Natl. Acad. Sci. USA. 89: 2480-2484.

Fan H.F., Du C.X., Guo S.R. (2010) Nitric oxide enhances salt tolerance in cucumber seedlings by regulating free polyamine content. Environmental and Experimental Botany. 86: 52-59.

Feigl G., Lehotia N., Molnár A., Ordog A., Rodríguez-Ruiz M., Palma J.M., et al. (2014) Zinc induces distinct changes in the metabolism of reactive oxygen and nitrogen species (ROS and RNS) in the roots of two Brassica species with different sensitivity to zinc stress. Ann. Bot. 116: 613-625.

Feng K., Yu J., Cheng Y., Ruan M., Wang R., Ye Q. és mtsai., (2016) The SOD gene family in tomato: identification, phylogenetic relationship and expression patterns. Fron. Plant. Sci. 30: 1279.

Fincato P., Moschou P.N., Spedaletti V., Tavazza R., Angelini R., Federico R., és mtsai. (2011) Functional diversity inside the Arabidopsis polyamine oxidase gene family. J. Exp. Bot. 62: 11551168.

Finlayson S.A., Lee I.J., Morgan P.W. (1998) Phytochrome B and the regulation of circadian ethylene production in sorghum. Plant Physiology. 116: 17-25.

Fobert P.R., Despres C. (2005) Redox control of systemic acquired resistance. Curr. Opin. Plant Biol. 8: $378-382$.

Foyer C.H., Noctor G. (2009) Redox regulation in photosynthetic organisms: signaling, acclimation, and practical implications. Antioxidants \& redox signaling. 11(4): 861-905.

Freschi L. (2013) Nitric oxide and phytohormone interactions: current status and perspectives. Front. Plant Sci. 4: 398.

Fuell C., Elliott K.A., Hanfrey C.C., Franceschetti M., Michael A.J. (2010) Polyamine biosynthetic diversity in plants and algae. Plant Physiology and Biochemistry. 48: 513-520.

Fujita M., Shinozaki K. (2015) Polyamine transport systems in plants. in: Kusano T., Suzuki H. (Eds.), Polyamines. Springer, Japan, pp. 179-185.

Gaffney T., Friedrich L., Vernooij B., Negrotto D., Nye G., Uknes S., Ward E., Kessmann H., Ryals J. (1993) Requirement of salicylic acid for the induction of systemic acquired resistance. Science. 261: 754-756.

Gallé Á. (2010) Búzafajták ozmotikus-és szárazságstressz alatti akklimatizációja, a glutation transzferázok szerepe a stresszválaszban. Doktori $(\mathrm{PhD})$ értekezés, Szegedi Tudományegyetem.

Garcion C., Metraux J.P. (2006) Salicylic acid. In: Hedden P, Thomas S. eds. Plant hormone signaling. Harpenden, Blackwell Publishing, 229-256.

Garufi A., Visconti S., Camoni L., Aducci P. (2007) Polyamines as physiological regulators of 14-3-3 interaction with the plant plasma membrane $\mathrm{H}^{+}$-ATPase. Plant and Cell Physiology. 48: 434-440.

Gémes K., Poór P., Horváth E., Kolbert Zs., Szopkó D., Szepesi Á., Tari I. (2011) Cross-talk between salicylic acid and $\mathrm{NaCl}$-generated reactive oxygen species and nitric oxide in tomato during acclimation to high salinity. Physiol. Plant. 142: 179-192.

Gemperlova L., Novákova M., Vanková R., Eder J., Cvikrova M. (2006) Diurnal changes in polyamine content, arginine and ornithine decarboxylase, and diamine oxidase in tobacco leaves. Journal of Experimental Botany. 57: 1413-1421.

Genoud T., Buchala A.J., Chua N.H., Métraux J.P. (2002) Phytochrome signalling modulates the SAperceptive pathway in Arabidopsis. Plant J. 31: 87-95.

Gharbi E., Martínez J.P., Benahmed H., Fauconnier M.L., Lutts S., Quinet M. (2016) Salicylic acid differently impacts ethylene and polyamine synthesis in the glycophyte Solanum lycopersicum and the wild-related halophyte Solanum chilense exposed to mild salt stress. Physiol. Plantarum. 158(2): 152-167.

Glazebrook J. (2005) Contrasting mechanisms of defense against biotrophic and necrotrophic pathogens. Ann. Rev. Phytopathol. 43: 205-227.

Gohre V., Jones A.M.E., Sklenar J., Robatzek S., Weber A.P.M. (2012) Molecular crosstalk between PAMP-triggered immunity and photosynthesis. Mol Plant Microbe Interact. 25: 1083-1092.

Gonzalez M.E., Marco F., Minguet E.G., Carrasco-Sorli P., Blázquez M.A., Carbonell J., Ruiz O.A., Pieckenstain F.L. (2011) Perturbation of spermine synthase gene expression and transcript profiling provide new insights on the role of the tetraamine spermine in Arabidopsis defense against Pseudomonas viridiflava. Plant Physiol. 156: 2266-2277. 
Griebel T., Zeier J. (2008) Light regulation and daytime dependency of inducable plant defenses in Arabidopsis: Phytochrome signaling controls systemic acquired resistance rather than local defense. Plant Physiol. 147: 790-801.

Groppa M.D., Benavides M.P. (2008) Polyamines and abiotic stress: recent advances. Amino Acids. 34: $35-45$.

Groß F., Rudolf E.E., Thiele B., Durner J., Astier J. (2017) Copper amine oxidase 8 regulates argininedependent nitric oxide production in Arabidopis thaliana. J. Exp. Bot. 68: 2149-2162.

Grün S., Lindermayr C., Sell S., Durner J. (2006) Nitric oxide and gene regulation in plants. J. Exp. Bot. 57: 507-516.

Guerrero-González M.L., Rodriguez-Kessler M., Jimenez-Bremont J.F. (2014) uORF, a regulatory mechanism of the Arabidopsis polyamine oxidase 2. Mol.Biol.Rep. 41: 2427-2443.

Gupta K., Dey A., Gupta B. (2013) Plant polyamines in abiotic stress responses. Acta Physiologiae Plantarum. 35: 2015-2036.

Gupta K.J., Igamberdiev A.U. (2016) Reactive nitrogen species in mitochondria and their implications in plant energy status and hypoxic stress tolerance. Frontiers in Plant Science. 7: 369.

Gust A.A., Nurnberger T. (2012) Plant immunology: A life or death switch. Nature. 486: 198-199.

Han C., Zuo J., Wang Q., Xu L., Wang Z., Dong H., Gao L. (2015) Effects of 1-MCP on postharvest physiology and quality of bitter melon (Momordica charantia L.). Scientia Horticulturae. 182: 8691

Han Y., Chaouch S., Mhamdi A., Queval G., Zechmann B., Noctor G.D. (2012) Functional analysis of Arabidopsis mutants points to novel roles for glutathione in coupling $\mathrm{H}_{2} \mathrm{O}_{2}$ to activation of salicylic acid accumulation and signaling. Antioxidants and Redox Signaling. 18: 2106-2121.

Harindra Champa W.A., Gilla M.I.S., Mahajanb B.V.C., Bedic S. (2015) Exogenous treatment of spermine to maintain quality and extend postharvest life of table grapes (Vitis vinifera L.) cv. Flame Seedless under low temperature storage. LWT Food Sci. Technol. 60: 412-419.

Harpaz-Saad S., Yoon G.M., Mattoo A.K., Kieber J.J. (2012) The formation of ACC and competition between polyamines and ethylene for SAM. Annu Plant Rev. 44: 53-81.

Hayat Q., Hayat S., Irfan M., Ahmad A. (2010) Effect of exogenous salicylic acid under changing environment: A review. Environ. Exp. Bot. 68: 14-25.

Herrera-Vásquez A., Salinas P., Holuigue L. (2015) Salicylic acid and reactive oxygen species interplay in the transcriptional control of defense genes expression. Front. Plant Sci. 6: 171.

Hideg E., Barta C., Kalai T., Vass M., Hideg K., Asada K. (2002) Detection of singlet oxygen and superoxide with fluorescence sensors in leaves under stress by photoinhibition or UV radiation. Plant Cell Physiol. 43: 1154-1164.

Horváth E., Csiszár J., Gallé Á., Poór P., Szepesi Á., Tari I. (2015) Hardening with salicylic acid induces concentration-dependent changes in abscisic acid biosynthesis of tomato under salt stress. $J$. Plant Physiol. 183: 54-63.

Horváth E., Szalai G., Janda T. (2007) Induction of abiotic stress tolerance by salicylic acid signaling. $J$. Plant Growth Regul. 26: 290-300.

Hou Z.H., Liu G.H., Hou L.,X., Wang L.X., Liu X. (2013) Regulatory function of polyamine oxidasegenerated hydrogen peroxide in ethylene-induced stomatal closure in Arabidopsis thaliana. J. Integr. Agric. 12: 251-262.

Hu X., Zhang Y., Shi Y., Zhang Z., Zou Z., Zhang H., Zhao J. (2012) Effect of exogenous spermidine on polyamine content and metabolism in tomato exposed to salinity-alkalinity mixed stress. Plant Physiol Biochem. 57: 200-209.

Hua J. (2013) Modulation of plant immunity by light, circadian rhythm, and temperature. Curr. Opin. Plant Biol. 16: 406-413.

Hummel I., Bourdais G., Gouesbet G., Couée I., Malmberg R.L., Amrani A.E. (2001) Differential gene expression of arginin decarboxylase $A D C 1$ and $A D C 2$ in Arabidopsis thaliana: characterization of transcriptional regulation during seed germination and seedling development. New Phytol. 163: 519531.

Hussain S.S., Ali M., Ahmad M., Siddique K.H.M. (2011) Polyamines: natural and engineered abiotic and biotic stress tolerance in plants. Biotechnol. Adv. 29: 300-311.

Imai A., Matsuyama T., Hanzawa Y., Akiyama T., Tamaoki M., Saji H., Shirano Y., Kato T., Hayashi H., Shibata D., Tabata S., Komeda Y., Takahashi T. (2004a) Spermidine synthase genes are essential for survival of Arabidopsis. Plant Physiol. 135: 1565-1573. 
Imai A., Akiyama T., Kato T., Sato S., Tabata S., Yamamoto K.T., Takahashi T. (2004b) Spermine is not essential for survival of Arabidopsis. FEBS Lett. 556: 148-152.

Iqbal M., Ashraf M. (2006) Wheat seed priming in relation to salt tolerance: growth, yieldandlevels offree salicylic acidandpolyamines. Ann. Bot. Fenn. 43: 250-259.

Janda K., Hideg É., Szalai G., Kovács L., Janda T. (2012) Salicylic acid may indirectly influence the photosynthetic electron transport. J. Plant Physiol. 169: 971-978.

Janda M., Ruelland E. (2015) Magical mystery tour: Salicylic acid signaling. Environ Exp Bot. 114: $117-28$.

Janda T., Gondor O. K., Yordanova R., Szalai G., Pál M. (2014) Salicylic acid and photosynthesis: signalling and effects. Acta physiologiae plantarum. 36(10): 2537-2546.

Janda T., Szalai G., Rios-Gonzalez K., Veisz O., Paldi E. (2003) Comparative study of frost tolerance and antioxidant activity in cereals. Plant Sci. 164: 301-306.

Janda T., Szalai G., Tari I., Páldi E. (1999) Hydroponic treatment with salicylic acid decreases the effects of chilling injury in maize (Zea mays L.). Planta. 208: 175-180.

Jang E.K., Min K.H., Kim S.H., Nam S.H., Zhang S., Kim Y.C. és mtsai., (2009) Mitogen-activated protein kinase cascade in the signaling for polyamine biosynthesis in tobacco. Plant Cell Physiol. 50: 658-664.

Jaskiewicz M., Conrath U., Peterhansel C. (2011) Chromatin modification acts as a memory for systemic acquired resistance in the plant stress response. EMBO Rep. 12: 50-55.

Jeandroz S., Wipf D., Stuehr D.J., Lamattina L., Melkonian M., Tian Z., Zhu Y.,, Carpenter E.J., Wong G.K., Wendehenne D. (2016) Occurrence, structure, and evolution of nitric oxide synthase-like proteins in the plant kingdom. Sci. Signal. 9: 417.

Ji Y., Guo H. (2013) From endoplasmic reticulum (ER) to nucleus: EIN2 bridges the gap in ethylene signaling. Mol Plant. 6: 11-14.

Jiménez-Bremont J.F., Marina M., de la Luz Guerrero-González M., Rossi F.R., Sánchez-Rangel D., Rodríguez-Kessler M., Ruiz O.A., Gárriz A. (2014) Physiological and molecular implications of plant polyamine metabolism during biotic interactions. Front. Plant. Sci. 5: 95.

Joo J., Lee Y.H., Song S.I. (2014) Rice CatA, CatB, and CatC are involved in environmental stress response, root growth, and photorespiration, respectively. Journal of Plant Biology. 57(6): 375-382.

Joo J.H., Wang S., Chen J.G., Jones A.M., Fedoroff N.V. (2005) Different signaling and cell death roles of heterotrimeric $\mathrm{G}$ protein $\mathrm{a}$ and $\mathrm{b}$ subunits in the Arabidopsis oxidative stress response to ozone. Plant Cell. 17: 957-970.

Ju C.L., Yoon G.M., Shemansky J.M., Lin D.Y., Ying Z.I., Chang J.H., Garrett W.M., Kessenbrock M., Groth G., Tucker M.L., Cooper B., Kieber J.J., Chang C. (2012) CTR1 phosphorylates the central regulator EIN2 to control ethylene hormone signaling from the ER membrane to the nucleus in Arabidopsis. Proc. Natl. Acad. Sci. USA. 109: 19486-19491.

Kanazawa S., San S., Koshiba T., Ushimaru T. (2000) Changes in antioxidative enzymes in cucumber cotyledons during natural senescence: comparison with those during dark-induced senescence. Physiologia Plantarum. 109: 211-216.

Kangasjärvi S., Neukermans J., Li S., Aro E.M., Noctor G. (2012) Photosynthesis, photorespiration, and light signalling in defence responses. J. Exp. Bot. 63: 1619-1636.

Kärkönen A., Kuchitsu K. (2015) Reactive oxygen species in cell wall metabolism and development in plants. Phytochemistry. 112: 22-32.

Karpiński S., Gabrys H., Mateo A., Karpinska B., Mullineaux P.M. (2003) Light perception in plant disease defence signalling. Curr. Opin. Plant Biol. 6: 390-396.

Karpiński S., Szechyńska-Hebda M., Wituszińska W., Burdiak P. (2013) Light acclimation, retrograde signalling, cell death and immune defences in plants. Plant, Cell Environ. 36: 736-744.

Kato H., Takemoto D., Kawakita K. (2012) Proteomic analysis of S-nitrosylated proteins in potato plant. Physiol. Plant. 148: 371-386.

Kerdnaimongkol K., Bhatia A., Joly R.J., Woodson W.R. (1997) Oxidative stress and diurnal variation in chilling sensitivity of tomato seedlings. J. Am. Soc. Hortic. Sci. 122: 485-490.

Khan M.I.R., Fatma M., Per T.S., Anjum N.A., Khan N.A. (2015) Salicylic acid-induced abiotic stress tolerance and underlying mechanisms in plants. Front. Plant. Sci. 6: 462.

Khokon M.D.A.R., Okuma E., Hossain M.A., Munemasa S., Uraji M., Nakamura Y., Mori I.C., Murata Y. (2011) Involvement of extracellular oxidative burst in salicylic acid-induced stomatal closure in Arabidopsis. Plant Cell Environ. 34: 434-443. 
Kim N.H., Kim B.S., Hwang B.K. (2013) Pepper arginine decarboxylase is required for polyamine and gamma-aminobutyric acid signaling in cell death and defense response. Plant Physiol. 162: 20672083.

Kim Y.H., Park C.S., Ji Y.C., Lee J.J., Jeong C.J., Lee S.H., Kwak S.S. (2015) Diverse antioxidant enzyme levels in different sweet potato root types during storage root formation. Plant Growth Reg. 75: $155-164$.

Klee H., Tieman D. (2002) The tomato ethylene receptor gene family: form and function. Physiol Plant. 115: 336-341.

Knörzer O.C., Lederer B., Durner J., Böger P. (1999) Antioxidant defense activation in soybean cells. Physiol. Plant. 107: 294-302.

Kocsy G., Tari I., Vanková R., Zechmann B., Gulyás Z., Poór P., Galiba G. (2013) Redox control of plant growth and development. Plant Science. 211: 77-91.

Koornneef A., Pieterse C.M. (2008) Cross talk in defense signaling. Plant physiology. 146(3): 839-844.

Krantev A., Yordanova R., Janda T., Szalai G., Popova L. (2008) Treatment with salicylic acid decreases the effect of cadmium on photosynthesis in maize plants. J. Plant Physiol. 165: 920-931.

Kubi J. (2005). The effect of exogenous spermidine on superoxide dismutase activity, $\mathrm{H}_{2} \mathrm{O}_{2}$ and superoxide radical level in barley leaves under water deficit conditions. Acta Physiol. Plant. 27: 289295.

Kubo A., Saji H., Tanaka K., Kondo N. (1995) Expression of Arabidopsis cytosolic ascorbate peroxidase gene in response to ozone or sulfur dioxide.Plant molecular biology. 29(3): 479-489.

Kuo W., Huang C., Shih C., Jinn T. (2013) Cellular extract preparation for superoxide dismutase (SOD) activity assay. Bio-protocol. 3: 811.

Kusano T., Berberich T., Tateda C., Takahashi Y. (2008) Polyamines: Essential factors for growth and survival. Planta. 228: $367-381$.

Kusano T., Suzuki H. (2015) Polyamines: A universal molecular nexus for growth, survival, and specialized metabolism. Springer.

Lamotte O., Bertoldo J.B., Besson-Bard A., Rosnoblet C., Aime S., Hichami S., Terenzi H., Wendehenne D. (2015) Protein S-nitrosylation: specificity and identification strategies in plants. Front. Chem. 2: 114.

Lanahan M.B., Yen H.C., Giovannoni J.J., Klee H.J. (1994) The never ripe mutation blocks ethylene perception in tomato. Plant Cell. 6: 521-530.

Larkindale J., Huang B. (2004) Thermotolerance and antioxidant systems in Agrostis stolonifera: involvement of salicylic acid, abscisic acid, calcium, hydrogen peroxide, and ethylene. J. Plant Physiol. 161: 405-413.

Leclerq J., Adams-Phillips L.C., Zegzouti H., Jones B., Latche A., Giovanni J.J., Pech J.C., Bouzayen M. (2002) LeCTR1, a tomato CTR1-like gene, demonstrates ethylene signaling ability in Arabidopsis and novel expression patterns in tomato. Plant Physiology. 130: 1132-1142.

Lee H., Léon J., Raskin I. (1995) Biosynthesis and metabolism of salicylic acid. Proc Natl Acad. Sci. USA. 92: 4076-4079.

Leon-Reyes A., Spoel S.H., De Lange E.S., Abe H., Kobayashi M., Tsuda S., Pieterse C.M. (2009) Ethylene modulates the role of NONEXPRESSOR OF PATHOGENESIS-RELATED GENES1 in cross talk between salicylate and jasmonate signaling. Plant Physiology. 149(4): 1797-1809.

Leslie C.A., Romani R.J. (1986) Salicylic acid: A new inhibitor of ethylene biosynthesis. Plant Cell Rep. 5: $144-146$.

Leslie C.A., Romani R.J. (1988) Inhibition of ethylene biosynthesis by salicylic acid. Plant Physiology. 88: 833-837.

Li C., Jiao J., Wang G. (2004) The important roles of reactive oxygen species in the relationship between ethylene and polyamines in leaves of spring wheat seedlings under root osmotic stress. Plant Sci. 166: 303-315.

Li S., Jin H., Zhang Q. (2016) The effect of exogenous spermidine concentration on polyamine metabolism and salt tolerance in Zoysia grass (Zoysia japonica Steud) subjected to short-term salinity stress. Front. Plant Sci. 7: 1221.

Li Z.G., Xie L.R., Li X.J. (2015a) Hydrogen sulfide acts as a downstream signal molecule in salicylic acid-induced heat tolerance in maize (Zea mays L.) seedlings. Journal of Plant Physiology. 177: 121-127. 
Li Z., Zhou H., Peng Y., Zhang X., Ma X., Huang L., Yan Y. (2015b) Exogenously applied spermidine improves drought tolerance in creeping bentgrass associated with changes in antioxidant defense, endogenous polyamines and phytohormones. Plant Growth Regul. 76: 71-82.

Lim P.O., Kim H.J., Gil Nam H. (2007) Leaf senescence. Annual Review of Plant Biology 58: 115-136.

Limones C.G., Hervás A., Navas-cortés J.A., Jiménez-Diaz R.M., Tena M. (2002) Induction of an antioxidant enzyme system and other oxidative stress markers associated with compatible and incompat- ible interactions between chickpea (Cicer arietinum L.) and Fusarium oxysporum f. sp. ciceris. Physiol. Mol. Plant Pathol. 61: 325-337.

Lin Y., Wang J., Zu Y., Tang Z. (2012) Ethylene antagonizes the inhibition of germination in Arabidopsis induced by salinity by modulating the concentration of hydrogen peroxide. Acta Physiol. Plant. 34: 1895-1904.

Lindermayr C., Saalbach G., Durner J. (2005) Proteomic identification of S-nitrosylated proteins in Arabidopsis. Plant Physiol. 137: 921-930.

Lindermayr C., Sell S., Müller B., Leister D., Durner J. (2010). Redox regulation of the NPR1-TGA1 system of Arabidopsis thaliana by nitric oxide. Plant Cell. 22: 2894-2907.

Liu J.H., Nada K., Honda C., Kitashiba H., Wen X.P., Pang X.M., és mtsai. (2006) Polyamine biosynthesis of apple callus under salt stress: importance of the arginine decarboxylase pathway in stress response. J. Exp. Bot. 57: 2589-2599.

Liu P.P., Dahl C.C., Klessig D.F., von Dahl C.C. (2011) The extent to which methyl salicylate is required for signaling systemic acquired resistance is dependent on exposure to light after infection. Plant Physiol. 157: 2216-2226.

Liu T., Kim D.W., Niitsu M., Maeda S., Watanabe S., Kamio Y., és mtsai., (2014) Polyamine oxidase 7 is a terminal catabolism-type enzyme in Oryza sativa and is specifically expressed in anthers. Plant Cell Physiol. 55: 1110-1122.

Livak K.J., Schmittgen T.D. (2001) Analysis of relative gene expression data using real-time quantitative PCR and the $2^{-\Delta \Delta \mathrm{Ct}}$ method. Methods. 25: 402-408.

Locato V., Paradiso A., Sabetta W., De Gara L., de Pinto M.C. (2016) Chapter nine-Nitric oxide and reactive oxygen species in PCD signalling. Adv. Bot. Res. 77: 165-192.

Lovdal T., Lillo C. (2009) Reference gene selection for quantitative real-time PCR normalization in tomato subjected to nitrogen, cold, and light stress. Analytical Biochemistry. 387: 238-242.

Lu S., Faris J.D., Sherwood R., Edwards M.C. (2013) Dimerization and protease resistance: new insight into the function of PR-1. J. Plant Physiol. 170: 105-110.

Luna C.M., Pastori G.M., Driscoll S., Groten K., Bernard S., Foyer C.H. (2005) Drought controls on $\mathrm{H}_{2} \mathrm{O}_{2}$ accumulation, catalase (CAT) activity and CAT gene expression in wheat. J. Exp. Bot. 56(411): 417-423.

Luo J.P., Jiang S.T., Pan L.J. (2001) Enhanced somatic embryogenesis by salicylic acid of Astragalus adsurgens Pall.: relationship with $\mathrm{H}_{2} \mathrm{O}_{2}$ production and $\mathrm{H}_{2} \mathrm{O}_{2}$-metabolizing enzyme activities. Plant Sci. 161: 125-132.

Luo Z., Wu X., Xie Y., Chen C. (2012) Alleviation of chilling injury and browning of postharvest bamboo shoot by salicylic acid treatment. Food Chemistry. 131: 456-461.

Luschin-Ebengreuth N., Zechmann B. (2016) Compartment-specific investigations of antioxidants and hydrogen peroxide in leaves of Arabidopsis thaliana during dark-induced senescence. Acta Physiol. Plant. 38: 1-15.

Lutts S., Hausman J.F., Quinet M., Lefèvre I. (2013) Polyamines and their roles in the alleviation of ion toxicities in plants. Ecophysiology and Responses of Plants under Salt Stress, Vol.12, eds P. Ahmad, M. M. Azooz, and M. N. V. Prasad (New York, NY: Springer). 315.353.

Magalhaes J.R., Monte D.C., Durzan D. (2000) Nitric oxide and ethylene emission in Arabidopsis thaliana. Physiology and Molecular Biology of Plants. 6: 117-127.

Mandal S., Mallick N., Mitra A. (2009) Salicylic acid-induced resistance to Fusarium oxysporum f. sp. lycopersici in tomato. Plant Physiol. Biochem. 47: 642-649.

Manfre A., Glenn M., Nunez A., Moreau R.A., Dardick C. (2011) Light quantity and photosystem function mediate host susceptibility to Turnip mosaic virus via a salicylic acid independent mechanism. Mol. Plant Microbe Interact. 24: 315-327.

Martin-Tanguy Y. (2008) The occurrence and possible functions of hydroxycinnamoyl acid amines in plant. Plant Growth Regul. 3: 381-399. 
Mateo A., Funck D., Mühlenbock P., Kular B., Mullineaux P.M. és mtsai. (2006) Controlled levels of salicylic acid are required for optimal photosynthesis and redox homeostasis. J. Exp. Bot. 57: 17951807.

Mateo A.P. Mühlenbock C., Rustérucci, Chang C.C., Miszalski Z., Karpinska B., Parker J.E. Mullineaux P.M., Karpinski S. (2004) LESION SIMULATING DISEASE 1 is required for acclimation to conditions that promote excess excitation energy. Plant Physiol. 136: 2818-2830.

Mattoo A.K., Chung S.H., Goyal R.K., Fatima T., Solomos T., Srivastava A., Handa A.K. (2007) Overaccumulation of higher polyamines in ripening transgenic tomato fruit revives metabolic memory, upregulates anabolism-related genes, and positively impacts nutritional quality. J. AOAC Int. 90: 1456-1464.

Mehta R.A., Cassol T., Li N., Ali N., Handa A.K., Mattoo A.K. (2002) Engineered polyamine accumulation in tomato enhances phytonutrient content, juice quality, and vine life. Nat. Biotechnol. 20: 613-618.

Melo N.K.G., Bianchetti R.E., Lira B.S., Oliveira P.M.R., Zuccarelli R., Dias D.L.O., és mtsai. (2016) Nitric Oxide, Ethylene, and Auxin Cross Talk Mediates Greening and Plastid Development in Deetiolating Tomato Seedlings. Plant Physiol. 170: 2278-2294.

Meng Z., Meng Z., Zhang R., Liang C., Wan J., Wang Y., Zhai H., Guo S. (2015) Expression of the rice arginase gene OsARG in cotton influences the morphology and nitrogen transition of seedlings. PLoS One. 10: e0141530.

Mersmann S., Bourdais G., Rietz S., Robatzek S. (2010) Ethylene signaling regulates accumulation of the FLS2 receptor and is required for the oxidative burst contributing to plant immunity. Plant Physiol. 154: 391-400.

Mhamdi A., Noctor G., Baker A. (2012) Plant catalases: peroxisomal redox guardians. Archives of Biochemistry and Biophysics. 525(2): 181-194.

Mhamdi A., Queval G., Chaouch S., Vanderauwera S., Van Breusegem F., Noctor G. (2010) Catalase function in plants: a focus on Arabidopsis mutants as stress-mimic models. Journal of Experimental Botany. 61: 4194-4220.

Mhamdi A., Queval G., Chaouch S., Vanderauwera S., Van Breusegem F., Noctor G. (2010) Catalase function in plants: a focus on Arabidopsis mutants as stress-mimic models. J. Exp. Bot. 61: 41974220.

Michael T.P., McClung C.R. (2002) Phase-specific circadian clock regulatory elements in Arabidopsis. Plant Physiology. 130(2): 627-638.

Mika A., Boenisch M., Hopff D., Lüthje S. (2010) Membrane-bound guaiacol peroxidases from maize (Zea mays L.) roots are regulated by methyl jasmonate, salicylic acid, and pathogen elicitors. J. Exp. Bot. 61: 831-841.

Miller G., Schlauch K., Tam R., Cortes D., Torres M.A., Shulaev V., Dangl J.L., Mittler R. (2009) The plant NADPH oxidase RBOHD mediates rapid systemic signaling in response to diverse stimuli. Sci. Signal. 2, ra45.

Minguet E.G., Vera-Sirera F., Marina A., Carbonell J., Blazquez M.A. (2008) Evolutionary diversification in polyamine biosynthesis. Mol. Biol. Evol. 25: 2119-2128.

Mittler R., Vanderauwera S., Suzuki N., Miller G., Tognetti V.B., Vandepoele K., Gollery M., Shulaev V., Breusegem F.V. (2011) ROS signalling: the new wave? Trends in Plant Sci. 16: 300-309.

Miura K., Tada Y. (2014) Regulation of water, salinity, and cold stress responses by salicylic acid. Frontiers in Plant Science. 5: 4.

Mo H., Wang X., Zhang Y., Zhang G., Zhang J.F., Ma Z.Y. (2015) Cotton polyamine oxidase is required for spermine and camalexin signalling in the defence response to Verticillium dahliae. Plant J. 83: 962-975.

Moller I.M., Sweetlove L.J. (2010) ROS signalling - specificity is required. Trends Plant Sci. 15: 370374.

Monteiro C., Carvalho R.F., Gratão P.L., Carvalho G., Tezotto T., Medici L.O., Peres L.E.P., Azevedo R.A. (2011) Biochemical responses of the ethylene-insensitive Never ripe tomato mutant subjected to cadmium and sodium stresses. Environmental and Experimental Botany. 71: 306-320.

Montilla-Bascón G., Rubiales D., Hebelstrup K.H., Mandon J., Harren F.J.M., Cristescu S.M., Mur L.A.J., Prats E. (2017) Reduced nitric oxide levels during drought stress promote drought tolerance in barley and is associated with elevated polyamine biosynthesis. Scientific reports. 7: 13311.

Moschou P.N., Paschalidis K.A., Delis I.D., Andriopoulou A.H., Lagiotis G.D., Yakoumakis D.I., Roubelakis-Angelakis K. (2008a) Spermidine exodus and oxidation in the apoplast induced by 
abiotic stress is responsible for $\mathrm{H}_{2} \mathrm{O}_{2}$ signatures that direct tolerance responses in tobacco. The Plant Cell. 20: 1708-1724.

Moschou P.N., Sanmartin M., Andriopoulou A.H., Rojo E., Sanchez-Serrano J.J., Roubelakis-Angelakis K.A. (2008b) Bridging the gap between plant and mammalian polyamine catabolism: a novel peroxisomal polyamine oxidase responsible for a full back-conversion pathway in Arabidopsis. Plant Physiol. 147: 1845-1857.

Moschou P.N., Delis I.D., Paschalidis K.A., Roubelakis-Angelakis K.A. (2008c) Transgenic tobacco plants overexpressing polyamine oxidase are not able to cope with oxidative burst generated by abiotic factors. Physiol. Plant. 133: 140-156.

Moschou P.N., Sarris P.F., Skandalis N., Andriopoulou A.H., Paschalidis K.A., Panopoulos N.J., és mtsai. (2009) Engineered polyamine catabolism preinduces tolerance of tobacco to bacteria and oomycetes. Plant Physiol. 149: 1970-1981.

Moschou P.N., Wu J., Cona A., Tavladoraki P., Angelini R., Roubelakis-Angelakis K.A. (2012) The polyamines and their catabolic products are significant players in the turnover of nitrogenous molecules in plants. J. Exp. Bot. 63: 5003-5015.

Moschou P.N., Roubelakis-Angelakis K.A. (2014) Polyamines and programmed cell death. Journal of Experimental Botany. 65: 1285-1296.

Mostofa M.G., Yoshida N., Fujita M. (2014) Spermidine pretreatment enhances heat tolerance in rice seedlings through modulating antioxidative and glyoxalase systems. Plant Growth Regul. 73: 31-44.

Mou Z., Fan W., Dong X. (2003) Inducers of plant systemic acquired resistance regulate NPR1 function through redox changes. Cell. 113: 935-944.

Mur L.A., Prats E., Pierre S., Hall M.A., Hebelstrup K.H. (2013) Integrating nitric oxide into salicylic acid and jasmonic acid/ethylene plant defense pathways. Front. Plant Sci. 4: 215.

Mühlenbock P., Szechynska-Hebda M., Plaszczyca M, Baudo M., Mullineaux P.M. és mtsai. (2008) Chloroplast signaling and LESION SIMULATING DISEASE 1 regulate crosstalk between light acclimation and immunity in Arabidopsis. Plant Cell 20: 2339-2356.

Müller M., Munné-Bosch S., (2015) Ethylene response factors: a key regulatory hub in hormone and stress signaling. Plant Physiol. 169: 32-41.

Naconsie M., Kato K., Shoji T., Hashimoto T. (2014) Molecular evolution of N-methylputrescine oxidase in tobacco. Plant Cell Physiol. 55: 436-444.

Najami N., Janda T., Barriah W., Kayam G., Tal M., Guy M., Volokita M. (2008) Ascorbate peroxidase gene family in tomato: Its identification and characterization. Mol. Genet. Genomics. 279: 171-182.

Nambeesan S., Datsenka T., Ferruzzi M.G., Malladi A., Mattoo A.K., Handa A.K. (2010) Overexpression of yeast spermidine synthase impacts ripening, senescence and decay symptoms in tomato. Plant J. 63: 836-847.

Nanda A.K., Andrio E., Marino D., Pauly N., Dunand C. (2010) Reactive oxygen species during plantmicroorganism early interactions. J. Integr. Plant Biol. 52: 195-204.

Németh N., Janda T., Horváth E., Páldi E., Szalai G. (2002) Exogenous salicylic acid increases polyamine content but may decrease drought tolerance in maize. Plant Sci. 162: 569-574.

Noctor G., De Paepe R., Foyer C. H. (2007) Mitochondrial redox biology and homeostasis in plants. Trends Plant Sci. 12: 125-134.

O’Brien J.A., Daudi A., Finch P., Butt V.S., Whitelegge J.P., Souda P., és mtsai., (2012) A peroxidasedependent apoplastic oxidative burst in cultured Arabidopsis cells functions in MAMP-elicited defense. Plant Physiol. 158: 2013-2027.

Overmyer K., Tuominen H., Kettunen R., Betz C., Langebartels C., Sandermann H., Kangasjärvi J. (2000) Ozone-sensitive arabidopsis rcd1 mutant reveals opposite roles for ethylene and jasmonate signaling pathways in regulating superoxide-dependent cell death. Plant Cell. 12: 1849-1862.

Pál M., Horváth E., Janda T., Páldi E., Szalai G. (2005) Cadmium stimulates the accumulation of salicylic acid and its putative precursors in maize (Zea mays L.) plants. Physiol Plant. 125: 356-364.

Pál M., Szalai G., Janda T. (2015) Speculation: polyamines are important in abiotic stress signaling. Plant Sci. 237: 16-23.

Panchuk I.I., Zentgraf U., Volkov R.A. (2005) Expression of the Apx gene family during leaf senescence of Arabidopsis thaliana. Planta. 222(5): 926-932.

Papadakis A.K., Roubelakis-Angelakis K.A. (2005) Polyamines inhibit NADPH oxidase-mediated superoxide generation and putrescine prevents programmed cell death induced by polyamine oxidase-generated hydrogen peroxide. Planta. 220: 826-837. 
Park S.W., Kaimoyo E., Kumar D., Mosher S., Klessing D.F. (2007) Methyl salicylate is a critical mobile signal for plant systemic acquired resistance. Science. 318: 113-116.

Paschalidis K.A., Roubelakis-Angelakis K.A. (2005) Spatial and temporal distribution of polyamine levels and polyamine anabolism in different organs/tissues of the tobacco plant. Correlations with age, cell division/expansion, and differentiation. Plant Physiol. 138: 142-152.

Pegg A. E., Casero R.A.Jr. (2011) Current status of the polyamine research field. Methods Mol. Biol. 720: 3-35.

Peleg-Grossman S., Melamed-Book N., Cohen G., Levine A. (2010) Cytoplasmic $\mathrm{H}_{2} \mathrm{O}_{2}$ prevents translocation of NPR1 to the nucleus and inhibits the induction of PR genes in Arabidopsis. Plant Signal. Behav. 5: 1401-1406.

Pieterse C.M.J., Van der Does D., Zamioudis C., Leon-Reyes A., Van Wees S.C.M. (2012) Hormonal modulation of plant immunity. Annu. Rev. Cell Dev. Biol. 28: 489-521.

Pignocchi C., Fletcher J.M., Wilkinson J.E., Barnes J.D., Foyer C.H. (2003) The function of ascorbate oxidase in tobacco. Plant Phys. 132: 1631-1641.

Planas-Portell J., Gallart M., Tiburcio A.F., Altabella T. (2013). Copper-containing amine oxidases contribute to terminal polyamine oxidation in peroxisomes and apoplast of Arabidopsis thaliana. BMC Plant Biol. 13: 109.

Podgórska A., Burian M., Szal B. (2017) Extra-Cellular but extra-ordinarily important for cells: Apoplastic reactive oxygen species metabolism. Front. Plant Sci. 8: 1353.

Podgórska A., Ostaszewska M., Gardeström P., Rasmusson A.G., Szal B. (2015) In comparison with nitrate nutrition, ammonium nutrition increases growth of the frostbite1 Arabidopsis mutant. Plant Cell Environ. 38: 224-237.

Poór P., Gémes K., Horváth F., Szepesi Á., Simon M.L., Tari I. (2011) Salicylic acid treatment via the rooting medium interferes with stomatal response, $\mathrm{CO}_{2}$ fixation rate and carbohydrate metabolism in tomato, and decreases harmful effects of subsequent salt stress. Plant Biol. 13: 105-114.

Poór P., Kovács J., Borbély P., Takács Z., Szepesi Á., Tari I. (2015) Salt stress-induced production of reactive oxygen- and nitrogen species and cell death in the ethylene receptor mutant Never ripe and wild type tomato roots. Plant Physiology and Biochemistry. 97: 313-322.

Poór P., Kovács J., Szopkó D., Tari I. (2013) Ethylene signaling in salt stress-and salicylic acid-induced programmed cell death in tomato suspension cells. Protoplasma. 250: 273-284.

Pottosin I., Shabala S. (2014) Polyamines control of cation transport across plant membranes: implications for ion homeostasis and abiotic stress signaling. Frontiers in Plant Science. 5: 154.

Pottosin I., Velarde-Buendía A.M., Bose J., Zepeda-Jazo I., Shabala S., Dobrovinskaya O. (2014) Cross-talk between ROS and polyamines in regulation of ion transport across plasma membrane: implications for plant adaptive responses. Journal of Experimental Botany. 65: 1271-1283.

Prabhavathi V.R., és Rajam M.V. (2007) Polyamine accumulation in transgenic eggplant enhances tolerance to multiple abiotic stresses and fungal resistance. Plant Biotechnol. J. 24: 273-282.

Quinet M., Ndayiragije A., Lefevre I., Lambillotte B., DupontGillain C.C., Lutts S. (2010) Putrescine differently influences the effect of salt stress on polyamine metabolism and ethylene synthesis in rice cultivars differing in salt resistance. Journal of Experimental Botany. 61: 2719-2733.

Racchi M.L. (2013) Antioxidant defences in plants with attention to Prunus and Citrus spp. Antioxidants. 2: 340-369.

Rao M.V., Lee H.I., Davis K.R. (2002) Ozone-induced ethylene production is dependent on salicylic acid, and both salicylic acid and ethylene act in concert to regulate ozone-induced cell death. Plant J. 32: 447-456.

Rao M.V., Paliyath G., Ormrod D.P., Murr D.P., Watkins C.B. (1997) Influence of salicylic acid on $\mathrm{H}_{2} \mathrm{O}_{2}$ production, oxidative stress and $\mathrm{H}_{2} \mathrm{O}_{2}$-metabolizing enzymes. Salicylic acid-mediated oxidative damage requires $\mathrm{H}_{2} \mathrm{O}_{2}$. Plant Physiol. 115: 137-149.

Raskin I. (1992) Role of salicylic acid in plants. Annu. Rev. Plant Physiol. Plant Mol. Biol. 43: 439-463.

Roden L.C., Ingle R.A. (2009) Lights, rhythms, infection: the role of light and the circadian clock in determining the outcome of plant-pathogen interactions. Plant Cell 21: 2546-2552.

Rodrigues MA, Bianchetti RE, Freschi L. (2014) Shedding light on ethylene metabolism in higher plants. Frontiers in Plant Science. 5: 665.

Rosales E.P., Lannine M.F., Groppa M.D., és mtsai., (2012) Polyamines modulate nitrate reductase activity in wheat leaves: involvement of nitric oxide. Amino Acids. 42: 857-865.

Roussos P.A., Pontikis C.A. (2007) Changes of free; soluble conjugated and bound polyamine titers of jojoba explants under sodium chloride salinity in vitro. J. Plant Physiol. 164: 895-903. 
Rozen S., Skaletsky H.J. (2000) Primer3 on the WWW for general users and for biologist programmers. In: Krawetz S., Misener S. (szerk.) Bioinformatics Methods and Protocols: Methods in Molecular Biology. Humana Press, Totowa, NJ, pp 365-386.

Sagi M., Fluhr R. (2006) Production of reactive oxygen species by plant NADPH oxidases. Plant Physiol. 141(2): 336-340.

Sagor G.H.M., Liu T., Takahashi H., Niitsu M., Berberich T., Kusano T. (2013) Longer uncommon polyamines have a stronger defense gene-induction activity and a higher suppressing activity of Cucumber mosaic virus multiplication compared to that of spermine in Arabidopsis thaliana. Plant Cell. Rep. 32: 1477-1488.

Saha J., Brauer E.K., Sengupta A., Popescu S.C., Gupta K., Gupta B. (2015) Polyamines as redox homeostasis regulators during salt stress in plants. Frontiers in Environmental Science. 3: 21.

Sahu G.K. (2013) Salicylic Acid: Role in Plant Physiology and Stress Tolerance. In: G.R. Rout and A.B. Das (szerk.): Molecular Stress Physiology of Plants. Springer. 217-239.

Scheler C., Durner J., Astier J. (2013) Nitric oxide and reactive oxygen species in plant biotic interactions. Curr. Opin. Plant Biol. 16: 534-539.

Sequera-Mutiozabal M.I., Erban A., Kopka J, Atanasov K.E., Bastida J., Fotopoulos V., és mtsai., (2016) Global metabolic profiling of Arabidopsis polyamine oxidase 4 (AtPAO4) loss-of-function mutants exhibiting delayed dark-induced senescence. Front. Plant Sci. 7: 173.

Shapiguzov A., Vainonen J.P., Wrzaczek M., Kangasjarvi J. (2012) ROS-talk-how the apoplast, the chloroplast, and the nucleus get the message through. Front. Plant Sci. 3: 1-9.

Sharma P., Jha A.B., Dubey R.S., Pessarakli M. (2012) Reactive oxygen species, oxidative damage, and antioxidative defense mechanism in plants under stressful conditions. J. Bot. 217037

Shi H., Ye T., Chen F., Cheng Z., Wang Y., Yang P., Zhang Y., Chan Z. (2013) Manipulation of arginase expression modulates abiotic stress tolerance in Arabidopsis: effect on arginine metabolism and ROS accumulation. J. Exp. Bot. 64: 1367-1379.

Shigeoka S., Ishikawa T., Tamoi M., Miyagawa Y., Takeda T., Yabuta Y., Yoshimura K. (2002) Regulation and function of ascorbate peroxidase isoenzymes. J. Exp. Bot. 53: 1305-1319.

Shu S., Yuan L.Y., Guo S.R., Sun J., Yuan Y.H. (2013) Effects of exogenous spermine on chlorophyll fluorescence, antioxidant system and ultrastructure of chloroplasts in Cucumis sativus L. under salt stress. Plant Physiol. Bioch. 63: 209-216.

Sierla M., Rahikainen M., Salojarvi J., Kangasjarvi J., Kangasjarvi S. (2013) Apoplastic and chloroplastic redox signaling networks in plant stress responses. Antiox. Redox Sign. 18(16): 222039.

Sobieszczuk-Nowicka E., Kubala S., Zmienko A., Małecka A., Legocka J. (2016) From accumulation to degradation: reprogramming polyamine metabolism facilitates dark-induced senescence in barley leaf cells. Front. Plant Sci. 6: 1198.

Song F., Goodman R.M. (2001) Activity of nitric oxide is dependent on, but is partially required for function of salicylic acid int he signaling pathway in tobacco systemic acquired resistance. Mol. Plant-Microbe Interact. 14: 1458-1462.

Song J.T. (2006) Induction of a salicylic acid glucosyltransferase, AtSGT1, is an early disease response in Arabidopsis thaliana. Molecules and Cells. 22: 233-238.

Suzuki N., Rivero R.M., Shulaev V., Blumwald E., Mittler R. (2014) Abiotic and biotic stress combinations. New Phytol. 203: 32-43.

Szepesi Á., Csiszár J., Bajkán Sz., Gémes K., Horváth F., Erdei L., Deér A., Simon L.M., Tari I. (2005) Role of salicylic acid pre-treatment on the acclimation of tomato plants to salt- and osmotic stress. Acta Biol. Szeged. 49: 123-125.

Szepesi Á., Csiszár J., Gémes K., Horváth E., Horváth F., Simon L.M., Tari I. (2009) Salicylic acid improves acclimation to salt stress by stimulating abscisic aldehyde oxidase activity and abscisic acid accumulation, and increases $\mathrm{Na}^{+}$content in leaves without toxicity symptoms in Solanum lycopersicum L. J. Plant Physiol. 166: 914-925.

Tada Y., Spoel S.H., Pajerowska-Muhktar K., Mou Z., Song J. és mtsai. (2008) Plant immunity requires conformational changes of NPR1 via S-nitrosyltaion and thioredoxins. Science. 321: 952-956.

Takács Z., Poór P., Á Szepesi, Tari I. (2017) In vivo inhibition of polyamine oxidase by spermine analogue, MDL-72,527, in tomato exposed to sublethal and lethal salt stress. Funct. Plant Biol. 44: 480-492. 
Takács Z., Poór P., Tari I. (2016) Comparison of polyamine metabolism in tomato plants exposed to different concentrations of salicylic acid under light or dark conditions. Plant Physiol. Bioch. 108: 266-278.

Takahashi Y., Berberich T., Miyazaki A. és mtsai. (2003) Spermine signalling in tobacco: activation of mitogen-activated protein kinases by spermine is mediated through mitochondrial dysfunction. Plant J. 36: 820-829.

Takahashi Y., Cong R., Sagor G.H.M., Niitsu M., Berberich T., Kusano T. (2010) Characterization of five polyamine oxidase isoforms in Arabidopsis thaliana. Plant Cell Rep. 29: 955-965.

Takatsuji H (2014) Development of disease-resistant rice using regulatory components of induced disease resistance. Front. Plant Sci. 5: 630.

Tanou G., Molassiotis A., Diamantidis G. (2009a) Hydrogen peroxide-and nitric oxide-induced systemic antioxidant prime-like activity under $\mathrm{NaCl}$-stress and stress-free conditions in citrus plants. J. Plant Physiol. 166: 1904-1913.

Tanou G., Job C., Rajjou L., Arc E., Belghazi M., Diamantidis G., és mtsai., (2009b) Proteomics reveals the overlapping roles of hydrogen peroxide and nitric oxide in the acclimation of citrus plants to salinity. Plant J. 60: 795-804.

Tanou G., Ziogas V., Belghazi M., Christou A., Filippou P., Job D., Fotopoulos V., Molassiotis A. (2014) Polyamines reprogram oxidative and nitrosative status and the proteome of citrus plants exposed to salinity stress, Plant Cell Environ. 37: 864-885.

Tari I., Csiszár J., Gémes K., Szepesi Á. (2006) Modulation of $\mathrm{Cu}^{2+}$ accumulation by (aminoethoxyvinyl)glycine and methylglyoxal bis(guanylhydrazone), the inhibitors of stress ethylene and polyamine synthesis in wheat genotypes. Cer. Res. Commun. 34: 989-996.

Tari I., Csiszár J., Horváth E., Poór P., Takács Z., Szepesi Á. (2015) The Alleviation of the adverse effects of salt stress in the tomato plant by salicylic acid shows a time-and organ-specific antioxidant response. Acta Biol. Cracov. Bot. 57(1): 21-30.

Tari I., Csiszár J., Szalai G., Horváth F., Pécsváradi A., Kiss G., Szepesi Á., Szabó M., Erdei L. (2002) Acclimation of tomato plants to salinity stress after a salicylic acid pre-treatment. Acta Biol. Szeged. 46: 55-56.

Tavladoraki P., Cona A., Angelini R. (2016) Copper-containing amine oxidases and FAD-dependent polyamine oxidases are key players in plant tissue differentiation and organ development. Front. Plant Sci. 7: 824.

Tavladoraki P., Cona A., Federico R., Tempera G., Viceconte N., Saccoccio S., és mtsai., (2012) Polyamine catabolism: target for antiproliferative therapies in animals and stress tolerance strategies in plants. Amino Acids. 42: 411-426.

Tavladoraki P., Rossi M.N., Saccuti G., Perez-Amador M.A., Polticelli F., Angelini R., Ferderico R. (2006) Heterologous expression and biochemical characterization of a polyamine oxidase from Arabidopsis involved in polyamine back-conversion. Plant Physiol. 141: 1519-1532.

Thain S.C., Vandenbussche F., Laarhoven L.J., Dowson-Day M.J., Wang Z.Y., Tobin E.M., Harren F.J., Millar A.J., Van Der Straeten D. (2004) Circadian rhythms of ethylene emission in Arabidopsis. Plant Physiol. 136(3): 3751-61.

Thordal-Christensen H., Zhang Z., Wei Y., Collinge D.B. (1997) Subcellular localization of $\mathrm{H}_{2} \mathrm{O}_{2}$ in plants. $\mathrm{H}_{2} \mathrm{O}_{2}$ accumulation in papillae and hypersensitive response during the barley-powdery mildew interaction. Plant J. 11: 1187-1194.

Tiburcio A.F., Altabella T., Bitrián M., Alcázar R. (2014) The roles of polyamines during the lifespan of plants: from development to stress. Planta. 240: 1-18.

Tisi A., Federico R., Moreno S., Lucretti S., Moschou P.N., Roubelakis-Angelakis K.A., Angelini R., Cona A. (2011) Perturbation of polyamine catabolism can strongly affect root development and xylem differentiation. Plant Physiology. 157: 2258-2258.

Torres M.A. és Dangl J.L. (2005) Functions of the respiratory burst oxidase in biotic interactions, abiotic stress and development. Curr. Opin. Plant Biol. 8: 397-403.

Tun N.N., Santa-Catarina C., Begum T., Silveira V., Handro W., Floh E.I.S., Scherer G.F.E. (2006) Polyamines induce rapid biosynthesis of nitric oxide (NO) in Arabidopsis thaliana seedlings. Plant Cell Physiol. 47: 346-354.

Tuominen H., Overmyer K., Keinanen M., Kollist H., Kangasjärvi, J. (2004) Mutual antagonism of ethylene and jasmonic acid regulates ozone-induced spreading cell death in Arabidopsis. Plant J. 39: $59-69$. 
Urano K., Hobo T., Shinozaki K. (2005) Arabidopsis ADC genes involved in polyamine biosynthesis are essential for seed development. FEBS Lett. 579: 1557-1564.

van Aken O., van Breusegem F. (2015) Licensed to kill: mitochondria, chloroplasts, and cell death. Trends in Plant Science. 20: 754-766.

van de Poel. B., Van Der Straeten D. (2014) 1-aminocyclopropane-1-carboxylic acid (ACC) in plants: more than just the precursor of ethylene! Front. Plant Sci. 5: 1-11.

van den Burg H.A., Takken F.L.W. (2009) Does chromatin remodeling mark systemic acquired resistance? Trends Plant Sci. 14: 286-294.

van Loon L.C., Van Strien E.A. (1999) The families of pathogenesis-related proteins, their activities, and comparative analysis of PR-1 type proteins. Physiol. Mol. Plant P. 55: 85-97.

Vlot A.C., Liu P.P., Cameron R.K., és mtsai. (2008) Identification of likely orthologs of tobacco salicylic acid-binding protein 2 and their role in systemic acquired resistance in Arabidopsis thaliana. The Plant Journal 56: 445-456.

Vranová E., Inzé D., Breusegem F.V. (2002) Signal transduction during oxidative stress. J. Exp. Bot. 53: $1227-1236$.

Wallace H.M, Fraser A.V, Hughes A. (2003) A perspective of polyamine metabolism. Biochem J. 376: 1-14.

Wang F., Cui X., Sun Y., Dong C.H. (2013) Ethylene signaling and regulation in plant growth and stress responses. Plant Cell Rep. 32: 1099-1109.

Wang Y., Chen C., Loake G.J., Chu C. (2010a) Nitric oxide: promoter or suppressor of programmed cell death? Protein and Cell. 1: 133-142.

Wang H., Liang X., Huang J., Zhang D., Lu H., Liu Z., Bi Y. (2010b) Involvement of ethylene and hydrogen peroxide in induction of alternative respiratory pathway in salt-treated Arabidopsis calluses. Plant Cell Physiol. 51: 1754-1765.

Wang X., Zhang Y. (2012) Regulation of salicylic acid on polyamine synthesize under $\mathrm{NaCl}$ stress in leaves of the yali pear. Res. J. Appl. Sci. Eng. Technol. 4: 3704-3708.

Wang Z., Ma L., Zhang X., Xu L., Cao J., Jiang W. (2015) The effect of exogenous salicylic acid on antioxidant activity, bioactive compounds and antioxidant system in apricot fruit. Sci. Hortic. 181: $113-120$.

Wi S.J., Jang S.J., Park K.Y. (2010) Inhibition of biphasic ethylene production enhances tolerance to abiotic stress by reducing the accumulation of reactive oxygen species in Nicotiana tabacum. Mol. Cells. 30(1): 37-49.

Wilson I.D., Neill S.J., Hancock J.T. (2008) Nitric oxide synthesis and signalling in plants. Plant, Cell \& Environment. 31: 622-631.

Wimalasekera R., Schaarschmidt F., Angelini R., Cona A., Tavladoraki P., Scherer G. F. (2015) POLYAMINE OXIDASE2 of Arabidopsis contributes to ABA mediated plant developmental processes. Plant Physiol. Biochem. 96: 231-240.

Wimalasekera R., Tebartz F., Scherer G. (2011a) Polyamines, polyamine oxidases and nitric oxide in development, abiotic and biotic stresses. Plant Sci. 181: 593-603.

Wimalasekera R., Villar C., Begum T. és mtsai. (2011b) Copper amine oxidase1 (CuAO1) of Arabidopsis thaliana contributes to abscisic acid-and polyamine-induced nitric oxide biosynthesis and abscisic acid signal transduction. Mol. Plant. 4: 663-678.

Wohlgemuth H., Mittelstrass K., Kschieschan S., Bender J., Weigel H.J., Overmyer K., Kangasjärvi J., Sandermann H., Langebartels C. (2002) Activation of an oxidative burst is a general feature of sensitive plants exposed to the air pollutant ozone. Plant cell Environ. 25: 717-726.

Wojciechowska N., Sobieszczuk-Nowicka E., Bagniewska-Zadworna A. (2017) Plant organ senescence - regulation by manifold pathways. Plant Biology. doi: 10.1111/plb.12672.

Wu Y., Zhang D., Chu Y. J., Boyle P., Wang Y., Brindle I. D., De Luca V., Despres C. (2012) The Arabidopsis NPR1 protein is a receptor for the plant defense hormone salicylic acid. Cell Rep. 1: 639-647.

Xu S., Hu J., Li Y., Ma W., Zheng Y., Zhu S.J. (2011) Chilling tolerance in Nicotiana tabacum induced by seed priming with putrescine. Plant Growth Regul. 63: 279-290.

Yaakoubi Y., Hamdani S., Bekalé L., Carpentier R. (2014) Protective action of spermine and spermidine against photoinhibition of photosystem I in isolated thylakoid membranes. PloS One. 9: e112893. 
Yang B., Wu J., Gao F., Wang J., Su G. (2014) Polyamine-induced nitric oxide generation and its potential requirement for peroxide in suspension cells of soybean cotyledon node callus. Plant Physiol. Biochem. 79: 41-47.

Yang Y.X., Ahammed G.J., Wu C., Fan S.Y., Zhou Y.H. (2015a) Crosstalk among Jasmonate, Salicylate and Ethylene Signaling Pathways in Plant Disease and Immune Responses. Curr. Protein Pept. Sci. 16: 450-461.

Yang Y.X., Wang M.M., Yin Y.L., Onac E., Zhou G.F., Peng S., és mtsai. (2015b) RNA-seq analysis reveals the role of red light in resistance against Pseudomonas syringae pv. tomato DC3000 in tomato plants. BMC Genomics. 16: 120.

Yoda H., Hiroi Y., Sano H. (2006) Polyamine oxidase is one of the key elements for oxidative burst to induce programmed cell death in tobacco cultured cells. Plant Physiol. 142: 193-206.

Yun B.W., Feechan A., Yin M., Saidi N.B., Le Bihan T., Yu M., Moore J.W., KangJ.G., Kwon E., Spoel S.H., Pallas J.A., Loake G.J. (2011) S-nitrosylation of NADPH oxidase regulates cell death in plant immunity. Nature. 478: 264-268.

Yun B.W., Skelly M.J., Yin M., Yu M., Mun B.G., Lee S.U. és mtsai. (2016) Nitric oxide and Snitrosoglutathione function additively during plant immunity. New Phytol. 211(2): 516-526.

Zarza X., Atanasov K.E., Marco F., Arbona V., Carrasco P., Kopka J., és mtsai. (2017) Polyamine oxidase 5 loss-of-function mutations in Arabidopsis thaliana trigger metabolic and transcriptional reprogramming and promote salt stress tolerance. Plant Cell Environ. 40(4): 527-542.

Zeier J., Pink B., Mueller M.J., Berger S. (2004) Light conditions influence specific defence responses in incompatible plant-pathogen interactions: uncoupling systemic resistance from salicylic acid and PR-1 accumulation. Planta. 219: 673-683.

Zhang M., Smith J.A.C., Harberd N.P., Jiang C. (2016a) The regulatory roles of ethylene and reactive oxygen species (ROS) in plant salt stress responses. Plant molecular biology. 91(6): 651-659.

Zhang H., Li A., Zhang Z., Huang Z., Lu P., Zhang D., Liu X., Zhang Z.F., Huang R. (2016b) Ethylene response factor TERF1, regulated by ETHYLENE-INSENSITIVE3-like factors, functions in reactive oxygen species (ROS) scavenging in tobacco (Nicotiana tabacum L.). Scientific Reports. 6: 29948.

Zhang X., Shen L., Li F., Meng D., Sheng J. (2011) Methyl salicylate-induced arginine catabolism is associated with up-regulation of polyamine and nitric oxide levels and improves chilling tolerance in cherry tomato fruit. J. Agr. Food Chem. 59: 9351-9357.

Zhang Y., Zhang H., Zou Z.R., Liu Y., Hu X.H. (2015) Deciphering the protective role of spermidine against saline-alkaline stress at physiological and proteomic levels in tomato. Phytochemistry. 110: 13-21.

Zhang Z.Q., Li Q., Li Z.M. és mtsai. (2007) Dual regulation role of GH3.5 in salicylic acid and auxin signaling during Arabidopsis-Pseudomonas syringae interaction. Plant Physiol. 145: 450-464.

Zhong S., Lin Z., Grierson D. (2008) Tomato ethylene receptor-CTR interactions: visualization of NEVER-RIPE interactions with multiple CTRs at the endoplasmic reticulum. J Exp Bot 59: 965972.

Zottini M., Costa A., Michele R.D., Ruzzene M., Carimi F., Schiavo F.L. (2007) Salicylic acid activates nitric oxide synthesis in Arabidopsis. J. Exp. Bot. 58: 1397-140. 


\section{Mellékletek}

1. melléklet: A qRT-PCR-hez felhasznált oligonukleotid primer párok

\begin{tabular}{|c|c|c|c|c|}
\hline Név & Rövidítés & Azonosító & Irány & Szekvencia (5'-3') \\
\hline Arginin-dekarboxiláz & SlADC & Solyc10g054440 & $\begin{array}{l}\text { Forward: } \\
\text { Reverz: }\end{array}$ & $\begin{array}{l}\text { GCCTTTTTCAGACCTTCAG } \\
\text { TGCTCCGTATTTCACCGTTA }\end{array}$ \\
\hline Aszkorbát-peroxidáz 1 & SlAPX1 & Solyc06g005160 & $\begin{array}{l}\text { Forward: } \\
\text { Reverz: }\end{array}$ & $\begin{array}{l}\text { CTGGTGTTGTTGCTGTTGAAG } \\
\text { GCTCTGGCTTGTCCTCTCTG }\end{array}$ \\
\hline Aszkorbát-peroxidáz 2 & SIAPX2 & Solyc06g005150 & $\begin{array}{l}\text { Forward: } \\
\text { Reverz: }\end{array}$ & $\begin{array}{l}\text { CTGGTGTTGTTGCTGTTGAAG } \\
\text { GGTGGTTCTGGTTTGTCCTCT }\end{array}$ \\
\hline Diamin-oxidáz 1 & SIDAO1 & Solyc05g013440 & $\begin{array}{l}\text { Forward: } \\
\text { Reverz: }\end{array}$ & $\begin{array}{l}\text { AATACGGGTTCGGGTTACAA } \\
\text { TGCCACAAATACACCATCCATA }\end{array}$ \\
\hline Diamin-oxidáz 2 & SIDAO2 & Solyc09g075940 & $\begin{array}{l}\text { Forward: } \\
\text { Reverz: }\end{array}$ & $\begin{array}{l}\text { GTCTGGAGTGGCAGGAATAGA } \\
\text { CGGAGTTCAAAAGCATCATTG }\end{array}$ \\
\hline Elongációs factor $1 \alpha$ & SIEF1 & Solyc06g005060 & $\begin{array}{l}\text { Forward: } \\
\text { Reverz: }\end{array}$ & $\begin{array}{l}\text { GGAACTTGAGAAGGAGCCTAAG } \\
\text { CAACACCAACAGCAACAGTCT }\end{array}$ \\
\hline Kataláz 1 & SlCAT1 & Solyc12g094620 & $\begin{array}{l}\text { Forward: } \\
\text { Reverz: }\end{array}$ & $\begin{array}{l}\text { GATGATGTTTGTCTCCCAACG } \\
\text { AATGTGCTTTCCCCTCTTTGT }\end{array}$ \\
\hline Kataláz 2 & SICAT2 & Solyc02g082760 & $\begin{array}{l}\text { Forward: } \\
\text { Reverz: }\end{array}$ & $\begin{array}{l}\text { AACAACTTCCCCGTCTTCTTC } \\
\text { TTAGGATTTGGCTTCAGAGCA }\end{array}$ \\
\hline Kataláz 3 & SICAT3 & Solyc04g082460 & $\begin{array}{l}\text { Forward: } \\
\text { Reverz: }\end{array}$ & $\begin{array}{l}\text { CCCTATTCCTCCTCGTGTCTT } \\
\text { TGTAATGTTCTCCTGGCTGCT }\end{array}$ \\
\hline $\begin{array}{l}\text { Mangán-szuperoxid- } \\
\text { dizmutáz }\end{array}$ & SIMnSOD & Solyc06g049080 & $\begin{array}{l}\text { Forward: } \\
\text { Reverz: }\end{array}$ & $\begin{array}{l}\text { TTCTCTTGGCTGGGCTATTG } \\
\text { AGCACCTTCTGCGTTCATCT }\end{array}$ \\
\hline Ornitin-dekarboxiláz & SIODC & Solyc04g082030 & $\begin{array}{l}\text { Forward: } \\
\text { Reverz: }\end{array}$ & $\begin{array}{l}\text { TGACTCTTTTGCCGATGATG } \\
\text { ACTTCCACGACTTCCCTGAG }\end{array}$ \\
\hline Poliamin-oxidáz 1 & SIPAO1 & Solyc01g087590 & $\begin{array}{l}\text { Forward: } \\
\text { Reverz: }\end{array}$ & $\begin{array}{l}\text { CCGTCAACTCCAAAAACACC } \\
\text { TCCTCTTTCATCAGCAACCA }\end{array}$ \\
\hline Poliamin-oxidáz 2 & SIPAO2 & Solyc07g039310 & $\begin{array}{l}\text { Forward: } \\
\text { Reverz: }\end{array}$ & $\begin{array}{l}\text { CGGAGTTCAAAAGCATCATTG } \\
\text { CCAAAAGCCCATCCATACAC }\end{array}$ \\
\hline $\begin{array}{l}\text { Réz/cink-szuperoxid- } \\
\text { dizmutáz }\end{array}$ & SlCu/ZnSOD & Solyc01g067740 & $\begin{array}{l}\text { Forward: } \\
\text { Reverz: }\end{array}$ & $\begin{array}{l}\text { CCGACAAGCAGATTCCTCTC } \\
\text { TCATGTCCTCCCTTTCCAAG }\end{array}$ \\
\hline Spermidin-szintáz & SISPDS & Solyc05g005710 & $\begin{array}{l}\text { Forward: } \\
\text { Reverz: }\end{array}$ & $\begin{array}{l}\text { CGACAGAAGAGTGACGGGATA } \\
\text { GGTGCTGGTTATTGGAGGAG }\end{array}$ \\
\hline Spermin-szintáz & SlSPMS & Solyc03g007240 & $\begin{array}{l}\text { Forward: } \\
\text { Reverz: }\end{array}$ & $\begin{array}{l}\text { GCAGCAAGGAAAAGAAATGG } \\
\text { GCAGGGAGTGGAGTCAAGAT }\end{array}$ \\
\hline Vas-szuperoxid-dizmutáz & SIFESOD & Solyc06g048410 & $\begin{array}{l}\text { Forward: } \\
\text { Reverz: }\end{array}$ & $\begin{array}{l}\text { ATCCCTCCTCCTTATCCAATG } \\
\text { GACATACGCCCTGTGATGC }\end{array}$ \\
\hline $\begin{array}{l}\text { A vizsgált } \\
\text { (http://wwW.ncbi.nlı }\end{array}$ & paradicsom & $\begin{array}{l}\text { génekre } \\
\text { Primer } 3\end{array}$ & (https:// & $\begin{array}{l}\text { olgenomics.net/) az } \\
\text { ttp://frodo.wi.mit.edu/) (Ro }\end{array}$ \\
\hline
\end{tabular}




\section{Publikációs lista}

\section{MTMT azonosító: 10039049}

\subsection{Tudományos közlemények referált folyóiratokban}

(A *-gal jelölt közlemények közvetlenül kapcsolódnak a Ph.D. értekezéshez)

* Zoltán Takács, Péter Poór, Péter Borbély, Zalán Czékus, Gabriella Szalai, Irma Tari (2018) $\mathrm{H}_{2} \mathrm{O}_{2}$ homeostasis in wild-type and ethylene-insensitive Never ripe tomato in response to salicylic acid treatment in normal photoperiod and in prolonged darkness. Plant Physiology and Biochemistry (IF: 2,724)

* Péter Poór, Attila Ördög, Zalán Czékus, Péter Borbély, Zoltán Takács, Judit Kovács, Irma Tari (2018) Regulation of the key antioxidant enzymes by developmental processes and environmental stresses in the dark. Biologia Plantarum pp 1-10. (IF: 1,551)

* Péter Poór, Zoltán Takács, Krisztina Bela, Zalán Czékus, Gabriella Szalai, Irma Tari (2017) Prolonged dark period modulates the oxidative burst and enzymatic antioxidant system in the leaves of salicylic acid-treated tomato. Journal of Plant Physiology 213: 216-226. (IF: 2,971)

Takács Z, Poór P, Szepesi Á, Tari I (2017) In vivo inhibition of polyamine oxidase by a spermine analogue MDL-72527, in tomato exposed to sublethal and lethal salt stress. Functional Plant Biology 44 (5): 480-492. (IF: 2,81)

* Zoltán Takács, Péter Poór, Irma Tari (2016) Comparison of polyamine metabolism in tomato plants exposed to different concentrations of salicylic acid under light or dark conditions. Plant Physiology and Biochemistry 108: 266-278. (IF: 2,997)

Péter Poór, Judit Kovács, Péter Borbély, Zoltán Takács, Ágnes Szepesi, Irma Tari (2015) Salt stressinduced production of reactive oxygen-and nitrogen species and cell death in the ethylene receptor mutant Never ripe and wild type tomato roots. Plant physiology and biochemistry 97: 313-322. (IF: 2,756)

Irma Tari, Jolán Csiszár, Edit Horváth, Péter Poór, Zoltán Takács, Ágnes Szepesi (2015) The alleviation of the adverse effects of salt stress in the tomato plant by salicylic acid shows a time-and organ-specific antioxidant response. Acta Biologica Cracoviensia Series Botanica 57: 1: 1-10. (IF: 0,73).

Poór Péter, Borbély Péter, Kovács Judit, Papp Anita, Szepesi Ágnes, Takács Zoltán, Tari Irma (2014) Opposite extremes in ethylene/nitric oxide ratio induce cell death in cell suspension culture and in root apices of tomato exposed to salt stress. Acta Biologica Hungarica 65:(4) pp. 428-438. (IF: 0,589)

Irma Tari, Gábor Laskay, Zoltán Takács, Péter Poór (2013) Response of Sorghum to Abiotic Stresses: A Review. Journal of Agronomy and Crop Science 4: 264-274. (IF: 2,433)

Ágnes Szepesi, Katalin Gémes, Gábor Orosz, Andrea Pető, Zoltán Takács, Mária Vorák, Irma Tari (2011) Interaction between salicylic acid and polyamines and their possible roles in tomato hardening processes. Acta Biologica Szegediensis Vol. 55 (1): 165-166.

\subsection{Könyvrészletek}

Tari Irma, Borbély Péter, Csiszár Jolán, Horváth Edit, Poór Péter, Szepesi Ágnes, Takács Zoltán (2016) Szalicilsav kémiai edzés hatása a paradicsom sóstressz toleranciájára. In: Tanulmánykötet 7. Báthory-Brassai konferencia elöadásaiból 2. kötet. Szerkesztők: Prof. Dr. Rajnai Zoltán Dr. Fregán Beatrix Marosné Kuna Zsuzsanna. Felelős kiadó: Az Óbudai Egyetem kiadványa, Budapest, Magyarország. ISBN 978-615-5460-97-5, pp. 411-419. 
Tari I, Borbély P, Csiszár J, Gémes K, Horváth E, Kovács J, Poór P, Szepesi Á, Takács Z (2014) Sóstressz tolerancia fokozása szalicilsavval paradicsomban: az abszcizinsav szerepe. In: Fodor Ferenc Paál Árpádtól a molekuláris növénybiológiáig. Tudományos ülés Paál Árpád születésének 125. és intézetigazgatói kinevezésének 85. évfordulója alkalmából. Budapest, Magyarország. Felelős Kiadó: ELTE TTK Biológiai Intézet, Növényélettani és Molekuláris Növénybiológiai Tanszék EFO Nyomda Százhalombatta, pp. 55-59.

\subsection{Konferencia elöadások}

Poór Péter, Takács Zoltán, Borbély Péter, Czékus Zalán, Ördög Attila, Szalai Gabriella, Tari Irma (2017) Szalicilsav kezelést követő etilénfüggő változások paradicsom növények $\mathrm{H}_{2} \mathrm{O}_{2}$ homeosztázisában fényben és sötétben. A Magyar Növénybiológiai Társaság XII. Kongresszusa. Szeged, Magyarország, 30.08-01.09.2017. p. 11.

Borbély Péter, Takács Zoltán, Csíkos Orsolya, Poór Péter, Tari Irma (2017) Exogenous ACC treatment affects photosynthetic activity and related parameters of tomato plants in a concentration dependent manner. A Magyar Növénybiológiai Társaság XII. Kongresszusa. Szeged, Magyarország, 30.0801.09.2017. p. 43.

Czékus Z, Csíkos O, Takács Z, Ördög A, Bódi N, Bagyánszki M, Tari I, Poór P (2017) Szalicilsav okozta ER stressz hatásának vizsgálata paradicsomban. A Magyar Növénybiológiai Társaság XII. Kongresszusa. Szeged, Magyarország, 30.08-01.09.2017. p. 44.

Poór Péter, Czékus Zalán, Borbély Péter, Takács Zoltán, Tari Irma (2017) Növényi antioxidáns enzimek szalicilsav kezelést követő etilénfüggő szabályozása sötétben. Magyar Szabadgyök-Kutató Társaság IX. Kongresszusa és az MTA ÉKB Mikroelem Munkabizottságának Tudományos Ülése. Gödöllö, Magyarország. 25-26.08.2017. p. 15.

Czékus Zalán, Csíkos Orsolya, Takács Zoltán, Ördög Attila, Bódi Nikolett, Bagyánszki Mária, Tari Irma, Poór Péter (2017) Szalicilsav indukálta ER stressz vizsgálata paradicsom növényekben. $X V$. Magyar Növényanatómiai Szimpózium. Budapest, Magyarország, 07.09. 2017. p. 28.

Péter Poór, Zoltán Takács, Péter Borbély, Zalán Czékus, Irma Tari (2017) Ethylene dependent changes in hydrogen-peroxide homeostasis after salicylic acid treatment in tomato. International Conference Plant Molecular Physiology. Bécs, Ausztria, 23-24 Feb. 2017. p. 21.

Zoltán Takács, Zalán Czékus, Péter Poór, Irma Tari (2016) Effect of light on the salicylic-induced oxidative stress in tomato. Closing Conference of Hungary-Serbia IPA Cross-border Co-operation Programme HUSRB/1203/221/173 „PLANTTRAIN” 23-24 May, 2016, Novi Sad, Serbia

Péter Poór, Kovács J, Szepesi Á, Borbély P, Patyi G, Takács Z, Tari I (2016) Salt stress-induced oxidative stress in ethylene signaling mutant, Never ripe tomato. Closing Conference of HungarySerbia IPA Cross-border Co-operation Programme. HUSRB/1203/221/173 „PLANTTRAIN”. 23-24 May, 2016, Novi Sad, Serbia

Zoltán Takács (2016) Effect of the light and dark conditions on the salicylic acid-induced oxidative stress. Conference of the doctoral school in biology. 17-18 May, 2016. Szeged, Hungary

Poór Péter, Németh Edit, Patyi Gábor, Czékus Zalán, Takács Zoltán, Szepesi Ágnes, Tari Irma (2015) Fény és sötét által szabályozott oxidatív robbanás és antioxidáns rendszer szalicilsav kezelt paradicsom levelekben. A Magyar Szabadgyök-Kutató Társaság VIII. Kongresszusa: Budapest, 2015. november 5-6.

Takács Zoltán, Poór Péter, Szepesi Ágnes, Tari Irma (2015) Exogén szalicilsav kezelés fényfüggő hatása a poliaminokra és katabolizmusukra paradicsom növények levelében. A Magyar SzabadgyökKutató Társaság VIII. Kongresszusa: Budapest, 2015. november 5-6

Tari Irma, Kovács Judit, Borbély Péter, Takács Zoltán, Szepesi Ágnes, Poór Péter (2015) Sóstressz indukált változások a reaktív oxigén és nitrogénformák akkumulációjában etilénreceptor mutáns Never ripe és vad típusú paradicsomban. A Magyar Szabadgyök-Kutató Társaság VIII. Kongresszusa: Budapest, 2015. november 5-6.

Zoltán Takács, Péter Poór, Ágnes Szepesi, Irma Tari (2015) Comparision of the time-dependent role of polyamine oxidases under sublethal and lethal salt stress in tomato plants. Opening Conference of Hungary-Serbia IPA Cross-border Co-operation Programme, HUSRB/1203/221/173 „PLANTTRAIN”. 20-21 April 2015. Szeged, Hungary

Ágnes Szepesi, Péter Borbély, Ágnes Hurton, Zoltán Takács, Szabolcs Tóth, Izabella Kovács, Christian Lindermayr, Irma Tari (2015) Polyamine catabolism under salt stress: Inhibiting diamine 
oxidase by aminoguanidine. Opening Conference of Hungary-Serbia IPA Cross-border Cooperation Programme, HUSRB/1203/221/173 „PLANTTRAIN”. 20-21 April 2015. Szeged, Hungary

Tari Irma, Csiszár Jolán, Horváth Edit, Poór Péter, Szepesi Ágnes, Takács Zoltán (2014) Sóstressz tolerancia fokozása szalicilsavval paradicsom növényekben. Emlékülés Paál Árpád születésének 125. és intézetigazgatói kinevezésének 85. évfordulója alkalmából, 2014. december 16., ELTE, Budapest

Poór Péter, Kovács Judit, Borbély Péter Gábor, Takács Zoltán, Szepesi Ágnes, Tari Irma (2014) Exogén NO hatása a sóstressz indukált fiziológiai válaszreakciókra paradicsomban. Magyar Tudomány Ünnepe, Az MTA SZAB Biológiai Szakbizottság ünnepi tudományos ülése, Reprezentatív elöadások a biológiai munkabizottságok kutatási területeiről, 2014. november 26.

Zoltán Takács; Péter Poór; Ágnes Szepesi; Irma Tari (2014) Role of polyamine catabolism in salt stress acclimation of tomato plants. $11^{\text {th }}$ Congress of the Hungarian Society of Plant Biology. 27-29 August 2014; Szeged; Hungary

Zoltán Takács, Ágnes Gallé, Ágnes Szepesi, Péter Poór, Irma Tari (2014) The role of polyamine catabolism associated hydrogen peroxide and nitric oxide production in salt stress-induced cell death in tomato plants. $8^{\text {th }}$ Scandinavian Plant Physiology Society PhD Students Conference. June 16-19 ${ }^{\text {th }}$, 2014, Uppsala, Sweden

Ágnes Szepesi, Péter Poór, Attila Ördög, Zoltán Takács, Irma Tari, Mária Torma, Gábor Pálfay (2014) Effect of nitric oxide-generating fungicide ingredient pyraclostrobin on abiotic stress responses of maize. Top Science Conference AgCelence in Corn. February 25-26 ${ }^{\text {th }}$, 2014, Prague, Czech Republic

Takács Zoltán, Gallé Ágnes, Kovács Judit, Poór Péter, Szepesi Ágnes, Tari Irma (2013) A poliamin katabolizmus só-stresszben betöltött szerepének tanulmányozása, egy specifikus PAO gátlószer az MDL72527 hatására, paradicsom növényekben. Magyar Tudomány Ünnepe 2013, MTA SZAB Biológiai Szakbizottság ünnepi ülése II. 2013. november 19, Szeged

Szepesi Ấgnes, Borbély Péter, Gellert Attila, Hurton Ágnes, Kovács Judit, Poór Péter, Takács Zoltán, Tóth Szabolcs, Tari Irma (2013) Az aminoguanidin hatása sóstressznek kitett paradicsom növények poliamin katabolizmusára. Magyar Tudomány Ünnepe 2013, MTA SZAB Biológiai Szakbizottság ünnepi ülése II. 2013. november 19, Szeged

Takács Zoltán, Gallé Ágnes, Kovács Judit, Poór Péter, Szepesi Ágnes, Tari Irma (2013) A poliamin katabolizmus só-stresszben és programozott sejthalálban betöltött szerepének tanulmányozása, paradicsom növényekben. A Magyar Szabadgyök-Kutató Társaság VII. Kongresszusa. 2013. augusztus 29-31, Debrecen, p. 39.

Szepesi Ágnes, Kovács Judit, Poór Péter, Takács Zoltán, Tóth Szabolcs, Marléne Delauney, Tari Irma (2013) Egy diamin-oxidáz gátlószer; az aminoguanidin hatása paradicsom növények sóstressz toleranciájára. A Magyar Szabadgyök-Kutató Társaság VII. Kongresszusa. 2013. augusztus 29-31, Debrecen, p. 38.

Takács Zoltán, Szepesi Ágnes, Tari Irma (2013) A poliamin katabolizmussal kapcsolt hidrogénperoxid és nitrogén-monoxid szerepe a só-stressz indukálta sejthalál kiváltásában, paradicsom növényekben. Sófi József ösztöndíj pályázati konferencia. 2013. március 21, Szeged. Elért helyezés: II. hely

Takács Zoltán, Szepesi Ágnes, Tari Irma (2013) A poliamin katabolizmussal kapcsolt hidrogénperoxid és nitrogén-monoxid szerepe a só-stressz indukálta sejthalál kiváltásában, paradicsom növényekben. A Magyar Növénybiológiai Társaság Fiatal Növénybiológusok Elöadássorozata. 2013. január 25; Szeged. Elért helyezés: III. hely.

Szepesi Ấgnes, Gémes Katalin, Poór Péter, Orosz Gábor, Takács Zoltán, Tari Irma (2011) Szalicilsav elökezelt paradicsom növények antioxidáns válaszai só-stressz alatt. A Magyar szabadgyök-kutató társaság VI. kongresszusa és az MTA mikroelem munkabizottságának tudományos ülése. 2011. május 27-28; Gödöllő.

Ágnes Szepesi, Jolán Csiszár, Katalin Gémes, Gábor Orosz, Péter Poór, Zoltán Takács, Irma Tari (2010) Oxidative stress responses of salicylic acid pre-treated tomato plants during salt stress. 11th International Symposium Interdisciplinary Regional Research. October 13-15, 2010; p. 30. Szeged, Hungary 


\subsection{Konferencia-kiadványok, poszterek}

Krisztina Bela, Edit Horváth, Ágnes Hurton, Riyazuddin, Zoltán Takács, Sajid Ali Khan Bangash, Jolán Csiszár (2017) Investigation of Arabidopsis thaliana glutathione peroxidase-like enzymes. New Phytologist next generation scientists: Programme, abstracts and participants. Norwich, Egyesült Királyság / Anglia, 24-26. July 2017. p. 34.

Badics Eszter, Gubala Dorottya, Szegő Anita, Gáspár László, Takács Zoltán, Papp István, Kissné Bába Erzsébet (2017) Szárazságstressz indukálta dehidrin fehérjék és gének azonosítása uborkában. XXIII. Növénynemesítési Tudományos Nap. 2017. 03. 07. Magyar Tudományos Akadémia Budapest, Magyarország

Péter Poór; Zoltán Takács; Péter Borbély; Zalán Czékus; Gábor Patyi; Irma Tari (2016) Involvement of ethylene in hydrogen-peroxide metabolism in the leaves of salicylic-acid treated tomato. Plant Biology Europe EPSO/FESPB 2016 Congress. June 26-30, 2016, Prague, Czech Republic

Krisztina Bela; Edit Horváth; Ágnes Hurton; Riyazuddin; Zoltán Takács; Hajnalka Kovács; Sajid Ali Khan Bangash; Safira Attacha; Andreas Meyer; Jolán Csiszár. (2016) The role of the Arabidopsis thaliana glutathione peroxidases under stress conditions. Plant Biology Europe EPSO/FESPB 2016 Congress. June 26-30, 2016, Prague, Czech Republic

Poór Péter, Takács Zoltán, Nagy Bence, Kecskeméti Anna, Tari Irma (2016) Salicylic acid induced hydrogen-peroxide metabolism in ethylene-insensitive Never ripe tomato mutant. A fiatal Biotechnológusok II Országos Konferenciája (FIBOK, 2016). 2016. 03. 21-22, Gödöllö.

Péter Poór; Zalán Czékus; Gábor Patyi; Péter Borbély; Judit Kovács; Zoltán Takács; Irma Tari. (2016) Investigation of salt stress induced changes in water status, photosynthetic parameters and cystein protease activity in wild type and abscisic acid-deficient sitiens mutant of tomato (Solanum lycopersicum cv.Rheinland Ruhra). Plant model species fundamentals and applications. February 04-05, 2016, Wien, Austria

Zoltán Takács, Péter Poór, Krisztina Bela, Ágnes Szepesi, Irma Tari (2015) Comparision of exogenous salicylic acid-induced polyamine catabolism in the presence of light or in darkness in tomato leaf. 12th International Conference on reactive oxygen and nitrogen specis in plants: from model systems to field. June 24-26, 2015, p. 105; Verona, Italy

Péter Poór, Zoltán Takács, Péter Borbély, Ágnes Szepesi, Irma Tari (2015) Light and darkness modulate the oxidative burst and enzymatic antioxidant systems in salicylic acid-treated tomato leaf. 12th International Conference on reactive oxygen and nitrogen specis in plants: from model systems to field. June 24-26, 2015, p. 105; Verona, Italy

Ágnes Szepesi; Péter Borbély; Attila Gellert; Ágnes Hurton; Judit Kovács; Péter Poór; Zoltán Takács; Irma Tari (2014) Short term analysis of salt stress induced polyamine catabolism affected by aminoguanidine and diphenylene iodonium iodide in tomato. $11^{\text {th }}$ Congress of the Hungarian Society of Plant Biology. 27-29 August 2014; Szeged; Hungary

Péter Poór; Ágnes Gallé; Judit Kovács; Zoltán Takács; Péter Borbély; Gábor Patyi; Sengnirane Chounramany; Ágnes Szepesi; Irma Tari (2014) Analysis of light dependent cis-regulatory elements of hexokinase genes in tomato (Solanum lycopersicum). $11^{\text {th }}$ Congress of the Hungarian Society of Plant Biology. 27-29 August 2014; Szeged; Hungary

Péter Borbély; Péter Poór; Judit Kovács; Zoltán Takács; Gábor Patyi; Ágnes Szepesi; Irma Tari (2014) Exogenous sodium nitroprussde alleviates salt-induced changes in photosynthesis of tomato leaves. $11^{\text {th }}$ Congress of the Hungarian Society of Plant Biology. 27-29 August 2014; Szeged; Hungary

Judit Kovács; Péter Poór; Gábor Patyi; Péter Borbély; Ágnes Szepesi; Zoltán Takács; Irma Tari (2014) Investigation of salt stress induced changes in cysteine protease activity in abscisic acid-deficient sitiens tomato (Solanum lycopersicum) mutant. $11^{\text {th }}$ Congress of the Hungarian Society of Plant Biology. 27-29 August 2014; Szeged; Hungary

Ágnes Szepesi; Péter Borbély; Attila Gellert; Ágnes Hurton; Judit Kovács; Péter Poór; Zoltán Takács; Irma Tari (2014) Impact of aminoguanidine on NO content and polyamine catabolism in salicylic acid treated tomato plants. 5th Plant NO Club Meeting. July; 24-25, 2014 München, Germany

Ágnes Szepesi; Attila Gellert; Ágnes Hurton; Péter Borbély; Judit Kovács; Péter Poór; Zoltán Takács; Irma Tari (2014) Effect of aminoguanidine on polyamine catabolism of tomato plants during shortterm salt stress. Oxizymes 2014. July; 01-04. 2014, Vienna; Austria 
Ágnes Szepesi, Péter Borbély, Judit Kovács, Péter Poór, Szabolcs Tóth, Zoltán Takács, Irma Tari (2013) Polyamine catabolism in tomato leaves exposed to salt stress. $6^{\text {th }}$ European Workshop on Leaf Senescence. October 14-18, 2013; p. 180. Versailles, France

Ágnes Szepesi, Péter Poór, Judit Kovács, Zoltán Takács, Ágnes Gallé, Irma Tari (2013) Effects of salicilyc acid on polyamine metabolism in tomato plants. Plant Diseases and Resistance Mechanism. February 20-22, 2013; p. 68. Vienna, Austria

Péter Poór; Ágnes Szepesi; Zoltán Takács; Judit Kovács; Irma Tari (2012) Polyamine metabolism under salt-induced cell death in tomato plants. Plant Biology Congress, 29 July- 3 August, 2012; p. 408. Freiburg, Germany

Szepesi Ágnes, Péter Poór, Kovács Judit, Takács Zoltán, Gallé Ágnes, Tari Irma (2012) Short therm effect of salicylic acid on polyamine metabolism in tomato plants. Plant Biology Congress, 29 July3 August, 2012; p. 792. Freiburg, Germany

Szepesi Ágnes; Gémes Katalin; Orosz Gábor; Pető Andrea; Takács Zoltán; Vorák Mária; Tari Irma (2011) A poliaminok mennyiségi és minőségi változása paradicsomban szalicilsav kezelés hatására és lehetséges szerepe a stresszrezisztencia fokozásában. A Magyar Növénybiológiai Társaság X. Kongresszusa. 2011. augusztus 31 - szeptember 2; Szeged.

Ágnes Szepesi, Katalin Gémes, Zoltán Takács, Gábor Orosz, Mária Vorák, Péter Poór, Irma Tari (2011) The role of polyamines and their metabolism in the regulation of $\mathrm{H}_{2} \mathrm{O}_{2}$ level in salicylic acid treated tomato plants. 10th International Conference on Reactive Oxygen and Nitrogen Species in Plants. July 5-8, 2011; p. 68. Budapest, Hungary 


\section{Köszönetnyilvánítás}

Mindenekelőtt hálás köszönettel tartozom témavezetőimnek, Dr. Tari Irmának és Dr. Poór Péternek, akik kitartó és inspiráló munkájukkal mindig támogatták és irányították szakmai fejlődésem, és akik nélkül a dolgozatom és közös publikációink nem jöhettek volna létre.

Hálásan köszönöm a tanszéken müködő „PMCS csoport” korábbi és jelenlegi tagjainak, főképpen Dr. Szepesi Ágnesnek, Dr. Kovács Juditnak, Borbély Péternek, Czékus Zalánnak, akik sokszor éjszakába nyúló munkájukkal rengeteg segítséget nyújtottak a kísérletek elvégzése és értékelése során.

Köszönettel tartozom Professzor Dr. Szalai Gabriellának, valamint az MTA ATK Növényélettani osztály valamennyi munkatársának a szalicilsav tartalmakkal kapcsolatos mérések elvégzéséért.

Hálás köszönet illeti Bécsné Kozma Etelkát, Kapásné Török Évát, Porkóláb Erzsébetet, Tandari Máriát akik nélkülözhetetlen segítségükkel és állandó odaadásukkal segítették a minták elökészítését és feldolgozását. Továbbá gondoskodásukkal, önzetlen szeretetükkel támogatták nemcsak a PhD-s éveimet, hanem a BSc-n és MSc-n tölött időszakokat is.

Hálás köszönet illeti Bela Krisztinát, Németh Editet, akik rengeteg segítséget, támogatást és bátorítást nyújtottak a sokszor nem könnyü időszakokban is.

Köszönettel tartozom Orosz Gábornak, legjobb barátomnak, egykori volt kollégámnak, akinek a segítsége, baráti támogatása nélkülözhetetlen volt egyetemi éveim során.

Köszönöm a dolgozatban felhasznált módszerekkel kapcsolatos hasznos tanácsait és kimagasló segítségét Dr. Gallé Ágnesnek, Dr. Horváth Editnek, valamint a Növénybiológiai Tanszék minden volt és jelenlegi munkatársának, aki hozzájárulásával segítette a munkámat.

Végül, de nem utolsó sorban köszönöm családomnak és barátaimnak, akik folyamatosan támogattak, és így lehetővé tették, hogy elkészüljön a dolgozatom.

A dolgozat megvalósításához hozzájárult az OTKA K101243, az OTKA PD112855, HUSRB/120/221/173 PLANTTRAIN IPA pályázatok, valamint az Emberi Erőforrások Minisztiériuma által hirdetett Nemzet Fiatal Tehetségeiért Ösztöndíj, NTP-NFTÖ-16-0596 számú pályázati forrás.
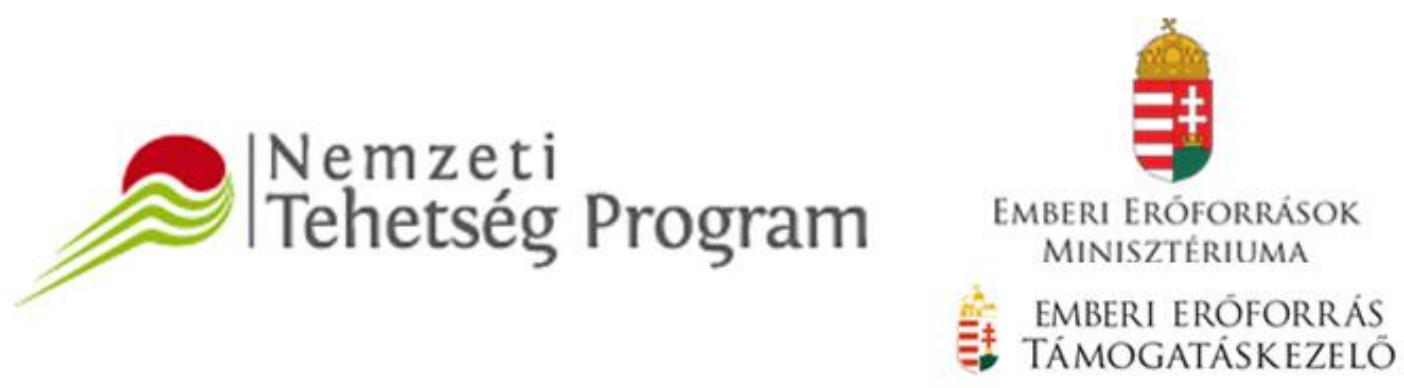


\section{Nyillatkozat}

Alulírottak kijelentik, hogy Takács Zoltán doktorjelölttel társszerzöként közösen publikált eredményeket (Plant Physiology and Biochemistry, 2018; Journal of Plant Physiology 213: 216-226, 2017) a doktorjelölt szabadon felhasználhatja a Szegedi Tudományegyetemre benyújtott doktori (Ph.D.) értekezésében. Kijelentjük, hogy ezek az eredmények más Ph.D. értekezés tudományos eredményei között nem szerepelnek. Tudomásul vesszük továbbá, hogy ezek a fent említett eredmények a jövőben nem szerepelhetnek más Ph.D. értekezés eredményei között.

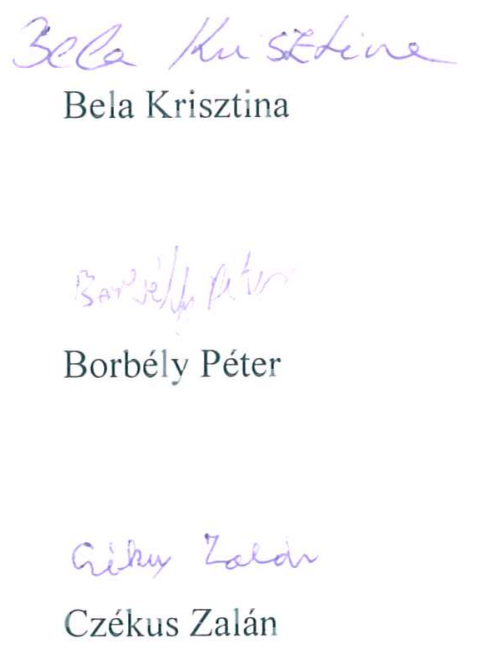

Szeged, 2018. február 26. 